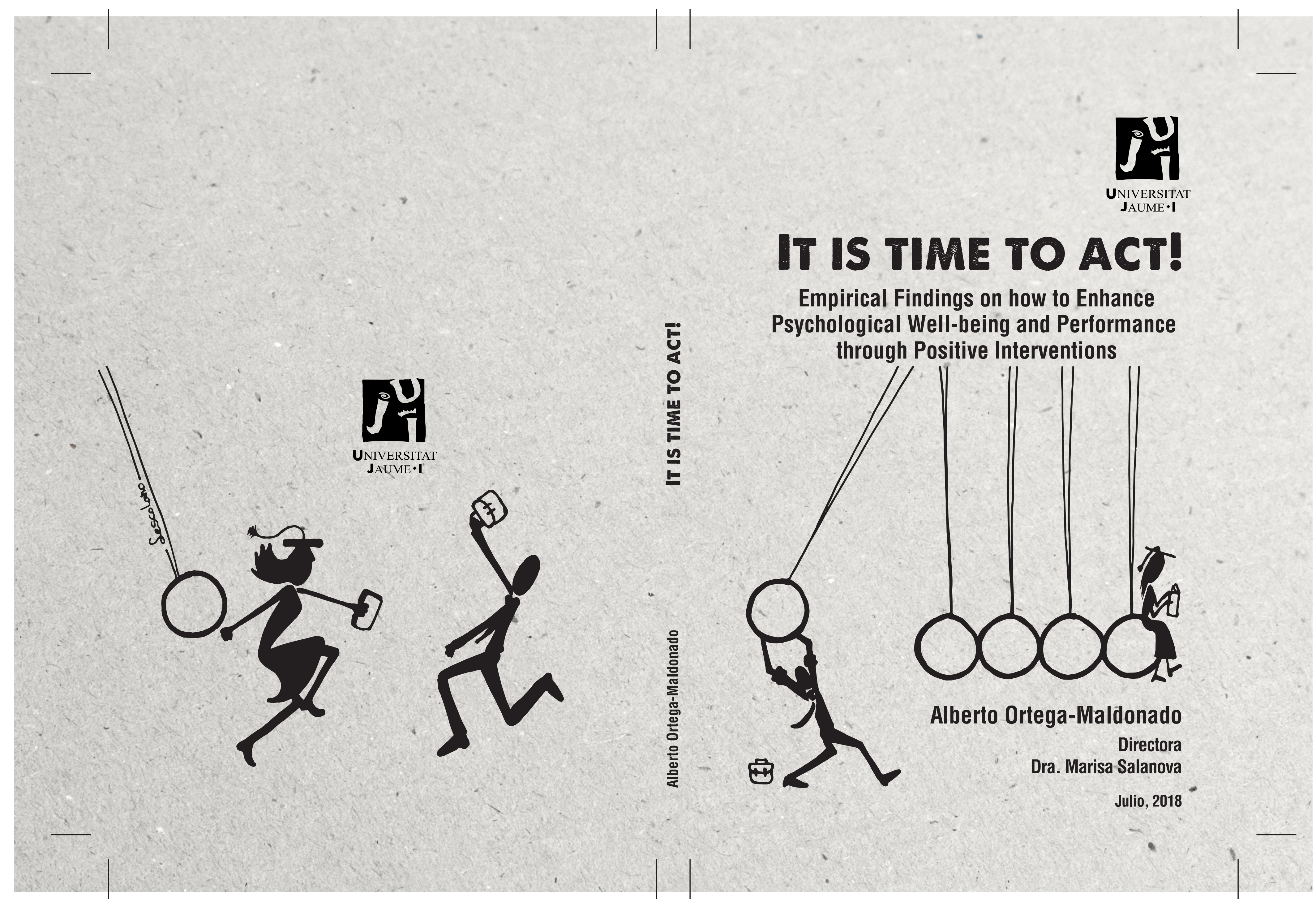


It is time to act! Empirical Findings on how to Enhance Psychological Well-being and Performance through Positive Interventions

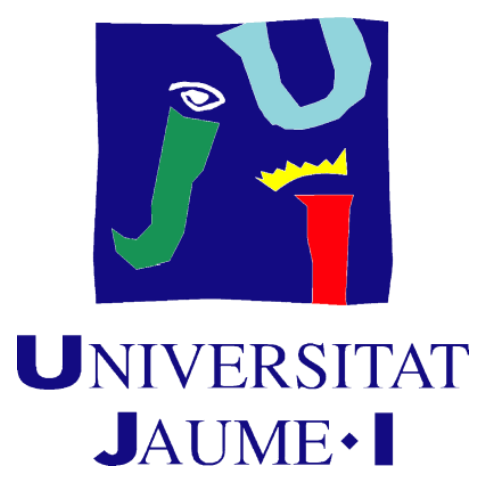

PhD Candidate: Alberto Ortega Maldonado

Supervisor and advisor: Dr. Marisa Salanova Soria July 2018 


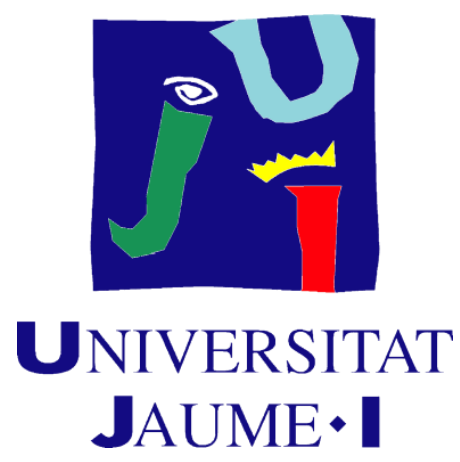

Programa de Doctorado en Psicología

Escuela de Doctorado de la Universitat Jaume I

It is time to act! Empirical Findings on how to Enhance Psychological Well-being and Performance through Positive Interventions

¡Es tiempo de actuar! Hallazgos Empíricos sobre cómo Incrementar el Bienestar Psicológico y el Desempeño mediante Intervenciones Positivas

Memoria presentada por Alberto Ortega Maldonado para optar al grado de doctor por la Universitat Jaume I
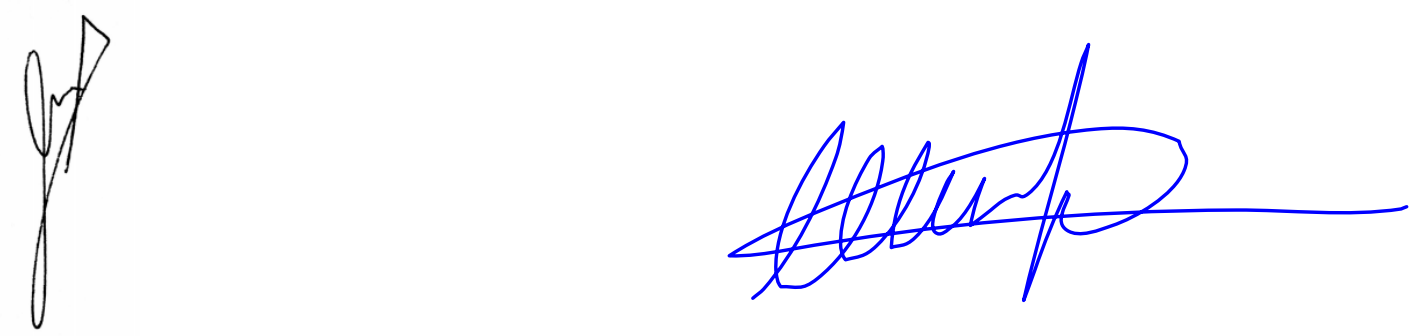

Castellón de la Plana, junio de 2018 


\section{Financiación recibida}

La realización de la presente tesis doctoral ha sido posible gracias a

\section{La Conselleria d’Educació, Formació i Ocupació de la Generalitat}

Valenciana y su financiación de un contrato de investigador en formación en el proyecto PROMETEO/2013/025 "Psicología Positiva y Salud Ocupacional en el Trabajo y en las organizaciones".

La Fundación Balaguer Gonel Hermanos y la ayuda concedida para la realización de una estancia predoctoral en la Norwich Business School de la University of East Anglia (Reino Unido), que ha posibilitado la solicitud de la "Mención de Doctorado Internacional".

\section{(c) (1) (9)(2)}

No está permitido el uso comercial de la obra original ni de las posibles obras derivadas. La distribución debe hacerse con una licencia igual a la que regula la obra original.

The commercial use of the original work or of possible derivative works is not allowed. The distribution must be in the same terms as the original work.

https://creativecommons.org/

Cover: Laura Escolano Casado "Lescolano 
A mi tía Manuela, de quien aprendí a amar al prójimo.

A mi abuelo, que me enseñó la importancia de cultivar el saber.

“(...) Pero el camino verdadero para conseguir la felicidad pasa por hacer felices a los demás. Intentad dejar este mundo un poco mejor de como os lo encontrasteis $y$, cuando os llegue la hora de morir, podréis morir felices sintiendo que de ningún modo habréis perdido vuestro tiempo sino que habréis hecho todo lo posible. Así, estad -Siempre Listos- para vivir felices y morir felices: aferraos siempre a vuestra promesa Scout, aun cuando hayáis dejado de ser muchachos..." (Baden-Powell, "Último mensaje") 


\section{Tabla de contenido}

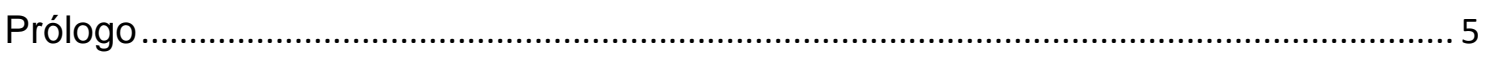

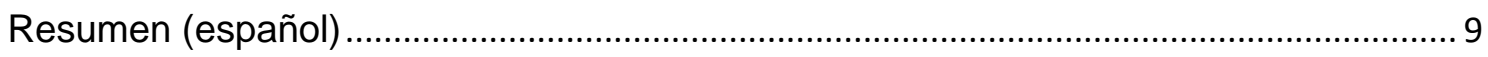

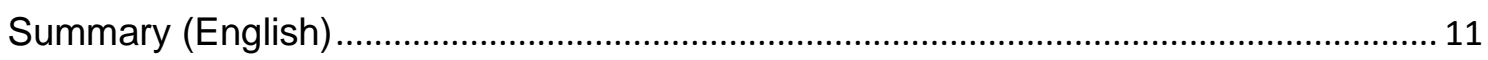

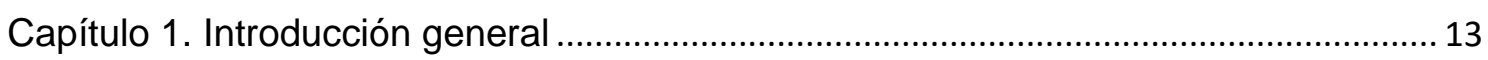

Chapter 2. Psychological Capital Interventions: An Integrative Review ......................... 37

Chapter 3. Psychological capital and performance among undergraduate students: the

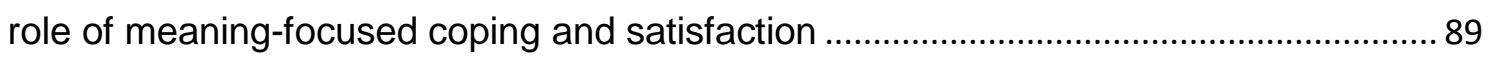

Chapter 4. A Positive Intervention to Develop Psychological Capital and Well-being: the role of Meaning-focused Coping and Daily Practice ..................................................... 111

Chapter 5. The Power of Personal Resources at Work: A Positive Psychological

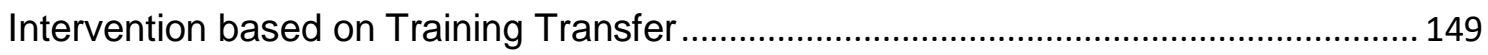

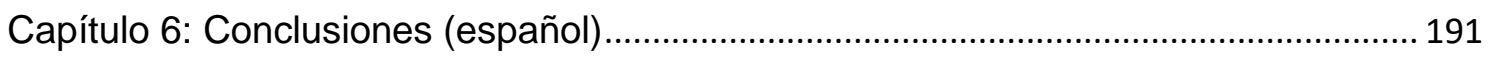

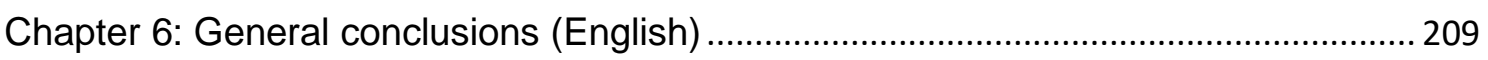

Agradecimientos 


\section{Prólogo}

Un "scout manjoniano"

Al pie de Sierra Nevada, durante mi infancia y adolescencia, me formé en dos instituciones inmersas en un modelo pedagógico basado en la educación en valores y la educación por la acción: las escuelas del Ave-María y el escultismo. Ambos movimientos educativos, nacidos durante la segunda mitad del siglo XIX, pretenden servir como escuela de ciudadanía capaz de desarrollar personas íntegras, competentes y con las habilidades y fortalezas necesarias para disfrutar de una vida plena, repleta de sentido y enfocada a la contribución al bien común.

¿Investigar? No, gracias: no es para mi

Con esta fragancia impregnada por ambos movimientos educativos desemboqué en mi formación como psicólogo. Fue entonces cuando descubrí que mi pasión y mayor motivación en la vida era ser útil a la sociedad contribuyendo al desarrollo de capacidades personales para alcanzar (lo que años más tarde aprendí que se denomina) "una vida plena". En un primer intento por poner en práctica mi objetivo vital, inicié formación y actividad en Psicología del Deporte y Psicología Social. Entendí que mi camino era el de la práctica profesional y afirmé a propios y extraños que la investigación no era algo que se ajustara a mí. Efectivamente... estaba equivocado.

De cuando me enamoré de la Psicología Positiva

Tras un breve periodo de actividad laboral en estos ámbitos de la Psicología, cercenado de forma abrupta primero por la "desaceleración económica", luego por el "crecimiento negativo" y finalmente por "vivir por encima de mis posibilidades" [nota 1: por favor, léase esta oración con el mayor tono irónico posible] [nota 2: si eres gobernante y estás leyendo esto, te aclaro que me refiero a la crisis iniciada a finales 
de la década de los 2000], decidí que era necesario para mi desarrollo profesional ampliar mi formación. Así un buen día descubrí la Psicología Positiva. El flechazo fue tan fuerte y raudo que apenas me di cuenta de lo acontecido. Una forma de entender la Psicología que a través de la evidencia científica busca el bienestar de las personas, las organizaciones y sociedades, gracias al desarrollo de sus capacidades y fortalezas. ¡Una herramienta diseñada para mí! Mi camino para dejar este mundo un poco mejor de como me lo encontré.

¿Investigar? ¡Qué buena idea!

Pero la vida no tenía tan sólo esta sorpresa para mí. La investigación, esa alternativa mal denostada y descartada en los albores de mi vida como psicólogo, iba a llamar a mi puerta. La Psicología Positiva era un manantial que apenas empezaba a brotar y, para poder beber de su fresca y reconfortante agua, era realmente necesario acudir a la fuente académica. Habría de apostar por la formación investigadora y dadas mi formación, trayectoria, intereses, motivaciones y características personales... la investigación aplicada sería el molde más acorde para mí.

\section{Afortunadamente...}

Afortunadamente, en pleno epicentro de la Psicología Positiva española, una vacante para investigar de forma aplicada había quedado desierta porque, afortunadamente, quienes se habían presentado no cumplían los requisitos preestablecidos. Afortunadamente, mi amigo Chente encontró la segunda convocatoria por internet $y$, afortunadamente, me informó de ello. Afortunadamente, fui el único candidato que cumplió todos los requisitos, y, afortu... ¿milagrosamente? acabé con mis huesos y cerebro en el Equipo WANT en la UJI. 
Soy un mutante, lo reconozco

Noviembre 2013 - Marzo 2018. Ese es mi periodo de formación en el WANT, y por tanto, ese es mi periodo de mutación y transformación. 53 meses en los que he redescubierto mi pasión, me he formado para dedicarme a ello, he investigado para contribuir al bienestar de mi comunidad, y he labrado y forjado la primera página de mi futuro. 53 meses en los que he conocido a personas maravillosas, profesionales, compañeras y amigas. 53 meses repletos de oportunidades.

53 meses,

53 peldaños,

53 recuerdos.

Afortunadamente,

53 abrazos. 


\section{Resumen (español)}

El bienestar psicológico en el trabajo ocupa actualmente un lugar importante en la agenda tanto de las administraciones públicas como de las organizaciones privadas. El desarrollo de recursos personales a través de intervenciones psicológicas positivas (IPP) es una estrategia prometedora para alcanzar niveles deseables de bienestar psicológico, pero debido al contexto socioeconómico actual, es necesario optimizar la calidad de estas intervenciones (Nielsen y Miraglia, 2017). Por este motivo, el principal objetivo de la presente tesis doctoral es profundizar en el conocimiento científico sobre el desarrollo de recursos personales en el trabajo como estrategia para incrementar el bienestar psicológico y el desempeño de las personas que conforman la organización. Para ello se plantean diferentes preguntas de investigación, con la intención de atender a necesidades tanto del ámbito de la investigación como de la actividad profesional basada en la evidencia.

1. ¿Se confirma la eficacia de las intervenciones psicológicas positivas para desarrollar recursos personales en el trabajo?

2. ¿Qué resultados positivos conlleva el desarrollo de recursos personales a través de intervenciones psicológicas positivas?

3. ¿Combinar el desarrollo de diferentes recursos personales en una intervención es una buena estrategia para optimizar la eficacia?

4. ¿La transferencia de intervención es una buena estrategia para mantener los efectos de las intervenciones dirigidas a desarrollar recursos personales?

Estas preguntas de investigación se responden a lo largo de una serie de capítulos basados en estudios empíricos y una revisión integrativa, que estudian el fenómeno tanto en el ámbito profesional con empleados y empleadas como pre-profesional con estudiantes. En primer lugar se presenta una revisión integrativa de las publicaciones sobre intervenciones para desarrollar capital psicológico (capítulo 2). Seguidamente se 
aborda un estudio empírico en el que se relaciona el capital psicológico con el afrontamiento centrado en el significado positivo de problemas, la satisfacción y el desempeño (capítulo 3). Por último se muestran dos estudios de campo en los que se evalúan intervenciones que combinan el desarrollo de los recursos de capital psicológico, el afrontamiento centrado en el significado positivo de problemas, el uso de fortalezas personales en el trabajo, y la atención plena o mindfulness (capítulos 4 y 5). Todo ello enmarcado por una introducción general (capítulo 1) y las conclusiones generales finales (capitulo 6).

Los resultados abordan tanto procesos cognitivos, como conductuales y afectivos. Mediante una metodología mixta de análisis de la información se evalúan tanto datos cuantitativos como cualitativos provenientes de diversas fuentes de información. Se emplean para ello diversas estrategias estadístico-analíticas: modelos de mediación, comparación de medias a través de pruebas $t$, análisis univariados y multivariados de la varianza (ANOVA y MANOVA) y la covarianza (ANCOVA), cálculo de modelos lineales generales (GLM) y análisis de contenido. Las principales conclusiones arrojan luz sobre la utilidad de realizar intervenciones que combinen el desarrollo de diversos recursos personales para incrementar de una forma costo-efectiva el bienestar psicológico y el desempeño en el ámbito laboral. De igual forma se revela la importancia de fomentar la transferencia de entrenamiento al trabajo diario para conseguir que los efectos de las intervenciones se mantengan de forma sostenida en el tiempo. 


\section{Summary (English)}

Today, psychological wellbeing at work occupies a central place in the agendas of public and the private organizations. A promising strategy for reaching desirable levels of psychological wellbeing involves the development of personal resources through positive psychological interventions (PPI). However, due to the current socioeconomic context, it is necessary to optimize the quality of these interventions (Nielsen \& Miraglia, 2017). For this reason, the main objective of this dissertation is to develop and broaden the scientific knowledge about personal resource development as a strategy to promote employees' psychological wellbeing and performance at work. For this purpose, some research questions are raised that address the needs of both researchers and evidence-based practitioners.

1. Is the efficacy of positive psychological interventions for developing personal resources at work confirmed?

2. What positive results does the development of personal resources through positive psychological interventions achieve?

3. Is combining the development of different personal resources through an intervention a good strategy to optimize efficacy?

4. Is the training transfer from interventions for personal resource development a good strategy to obtain sustainability?

These research questions are addressed in several chapters that include empirical studies and an integrative review and investigate the phenomena both at work and in an educational context. First, an integrative review of the research on psychological capital interventions is presented (chapter 2). Then an empirical study of psychological capital and its relationship to meaning-focused coping, satisfaction, and performance is described (chapter 3). Finally, two field studies are shown to evaluate interventions that combine the development of psychological capital, meaning-focused coping, the use of 
personal strengths at work, and mindfulness (chapters 4 and 5). All these chapters are framed by a general introduction (chapter 1) and general conclusions (chapter 6).

The main results address cognitive, behavioural, and affective processes. A mixed methodology is used to analyse both qualitative and quantitative data from different sources. Several analytical strategies are utilized: path analysis, $t$ tests, univariate and multivariate analyses of variance (ANOVA and MANOVA) and covariance (ANCOVA), general lineal models (GLM), and content analysis. The main conclusions shed light on the usefulness of conducting interventions that combine the development of different personal resources as a cost-effective strategy for promoting psychological wellbeing and performance at work. They also reveal the relevance of obtaining a training transfer to daily work life to achieve the interventions' sustainability. 


\title{
Capítulo 1. Introducción general
}

\author{
"Desechad tristezas y melancolías. \\ La vida es amable, tiene pocos días \\ y tan sólo ahora la hemos de gozar" \\ (Federico García Lorca)
}

\begin{abstract}
Así proclamó el genio de la literatura universal, invitándonos a vivir positivamente el presente de nuestras vidas. Lorca se unía así al llamamiento realizado por Aristóteles en su Libro I de "Ética a Nicómaco": "como seres humanos la felicidad es nuestra finalidad vital'. Probablemente cuando este padre del pensamiento científico escribió su célebre obra, no pudo imaginarse que la ciencia no se iba a ocupar de la investigación sobre la felicidad humana de una forma suficientemente sistemática, sostenida y sustancial, hasta prácticamente 2.350 años más tarde. Demasiado tiempo sin profundizar y cultivar en el conocimiento sobre lo que el sabio helénico denominó "el bien supremo que persigue el ser humano".
\end{abstract}

Quizá por este motivo el Doctor Martin Seligman de la Universidad de Pensilvania (EEUU), en su conocido discurso que dio pie al nacimiento de la Psicología Positiva como nuevo enfoque de investigación y práctica profesional, proclamó la imperiosa necesidad de reorientar la ciencia psicológica hacia la investigación sobre aquellos fenómenos clave para que el ser humano tenga una vida más plena y productiva. "Podemos mostrarle al mundo qué acciones conducen al bienestar, a las personas positivas, a las comunidades florecientes y a una sociedad justa (...) La psicología debería ser capaz de ayudar a documentar qué tipo de familias dan lugar a jóvenes con mejor salud, qué ambientes de trabajo apoyan la mayor 
satisfacción entre la plantilla, y qué políticas conllevan el mayor compromiso cívico" (Discurso completo en Fowler, Seligman, y Koocher, 1999).

Del discurso de Seligman se desprende un llamamiento a quienes investigaban en Psicología a profundizar sobre el funcionamiento humano óptimo en diferentes ámbitos (salud, familiar, educativo, organizacional) y a diferentes niveles (individual, grupal, social). Una de las primeras sub disciplinas en recoger este guante fue la Psicología Organizacional, del Trabajo y de los Recursos Humanos (Luthans, Youssef, y Avolio, 2007). Partiendo del hecho de que la actividad laboral ocupa tanto un papel principal como gran parte del tiempo en la vida del ser humano, varios equipos de investigación en Psicología Organizacional se pusieron manos a la obra para profundizar en aquella célebre frase atribuida a Cristóbal Colón: "Encuentra la felicidad en tu trabajo o nunca serás feliz". Así nació la Psicología Organizacional Positiva (POP), con la firme intención de estudiar bajo los sólidos parámetros del método científico el funcionamiento óptimo de las personas y los grupos en las organizaciones, profundizar en el conocimiento de la gestión efectiva del bienestar psicosocial en el trabajo y, como consecuencia de ello, desarrollar organizaciones más saludables (Salanova, Llorens, y Martínez, 2016).

Por tanto, la POP parte del concepto de salud integral aplicado al contexto específico del trabajo, entendiendo como salud "un estado de completo bienestar físico, mental y social, y no solamente la ausencia de afecciones o enfermedades" (World Health Organization, 1948). Más concretamente conceptualiza la salud mental como "un estado de bienestar en el cual el individuo es consciente de sus propias capacidades, puede afrontar las tensiones normales de la vida, puede trabajar de forma productiva y fructífera y es capaz de hacer una contribución a su comunidad" (World Health Organization, 2013). 
Tras casi dos décadas de investigación numerosas son las aportaciones en este ámbito, destacando modelos teóricos generales sobre el funcionamiento psicológico óptimo en las organizaciones, los cuales ya han acumulado suficiente sustrato empírico que confirma las hipótesis inicialmente establecidas. Así, en la actualidad conocemos que cuando estamos felices en el trabajo somos más productivos (Cropanzano y Wright, 2001), que la balanza entre recursos y demandas personales y laborales es clave para generar bienestar y excelencia organizacional (Bakker y Demerouti, 2017) y que las organizaciones más saludables son además más resilientes y consiguen mejores resultados, generando así espirales virtuosas en la dinámica organizacional (Salanova, Llorens, Cifre, y Martínez, 2012).

Uno de los temas más investigados tanto en Psicología Positiva en general como en su aplicación al ámbito organizacional, son los recursos personales y su relación con el bienestar y el desempeño, surgiendo la actividad investigadora sobre el Comportamiento Organizacional Positivo (Positive Organizational Behavior -POBoriginalmente en inglés) (Luthans et al., 2007). Esta actividad de investigación pone su foco de análisis en un doble objetivo. En primer lugar en conocer cómo los recursos personales influyen en el bienestar en el trabajo y, por consiguiente, en los niveles de excelencia en el desempeño de las tareas, los cuales repercuten en el bienestar psicológico general de las personas. En segundo lugar, en investigar acerca de cómo es posible incrementar y desarrollar estos recursos personales mediante intervenciones en el ámbito laboral (Lisbona y Salanova, 2012). En este sentido, el planteamiento ha sido (y es) diseñar, aplicar y evaluar intervenciones basadas en la evidencia que sirvan como una herramienta efectiva para mejorar la salud y bienestar de la plantilla, lo que a su vez, repercuta en su desempeño, contribuya a su estabilidad y compromiso, y además sea de utilidad para captar, potenciar y consolidar el talento. Como consecuencia de todo ello, se espera obtener una ventaja competitiva a través de un perfil de organización saludable (Le Blanc y Oerlemans, 2016; Luthans, 
Youssef-Morgan, y Avolio, 2015; Salanova et al., 2016). Por tanto se pueden considerar a la POP y la POB actividades científicas eminentemente aplicadas y volcadas de lleno en la actividad profesional, ya que su objetivo principal es mejorar la vida de las personas y las organizaciones a través de acciones e intervenciones basadas en la evidencia (Nielsen et al., 2017).

Desde sus inicios hasta nuestros días, la investigación en este ámbito ha profundizado y confirmado la relación predictiva entre los recursos personales positivos y las actitudes y los resultados saludables, habiéndose publicado varias revisiones de literatura y meta análisis que así lo avalan (Avey, Reichard, Luthans, y Mhatre, 2011; Bakker y Demerouti, 2017; Luthans y Youssef-Morgan, 2017; Nielsen et al., 2017). Sin embargo, la investigación sobre cómo desarrollar estos recursos personales en el trabajo aún es incipiente y aún existen demasiadas lagunas en el conocimiento científico al respecto (Dello Russo y Stoykova, 2015; Meyers y Van Woerkom, 2017; Van Wingerden, 2016). Tanto es así que una reciente revisión sobre investigación aplicada en el ámbito del desarrollo de recursos personales en el trabajo, ha encontrado y subrayado cierta desconexión entre la actividad investigadora académica y la práctica profesional (Tkachenko, Hahn, y Peterson, 2017), lo que pone de manifiesto que las intervenciones que se aplican en el ámbito profesional no siempre están basadas en la evidencia científica. Este distanciamiento subraya la necesidad de incrementar la investigación aplicada en el ámbito de las intervenciones para el desarrollo de recursos personales, para así contribuir desde la Academia a mejorar la calidad de la praxis profesional. Es preciso profundizar en el conocimiento sobre qué diseños, prácticas y procedimientos son más eficaces (Nielsen y Miraglia, 2017), qué efectos conllevan las intervenciones para incrementar los recursos personales y cómo de sostenibles son en el tiempo (Dello Russo y Stoykova, 2015; Meyers y Van Woerkom, 2017), y para qué poblaciones y culturas son eficaces estas intervenciones (Reichard, Dollwet, y Louw-Potgieter, 2014). 
Por otro lado la ciencia tiene entre sus funciones principales la función social. Por ello es necesario vincular al actual contexto socioeconómico toda esta necesidad de profundización en la investigación aplicada. La importante crisis económica mundial iniciada a finales de la pasada década, la revolución tecnológica, la explosión de la globalización y la transformación tanto de la comunicación como de las relaciones sociales, consolidan lo que se denomina actualmente en el ámbito político-socioeconómico "el escenario VUCA" (del inglés Volatility, Uncertainty, Complexity and Ambiguity, que significa Volatilidad, Incertidumbre, Complejidad y Ambigüedad). Es decir, actualmente las organizaciones conviven en un entorno incierto y cambiante al que deben adaptar su estrategia, planificación y funcionamiento para poder sobrevivir (Sarkar, 2016). El factor tiempo, por tanto, ha pasado a constituir uno de los mayores recursos y bienes más preciados para la organización, y la optimización de cada una de las acciones que se llevan a cabo se ha convertido en un elemento indispensable para la supervivencia. Por este motivo, la investigación aplicada al desarrollo de los recursos personales debe adaptarse a este escenario, ya que las organizaciones interesadas en incrementar los niveles de bienestar y desempeño de las personas que las componen, necesitan hacerlo de una forma costo-efectiva, para así obtener los mayores resultados con los menores recursos posibles (Luthans et al., 2015). De esta forma la investigación en el diseño, aplicación y evaluación de intervenciones debe de adaptarse a esta demanda para poder responder a la necesidad de las propias organizaciones, y de esta forma reducir la mencionada brecha existente entre Academia y profesionales (Tkachenko et al., 2017).

Por último, si bien es cierto que la Psicología Organizacional y del Trabajo persigue principalmente mejorar la vida de las personas que forman parte de las organizaciones, tampoco se debe olvidar preparar adecuadamente a las personas que formarán parte de ellas en un futuro. La actual actividad formadora en el ámbito de la educación superior pretende dotar al alumnado de las capacidades técnicas 
necesarias para realizar la actividad profesional. Ahora bien, si se concibe y se parte de la base de que las organizaciones y sus integrantes del futuro se desenvolverán en un entorno cambiante en el que los recursos personales serán clave para la supervivencia y, mejor aún, para la excelencia ¿no se debería de preocupar la Academia por desarrollar estos recursos desde la etapa formativa? Y si esto fuera así, ¿no se debería de asegurar de que las intervenciones a implantar tuvieran una base teórica y existiera una evidencia empírica al respecto?

Asumiendo estas dos cuestiones, la Psicología Organizacional y del Trabajo, por tanto, debería de ocuparse de ofrecer a quienes gestionan las instituciones superiores de enseñanza, intervenciones basadas en la evidencia que garantizaran el desarrollo de los recursos personales de su alumnado, es decir, de la futura fuerza de trabajo de nuestra sociedad. De esta forma se podría contribuir a incrementar sus niveles de recursos personales presentes y futuros, pero también se contribuiría al desempeño académico presente y desempeño laboral futuro, y por último a su bienestar psicológico y, por tanto, a la salud presente y futura. Es decir, se contribuiría a mejorar la sociedad presente y se actuaría proactivamente para mejorar la futura. Además de esto, en un mercado laboral complejo y competitivo en el que la incorporación de recién egresados es cada vez más dificultosa, el desarrollo de recursos personales podría favorecer la empleabilidad, ya que es un factor determinante para el éxito en el proceso de búsqueda de trabajo (Fugate, Kinicki, y Ashforth, 2004). Por ende, las instituciones de formación superior deberían estar social y moralmente preocupadas en complementar la educación de su alumnado no sólo con conocimientos técnicos sino también con el desarrollo de competencias y recursos personales.

Atendiendo a los retos y necesidades de investigación anteriormente mencionadas, la presente tesis doctoral pretende profundizar en el conocimiento científico sobre el desarrollo de recursos personales en el trabajo como 
estrategia organizacional para incrementar el bienestar y el desempeño de las personas que conforman la organización. Los resultados de este proyecto doctoral aspiran a servir a:

- Quienes investigan de forma aplicada en Psicología Organizacional Positiva y Comportamiento Organizacional Positivo,

- aportando evidencia sobre la relación entre recursos personales, bienestar y desempeño.

- aportando evidencia sobre intervenciones psicológicas positivas eficaces para incrementar recursos personales en el trabajo,

- aportando evidencia sobre los efectos de las intervenciones para incrementar recursos personales en el trabajo en el bienestar y desempeño.

- Quienes trabajan en el ámbito organizacional y de desarrollo de personas en el trabajo,

- aportando evidencia sobre procedimientos costo-efectivos eficaces capaces de incrementar los recursos personales de las personas con las que se interviene.

- aportando evidencia sobre procedimientos costo-efectivos eficaces capaces de incrementar el bienestar y el desempeño en las organizaciones.

- Quienes gestionan la formación de pre-profesionales, y quienes se dedican a su formación,

- aportando evidencia sobre cómo desarrollar recursos personales necesarios en la actividad formativa presente y profesional futura.

- aportando evidencia sobre cómo incrementar el bienestar y el desempeño en la actividad formativa presente y profesional futura. 


\section{La salud mental y el bienestar psicológico en el trabajo: una cuestión en la agenda social y política}

El trabajo es una actividad central en la vida. Por ello es uno de los aspectos que afecta de forma sustancial tanto a la salud física como mental de una persona, influyendo significativamente en todos los ámbitos de la vida. La Agencia Europea para la Seguridad y Salud en el Trabajo (EU-OSHA) estima que en la actualidad los problemas de salud psicosocial en el ámbito laboral como el estrés o la ansiedad, tienen un coste anual estimado en la Unión Europea (UE) de unos 20.000 millones de euros, debido tanto a la pérdida de jornadas de trabajo como a los costes sanitarios asociados (EU-OSHA, 2014). Es más, los problemas de salud psicosocial en el trabajo están asociados a un menor desempeño laboral, una mayor tasa de absentismo y presentismo y una mayor incidencia de bajas laborales, lo que se estima que tiene un coste anual para las empresas europeas de unos 1.220 euros por persona empleada (EU-OSHA, 2014). De hecho tanto el "Marco Estratégico de la UE en Materia de Salud y Seguridad en el Trabajo 2014-2020" como el "Pacto Europeo para la Salud Mental y el Bienestar", reconocen la importancia de intervenir en el ámbito laboral en el área de los factores psicosociales. Ambos documentos instan a las organizaciones a adoptar medidas voluntarias y proactivas para incrementar los niveles de bienestar psicológico de las personas que componen sus plantillas.

Desde la alta administración europea se entiende que invirtiendo en salud psicosocial en el trabajo se pueden prevenir enfermedades, limitar las bajas por enfermedad, fomentar la productividad y alargar la vida laboral, lo que puede conllevar un beneficio social y económico importante tanto para los sistemas de pensiones como de atención sanitaria. En este sentido se ha estimado que el retorno de la inversión en seguridad y salud en el trabajo puede ser de 2,2 euros por euro invertido (ISSA, 2013). Por estos motivos, tras casi dos décadas de investigación en POP, la agenda política de la UE comienza a acoger iniciativas encaminadas a fortalecer la sociedad a través del desarrollo de organizaciones saludables que fomentan personas saludables, 
estando presentes hoy en día estos temas en los foros de discusión en de la UE este campo (por ejemplo, "The Future of Occupational Safety and Health in Europe: Strengthening Social Europe through Healthier Workplaces for Safer Workers", Public Policy Exchange, 2018).

\section{Intervenciones para desarrollar recursos personales: la importancia del capital psicológico}

Una de las estrategias más prometedoras para incrementar el bienestar psicológico en el trabajo es el desarrollo de recursos personales. Cuando realizamos tareas para alcanzar nuestros objetivos laborales empleamos una serie de recursos personales que nos ayudan a desempeñarnos de forma excelente, lo que contribuye a mejorar nuestro nivel de bienestar a través del incremento de emociones positivas, el aumento de la satisfacción laboral y vital, la autorrealización y la sensación de logro, y la sensación de sentido de nuestras acciones en la vida (Luthans et al., 2015; Seligman, 2011a). Estos recursos personales que empleamos en nuestro quehacer diario varían según su perdurabilidad en el tiempo, pudiendo clasificarse en un continuo según su grado de estabilidad (ver figura 1) (Luthans et al., 2015). Así, en un extremo se sitúan las emociones positivas, que son estados poco duraderos y están estrechamente vinculados a eventos pasajeros. Por el contrario, en el otro extremo se sitúan rasgos más estables y más difíciles de modificar como las características de personalidad o la inteligencia. Pero los recursos personales de más interés y utilidad para las organizaciones son aquellos que se sitúan en la parte central del continuo, es decir, aquellos recursos próximos a los rasgos pero más fácilmente moldeables, o próximos a los estados pero menos dependientes de un evento puntual.

Próximas a los rasgos podemos encontrar las fortalezas personales (Peterson y Seligman, 2004), la atención plena o mindfulness (Bishop et al., 2004), o las habilidades de afrontamiento del estrés (Folkman, 2010). Próximos a los estados se 
encuentran los recursos estrechamente vinculados a la realización de tareas y la consecución de metas: lo que se ha venido a denominar el capital psicológico positivo (Luthans et al., 2007). Se trata de una serie de recursos como las creencias necesarias para desempeñar exitosamente tareas retadoras (Bandura, 1997), las atribuciones positivas sobre el éxito en esas tareas (Seligman, 2011b), la fuerza de voluntad para superar las posibles dificultades encontradas y la capacidad para generar estrategias de acción para solventar dichas dificultades (Snyder, 2000), y la habilidad de mantener el empeño e incluso salir fortalecido ante esas adversidades (Masten, 2001). Es decir, el capital psicológico es el resultado de la interacción de los recursos de la autoeficacia, el optimismo, la esperanza y la resiliencia. Esta interacción implica que los cuatro recursos funcionan como un recurso superior o de "segundo orden", es decir, que tienen más fuerza predictiva y explican más varianza de resultados positivos de forma conjunta que por separado (Luthans y YoussefMorgan, 2017).

Figura 1. Estabilidad de los recursos personales

\section{TIPOS DE RECURSOS PERSONALES}

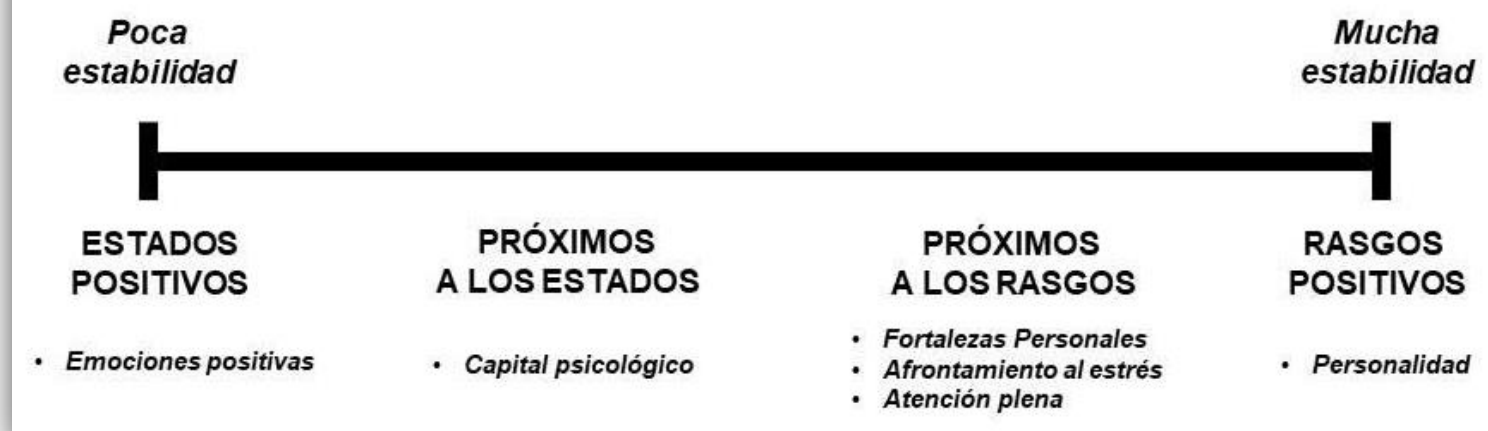

En el "escenario VUCA" el capital psicológico viene a complementar al capital humano, que se refiere al conocimiento técnico y las competencias de las personas que forman parte de una organización. Pero también en este escenario de inestabilidad e incertidumbre, el capital psicológico viene a complementar al 
denominado capital social, es decir, a la red de contactos personales y laborales de quienes componen la organización. Por tanto el capital psicológico se constituye como un agregado de capital a los activos intangibles de una organización, aportando una ventaja competitiva a través de un recurso estratégico inimitable, capaz de aportar un valor añadido de implicaciones trascendentales para la organización (Luthans et al., 2007).

Debido a su grado estabilidad y maleabilidad, una característica diferenciadora del capital psicológico respecto al resto de recursos personales es su alta capacidad de desarrollo a través de una intervención intensiva o "micro-intervención" (Luthans, Avey, Avolio, Norman, y Combs, 2006). Aunque la investigación en el desarrollo del capital psicológico está todavía en su estadio inicial, diversas publicaciones ya han demostrado que el capital psicológico se puede desarrollar a través de un taller específico de 1 a 4 horas de duración denominado "PCl" (Psychological Capital Intervention), permaneciendo activo parte del incremento obtenido incluso un mes después de la intervención (Dello Russo y Stoykova, 2015). Ésta y otra literatura relacionada con otras intervenciones dirigidas a incrementar el capital psicológico (Demerouti, Eeuwijk, Snelder, y Wild, 2011; Meyers, Van Woerkom, De Reuver, Bakk, y Oberski, 2015; Zhang, Li, Ma, Hu, y Jiang, 2014), demuestran que este recurso es desarrollable a través de metodologías intensivas. Pero la implementación de esta intervención no es una ciencia exacta y su aplicación depende de forma sustancial tanto de la motivación y realidad de la organización, como de las características personales, grupales, organizacionales, sociales y culturales que en ella se encuentran (Luthans y Youssef-Morgan, 2017). Por ello, y con la intención de optimizar al máximo la calidad de las intervenciones, es necesario todavía resolver muchas preguntas acerca de su efectividad en diferentes contextos y con diferentes perfiles (Nielsen y Miraglia, 2017). 
Existe por tanto una necesidad de profundizar en la investigación acerca de las posibles variables moduladoras y mediadores intervinientes, así como sobre los resultados positivos que la intervención conlleva tanto para las personas participantes como para las organizaciones en sí. Es preciso profundizar en el conocimiento sobre qué procedimientos son más beneficiosos y en qué condiciones. De esta manera, se podrá contribuir con la actividad profesional por un lado ofreciéndole información basada en la evidencia para tomar decisiones al diseñar y aplicar estas intervenciones. Por otro, incrementando la confianza de las organizaciones a la hora de invertir en procesos y acciones para desarrollar su capital psicológico.

\section{Dos estrategias para optimizar las intervenciones: combinación de recursos y transferencia de entrenamiento}

Recientemente varios trabajos publicados en el ámbito del desarrollo de recursos humanos han recalcado la necesidad investigar en más profundidad para comprender mejor los procesos psicológicos que sustentan las intervenciones dirigidas a incrementar recursos personales (Nielsen y Miraglia, 2017; Williams, Kern, y Waters, 2016, 2017). Según la investigación en POP los recursos personales desarrollables (ya estén próximos a estados o a rasgos) comparten antecedentes, interaccionan entre sí y están interrelacionados en su capacidad predictiva de resultados positivos como el bienestar psicológico o el desempeño (Bakker, 2013). Por este motivo, profundizar en el conocimiento sobre los procesos psicológicos subyacentes tanto en estas relaciones predictivas, como en las dinámicas propias surgidas durante su desarrollo, puede ser de gran utilidad a la hora de diseñar intervenciones combinadas. De hecho, desde modelos como la "teoría de conservación de recursos" se ha investigado que las personas que poseen recursos consolidados, no sólo tienden a conservar estos recursos y las ganancias a ellos asociadas, sino que son más capaces de desarrollar nuevos, lo que unido a las ganancias iniciales genera ganancias posteriores, desencadenando así espirales virtuosas (Hobfoll, 2002). Este 
tipo de intervenciones combinadas podrían ser, por tanto, intervenciones más eficaces y obtener mejores resultados. Es decir, podrían ser una buena herramienta para optimizar los esfuerzos realizados tanto por la organización como por quienes participan en estas acciones, obteniéndose mejores resultados en menos tiempo.

Por otra parte, se ha encontrado que la transferencia de lo aprendido a la actividad laboral diaria, es una estrategia eficaz para asegurar que los efectos de entrenamiento de habilidades para el trabajo perduren en el tiempo (Burke y Hutchins, 2007). Es decir, cuando quienes acuden a este tipo de entrenamientos aplican posteriormente el contenido aprendido a su trabajo, ese aprendizaje se consolida, lo que influye en que las nuevas habilidades adquiridas pasen a incorporarse de forma permanente al repertorio conductual del personal. Estos resultados van en sintonía con lo argumentado por la "teoría de la ampliación y construcción de recursos positivos" (Fredrickson, 2004), que sitúa las emociones positivas como un mecanismo esencial para la ampliación de repertorios cognitivos y de conducta. Así, al aplicar el contenido aprendido durante el entrenamiento, la persona mejora su desempeño, lo que le posibilita un incremento de su estado afectivo positivo que, lo cual, contribuye a consolidar tanto dicho comportamiento como los procesos cognitivos a él asociados. Teniendo en cuenta que el entrenamiento de habilidades necesarias para el desempeño laboral guarda cierta similitud con el desarrollo de recursos personales a través de intervenciones, se puede establecer un paralelismo entre la importancia de la transferencia para obtener efectos perdurables en un tipo de entrenamiento y en otro. Basándose en la propio marco establecido por Barbara Fredrickson y asumiendo además que los recursos personales son capaces de ser conservados a través de experiencias de éxito (Hobfoll, 2002), la transferencia de los repertorios conductuales asociados al desarrollo de estos recursos se plantea como un posible elemento clave para lograr sostenibilidad de los efectos tras las intervenciones. 


\section{Descripción general de la tesis}

Basada en los postulados teóricos y las evidencias empíricas comentadas en los apartados anteriores, esta tesis doctoral contiene cuatro estudios dirigidos a profundizar en el conocimiento sobre cómo se pueden optimizar las intervenciones dirigidas a desarrollar recursos personales, qué efectos en cuanto a bienestar psicológico y desempeño conllevan y cómo se pueden mantener dichos efectos a lo largo del tiempo. Específicamente y, teniendo en cuanta la necesidad de profundizar tanto en el ámbito pre-profesional como profesional, en este trabajo científico se abordan estudios en estas dos poblaciones. Las investigaciones presentadas a continuación pretenden contestar a las siguientes preguntas mostradas en la Tabla 1. 
Tabla 1. Preguntas de investigación 1

Capítulos

Pregunta 1: ¿Se confirma la eficacia de las intervenciones psicológicas positivas para desarrollar recursos personales en el trabajo?

Pregunta 1.1: ¿Incrementan los recursos intervenidos?

$x \quad x \quad x$

Pregunta 1.2: ¿Son eficaces en diferentes poblaciones?

$X \quad X \quad X$

Pregunta 1.3: ¿Existen diferencias entre diversos procedimientos de aplicación?

$X \quad X$

Pregunta 2: ¿Qué resultados positivos conlleva el desarrollo de recursos personales a través de intervenciones psicológicas positivas?

Pregunta 2.1: ¿El desarrollo de recursos personales a través de intervenciones $X \quad X$

Pregunta 2.1: ¿El desarrollo de recursos personales a través de intervenciones

$X \quad X$

Pregunta 3: ¿Combinar el desarrollo de diferentes recursos personales en una intervención es una buena estrategia para optimizar la eficacia?

Pregunta 3.1: ¿Predice la relación entre diversos recursos personales, el bienestar $X$

Pregunta 3.2: ¿Las intervenciones que combinan el desarrollo de diferentes

$X \quad X$

Pregunta 3.3: ¿Las intervenciones que combinan el desarrollo de diferentes

$X \quad X$

Pregunta 4: ¿La transferencia de intervención es una buena estrategia para mantener los efectos de las intervenciones dirigidas a desarrollar recursos personales? 


\section{Capítulo 2: Una revisión integrativa sobre las intervenciones para desarrollar el capital psicológico}

Este primer estudio tiene como objetivo revisar la literatura publicada respecto al desarrollo del capital psicológico, uno de los recursos personales relacionados con el bienestar y el desempeño en el trabajo más investigados. Las intervenciones en capital psicológico son un tema emergente relacionado con la actividad académica y profesional. En la actualidad existen diversas revisiones de la literatura que resumen la capacidad predictiva y la relación del capital psicológico respecto al bienestar y al desempeño. Sin embargo, no existen revisiones que sinteticen la investigación publicada sobre intervenciones psicológicas positivas en capital psicológico, lo que puede resultar eminentemente útil tanto para profesionales como para investigadores e investigadoras. Este capítulo pretende resolver esta cuestión mediante la revisión integrativa de trabajos científicos y profesionales, publicados y presentados a nivel internacional en diversos foros del ámbito de la Psicología del Trabajo, de las Organizaciones y de los Recursos Humanos.

Los principales resultados de los 32 trabajos revisados arrojan como conclusión que las intervenciones para desarrollar el capital psicológico son generalmente efectivas. Predominan las metodologías de micro-intervención estandarizadas sobre aquellas más extensas. Sin embargo, existen diferencias entre ambas metodologías en cuanto a efectividad y sostenibilidad de los efectos. Se detectan numerosas áreas de investigación aún por clarificar y desarrollar en pos de profundizar en el conocimiento en este ámbito. Además, se percibe la necesidad de una mayor investigación comparativa sobre diferentes estrategias empleadas, sobre los diversos resultados positivos obtenidos y efectos asociados, así como sobre las diferencias culturales existentes. Por último se detecta la presencia de intervenciones que compaginan mecanismos relacionados con el desarrollo de varios recursos 
personales, como son el afrontamiento positivo del estrés o las fortalezas personales, o la modulación y focalización de la atención.

\section{Capítulo 3: La relación entre el capital psicológico y el afrontamiento con significado positivo del estrés}

Uno de los principales resultados de la revisión expuesta en el capítulo 2 es la presencia de intervenciones que compaginan mecanismos compartidos entre el capital psicológico y las estrategias de afrontamiento del estrés centradas en el significado positivo de las adversidades. En este sentido, este capítulo explora las relaciones predictivas entre el capital psicológico, el afrontamiento centrado en el significado, la satisfacción y el desempeño en una muestra de 682 pre-profesionales, estudiantes en la universidad.

Los resultados indican la existencia de un modelo predictivo de mediación secuencial indirecta, en el que capital psicológico predice directamente el desempeño, pero también lo hace indirectamente a través de las estrategias de afrontamiento centrado en el significado y la satisfacción. Además, el capital psicológico predice directamente la satisfacción, destacando la importancia de este recurso en el proceso formativo de pre-profesionales. Comprender el papel que juegan el afrontamiento centrado en el significado y la satisfacción en la relación entre el capital psicológico y el desempeño puede ser útil para que tanto académicos como profesionales diseñen intervenciones óptimas basadas en la evidencia para aumentar tanto el bienestar como el rendimiento académico.

\section{Capítulo 4: Comprobación de la eficacia de una intervención combinada y transferida al día a día}

Este capítulo continúa con las conclusiones obtenidas en los capítulos anteriores relativas a la relación existente entre el capital psicológico y las estrategias 
de afrontamiento del estrés centradas en el significado positivo, así como con la transferencia de entrenamiento como estrategia de optimización de la intervención. De esta forma, este capítulo presenta un estudio comparativo entre los efectos en cuanto al desarrollo de recursos y al bienestar psicológico de tres procedimientos de intervención diferentes: 1) una intervención para desarrollar capital psicológico, 2) una intervención combinada para desarrollar el capital psicológico y el afrontamiento centrado en el significado, y 3) la intervención combinada de estos recursos unida a la práctica diaria durante las tres semanas posteriores. Para ello a través de un diseño cuasi experimental de evaluación pre-test, pos-test y seguimiento de 1 mes, se comparan los tres procedimientos entre sí y además con una condición control. Con un espíritu de continuidad del estudio incluido en el capítulo 3, una muestra de preprofesionales se asignó aleatoriamente a cada condición.

Los resultados del análisis multivariado de la varianza (MANOVA) muestran que la intervención combinada que incorporó práctica diaria tuvo un impacto significativo sostenido en el tiempo tanto en el desarrollo del capital psicológico como en el bienestar. Por tanto, estos resultados de este capítulo indican que la combinación de recursos personales unida a la práctica diaria después de la intervención es una estrategia útil para mantener los efectos a lo largo del tiempo tanto en el desarrollo de los recursos personales, como en la mejora del bienestar, contribuyendo así a optimizar este tipo de intervenciones en el ámbito laboral.

\section{Capítulo 5: "RP+", combinar más recursos y transferir el aprendizaje al trabajo}

Por último este capítulo sintetiza las conclusiones y resultados de todos los capítulos anteriores para explorar una intervención en recursos personales denominada "RP+" compuesta por cinco breves talleres para desarrollar capital psicológico, afrontamiento centrado en el significado, el uso de fortalezas personales y 
la atención plena como estrategia organizacional para incrementar el bienestar psicológico y el desempeño en el ámbito laboral. A raíz de un estudio de campo realizado en una empresa española $(N=35)$ del sector servicios se analiza si la participación en esta intervención combinada centrada en la transferencia contribuye a desarrollar tanto a corto como a largo plazo estos recursos personales, y conduce además a aumentar el desempeño y el bienestar psicológico.

El análisis tanto de datos cuantitativos como cualitativos revela un aumento de las variables intervenidas tanto a corto como a largo plazo. Además, los participantes informaron de comportamientos transferidos a la vida diaria en el trabajo, lo que constata la efectividad de dicha estrategia.

\section{Referencias bibliográficas}

Avey, J. B., Reichard, R. J., Luthans, F., \& Mhatre, K. H. (2011). Meta-analysis of the impact of positive psychological capital on employee attitudes, behaviors, and performance. Human Resource Development Quarterly, 22(2), 127-152. https://doi.org/10.1002/hrdq.20070

Bakker, A. B. (2013). Advances in Positive Organizational Psychology. (A. B. Bakker, Ed.) (Vol. 1). Bingley: Emerald Group Publishing. https://doi.org/10.1108/S2046410X(2013)0000001006

Bakker, A. B., \& Demerouti, E. (2017). Job demands-resources theory: Taking stock and looking forward. Journal of Occupational Health Psychology, 22(3), 273-285. https://doi.org/10.1037/ocp0000056

Bandura, A. (1997). Self-effi cacy: The exercise of control. New York: Freeman.

Bishop, S. R., Lau, M., Shapiro, S., Carlson, L., Anderson, N. D., Carmody, J., ... Devins, G. (2004). Mindfulness: A proposed operational definition. Clinical 
Psychology: Science and Practice, 11(3), 230-241. https://doi.org/10.1093/clipsy/bph077

Burke, L. A., \& Hutchins, H. M. (2007). Training transfer: An integrative literature review. Human Resource Development Review, 6(3), 263-296. https://doi.org/10.1177/1534484307303035

Cropanzano, R., \& Wright, T. A. (2001). A Review and Further Refinement of the Happy- Productive Worker Thesis. Consulting Psychology Journal, 53(3), 182199. https://doi.org/10.1037//106W087.53.3.182

Dello Russo, S., \& Stoykova, P. (2015). Psychological Capital Intervention (PCI): A Replication and Extension. Human Resource Development Quarterly, 26(3), 329347. https://doi.org/10.1002/hrdq

Demerouti, E., Eeuwijk, E. Van, Snelder, M., \& Wild, U. (2011). Assessing the effects of a "personal effectiveness" training on psychological capital, assertiveness and self-awareness using self-other agreement. Career Development International, 16(1), 60-81. https://doi.org/10.1108/13620431111107810

EU-OSHA. (2014). Calculating the cost of work-related stress and psychosocial risks. (E. A. for S. and H. at Work, Ed.). Luxembourg: Publications Office of the European Union.

Folkman, S. (2010). Stress, coping, and hope. Psycho-Oncology, 19(9), 901-8. https://doi.org/10.1002/pon.1836

Fowler, R. D., Seligman, M. E. P., \& Koocher, G. P. (1999). The APA 1998 Annual Report. American Psychologist, 54(8), 537-568. https://doi.org/10.1037/0003066X.54.8.537 
Fredrickson, B. L. (2004). The broaden-and-build theory of positive emotions. Philosophical Transactions of the Royal Society of London. Series B, Biological Sciences, 359(1449), 1367-78. https://doi.org/10.1098/rstb.2004.1512

Fugate, M., Kinicki, A. J., \& Ashforth, B. E. (2004). Employability: A psycho-social construct, its dimensions, and applications. Journal of Vocational Behavior, 65(1), 14-38. https://doi.org/10.1016/j.jvb.2003.10.005

Hobfoll, S. E. (2002). Social and psychological resources and adaptation. Review of General Psychology, 6(4), 307-324. https://doi.org/10.1037/1089-2680.6.4.307

ISSA. (2013). The return on prevention: Calculating the costs and benefits of investments in occupational safety and health in companies.

Le Blanc, P. M., \& Oerlemans, W. G. M. (2016). Amplition in the Workplace: Building a Sustainable Workforce Through Individual Positive Psychological Interventions. Psychologist Papers, 37(3), 185-191.

Lisbona, A., \& Salanova, M. (2012). Las Organizaciones saludables.pdf. In A. Osca, F. J. Palací, G. Topa, J. A. Moriano, \& A. Lisbona (Eds.), Psicologia de las Organizaciones (pp. 309-334). Madrid: EDITORIAL SANZ Y TORRES.

Luthans, F., Avey, J. B., Avolio, B. J., Norman, S. M., \& Combs, G. M. (2006). Psychological capital development: toward a micro-intervention. Journal of Organizational Behavior, 27, 387-393.

Luthans, F., \& Youssef-Morgan, C. M. (2017). Psychological Capital: An EvidenceBased Positive Approach. Annual Review of Organizational Psychology and Organizational Behavior, 4(1), 339-366. https://doi.org/10.1146/annurevorgpsych-032516-113324

Luthans, F., Youssef-Morgan, C. M., \& Avolio, B. J. (2015). Psychological Capital and Beyond. New York: Oxford University Press. 
Luthans, F., Youssef, C. M., \& Avolio, B. J. (2007). Psychological Capital: Developing the Human Competitive Edge. Oxford University Press.

Masten, a S. (2001). Ordinary magic. Resilience processes in development. The American Psychologist, 56(3), 227-238. https://doi.org/10.1037/0003066X.56.3.227

Meyers, M. C., \& Van Woerkom, M. (2017). Effects of a Strengths Intervention on General and Work-Related Well-Being: The Mediating Role of Positive Affect. Journal of Happiness Studies, 18(3), 671-689. https://doi.org/10.1007/s10902$016-9745-x$

Meyers, M. C., Van Woerkom, M., De Reuver, R. S. M., Bakk, Z., \& Oberski, D. L. (2015). Enhancing psychological capital and personal growth initiative: Working on strengths or deficiencies. Journal of Counseling Psychology, 62(1), 50-62. https://doi.org/10.1037/cou0000050

Nielsen, K., \& Miraglia, M. (2017). What works for whom in which circumstances? On the need to move beyond the "what works?" question in organizational intervention research. Human Relations, 70(1), 40-62. https://doi.org/10.1177/0018726716670226

Nielsen, K., Nielsen, M. B., Ogbonnaya, C., Känsälä, M., Saari, E., \& Isaksson, K. (2017). Workplace resources to improve both employee well-being and performance: A systematic review and meta-analysis. Work and Stress, 31(2), 101-120. https://doi.org/10.1080/02678373.2017.1304463

Peterson, C., \& Seligman, M. E. P. (2004). Character Strengths and Virtues. Oxord University Press. https://doi.org/313971759

Public Policy Exchange. (2018). The Future of Occupational Safety and Health in Europe: Strengthening Social Europe through Healthier Workplaces for Safer 
Workers.

Brussels.

Retrieved

from

https://www.publicpolicyexchange.co.uk/events/IC15-PPE2

Reichard, R. J., Dollwet, M., \& Louw-Potgieter, J. (2014). Development of Cross-

Cultural Psychological Capital and Its Relationship With Cultural Intelligence and Ethnocentrism. Journal of Leadership \& Organizational Studies, 21(2), 150-164. https://doi.org/10.1177/1548051813515517

Salanova, M., Llorens, S., Cifre, E., \& Martínez, I. M. (2012). We Need a Hero! Toward a Validation of the Healthy and Resilient Organization (HERO) Model. Group \& $\begin{array}{lll}\text { Organization } & \text { Management, } & \text { 37(6), }\end{array}$ https://doi.org/10.1177/1059601112470405

Salanova, M., Llorens, S., \& Martínez, I. M. (2016). Aportaciones desde la psicología organizacional positiva para desarrollar organizaciones saludables y resilientes. Papeles Del Psicologo, 37(3), 177-184.

Sarkar, A. (2016). We live in a VUCA World: the importance of responsible leadership. Development and Learning in Organizations: An International Journal, 30(3), 912. https://doi.org/10.1108/DLO-07-2015-0062

Seligman, M. E. P. (2011a). Flourish. Spring, 80-87. https://doi.org/10.1037/0003066X.61.8.772

Seligman, M. E. P. (2011b). Learned Optimism: How to Change Your Mind and Your Life. New York: Vintage. https://doi.org/10.1136/bmj.316.7134.870

Snyder, C. R. (2000). Handbook of hope. San Diego: Academic Press.

Tkachenko, O., Hahn, H.-J., \& Peterson, S. L. (2017). Research-Practice Gap in Applied Fields: An Integrative Literature Review. Human Resource Development Review, 16(3), 235-262. https://doi.org/10.1177/1534484317707562 
Van Wingerden, J. (2016). Job Demands-Resources Interventions. Erasmus Universiteit Rotterdam. https://doi.org/10.13140/RG.2.1.1956.7603

Williams, P., Kern, M. L., \& Waters, L. (2016). Exploring selective exposure and confirmation bias as processes underlying employee work happiness: An $\begin{array}{lllll}\text { intervention study. Frontiers in Psychology, } & 7(\mathrm{JUN}), \quad 878 .\end{array}$ https://doi.org/10.3389/fpsyg.2016.00878

Williams, P., Kern, M. L., \& Waters, L. (2017). The role and reprocessing of attitudes in fostering employee work happiness: An intervention study. Frontiers in Psychology, 8(JAN). https://doi.org/10.3389/fpsyg.2017.00028

World Health Organization. Constitution of the World Health Organization, International Health Conference $\S(1948)$. https://doi.org/12571729

World Health Organization. Mental Health Action Plan 2013-2020, WHO Library Cataloguing-in-Publication DataLibrary Cataloguing-in-Publication Data $§(2013)$. https://doi.org/10.1017/CBO9781107415324.004

Zhang, X., Li, Y.-L., Ma, S., Hu, J., \& Jiang, L. (2014). A Structured Reading MaterialsBased Intervention Program to Develop the Psychological Capital of Chinese Employees. Social Behavior and Personality: An International Journal, 42(3), 503-515. https://doi.org/10.2224/sbp.2014.42.3.503 


\section{Chapter 2. Psychological Capital Interventions: An Integrative}

\section{Review}

Proposed as a way to obtain a competitive edge, psychological capital (PsyCap) is a developable individual state-like related to well-being and performance at work. There are several literature reviews on the predictive relationship between PsyCap and desirable employee attitudes, behaviours, and performance, but Human Resources Development (HRD) scholars and practitioners have not yet benefited from a comprehensive review and update of the research on PsyCap interventions. A total of 32 studies were analysed to synthesize the published procedures, methodologies, effectiveness, and outcomes. The literature reviewed confirmed that PsyCap is a psychological state-like that can be developed through positive interventions. However, further research is necessary to improve PsyCap interventions and provide robust guidelines for HRD professionals in implementing the training as a practice for excellence. We propose a research agenda focused on comparing the effectiveness of different intervention strategies, examining desirable outcomes, exploring training transfer effects, and evaluating cultural-differences.

Keywords: psychological capital, human resource development, positive interventions, performance, well-being.

1

\footnotetext{
${ }^{1}$ Chapter 2 has been submitted for publication as: Ortega-Maldonado, A., Sánchez-Cardona, I., \& Salanova, M. Psychological Capital Interventions: An Integrative Review. Human Resource Development Review.
} 
December 2017. From the beginning of the twenty-first century, we have been living in an increasingly dynamic, global, and uncertain business world. The information and telecommunications revolution emerged about twenty years ago, and globalization has become a reality. Furthermore, a global economic and financial crisis began ten years ago, seriously affecting consumers, workers, and organizations worldwide. In this new socioeconomic era, contemporary organizations will not be the same. Organizations have to face dynamic and changing environments, and they need sustainable sources of distinct advantages and competitive edge (Kraaijenbrink, Spender, \& Groen, 2010). In this scenario, according to the resource-based theory of the firm (see Newman, Ucbasaran, Zhu, \& Hirst, 2014), accumulating traditional material resources (i.e., financial and technological capital) and recruiting experts with many years of experience (i.e., human and social capital) may be insufficient strategies for organizational success (F. Luthans, Youssef-Morgan, \& Avolio, 2015), and a sustainable and developable workforce could be of vital importance for viability and competitive advantage (Le Blanc \& Oerlemans, 2016).

Thus, at the beginning of the new century, Positive Organizational Behaviour (POB) emerged as a new evidence management and practice approach, stressing the role of Human Resource Development (HRD) as a strategic resource (valuable, rare, and imperfectly imitable) to obtain a competitive edge (F. Luthans, Youssef, \& Avolio, 2007; Newman et al., 2014). The main focus of the POB proposal is on enhancing employees' psychological resources (psychological capital), performance, and wellbeing through positive interventions, as a valuable tool to increase workforce sustainability (Le Blanc \& Oerlemans, 2016; F. Luthans, Avey, Avolio, Norman, \& Combs, 2006). POB researchers have contributed to the psychological capital (PsyCap) literature from different disciplines such as Human Resource Development, 
Occupational Health Psychology, and Organizational Behaviour and Management, with POB and PsyCap research occupying a central place in the HRD agenda.

PsyCap is defined as a positive individual psychological state-like that is measurable, developable, and highly involved in task performance and goal achievement (F. Luthans, Youssef, et al., 2007). PsyCap is a set of four psychological resources (i.e., self-efficacy, optimism, hope, and resilience) that have empirically been found to make up a higher-order core construct (F. Luthans, Avolio, Avey, \& Norman, 2007). In other words, the whole is greater than the sum of its parts. PsyCap is a dynamic topic that has experienced rapid growth in the literature (F. Luthans \& Youssef-Morgan, 2017). Extensive empirical evidence indicates that PsyCap is predictive of many important positive organizational outcomes (attitudes and behaviours) in samples of workers and pre-professionals. Examples of positive attitudes related to PsyCap include commitment (Avey, Luthans, \& Youssef, 2010; Larson \& Luthans, 2006; F. Luthans, Norman, Avolio, \& Avey, 2008; Youssef \& Luthans, 2007), engagement (Avey, Wernsing, \& Luthans, 2008; Siu, Bakker, \& Jiang, 2014), and work happiness and satisfaction (Avey, Luthans, \& Youssef, 2010; Choi \& Lee, 2014; Larson \& Luthans, 2006; F. Luthans, Avolio, et al., 2007; F. Luthans, Avolio, Norman, \& Avey, 2006; F. Luthans, Avolio, Walumbwa, \& Li, 2005; F. Luthans, Norman, et al., 2008; Youssef \& Luthans, 2007). Examples of positive behaviours include organizational citizenship behaviours (OCB) (Avey, Luthans, \& Youssef, 2010; Avey et al., 2008), self-reported performance (Choi \& Lee, 2014; Liu, 2013; F. Luthans, Avey, Clapp-Smith, \& Li, 2008; F. Luthans, Avolio, et al., 2007, 2006; F. Luthans et al., 2005; Rego, Marques, Leal, Sousa, \& Pina e Cunha, 2010; Youssef \& Luthans, 2007), manager-rated and objective performance (Avey, Luthans, \& Youssef, 2010; B. C. Luthans, Luthans, \& Jensen, 2012; Peterson, Luthans, Avolio, Walumbwa, \& Zhang, 2011), and innovative behaviour (Abbas \& Raja, 2015). 
On the other hand, PsyCap has demonstrated a predictive favourable relationship with negative organizational attitudes and behaviours (i.e., the more PsyCap, the fewer the negative outcomes). Examples of negative attitudes include absenteeism (Avey, Patera, \& West, 2006), cynicism (Avey, Luthans, \& Youssef, 2010; Avey et al., 2008), stress (Abbas \& Raja, 2015; Avey, Luthans, \& Jensen, 2009; Avey, Luthans, \& Youssef, 2010), and turnover intentions (Avey et al., 2009; Avey, Luthans, \& Youssef, 2010; Choi \& Lee, 2014). Examples of negative behaviours include deviance (Avey et al., 2008) and job search (Avey et al., 2009). Additionally, the PsyCap literature shows that PsyCap predicts happiness, life satisfaction, and both hedonic and eudemonic psychological wellbeing (Avey, Luthans, Smith, \& Palmer, 2010; Baron, Franklin, \& Hmieleski, 2013; Choi \& Lee, 2014; Culbertson, Fullagar, \& Mills, 2010) (see Hervás \& Vázquez, 2013 for more information about hedonic and eudemonic well-being).

The state-like property of PsyCap means that its development is possible through interventions (F. Luthans, Avey, \& Patera, 2008). Since Luthans and colleagues proposed the Psychological Capital Intervention (PCI) model (F. Luthans, Youssef, et al., 2007), a large body of research on PsyCap development has been published. There is empirical evidence about face-to-face micro-interventions (F. Luthans, Avey, Avolio, \& Peterson, 2010) and web-based interventions (F. Luthans, Avey, \& Patera, 2008) in samples of students and employees (Dello Russo \& Stoykova, 2015), people at risk of social exclusion (Rew, Powell, Brown, Becker, \& Slesnick, 2017), and expatriate workers (Reichard, Dollwet, \& Louw-Potgieter, 2014). The majority of the PsyCap intervention literature replicates the $\mathrm{PCl}$. However, some of the research is based on PCI but introduces some variation (Rew et al., 2017), creates a new PsyCap intervention approach (Zhang, Li, Ma, Hu, \& Jiang, 2014), or merges PsyCap and strengths interventions (Meyers, Van Woerkom, De Reuver, Bakk, \& Oberski, 2015). There is also evidence of a PsyCap increase at the end of the intervention (F. Luthans, 
Avey, \& Patera, 2008), and even after a follow-up period (Reichard et al., 2014). Moreover, PsyCap development increases positive outcomes in performance levels ( $F$. Luthans et al., 2010), assertiveness (Demerouti, Eeuwijk, Snelder, \& Wild, 2011), positive emotions (Reichard et al., 2014), and job satisfaction (Harty, Gustafsson, Björkdahl, \& Möller, 2016).

\section{Purpose of the study}

There are theoretical compilations of the predictive relationship between PsyCap and desirable employee attitudes, behaviours, and performance (F. Luthans et al., 2015; F. Luthans, Youssef, et al., 2007), and there are also literature reviews (Dawkins, Martin, Scott, \& Sanderson, 2013; F. Luthans, 2012; F. Luthans \& YoussefMorgan, 2017; Newman et al., 2014) and meta-analysis (Avey, Reichard, Luthans, \& Mhatre, 2011) on this topic. This literature supports the higher-order factor structure of the core construct, the prediction of positive outcomes (i.e., self-reported, managerrated and objective performance, problem solving, innovative behaviour, OCB, commitment, job satisfaction, and psychological well-being), and the prediction of lower levels of negative outcomes (i.e., absenteeism, counterproductive work behaviours, cynicism, deviance, job search behaviours, stress, and turnover intentions).

However, to the best of our knowledge, HRD scholars and practitioners have not yet benefited from a comprehensive review and update of the literature on PsyCap interventions. Based on $\mathrm{POB}$ evidence-based practice and management proposals ( $\mathrm{F}$. Luthans \& Youssef-Morgan, 2017), we believe that an integrative review of individual PsyCap development is now important and necessary in order to develop more rigorous $\mathrm{HRD}$ and performance programs. This review may be useful, at least in this stage of the research, for increasing practitioners' confidence in PsyCap interventions. Thus, addressing the call by Dello Russo and Stoykova (2015) to improve the generalizability and external validity of PsyCap interventions, this study aims to review the PsyCap intervention literature and synthesize its effectiveness and outcomes. 
Specifically, we analysed literature on PsyCap intervention procedures, methodologies, effectiveness, and outcomes. These factors can help HRD professionals to choose the best procedure to implement their interventions in specific organizational settings. Our conclusions may help shed light on PsyCap interventions and contribute to both POB scholarship and practice excellence (F. Luthans, 2012). The search method utilized and the results of the analysis of the literature are described in the following section.

\section{Method}

\section{Search method}

The search for literature was divided into three different steps: 1) searching scientific databases, 2) searching additional sources, 3) searching references found in selected studies. PsyCap interventions are an emerging and applied topic related to scholarly and professional activity. To provide a comprehensive and integrative perspective on this topic, we followed the integrative review methodology proposals (Torraco, 2016), and we decided to analyse different types of publications. Thus, we systematically searched both research and professional literature, including journal articles, doctoral dissertations, books, chapters, and conference papers.

First step. Three databases on business, management, and psychology were searched (PsycNet, ABI/INFORM complete, and ProQuest Central). We used two keywords as descriptors ("psychological capital" and "PsyCap"), combined with one operator "and" ("intervention"). We searched two different fields: "title" and "abstract". Literature on PsyCap interventions was selected for review only if, after reading the abstract, it met all of the following retention criteria (results appear in table 1):

- They were focused on PsyCap interventions (application and evaluation). Theoretical and basic research literature was excluded for the purposes of this review. 
- They were written in English or Spanish. Texts in Chinese, Farsi, Lithuanian, and Turkish were excluded from the review.

- They were accessible through the University electronic library by at least one of the three authors. Works with no accessibility were requested from the corresponding authors by email, and they were excluded if no positive answer was received.

Second step. We decided to complete the search by using additional sources of information. We searched publications by the main PsyCap authors, visiting their Google Scholar and Researchgate profiles. Finally, we searched a topic-related, specific, applied journal: "The Positive Work and Organizations: Research and Practice (PWORP)", which belongs to a scientific and professional association: the Work and Organizations Division of the International Positive Psychology Association (http://www.ippanetwork.org) (results appear in table 1).

Table 1.Search results by publications type

\begin{tabular}{|c|c|c|c|c|c|c|}
\hline $\begin{array}{l}\text { Type of } \\
\text { publication }\end{array}$ & & Step 1 & & Step 2 & Step 3 & $\begin{array}{c}\text { Final } \\
\text { Retained }\end{array}$ \\
\hline & Found & Discarded & Retained & Added & Added & \\
\hline $\begin{array}{c}\text { Research } \\
\text { journal article }\end{array}$ & 48 & 31 & 17 & 2 & 0 & 19 \\
\hline Dissertation & 14 & 7 & 7 & 2 & 1 & 10 \\
\hline Book & 2 & 0 & 2 & 0 & 0 & 2 \\
\hline Chapter & 1 & 1 & 0 & 0 & 0 & 0 \\
\hline $\begin{array}{l}\text { Professional } \\
\text { journal article }\end{array}$ & 3 & 3 & 0 & 0 & 0 & 0 \\
\hline $\begin{array}{l}\text { Conference } \\
\text { papers }\end{array}$ & 2 & 2 & 0 & 1 & 0 & 1 \\
\hline Total & 70 & 44 & 26 & 5 & 1 & 32 \\
\hline
\end{tabular}


Third step. We added literature found after reading the selected studies (results appear in table 1).

\section{Analysis of the literature}

Finally, we analysed 32 works (table 2). We used Mendeley to store, organize, and read the articles. A complete reading of each selected literature source was conducted. We classified the information according to the objectives of the study, identifying and analysing the research characteristics (i.e. design, participants, sample, and measures), the intervention objective and procedure (i.e. timing, schedule, organization, and psychological structure), and the main results displayed (i.e. PsyCap increase, outcomes, comparisons across conditions, and effect significance and size). In order to homogenize the data reported by every study reviewed, we calculated the percentage of increase or decrease in each variable from each study. We subtracted the final score from the initial one, and then we calculated the corresponding percentage with respect to the measurement scale. If necessary, we searched original scales to find range ratings and understand variable calculating procedures. Finally, we classified the information in several documents and files in order to analyse and draw conclusions about the state-of-the-art.

In the following sections, we present the main themes that emerged from the reviewed literature. To facilitate understanding of the paper, we divide the information into several subsections focused on the research characteristics of the studies, the intervention procedures conducted, and the main results obtained. Finally, we conclude with proposals and calls for future research directions on PsyCap interventions. 
Table 2. Literature analysed

\begin{tabular}{|c|c|}
\hline Reference & Type of publication \\
\hline (Larson, 2004) & Thesis dissertation \\
\hline (F. Luthans, Avey, Avolio, Norman, \& Combs, 2006) & Journal JCR \\
\hline (F. Luthans, Youssef, \& Avolio, 2007) & Book \\
\hline (F. Luthans, Avey, \& Patera, 2008) & Journal JCR \\
\hline (Griffith, 2010) & Thesis dissertation \\
\hline (Hodges, 2010) & Thesis dissertation \\
\hline (F. Luthans, Avey, Avolio, \& Peterson, 2010) & Journal JCR \\
\hline (Demerouti, Eeuwijk, Snelder, \& Wild, 2011) & Journal JCR \\
\hline (Babinchak, 2012) & Thesis dissertation \\
\hline (Hargrove, 2012) & Thesis dissertation \\
\hline (Sherlock-Storey, Moss, \& Timson, 2013) & Journal no JCR \\
\hline (Bauman, 2014) & Thesis dissertation \\
\hline (Dello Russo, 2014) & Conference paper \\
\hline (B. C. Luthans, Luthans, \& Avey, 2014) & Journal JCR \\
\hline (Reichard, Dollwet, \& Louw-Potgieter, 2014) & Journal JCR \\
\hline (Zhang, Li, Ma, Hu, \& Jiang, 2014) & Journal JCR \\
\hline (Dello Russo \& Stoykova, 2015) & Journal JCR \\
\hline (Diedrich, 2015) & Thesis dissertation \\
\hline (Ertosun, Erdil, Deniz, \& Alpkan, 2015) & Journal no JCR \\
\hline
\end{tabular}




\section{Emergent themes from the literature}

Several themes associated with the purposes of the present review emerged from the literature. These themes were aligned with the "research and practice" characteristic of POB and PsyCap. We then decided to classify the information in three main fields: 1) research characteristics, related to experimental and design methodology; 2) PsyCap intervention procedures, related to psychological strategies for developing PsyCap; and 3) intervention efficacy and outcomes, related to the improvement in PsyCap and its effects after conducting PsyCap interventions. We address the call by Tkachenko, Hahn and Peterson (2017), whose literature review on research-practice gap in applied fields highlights the importance of reinforcing the links 
between academic research and professional practice. Thus, we report the results of our review, considering scholars' and practitioners' interests and practice in PsyCap interventions.

\section{Research characteristics}

The analysis of the research characteristics sheds light on generalization, an important and traditional research concern that also affects the PsyCap intervention literature. Generalization refers to the replicability and external validity of the research, and it may be decisive in HRD because it influences practitioners' and managers' decisions to invest in developmental activities in organizations (Dello Russo \& Stoykova, 2015). Thus, for HRD practitioners, higher levels of generalization of PsyCap intervention research may be a determinant of higher levels of confidence in conducting PsyCap interventions in organizations.

Study designs. To obtain conclusions about the effectiveness of the PsyCap interventions, researchers selected different study designs. As table 3 shows, most of the studies reviewed (94\%) used a within comparison methodology, which means measuring the study variables before and after the intervention and comparing the PsyCap scores to determine the increase, decrease, or stability of PsyCap after the intervention. In addition, some of the studies (24\%) reported follow-up measures designed to assess the durability of the PsyCap intervention effects. A variety of strategies were used to measure the follow-up of the interventions. For example, Bauman (2014) measured the effects two weeks after the intervention was over, and other researchers conducted the follow-up measure one month after the last training session (Dello Russo \& Stoykova, 2015; Meyers \& Van Woerkom, 2017; Meyers et al., 2015; Rew et al., 2017), between one and two months later (Reichard et al., 2014), three months after the intervention (Zhang et al., 2014), or even six months later (Harty et al., 2016). Moreover, one study (Meyers et al., 2015) reported two different follow-up measures, at the first and third month. 
Furthermore, there were more sophisticated strategies used to demonstrate whether the interventions were effective in developing PsyCap. Some studies (62\%) conducted between-group comparisons, which agrees with Fred Luthans and colleagues' proposal (2007) to design interventions beyond the measurement of PsyCap before and after the intervention. Some of these studies (38\%) compared the intervention group to a Waiting List group (WL) that did not receive the developmental intervention (Babinchak, 2012; Bauman, 2014; Dello Russo \& Stoykova, 2015; Ertosun, Erdil, Deniz, \& Alpkan, 2015; Hargrove, 2012; Harty et al., 2016; Hodges, 2010; Meyers \& Van Woerkom, 2017; Van Wingerden, Bakker, \& Derks, 2016; Van Wingerden, Derks, \& Bakker, 2017; Williams, Kern, \& Waters, 2016; Zhang et al., 2014). Other studies (24\%) compared the intervention group to a control group that received alternative interventions, such as decision-making training, information sessions, or team-building and leadership development (Griffith, 2010; Larson, 2004; B. C. Luthans, Luthans, \& Avey, 2014; F. Luthans, Avey, et al., 2006; F. Luthans et al., 2010; F. Luthans, Avey, \& Patera, 2008; O' Reilly, 2016; Rew et al., 2017). For practical reasons related to obtaining a well-fitting design, the assignment of the participants to each condition was randomized in only $48 \%$ of the literature reviewed. Thus, a quasi-experimental design seems to be a well-accepted strategy in PsyCap intervention research (see table 3).

Participants. Another important research characteristic that emerged from the literature is related to the intervention's participants (table 3). We found studies conducted with workforce samples (43\% employees and $21 \%$ managers, supervisors or team leaders), pre-professional samples (30\%), and samples of unemployed people (6\%). Employees involved in the PsyCap intervention studies worked in different business sectors, such as education, health, technology, industry, or publishing. They belonged to public, private, or non-governmental organizations (NGO), and mainly performed administrative, technical, or managerial tasks. Finally, most of the 
interventions were conducted in the USA (52\%) and the Netherlands (15\%), whereas $6 \%$ took place in Turkey, $6 \%$ in Australia, and the rest in other European (UK, Bulgaria, Sweden, and Ireland), Asian (China), South American (Venezuela), and African (South Africa) countries.

PsyCap approach. The primary purpose of the reviewed PsyCap interventions was the development of PsyCap in the participants. Most of the studies $(73 \%)$ addressed the PsyCap higher-order core approach, but some of the literature conducted interventions to develop its components separately (i.e. self-efficacy, hope, optimism, and resilience) (Bell, 2016; Harty et al., 2016; Meyers et al., 2015). Finally, other studies took a mixed approach, measuring PsyCap development as a higherorder construct, but also addressing the lower-order components (Babinchak, 2012; Dello Russo, 2014; Dello Russo \& Stoykova, 2015; Demerouti et al., 2011; Larson, 2004; O' Reilly, 2016; Rew et al., 2017). Mainly, PsyCap development followed the original conception of individual state-like capacities related to work performance ( $F$. Luthans, Youssef, et al., 2007). However, other studies adapted this conception to academic performance (B. C. Luthans et al., 2014), safe health attitudes and behaviours (Rew et al., 2017), PsyCap as an overall life capacity for self-development (B. C. Luthans et al., 2014), and even cross-cultural adaptations of PsyCap (Reichard et al., 2014).

PsyCap development outcomes. Furthermore, some of the literature reviewed aimed not only to enhance participants' PsyCap levels, but also to obtain positive workrelated and personal outcomes. PsyCap development interventions were designed to increase performance in $15 \%$ of the studies, either self-reported in-role performance (Van Wingerden et al., 2016, 2017; Zhang et al., 2014), or when combining selfreported and manager-rated performance (Hodges, 2010; F. Luthans et al., 2010). In a weekly PsyCap intervention with female homeless youth, goal attainment was used as a type of performance measurement (Rew et al., 2017). In addition to job performance 
enhancement, several studies aimed to increase positive academic and job attitudes, such as assertiveness, cultural intelligence, readiness for change, or social connectedness (Demerouti et al., 2011; Reichard et al., 2014; Rew et al., 2017; Sherlock-Storey, Moss, \& Timson, 2013). Moreover, other studies were designed to increase job crafting behaviours (Van Wingerden et al., 2016). Decreases in levels of negative attitudes, such as ethnocentrism at work, were also aims in PsyCap intervention research (Reichard et al., 2014).

PsyCap interventions were also designed to enhance employees' health and wellbeing, both work-related and whole life-related. On the one hand, there were studies designed to boost well-being at work. At least $12 \%$ of the research literature reviewed aimed to achieve higher levels of engagement through PsyCap interventions (Hodges, 2010; Meyers \& Van Woerkom, 2017; Van Wingerden et al., 2016). Increases in levels of job satisfaction, work happiness, psychosocial work environment, and positive affect, as well as decreases in burnout, were also objectives for researchers (Harty et al., 2016; Meyers \& Van Woerkom, 2017; Reichard et al., 2014; Williams et al., 2016). On the other hand, other studies aimed to obtain higher levels of general psychological health and well-being, measuring outcomes such as personal growth initiative, life satisfaction, and a future time perspective (Bauman, 2014; Meyers \& Van Woerkom, 2017; Meyers et al., 2015; Rew et al., 2017).

Additionally, the literature review showed some research on psychological variables related to the effectiveness of PsyCap interventions. Thus, some of the studies measured antecedents of the intervention, such as pre-training and participants' motivation to transfer training, their perceptions of the organizational virtues (Griffith, 2010; Williams et al., 2016), and the cognitive mechanisms and dynamics during the PsyCap intervention, such as confirmation bias and selective exposures (Williams et al., 2016). Additionally, we found a qualitative study addressing the participants' evaluation of the intervention experience (Kalman \& Summak, 2017). 
PsyCap measurement. According to the POB criteria (F. Luthans et al., 2015; F. Luthans, Youssef, et al., 2007), one of the most important characteristics of PsyCap is that it is measurable. PsyCap measurement is the main strategy used to test this developmental characteristic after an intervention. A 24-item PsyCap questionnaire called the PCQ was developed by Fred Luthans and colleagues (F. Luthans, Avolio, et al., 2007) and validated across diverse samples from a wide range of organizations throughout the world (for a PCQ literature review, see Dawkins et al., 2013). Coinciding with the results obtained in all the previous PsyCap literature reviews and metaanalysis (Avey et al., 2011; Dawkins et al., 2013; F. Luthans \& Youssef-Morgan, 2017; Newman et al., 2014), we found that the most widely used measure of PsyCap in the developmental literature was the PCQ-24 (73\%). Other strategies used to evaluate PsyCap consisted of combining PsyCap component measures (Demerouti et al., 2011; Harty et al., 2016; Larson, 2004; Meyers \& Van Woerkom, 2017; Meyers et al., 2015; Van Wingerden et al., 2016, 2017), using a questionnaire designed to measure PsyCap in a specific approach (i.e. cross-cultural PsyCap) (Reichard et al., 2014), or measuring PsyCap through a qualitative methodology such as a semi-structured interview (Kalman \& Summak, 2017).

Finally, the reviewed literature generally measured PsyCap using a self-report questionnaire, but three of the studies proposed other-rated strategies to capture PsyCap, such as asking partners, assistants, or supervisors (Demerouti et al., 2011; Hodges, 2010; F. Luthans et al., 2010). 
Table 3. Studies design and participants

\begin{tabular}{|c|c|c|c|c|c|}
\hline Study & Design & Sample & Random & Participants & Country \\
\hline (Larson, 2004) & $\begin{array}{l}\text { Pre-Post } \\
\text { Control }\end{array}$ & $\begin{array}{l}38 \\
36\end{array}$ & Yes & Employees of a manufacturing company & USA \\
\hline \multirow{3}{*}{$\begin{array}{c}\text { (F. Luthans, Avey, Avolio, Norman, \& } \\
\text { Combs, 2006) } \\
\text { (F. Luthans, Youssef, \& Avolio, 2007) } \\
\text { (F. Luthans, Youssef-Morgan, \& Avolio, } \\
\text { 2015) }\end{array}$} & $\begin{array}{l}\text { Pre-Post } \\
\text { Control }\end{array}$ & $\begin{array}{l}\mathrm{NI} \\
\mathrm{NI}\end{array}$ & Yes & Management students & USA \\
\hline & Pre-Post & $\begin{array}{l}\mathrm{NI} \\
\mathrm{NI}\end{array}$ & No & $\begin{array}{l}\text { Managers from different companies and } \\
\text { sectors }\end{array}$ & USA \\
\hline & Pre-Post & 74 & No & $\begin{array}{l}\text { Engineering managers of a high tech } \\
\text { company }\end{array}$ & USA \\
\hline $\begin{array}{l}\text { (F. Luthans, Avey, \& Patera, 2008) } \\
\quad \text { (F. Luthans et al., 2015) }\end{array}$ & $\begin{array}{l}\text { Pre-Post } \\
\text { Control }\end{array}$ & $\begin{array}{l}187 \\
177\end{array}$ & Yes & $\begin{array}{l}\text { Workers from several industries (41\% } \\
\text { supervisors) }\end{array}$ & USA \\
\hline (Griffith, 2010) & $\begin{array}{l}\text { Pre-Post } \\
\text { Control }\end{array}$ & $\begin{array}{l}92 \\
94\end{array}$ & Yes & $\begin{array}{l}\text { Retail employees from three stores (same } \\
\text { company) }\end{array}$ & USA \\
\hline (Hodges, 2010) & $\begin{array}{l}\text { Pre-Post } \\
\text { WL }\end{array}$ & $\begin{array}{l}58 \\
52\end{array}$ & Yes & Mangers (financial services) & USA \\
\hline \multirow{2}{*}{$\begin{array}{l}\text { (F. Luthans, Avey, Avolio, \& Peterson, 2010) } \\
\text { (F. Luthans et al., 2015) }\end{array}$} & $\begin{array}{l}\text { Pre-Post } \\
\text { Control }\end{array}$ & $\begin{array}{c}153 \\
89\end{array}$ & Yes & $\begin{array}{l}\text { Advanced management students from the } \\
\text { same university }\end{array}$ & USA \\
\hline & Pre-Post & 80 & No & $\begin{array}{l}\text { Practicing managers from different } \\
\text { companies }\end{array}$ & USA \\
\hline (Demerouti, Eeuwijk, Snelder, \& Wild, 2011) & Pre-Post & 36 & No & Users of a training bureau & The Netherlands \\
\hline (Babinchak, 2012) & $\begin{array}{l}\text { Pre-Post } \\
\text { WL }\end{array}$ & $\begin{array}{l}174 \\
79\end{array}$ & Yes & $\begin{array}{l}\text { First-term students from various career } \\
\text { colleges }\end{array}$ & USA \\
\hline (Hargrove, 2012) & $\begin{array}{l}\text { Pre-Post } \\
\text { WL }\end{array}$ & $\begin{array}{l}42 \\
49\end{array}$ & Yes & Employees of a publishing company & USA \\
\hline (Sherlock-Storey, Moss, \& Timson, 2013) & Pre-Post & 12 & No & $\begin{array}{l}\text { Middle managers from a public sector } \\
\text { organization }\end{array}$ & UK \\
\hline
\end{tabular}


(Bauman, 2014)

(Dello Russo, 2014)

(Dello Russo \& Stoykova, 2015)

(B. C. Luthans, Luthans, \& Avey, 2014)

Reichard, Dollwet, \& Louw-Potgieter, 2014

(Zhang, Li, Ma, Hu, \& Jiang, 2014)

(Diedrich, 2015)

(Ertosun, Erdil, Deniz, \& Alpkan, 2015)

(Meyers, Van Woerkom, De Reuver, Bakk, \& Oberski, 2015)

$$
\text { (Bell, 2016) }
$$

(Gutierrez, 2016)

(Harty, Gustafsson, Björkdahl, \& Möller 2016)

(O’ Reilly, 2016)

(Van Wingerden, Bakker, \& Derks, 2016) (Van Wingerden, 2016)
Pre-Post-follow up (2 weeks)

WL

Pre-Post-follow up (1 month)

WL

Pre-Post

Control

Pre-Post

Pre-Post-follow up (1-2 months)

Pre-Post-follow up (3 months)

WL

Pre-Post

Pre-Post / Post

WL / WL Post

Pre-Post-two follow up (1 and 3 months)

Pre-Post

Pre-Post

Pre-Post-follow up (6 months)

Pre-Post

Control

Pre-Post

WL
Undergraduate students from the same university

Students and employees from a variety of

$$
\text { jobs }
$$

Business students from two universities

USA

Leaders from different organizations

Administrative \& staff members at a$$
\text { university }
$$

South Africa

China

USA

Turkey

Graduate students in a social sciences master's program of the same University

The Netherlands

USA

University students of the same course and institution

Venezuela

Employees of workplace units of a nongovernmental organization

College students from the same programme at a business school

Ireland

Healthcare professionals from two centres (same organization) 


\begin{tabular}{|c|c|c|c|c|c|}
\hline \multirow{2}{*}{ (Williams, Kern, \& Waters, 2016) } & $\begin{array}{l}\text { Pre-Post } \\
\text { WL }\end{array}$ & $\begin{array}{l}51 \\
18\end{array}$ & No & $\begin{array}{l}\text { School staff from the same institution } \\
\text { (teaching and non-teaching roles) }\end{array}$ & Australia \\
\hline & Pre-Post & 89 & No & $\begin{array}{l}\text { School staff from the same institution } \\
\text { (teaching and non-teaching roles) }\end{array}$ & Australia \\
\hline (Kalman \& Summak, 2017) & Post & 12 & No & $\begin{array}{c}\text { Middle school teachers from eight different } \\
\text { organizations }\end{array}$ & Turkey \\
\hline (Meyers \& Van Woerkom, 2017) & $\begin{array}{l}\text { Pre-Post-follow up (1 month) } \\
\text { WL }\end{array}$ & $\begin{array}{l}67 \\
63\end{array}$ & No & $\begin{array}{c}\text { Working adults in diverse sectors and } \\
\text { organizations }\end{array}$ & The Netherlands \\
\hline $\begin{array}{l}\text { w, Powell, Brown, Becker, \& Slesnick, } \\
\text { 2017) }\end{array}$ & $\begin{array}{c}\text { Pre-Post-follow up (1 month) (repeated measures) } \\
\text { Control }\end{array}$ & $\begin{array}{l}27 \\
20\end{array}$ & Yes & Female homeless youth from two facilities & USA \\
\hline $\begin{array}{l}\text { an Wingerden, Derks, \& Bakker, 2017) } \\
\text { (Van Wingerden, 2016) }\end{array}$ & $\begin{array}{l}\text { Pre-Post } \\
\text { WL }\end{array}$ & $\begin{array}{c}84(26+32+26)^{b} \\
18\end{array}$ & No & $\begin{array}{l}\text { Primary school teachers form four different } \\
\text { primary schools for special education }\end{array}$ & The Netherlands \\
\hline
\end{tabular}

Note. $\mathrm{NR}=$ information not reported; Control = alternative intervention; $\mathrm{WL}=$ waiting list or absent treatment; Random = randomly assigned.

${ }^{\text {a }}$ Two different interventions conducted.

${ }^{\mathrm{b}}$ Three different interventions conducted. 


\section{PsyCap intervention procedures}

Several PsyCap intervention procedures emerged from the analysis of the literature. The reviewed studies showed differences in the psychological strategies designed to develop PsyCap, the format of the sessions conducted, and the transfer training approaches considered.

Psychological strategies designed to develop PsyCap. Our integrative literature review found that the most popular procedure to develop PsyCap to date is the Psychological Capital Intervention model $(\mathrm{PCl})$. At least $38 \%$ of the studies reviewed conducted $\mathrm{PCl}$, either the original version proposed by Fred Luthans and colleagues (2007) or an adapted or similar intervention based on the PCI proposal (see table 4). $\mathrm{PCl}$ is a micro-intervention that generally consists of a 1-4 hour group workshop designed to develop PsyCap through different strategies to increase participants' levels of each of the four PsyCap components. Based on previous research on self-efficacy, hope, optimism, and resilience development, $\mathrm{PCI}$ proposes to participants a wide range of activities aimed to develop each resource through several cognitive and affective strategies (F. Luthans, 2012). Moreover, due to the higher-order core construct property of PsyCap, the PCl approach is a synergetic model based on increasing PsyCap through the reinforcing effects of the development of its components in the activities performed (for more information about $\mathrm{PCl}$, see $\mathrm{F}$. Luthans, Avey, et al., 2006; F. Luthans et al., 2015; F. Luthans, Youssef, et al., 2007). Next, we synthesize the psychological strategies used to develop each of the PsyCap components we detected when reviewing the literature.

Hope development strategies are mainly grounded in Snyder's theory and research on Hope (2000), which proposes two primary cognitive processes for hopebuilding: will-power (agency) and way-power (pathway). Hope is conceptualized as a positive goal-directed motivational state, and so several activities to improve the individual's goal design capacity were suggested in the literature. Thus, activities such 
as SMART goal-setting (designing Specific, Measurable, Achievable, Relevant and Time-bound goals), stepping (dividing goals into several sub-goals) and learning to fit goals to personal values and challenges, are conducted to enhance agency ( $F$. Luthans et al., 2015). On the other hand, way-power is addressed as a pathway generation capacity to overcome obstacles. Activities are focused on learning to adopt an approach orientation rather than an avoidance orientation, obstacle planning and designing alternative pathways, and positive self-talk training. Participants usually work on their own the first time and then share their ideas and reflections through group activities. Practices such as real task-related role-play were also conducted in the hope development training.

Optimism development strategies are mainly based on the positive expectancy definition of this positive resource (Seligman, 2011). Optimism training is focused on learning to accept the past, appreciate the present, and be confident through opportunity-seeking for the future. Suggested activities are again self-talk training in positive and realistic expectations, and reported activities such as the "best positive self" exercise (Sheldon \& Lyubomirsky, 2006), and the ABCDE model (Seligman, 2011). This is a cognitive strategy to address life's bad circumstances, being aware of real Adversity, self-related Beliefs, and real Consequences, to Dispute personal negative beliefs, and Energize proactive behaviour to overcome the setback. Because PsyCap is a higher-order construct, optimism is also developed through hope, selfefficacy, and resilience training.

Self-efficacy development strategies are grounded in social cognitive theory (Bandura, 1997), which proposes self-efficacy development via five psychological processes: task mastery, vicarious learning and role modelling, social persuasion, positive feedback, and physiological and psychological arousal. Activities suggested in the PsyCap development literature are visualization (mastery-experiences) and 
communication skills exercises (positive feedback). Moreover, self-efficacy is trained through group interaction (social persuasion) and facilitator interaction (modelling).

Resilience development strategies are designed to obtain an ideal resilience process, characterized by having a realistic and objective perception of negative events and performing ideal reactions when setbacks arise. The interventions reviewed focused on three well-recognized elements of resilience: 1) increasing asset factors, 2) decreasing risk factors, and 3) enhancing an adaptive perception of influence processes when adverse events occurs (Masten, 2001). Thus, activities suggested to increase asset factors were recognizing and increasing personal, group, and organizational resources, such as personal reflexion and communication skill exercises. Activities suggested to decrease risk factors were focused, on the one hand, on diminishing stressors through visualizing, anticipating, and planning obstacles to proactively avoid risk of adversities. On the other hand, activities were focused on mobilizing the power of the individual's adaptation system through training in adaptive coping and problem-solving strategies, enhancing stress management skills, and practicing goal-setting exercises. Activities suggested for enhancing the adaptive perception of influence processes when adverse events occur involve cognitive reframing of adverse events (ABCDE model). In summary, the resilience development strategies were mostly designed to increase participants' level of control and pathway generation when obstacles arise and hinder the desired goal.

As table 4 shows, other interventions for developing PsyCap consist of general positive psychology interventions (Williams et al., 2016) or specific positive psychology interventions, such as strengths development (Bell, 2016; Meyers \& Van Woerkom, 2017; Meyers et al., 2015), personal resources intervention (Van Wingerden et al., 2017), and positive focus training and constructive problem-solving exercises (Harty et al., 2016). Moreover, the PsyCap intervention literature also utilized Organizational or Clinical Psychology procedures to enhance participants' PsyCap levels. For example, 
Demerouti and colleagues (2011) conducted a programme based on the psychotherapeutic approach called Rational-Emotive Therapy (RET). Work and Organizational psychology interventions such as career development (Babinchak, 2012), job crafting intervention (Van Wingerden et al., 2017), job demands and resources intervention (Van Wingerden, 2016), coaching (Sherlock-Storey et al., 2013), and personal branding intervention (Bell, 2016) appeared in the literature as PsyCap development strategies. Furthermore, we found research on PsyCap development based on traditional Psychology, either with traditional contents such as deficiency intervention (Meyers et al., 2015) or traditional procedures such as a reading intervention (Zhang et al., 2014).

Finally, researchers also designed PsyCap development strategies that combine $\mathrm{PCl}$ and specific positive contents. We found combinations of $\mathrm{PCl}$ and happiness (Hodges, 2010), stress management (Hargrove, 2012), health risk behaviour avoidance (Rew et al., 2017), and even cross-cultural interactions (Reichard et al., 2014). 
Table 4. PsyCap intervention procedures ordered by duration

\begin{tabular}{|c|c|c|c|c|}
\hline Timing & $\begin{array}{l}\text { Type of } \\
\text { session }\end{array}$ & Intervention model & Follow up activities & Studies \\
\hline $1 \times 30 \mathrm{~min}$ & Individual & Reading intervention & - & (Zhang, Li, Ma, Hu, \& Jiang, 2014) \\
\hline $1 \times 37 \mathrm{~min}$ & $\begin{array}{l}\text { Computer- } \\
\text { based } \\
\text { (individual) }\end{array}$ & $\mathrm{PCl}$ & - & (Griffith, 2010) \\
\hline $1 \times 1 \mathrm{~h}$ & $\begin{array}{l}\text { Face-to-face } \\
\text { (group) }\end{array}$ & $\mathrm{PCl}$ & - & $\begin{array}{l}\text { (F. Luthans, Avey, Avolio, Norman, } \\
\text { \& Combs, 2006; O' Reilly, 2016) }\end{array}$ \\
\hline $1 \times 2 h$ & $\begin{array}{l}\text { Face-to-face } \\
\text { (group) }\end{array}$ & $\mathrm{PCl}$ & - & $\begin{array}{l}\text { (Gutierrez, 2016; B. C. Luthans, } \\
\text { Luthans, \& Avey, 2014; F. Luthans } \\
\text { et al., 2006; F. Luthans, Avey, } \\
\text { Avolio, \& Peterson, 2010) }\end{array}$ \\
\hline $1 \times 2 h$ & $\begin{array}{l}\text { Face-to-face } \\
\text { (group) }\end{array}$ & $\begin{array}{l}\text { Cross-cultural } \\
\text { PsyCap training }\end{array}$ & - & $\begin{array}{c}\text { (Reichard, Dollwet, \& Louw- } \\
\text { Potgieter, 2014) }\end{array}$ \\
\hline $1 \times 2 h$ & $\begin{array}{l}\text { Face-to-face } \\
\text { (group) }\end{array}$ & $\begin{array}{l}\text { PsyCap developing } \\
\text { training program } \\
\text { (similar to } \mathrm{PCl})\end{array}$ & - & $\begin{array}{l}\text { (Ertosun, Erdil, Deniz, \& Alpkan, } \\
\text { 2015) }\end{array}$ \\
\hline $1 \times 2.5 h$ & $\begin{array}{l}\text { Face-to-face } \\
\text { (group) }\end{array}$ & $\mathrm{PCl}$ & - & $\begin{array}{l}\text { (F. Luthans et al., 2006; F. } \\
\text { Luthans, Youssef, \& Avolio, 2007) }\end{array}$ \\
\hline $1 \times 1-3 h$ & $\begin{array}{l}\text { Face-to-face } \\
\text { (group) }\end{array}$ & $\mathrm{PCl}$ & - & (F. Luthans et al., 2007) \\
\hline $1 \times 1-3 h$ & $\begin{array}{l}\text { Face-to-face } \\
\text { (group) }\end{array}$ & $\begin{array}{l}\text { HERO workshop } \\
\text { (similar to PCl) }\end{array}$ & - & $\begin{array}{c}\text { (Dello Russo, 2014; Dello Russo \& } \\
\text { Stoykova, 2015) }\end{array}$ \\
\hline $1 \times 3 h$ & $\begin{array}{l}\text { Face-to-face } \\
\text { (group) }\end{array}$ & $\mathrm{PCl}$ & - & (Diedrich, 2015) \\
\hline $1 \times 3 h$ & $\begin{array}{l}\text { Face-to-face } \\
\text { (group) }\end{array}$ & $\begin{array}{l}\text { SOAR personal } \\
\text { branding intervention }\end{array}$ & - & (Bell, 2016) \\
\hline $1 \times 3.5 \mathrm{~h}$ & $\begin{array}{l}\text { Face-to-face } \\
\text { (group) }\end{array}$ & $\mathrm{PCl}+$ happiness & $\begin{array}{l}\text { Weekly } \\
\text { (4 weeks) }\end{array}$ & (Hodges, 2010) \\
\hline $1 / 2$ day & $\begin{array}{l}\text { Face-to-face } \\
\text { (group) }\end{array}$ & $\begin{array}{l}\text { Strengths } \\
\text { intervention }\end{array}$ & Homework tasks & (Meyers \& Van Woerkom, 2017) \\
\hline 1 day & $\begin{array}{l}\text { Face-to-face } \\
\text { (group) }\end{array}$ & $\begin{array}{l}\text { Strengths } \\
\text { intervention }\end{array}$ & $\begin{array}{c}2 \text { short homework tasks } \\
(2 \text { weeks and } 2 \text { months } \\
\text { after) }\end{array}$ & $\begin{array}{c}\text { (Meyers, Van Woerkom, De } \\
\text { Reuver, Bakk, \& Oberski, 2015) }\end{array}$ \\
\hline 1 day & $\begin{array}{l}\text { Face-to-face } \\
\text { (group) }\end{array}$ & $\begin{array}{l}\text { Deficiency } \\
\text { intervention }\end{array}$ & $\begin{array}{c}2 \text { short homework tasks } \\
(2 \text { weeks and } 2 \text { months } \\
\text { after) }\end{array}$ & (Meyers et al., 2015) \\
\hline $2 \times 45 \mathrm{~min}$ & $\begin{array}{l}\text { Computer- } \\
\text { based } \\
\text { (individual) }\end{array}$ & $\mathrm{PCl}$ & - & (F. Luthans, Avey, \& Patera, 2008) \\
\hline $\begin{array}{c}2 \times 1 h \\
(1 / \text { week })\end{array}$ & $\begin{array}{l}\text { Face-to-face } \\
\text { (group) }\end{array}$ & $\begin{array}{l}\text { Navigating the } \\
\text { College Experience } \\
\text { (similar to PCl) }\end{array}$ & - & (Bauman, 2014) \\
\hline $\begin{array}{c}2 \times 4 h \\
\text { (1 day off) }\end{array}$ & $\begin{array}{l}\text { Face-to-face } \\
\text { (group) }\end{array}$ & $\begin{array}{l}\text { PsyCap components } \\
\text { intervention }\end{array}$ & - & (Larson, 2004) \\
\hline $\begin{array}{c}3 \times 1.5 \mathrm{~h} \\
(6 \text { weeks })\end{array}$ & $\begin{array}{l}\text { Face-to-face } \\
\text { (individual) }\end{array}$ & $\begin{array}{l}\text { Brief Resilience } \\
\text { Coaching } \\
\text { Programme }\end{array}$ & Pre-work activities & $\begin{array}{c}\text { (Sherlock-Storey, Moss, \& Timson, } \\
\text { 2013) }\end{array}$ \\
\hline $\begin{array}{c}3 \times 2 h \\
\text { (consecutive } \\
\text { days) }\end{array}$ & $\begin{array}{l}\text { Face-to-face } \\
\text { (group) }\end{array}$ & $\begin{array}{l}\text { Positive psychology } \\
\text { training intervention }\end{array}$ & - & (Williams, Kern, \& Waters, 2016) \\
\hline $\begin{array}{c}3 \times 4 h \\
(5 \text { weeks) }\end{array}$ & $\begin{array}{l}\text { Face-to-face } \\
\text { (group) }\end{array}$ & JD-R intervention & $\begin{array}{c}\text { Homework tasks } \\
\text { between session } 2 \text { and } \\
3 \text { ( } 4 \text { weeks })\end{array}$ & $\begin{array}{c}\text { (Van Wingerden, Bakker, \& Derks, } \\
\text { 2016) }\end{array}$ \\
\hline $\begin{array}{l}3 \text { sessions } \\
\text { (6 weeks) }\end{array}$ & $\begin{array}{l}\text { Face-to-face } \\
\quad \text { (group) }\end{array}$ & $\begin{array}{l}\text { Personal resources } \\
\text { intervention }\end{array}$ & $\begin{array}{c}\text { Homework tasks } \\
\text { between session } 2 \text { and } \\
3 \text { ( } 4 \text { weeks) }\end{array}$ & $\begin{array}{c}\text { (Van Wingerden, Derks, \& Bakker, } \\
\text { 2017) }\end{array}$ \\
\hline
\end{tabular}




\begin{tabular}{|c|c|c|c|c|}
\hline $\begin{array}{l}3 \text { sessions } \\
\text { (6 weeks) }\end{array}$ & $\begin{array}{l}\text { Face-to-face } \\
\text { (group) }\end{array}$ & $\begin{array}{l}\text { Job crafting } \\
\text { intervention }\end{array}$ & $\begin{array}{c}\text { Homework tasks } \\
\text { between session } 2 \text { and } \\
3 \text { ( } 4 \text { weeks) }\end{array}$ & (Van Wingerden et al., 2017) \\
\hline $\begin{array}{l}3 \text { sessions } \\
(6 \text { weeks })\end{array}$ & $\begin{array}{l}\text { Face-to-face } \\
\text { (group) }\end{array}$ & $\begin{array}{l}\text { Personal resources + } \\
\text { job crafting } \\
\text { intervention }\end{array}$ & $\begin{array}{c}\text { Homework tasks } \\
\text { between session } 2 \text { and } \\
3 \text { ( } 4 \text { weeks })\end{array}$ & (Van Wingerden et al., 2017) \\
\hline $4 \times 1 \mathrm{~h}$ & $\begin{array}{l}\text { Face-to-face } \\
\text { (group) }\end{array}$ & $\begin{array}{c}\text { Health risk } \\
\text { behaviours and } \\
\text { PsyCap intervention }\end{array}$ & $\begin{array}{l}\text { Weekly phone } \\
\text { reminders } \\
\text { (4 weeks) }\end{array}$ & $\begin{array}{c}\text { (Rew, Powell, Brown, Becker, \& } \\
\text { Slesnick, 2017) }\end{array}$ \\
\hline $\begin{array}{l}1 \text { lunch \& } \\
\text { learn } \\
2 \times 45 \mathrm{~min} \\
\text { individual } \\
1 \times 2 \mathrm{~h} \\
\text { seminar }\end{array}$ & $\begin{array}{l}\text { Computer- } \\
\text { based \& face- } \\
\text { to-face }\end{array}$ & $\begin{array}{c}\mathrm{PCT} \\
(\mathrm{PCl}+\text { stress })\end{array}$ & $\begin{array}{l}\text { 4x15min web-based } \\
\text { homework }\end{array}$ & (Hargrove, 2012) \\
\hline $\begin{array}{c}5 \times 1 \mathrm{~h} \\
(10 \text { weeks })\end{array}$ & $\begin{array}{l}\text { Face-to-face } \\
\quad \text { (group) }\end{array}$ & $\begin{array}{l}\text { Program on positive } \\
\text { focus }\end{array}$ & - & $\begin{array}{c}\text { (Harty, Gustafsson, Björkdahl, \& } \\
\text { Möller, 2016) }\end{array}$ \\
\hline $\begin{array}{c}5 \times 1 \mathrm{~h} \\
(10 \text { weeks })\end{array}$ & $\begin{array}{l}\text { Face-to-face } \\
\quad \text { (group) }\end{array}$ & $\begin{array}{l}\text { Program on } \\
\text { constructive } \\
\text { problem-solving }\end{array}$ & - & (Harty et al., 2016) \\
\hline $\begin{array}{c}8 \times 2 h \\
(2 \text { months })\end{array}$ & $\begin{array}{l}\text { Face-to-face } \\
\text { (group) }\end{array}$ & PCDTI & - & (Kalman \& Summak, 2017) \\
\hline $\begin{array}{c}20 \times 2 \\
(10 \text { weeks })\end{array}$ & $\begin{array}{l}\text { Face-to-face } \\
\quad \text { (group) }\end{array}$ & $\begin{array}{c}\text { Career development } \\
\text { intervention based in } \\
\text { PsyCap }\end{array}$ & - & (Babinchak, 2012) \\
\hline $\begin{array}{c}\text { No } \\
\text { information }\end{array}$ & $\begin{array}{l}\text { Face-to-face } \\
\text { (group) }\end{array}$ & RET & - & $\begin{array}{c}\text { (Demerouti, Eeuwijk, Snelder, \& } \\
\text { Wild, 2011) }\end{array}$ \\
\hline
\end{tabular}

Format of the sessions. Two frequent practitioner and scholars' questions are addressed in our integrative review: "How many participants?" and "Face-to-face or web-based?" As table 4 shows, most of the interventions reviewed (84\%) were conducted in group sessions, whereas only $16 \%$ of the interventions followed the individual format. Except for the coaching and reading programme (Sherlock-Storey et al., 2013; Zhang et al., 2014), the majority of the individual PsyCap development studies were computer or web-based interventions, a suitable intervention for the individual approach (Griffith, 2010; Hargrove, 2012; F. Luthans, Avey, \& Patera, 2008). PsyCap development in group sessions was mostly conducted in non-real work units (e.g. randomized or created experimental groups), and the group size ranged from small groups (5-10 participants) to medium groups (around 30 participants).

Transfer training approaches. The main goal of $\mathrm{POB}$ training intervention is not only to obtain changes immediately after the intervention, but also to ensure that positive resources acquired during training will be useful in daily work life, in order to really become an organizational competitive edge (Nielsen, Randall, \& Christensen, 
2015). According to this proposal and related to the follow-up methodology explained above (Bauman, 2014; Dello Russo \& Stoykova, 2015; Harty et al., 2016; Meyers \& Van Woerkom, 2017; Meyers et al., 2015; Reichard et al., 2014; Zhang et al., 2014), some of the reviewed studies designed activities for training transfer. We found three different strategies to extend the results of the PsyCap intervention. As table 4 shows, the most widely utilized strategy was planning short daily or weekly follow-up "homework" tasks to develop PsyCap in daily work life. These activities were performed between the intervention sessions (Meyers et al., 2015; Van Wingerden et al., 2017) or when all the sessions had ended (Hargrove, 2012; Hodges, 2010; Meyers \& Van Woerkom, 2017), and they were based on reinforcing and practicing the PsyCap contents learned during the sessions (i.e. specific behaviours and cognitions). Electronic devices were utilized by some of these studies reviewed, such as a webbased "homework" format (Hargrove, 2012) or weekly phone reminders to participants (Rew et al., 2017).

Finally, we found one PsyCap intervention study that had not designed postintervention tasks, but instead proposed pre-intervention activities. Sherlock-Storey and colleagues (2013) conducted a brief resilience coaching programme with managers from a public organization. They required participants to complete some workbook activities related to the intervention before the first meeting with the coach assigned to them.

\section{Interventions' efficacy and outcomes}

Micro-interventions' efficacy. As mentioned above, PsyCap intervention designs differ in duration. Based on the state-like property of PsyCap, $\mathrm{PCl}$ was initially established as a micro-intervention, a highly focused and very short strategy to develop PsyCap (F. Luthans, Avey, et al., 2006). Micro-interventions for PsyCap development are a highly cost-effective tool for HRD practitioners and managers that might lead organizations towards a culture of health and resilience (Salanova, Llorens, Cifre, \& 
Martínez, 2012). However, HRD scholars and practitioners might wonder whether PCI or similar PsyCap micro-interventions are really effective (F. Luthans \& YoussefMorgan, 2017). Our integrative review addresses this crucial issue for POB.

As table 4 shows, most of the PsyCap interventions (58\%) were microinterventions ( 1 or 2 sessions). The average PsyCap increase after these microinterventions was $3.11 \%$, ranging from $-5.60 \%$ (decrease) to $7.50 \%$. Most of them (11) obtained an increase of $2-4 \%$, five obtained an increase of about $5 \%$, and one developed PsyCap in $7.50 \%$. The increase in PsyCap participants' levels was statistically significant[i], except for Bauman (2014). Effect sizes reported were small (Cohen's $d$ ranged from 0.19 to 0.40) (Bauman, 2014; F. Luthans et al., 2010; F. Luthans, Avey, \& Patera, 2008), which is consistent with effect sizes in the Positive Psychology interventions literature (see Bolier and colleagues, 2013, for a positive interventions meta-analysis). However, two micro-interventions reviewed were not as successful at increasing PsyCap participants' levels, which hardly increased $(0.40 \%)$ or even decreased (-5.60\%) (Griffith, 2010; Hodges, 2010). In any case, these unsuccessful results were statistically significant. Extended information about PsyCap effectiveness is presented in table 5 .

Longer interventions' efficacy. We also reviewed interventions that were conducted in more than two sessions. These interventions (42\%) obtained an average increase of $4.56 \%$, ranging from $1.20 \%$ to $8.88 \%$. Two of these longer PsyCap interventions obtained an increase of about 3\%, and two others obtained an increase of about $8 \%$. The rest of the studies $(\mathrm{N}=9)$ reported an increase in participants' PsyCap levels of about 1,2 , or $4 \%$. These interventions again obtained an increase in participants' PsyCap level, and this increase was statistically significant ${ }^{i}$ (except for Hargrove, 2012). Moreover, the study by Van Wingerden et al. (2016) reported a large effect size of the intervention, even when other-rated evaluations were measured 
(Demerouti et al., 2011). Extended information about PsyCap effectiveness appears in table 5.

Ensuring the PsyCap interventions' efficacy. As described above, $62 \%$ of the literature reviewed had between-groups designs and comparisons with a broader exploration of PsyCap development effectiveness. These comparisons were successful in a wide range of studies, both in micro-interventions and longer interventions. As table 5 shows, attending to $\mathrm{PCl}$ or similarly successful comparison studies, Bauman (2014) and Brett C. Luthans and colleagues (2014) obtained high significant differences between the $\mathrm{PCl}$ condition and a control or waiting list condition in university students. In addition, Zhang and colleagues (2014) found that using a brief 30-minute structured reading materials-based PsyCap intervention significantly increased participants' levels of PsyCap, compared to workers who did not participate. Highly significant results were also found in a longer PsyCap intervention. Babinchak (2012) reported a significant development of students' PsyCap levels compared to a waiting list. His career development program consisted of 20 two-hour sessions in 10 weeks.

Moreover, as table 5 reveals, some PsyCap micro-intervention literature did not find significant differences between participants and control groups or a WL condition (or did not report them). Most of this literature $(\mathrm{N}=4)$ carried out $\mathrm{PCl}$ with university students and workers (Ertosun et al., 2015; F. Luthans, Avey, et al., 2006; F. Luthans et al., 2010; F. Luthans, Avey, \& Patera, 2008), whereas three studies correspond to extended PsyCap programs conducted at work, such as positive psychology training intervention (Williams et al., 2016), job crafting training (Van Wingerden et al., 2017), and PCI plus stress management (Hargrove, 2012). However, some of the reviewed research reported inconsistent results. Thus, on the one hand, we found some $\mathrm{PCl}$ or similar studies that reported unsatisfactory effects in group comparison results (Griffith, 2010; Hodges, 2010; Larson, 2004; O' Reilly, 2016). Methodological problems in 
conducting the interventions and ceiling effects due to high baseline levels of PsyCap were discussed by the authors as possible explanations for these negative results. On the other hand, a four-week health risk behaviour and PsyCap intervention did not report satisfactory results when comparing the two conditions (Rew et al., 2017). However, participants in this program were a population at social risk, and it must be kept in mind that PsyCap development was not originally designed for this kind of sample.

PsyCap interventions' durability. As mentioned above, some of the reviewed studies (24\%) reported follow-up measures designed to assess the durability of the PsyCap intervention effects. The results reported in this literature generally support the long-term effects of PsyCap micro and longer interventions, measured in a range from 2 weeks to 6 months. Bauman (2014) measured PsyCap two weeks after a microintervention ended and found that participants' levels of PsyCap remained at the baseline level. However, the waiting list levels significantly decreased $(5.8 \%, p<.01)$, and this difference between groups was highly significant $\left(p<.05, \eta^{2} p=.18\right)$, confirming the post-intervention results. Additionally, other researchers performed the follow-up measure one month after the last training session. For example, two microinterventions showed maintenance of participants' PsyCap levels obtained after the program finished (Dello Russo \& Stoykova, 2015; Meyers \& Van Woerkom, 2017). These results were confirmed in between comparisons; significant differences with small size effects were found between experimental and WL conditions $(p<.05, d=$ .34) (Dello Russo \& Stoykova, 2015) and $\left(p<.05, \eta^{2} p=.05\right)$ (Meyers \& Van Woerkom, 2017). Additionally, at the one month follow-up of a longer intervention (Rew et al., 2017), PsyCap levels continued to increase in the experimental condition, but the WL also reported a similar increase. 
Table 5. PsyCap after intervention efficacy

\begin{tabular}{|c|c|c|c|c|}
\hline Study & $\%$ increase PsyCap ${ }^{a}$ & Effect size ${ }^{a}$ & $\%$ increase PsyCap components ${ }^{a}$ & $\begin{array}{c}\text { Between groups PsyCap comparison } \\
\text { effects }^{b}\end{array}$ \\
\hline \multirow[t]{2}{*}{ (Larson, 2004) } & $\mathrm{NR}^{\mathrm{c}}$ & NR & $\begin{array}{l}1.32(\mathrm{SE}) \\
-0.76(\mathrm{HO}) \\
-2.62(\mathrm{OP}) \\
0.35 \text { (RE) }\end{array}$ & $\begin{array}{l}\text { Exp. PsyCap decrease } \\
\text { WL PsyCap increase }\end{array}$ \\
\hline & $3.00^{d}$ & NR & NR & Control no increase $^{d}$ \\
\hline \multirow{2}{*}{$\begin{array}{c}\text { (F. Luthans, Avey, Avolio, Norman, \& Combs, 2006) } \\
\text { (F. Luthans, Youssef, \& Avolio, 2007) } \\
\text { (F. Luthans, Youssef-Morgan, \& Avolio, 2015) }\end{array}$} & $3.00^{d}$ & NR & NR & - \\
\hline & $2.00^{\mathrm{d}}$ & NR & NR & - \\
\hline $\begin{array}{l}\text { (F. Luthans, Avey, \& Patera, 2008) } \\
\text { (F. Luthans et al., 2015) }\end{array}$ & $2.40^{*}$ & 0.19 & NR & Control decrease $1.00 \%{ }^{\mathrm{e}}$ \\
\hline (Griffith, 2010) & $-5.60^{e}$ & NR & NR & Control decrease $4.00 \%$ \\
\hline (Hodges, 2010) & 0.40 & NR & NR & $\begin{array}{l}\text { WL1 increase } 1.40 \% \\
\text { WL2 decrease } 0.60 \%^{*}\end{array}$ \\
\hline \multirow{2}{*}{$\begin{array}{l}\text { (F. Luthans, Avey, Avolio, \& Peterson, 2010) } \\
\text { (F. Luthans et al., 2015) }\end{array}$} & $4.00^{\star \star}$ & 0.40 & NR & Control increase $0.40 \%^{\mathrm{e}}$ \\
\hline & $2.80^{\star \star}$ & 0.31 & NR & - \\
\hline (Demerouti, Eeuwijk, Snelder, \& Wild, 2011) & $8.88^{\star \star \star}$ & 0.89 & $\begin{array}{c}11.00^{\star \star \star}(d=0.85)(\mathrm{SE}) \\
9.44^{\star \star \star}(d=0.74)(\mathrm{HO}) \\
6.44^{\star \star \star}(d=0.58)(\mathrm{OP}) \\
8.44^{* \star \star}(d=0.57)(\mathrm{RE}) \\
8.16^{\mathrm{e}}(\mathrm{SE})\end{array}$ & - \\
\hline (Babinchak, 2012) & $8.20^{\circ}$ & NR & $\begin{array}{l}11.67^{\mathrm{e}}(\mathrm{HO}) \\
8.43^{\mathrm{e}}(\mathrm{OP}) \\
4.56^{\mathrm{e}}(\mathrm{RE})\end{array}$ & WL decrease $2.03 \%^{\star * \star}\left(\eta^{2} p=.11\right)$ \\
\hline (Hargrove, 2012) & 1.20 & NR & NR & WL decrease $0.04 \%^{\mathrm{e}}$ \\
\hline
\end{tabular}


(Sherlock-Storey, Moss, \& Timson, 2013)

(Bauman, 2014)

(Dello Russo, 2014)

(Dello Russo \& Stoykova, 2015)

(B. C. Luthans, Luthans, \& Avey, 2014)

(Reichard, Dollwet, \& Louw-Potgieter, 2014)

(Zhang, Li, Ma, Hu, \& Jiang, 2014)

(Diedrich, 2015)

(Ertosun, Erdil, Deniz, \& Alpkan, 2015)

(Meyers, Van Woerkom, De Reuver, Bakk, \& Oberski, 2015)

(Bell, 2016)

(Gutierrez, 2016)

6.25 (SE)

$8.75^{*}(\mathrm{HO})$
$1.87^{\star}(\mathrm{OP})$

$11.87^{*}(\mathrm{OP})$
$6.87^{*}(\mathrm{RE})$

\section{NR}

$7.60^{\star *}(\mathrm{SE})$ $5.80^{\star *}(\mathrm{HO})$ $6.00^{* *}(\mathrm{OP})$ 3.20 (RE)

NR

NR

NR

NR

NR

NR

$7.75^{\mathrm{e}}(\mathrm{SE})$

$6.86^{\mathrm{e}}(\mathrm{HO})$

$3.00^{\mathrm{e}}$ (OP)

$3.00^{\mathrm{e}}$ (RE)

$3.75^{\mathrm{e}}(\mathrm{SE})$

$2.71^{\mathrm{e}}(\mathrm{HO})$

$4.75^{\mathrm{e}}$ (OP)

$4.75^{\circ}(\mathrm{OP})$

$15.25^{\mathrm{e}}$ (SE)

$15.25^{\circ}$ (SE)

$8.43^{\mathrm{e}}$ (RE)

NR
WL decrease $2.20 \%^{\star \star *}\left(\eta^{2} p=.29\right)$

\section{NR}

Control increase $0.60 \%$ **

WL decrease $0.40 \%^{\star \star \star}$

\section{WL increase $4.34 \%$}


(Harty, Gustafsson, Björkdahl, \& Möller, 2016)

(O' Reilly, 2016)

(Van Wingerden, Bakker, \& Derks, 2016)

(Van Wingerden, 2016)

(Williams, Kern, \& Waters, 2016)

(Meyers \& Van Woerkom, 2017)

(Rew, Powell, Brown, Becker, \& Slesnick, 2017)

(Van Wingerden, Derks, \& Bakker, 2017)

(Van Wingerden, 2016)
NR

$3.38^{\mathrm{e}}$

$3.00^{\circ}$

$* \star c d$

$2.92^{e}$

$4.34^{*}$
NR

NR

NR

NR

NR

$\left(\eta^{2} p=.27\right)$ $16.66^{\star * *}(\mathrm{SE})$

$-0.38(\mathrm{HO})$

$8.33(\mathrm{OP})$

$11.66^{\star \star}(\mathrm{SE})$

$1.63(\mathrm{HO})$

2.08 (OP)

$0.67^{\mathrm{e}}(\mathrm{SE})$

$8.10^{\mathrm{e}}(\mathrm{HO})$

$3.80^{\mathrm{e}}(\mathrm{OP})$

$0.00^{\mathrm{e}}(\mathrm{RE})$

NR

NR

NR

NR

$7.87^{\mathrm{e}}(\mathrm{HO})$

$-2.17^{\mathrm{e}}(\mathrm{OP})$

$3.86^{\mathrm{e}}(\mathrm{RE})$

NR

$\left(\eta^{2} p=.17\right)$
NR

NR

NR

Control increase $3.70 \%$

WL decrease $3.64 \%^{* \star}$

WL decrease $0.40 \%$

WL increase $5.72 \%{ }^{\circ}$

WL changes no significant ${ }^{e}$

Note. ${ }^{*} \mathrm{p}<.05 ;{ }^{* *} \mathrm{p}<.01 ;{ }^{* \star *} \mathrm{p}<.001 ;$ Exp. $=$ experimental condition (PsyCap intervention group); HO = hope; NR = information not reported; OP $=$ optimism; RE $=$ resilience; SE = self-efficacy; WL $=$ waiting list.

a PsyCap condition: \% increase and intervention effect size based on repeated (pre, post) within-group punctuations (effect size reported as Cohen's $d$ unless otherwise stated).

${ }^{b}$ Comparison between-groups based on time (pre, post) and condition (experimental vs. WL/Control) core PsyCap punctuations.

${ }^{c}$ Unable to calculate the \% PsyCap changes due to type of punctuations reported.

${ }^{\mathrm{d}}$ Preliminary research / Data analyses not reported.

e Information about significance not reported. 
Regarding longer follow-up research designs, Reichard and colleagues (2014) measured PsyCap between one and two months after their cross-cultural PsyCap micro-intervention ended. They found that participants' PsyCap levels remained higher than baseline $(p<.01)$, even though the scores were lower than in the post measurement. The same results were found by Zhang and colleagues (2014) in a three-month follow-up; furthermore, they found large significant differences between participants in their short reading intervention and the WL $(p<.01)$. Additionally, a sixmonth follow-up study of a ten-week program on constructive problem-solving reported higher levels of participants' PsyCap compared to baseline (Harty et al., 2016).

Finally, the study by Meyers et al. (2015) reported two different follow-up measures at the first and third month, where PsyCap levels of participants showed a "rollercoaster" pattern. They increased after the micro-intervention, started to decrease one month later, and finally reached the highest scores at the third month. These results are consistent with PsyCap's definition as state-like and developable (F. Luthans, Youssef, et al., 2007).

PsyCap interventions and positive outcomes. As described above, some of the PsyCap intervention literature reviewed aimed not only to enhance participants' PsyCap levels, but also to obtain positive work-related outcomes. For example, some of the studies reviewed were designed to increase employees' performance, either selfreported or manager-rated. In both micro and longer interventions, in-role self-reported performance was positively developed. Van Wingerden and colleagues (2016) found a significant increase of $1.75 \%$ in participants' performance compared to a WL $(p<.05)$ after a five-week JD-R intervention. Zhang and colleagues (2014) conducted a short reading intervention and found a significant increase of $3.8 \%$ in participants' performance, compared to a WL $(p<.001)$, that remained after three months $(p<.05)$. Extending the self-reported measure of performance, some reviewed literature combines self-reported measures with manager-ratings, showing increases in both 
measures (Hodges, 2010; F. Luthans et al., 2010). Moreover, Luthans and his team reported high and significant increase in participants' self-reported performance $(10.89 \%, p<.01, d=.96)$ and a small and significant increase in manager-rated performance $(6 \%, p<.05, d=.35)$.

In addition to job performance enhancement, three studies aimed to increase positive job attitudes. Demerouti and colleagues (2011) found a high significant increase in levels of assertiveness after participating in a RET program, both selfreported $(14.6 \%, p<.001, d=1.27)$ and other-rated $(9.55 \%, p<.001, d=0.85)$. Reichard and colleagues (2014) reported a high significant increase in participants' cultural intelligence after a cross-cultural PsyCap micro-intervention (4.25\%, $p<.001)$, and it remained two months later $(4 \%, p<.01)$. They also reported a decrease in levels of negative attitudes, such as ethnocentrism at work, at both the post $(3.60 \%, p<.001)$ and follow-up measures (1.6\%). Similar positive effects were found after a brief resilience coaching programme, which achieved a $10.93 \%(p<.01)$ increase in readiness for organizational change (Sherlock-Storey et al., 2013).

The PsyCap intervention literature also aims to improve employees' health and well-being at work. Regarding engagement, the literature reviewed reported inconsistent results. A longer, general positive resources intervention obtained an increase of $5.83 \%$ in engagement, which was significantly different from a WL ( $p$ <.01) (Van Wingerden et al., 2016). However, two PsyCap micro-interventions did not obtain positive differences in enhancement of work engagement, compared to the experimental condition and WL (Hodges, 2010; Meyers \& Van Woerkom, 2017). Similar positive and successful results have been found with job satisfaction (4\% increase), positive emotions $(10.6 \%, p<.001)$, and work happiness $(1 \%)$ (Harty et al., 2016; Meyers \& Van Woerkom, 2017; Reichard et al., 2014; Williams et al., 2016). Finally, Meyers et al. (2015) reported positive results on a more general well-being measure: personal growth initiative. It showed an increase of about $8.4 \%$ after a 
strengths intervention and about $4.4 \%$ after a deficiency-solving intervention. These results remained stable at 1 - and 3-month follow-up measures.

Additionally, the literature review showed psychological variables and cognitive mechanisms related to the effectiveness of PsyCap interventions, such as participants' levels of training transfer motivation $(0.5 \%)$ and perceptions of organizational virtues (4.2\%) (Griffith, 2010; Williams et al., 2016). Moreover, participants reported higher levels of positive selective exposure (focus on positive stimulus) than WL members (5\% and $0.18 \%$, respectively) (Williams et al., 2016).

Qualitative data. Additionally, in some of the reviewed articles we found qualitative data that reinforce and complete quantitative information about PsyCap interventions' effectiveness. Primarily, we reviewed a qualitative study on the participants' evaluation of the experience of the intervention (Kalman \& Summak, 2017). Content analysis of semi-structured interviews revealed participants' general satisfaction with the intervention implementation. They found the program to be useful for their personal and professional growth, and they described having higher levels of personal awareness, positive affect, and efficacy in problem-solving after the intervention. Moreover, some of the literature reviewed used a mixed methodology with quantitative and qualitative data. The qualitative data generally confirmed the PsyCap intervention effects found in quantitative research. This literature suggested that participants understood what PsyCap means, and they benefitted from the training transfer of the resources developed to their daily work lives. They reported positive changes at work, feeling more positive emotions and facing difficulties with a more positive approach by being more aware of their personal resources (Diedrich, 2015; Hargrove, 2012; Harty et al., 2016; Hodges, 2010; Van Wingerden et al., 2017). 


\section{Conclusions}

The purpose of the present integrative review was to analyse the literature on PsyCap interventions in order to synthesize the procedures, methodologies, effectiveness, and outcomes published on POB to date. Our conclusions shed light on PsyCap intervention research and can help HRD professionals to decide whether and how to implement PsyCap interventions. We analysed and synthesized the literature focusing on the research and intervention procedures, and we synthesized the main results obtained after conducting the PsyCap interventions, in terms of efficacy and outcomes. Below, we present the main conclusions, and we highlight needs and opportunities for further research on PsyCap interventions. For a more comprehensive view, the future agenda and main conclusions are summarized in figure 1.

Based on PsyCap theory and basic literature, the PsyCap intervention research reviewed generally confirmed that PsyCap is positive, state-like, developable, and related to positive outcomes. Generally, the studies reviewed found increases in participants' PsyCap levels after the interventions that were also statistically significant with a broad range of effect sizes. All of the studies were conducted in a real context, and so researchers used quasi-experimental designs with small samples of participants. It has been proposed that significance might be influenced by these small sample sizes (Cumming, 2014; Faber \& Fonseca, 2014). Further research should investigate PsyCap interventions, improving statistical power and significance. Two strategies could be useful: using larger sample sizes and using different methodologies for the traditional analysis of variance, such as longitudinal growth models (Moskowitz et al., 2017). Furthermore, some of the literature reviewed did not report precise data about statistically significant differences and effect sizes. We agree with Yuan, Liu, Tang, and Zhang (2014) that POB and HRD need empirical evidence based on more rigorously controlled experimental research. 
PsyCap development related to interventions has also been confirmed by comparing participants' improvements to a waiting list group (WL) that did not receive the developmental intervention, or a control group that received alternative interventions, such as decision making training, information sessions, or team-building and leadership development. However, these group comparison studies were the minority, and the results were not very consistent. Thus, we agree with Reichard and colleagues' call for research (2014) with the convenience of adding comparison groups in the PsyCap intervention research, in order to enhance the internal validity of the results obtained.

This integrative review also provides information about the sustainability of PsyCap development. A few of the studies reviewed (24\%) performed follow-up measures to test long-term effects of the PsyCap interventions. Results did not lead to robust conclusions about the sustainability of the effects, and there were large discrepancies between the studies' follow-up measures, ranging from 2 weeks to 6 months. Moreover, researchers are concerned about determining the sustainability of PsyCap development through longitudinal research designs and analyses, suggesting the need for future follow-up studies with measurements after 1, 3, and/or 6 months, or even after a whole year (Dello Russo \& Stoykova, 2015; Meyers \& Van Woerkom, 2017; O' Reilly, 2016; Rew et al., 2017; Yuan et al., 2014). However, PsyCap is defined as a state-like positive resource, and we wonder if examining the long-term effects of PsyCap development through an intervention is really consistent with this state-like conception. We agree with proposals made in a recent PsyCap literature review (F. Luthans \& Youssef-Morgan, 2017), and we think that further theoretical reflections and proposals must be elaborated by POB and HRD scholars in order to shed light on this issue. Future research on sustaining PsyCap intervention effects might focus on training transfer, testing strategies like using positive resources in the work place, and receiving reminders from HRD practitioners. 
Another important characteristic that defines PsyCap is its higher-order property. Most of the studies addressed the PsyCap core approach, but some of the literature conducted interventions to develop its components separately (i.e. selfefficacy, hope, optimism, and resilience). According to Fred Luthans and Carolyn Youssef-Morgan (2017), in order to investigate the convergent and discriminant validity of the PsyCap components, it is important to examine the psychological processes that PsyCap components have in common, but also to determine how different profiles of hope, self-efficacy, optimism, and resilience may affect the intervention outcomes. In this regard, it has been proposed that the four factors of PsyCap share cognitive coping mechanisms (Dawkins et al., 2013), and some coping strategies have been added to PsyCap interventions (Harty et al., 2016; Kalman \& Summak, 2017). Furthermore, it has been demonstrated that coping strategies aimed to reframe negative events into positive stimulus mediate the relationship between PsyCap and positive outcomes of satisfaction and performance (Ortega-Maldonado \& Salanova, 2017).

Moreover, we detected some key strategies used to develop PsyCap components that are related to coping skills. This is case of pathways generation to foresee solutions for future obstacles (hope training), the ABCDE rational process to objectively analyse and overcome setbacks (optimism training), ideal cognitive and affective reactions when problems appear (resilience training), and task mastery even in adversity (self-efficacy training). Regarding the theoretical and practical relationship between PsyCap and coping skills, and the role of positive psychological states in the stress and coping process (Folkman, 2008), we propose the need for further research to investigate whether coping strategies influence PsyCap development. Likewise, future research on PsyCap might compare interventions on PsyCap's core construct and on its separate components. Moreover, as proposed, future research should also examine whether the development of the four components is necessary in order to 
increase PsyCap levels (Dawkins \& Martin, 2014; Gutierrez, 2016; F. Luthans \& Youssef-Morgan, 2017).

The PsyCap interventions mainly measured PsyCap through the self-reported PCQ-24, and we found no studies that used shorter versions of this questionnaire (Dawkins et al., 2013). However, PsyCap measures to monitor intervention effects are a current topic of interest and debate among $\mathrm{POB}$ scholars and practitioners (F. Luthans \& Youssef-Morgan, 2017). Some researchers call for collecting data using other strategies in conjunction with self-reported measures of PsyCap (F. Luthans et al., 2010), such as other-rated measures and/or calculating the self-other agreement (Demerouti et al., 2011). Triangulating results with secondary measures may be a more complete and robust strategy to avoid response bias and enhance the validity of the findings (Babinchak, 2012; B. C. Luthans et al., 2014). Comparing quantitative data to alternative measures of PsyCap, such as qualitative measures (e.g. observation, reflexive writing, focus group discussions) (Kalman \& Summak, 2017), or even implicit measures (Williams, Kern, \& Waters, 2017), are some proposals that emerge from our PsyCap intervention literature and correspond to gaps in the PsyCap research (F. Luthans, 2012; F. Luthans \& Youssef-Morgan, 2017). Additionally, some studies used a combination of measures of PsyCap components, which could be quite risky in terms of construct validity if the items conceptualize the component as a trait-like dimension (Demerouti et al., 2011; F. Luthans \& Youssef-Morgan, 2017).

\section{Future agenda}

PsyCap intervention research is an incipient topic that is now sufficiently mature to address some necessary future challenges for high quality evidence-based HRD and POB practice. As figure 1 shows, there are some gaps in the literature that should be addressed in further research. 
First, PsyCap is theoretically and empirically related to positive personal and organizational outcomes (F. Luthans \& Youssef-Morgan, 2017). However only a few of the studies reviewed examined these positive effects. Successful effects were found on performance (self-reported and manager-rated), positive attitudes (assertiveness, cultural intelligence, and readiness for organizational change), a decrease in negative attitudes (ethnocentrism at work), work well-being (engagement, job satisfaction, work happiness, and positive affect), and whole life well-being (personal growth initiative).

Second, unsuccessful effects were found on objective performance, social connectedness (positive attitude), job crafting behaviours, decreasing burnout (work well-being), and life satisfaction and a future time perspective (whole life well-being). These limited results bring new opportunities for future POB and HDR research because there is ample empirical evidence indicating that PsyCap is a powerful predictor of many important desired and undesired organizational attitudes and behaviours (Avey et al., 2011; F. Luthans et al., 2015; Newman et al., 2014).

Third, the organizational interventions literature highlights training transfer as a crucial factor for ensuring effectiveness (Nielsen et al., 2015), and some PsyCap researchers have suggested that providing new opportunities to apply new skills may be a mediator between PsyCap development and an increase in positive outcomes (Dello Russo \& Stoykova, 2015; Larson, 2004). Only a minority of the PsyCap interventions literature carried out strategies to extend the time frame for participants to transfer the resources acquired during training to their work tasks. Strategies such as between and/or post session "homework" training, or sending messages by electronic devices to remind participants of the contents, have been examined (Rew et al., 2017). Furthermore, training transfer motivation has been empirically and theoretically related to PsyCap development (Griffith, 2010; F. Luthans \& Youssef-Morgan, 2017), and so we call for future research on the role of transfer as a mediator between PsyCap development and positive outcomes. 
Fourth, PsyCap researchers are also concerned about better understanding the value of different strategies aimed at PsyCap development and their subsequent influence on positive outcomes (Gutierrez, 2016; Kalman \& Summak, 2017; Newman et al., 2014). In this integrative review, we have compared micro and longer intervention results. Both procedures increased PsyCap in similar percentages, but effects of longer interventions were larger and seemed to be more sustained. Future reviews and meta-analyses may complete our results and shed light on PsyCap microinterventions' effectiveness. Furthermore, some PsyCap intervention strategies focused on the synergetic development of its components ( $\mathrm{PCl}$ or similar), but there were also interventions that added positive resources to the PsyCap intervention, such as happiness, stress management, control of health risk behaviours, or cross-cultural interactions (Hargrove, 2012; Hodges, 2010; Reichard et al., 2014; Rew et al., 2017). Moreover, some researchers decided to increase PsyCap through psychotherapy (RET) (Demerouti et al., 2011) or general positive interventions, such as strengths development, personal resources training, positive focus and constructive problemsolving, job crafting, coaching, and personal branding (Bell, 2016; Harty et al., 2016; Meyers \& Van Woerkom, 2017; Meyers et al., 2015; Sherlock-Storey et al., 2013; Van Wingerden et al., 2016, 2017). Future research should focus on evaluating and comparing the effectiveness of these different strategies. Likewise, we found successful individual computer-based or real team workgroup interventions. These strategies were not compared to the face-to-face small-groups procedure, indicating a gap on the literature. In conclusion, we suggest that the procedure and design of the intervention may influence the efficacy of PsyCap interventions. Specifically, we propose that procedures oriented toward training transfer may mediate the successful relationship between PsyCap development and positive outcomes, showing the need to examine these different intervention strategies and the associated psychological processes (Kalman \& Summak, 2017; Williams et al., 2016). 


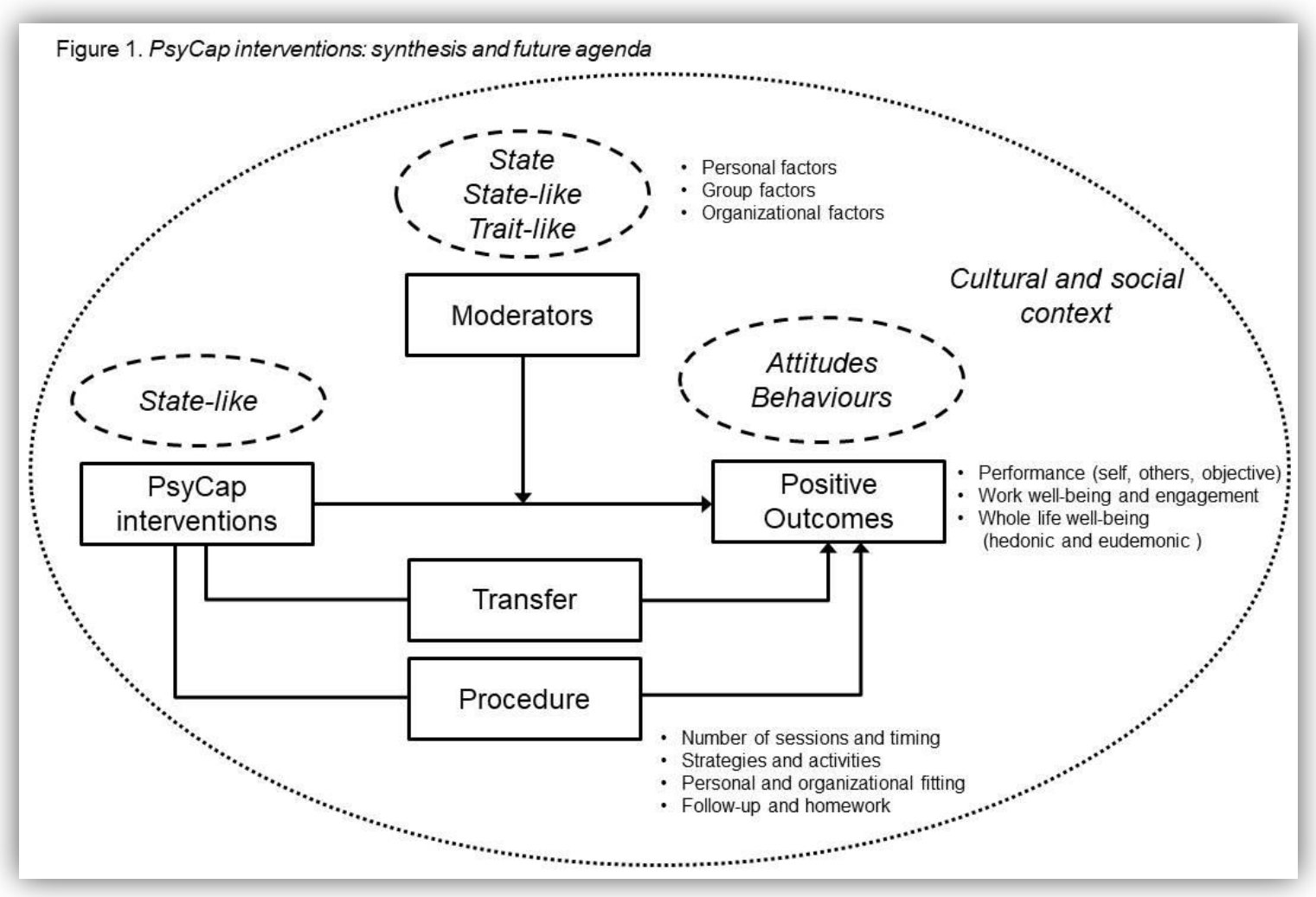

Fifth, PsyCap researchers are also concerned about exploring the potential influence of individual, organizational, and contextual moderators in assessing the efficacy of PsyCap interventions (Dawkins \& Martin, 2014; Ertosun et al., 2015; Hodges, 2010; Meyers et al., 2015). It has been proposed that participants' personal factors along the state-trait continuum, such as positive affect, motivation, personal strengths, experience, or personality, may moderate the effectiveness of PsyCap interventions and their desired outcomes. Furthermore, participants' PsyCap levels before the intervention have been found to moderate $\mathrm{PCl}$ effects, showing higher effects in participants with lower initial PsyCap levels (F. Luthans et al., 2010). In contrast, several studies showed ceiling effects that negatively affected PsyCap development (Griffith, 2010; Hargrove, 2012; Hodges, 2010), suggesting that positive organizational culture and climate may moderate the intervention efficacy (Larson, 2004; F. Luthans \& Youssef-Morgan, 2017). Positive organizations generate positive spirals (Salanova, Llorens, \& Schaufeli, 2011), which may influence positive interventions, either buffering their efficacy or limiting it due to a possible ceiling effect. Further research is needed to resolve this question. Likewise, group and organizational 
factors have been proposed as moderators in PsyCap interventions. For example, Diedrich (2015) called for examining whether increases in leaders' PsyCap benefit PsyCap stakeholders' development.

Finally, cultural and societal settings are important factors to consider in POB and HRD (F. Luthans \& Youssef-Morgan, 2017). The PsyCap intervention literature presented studies on employees, supervisors, students, and unemployed people across different countries and different financial sectors and types of work. However, the majority of the research took place in the USA, and cultural differences have been found to be important in PsyCap interventions (Zhang et al., 2014). Therefore, for greater external validity of the PsyCap intervention research, we suggest further developing research on cultural differences.

December 2017. Psychological capital development emerges as a direct route to higher performance and well-being at work. In the new socioeconomic era, contemporary organizations are not and will not be the same: they will be healthier and more successful in the future. Achieving this goal lies in the hands of POB and HRD scholars and practitioners, and we have the necessary PsyCap to make this a reality. We cannot wait any longer.

\section{References}

Abbas, M., \& Raja, U. (2015). Impact of psychological capital on innovative performance and job stress. Canadian Journal of Administrative Sciences / Revue Canadienne Des Sciences de l'Administration, 32(2), 128-138. https://doi.org/10.1002/cjas.1314

Avey, J. B., Luthans, F., \& Jensen, S. M. (2009). Psychological Capital: a positive resource for combating employee stress and turnover. Human Resource Management, 48(5), 677-693. https://doi.org/10.1002/hrm 
Avey, J. B., Luthans, F., Smith, R. M., \& Palmer, N. F. (2010). Impact of positive psychological capital on employee well-being over time. Journal of Occupational Health Psychology, 15(1), 17-28. https://doi.org/10.1037/a0016998

Avey, J. B., Luthans, F., \& Youssef, C. M. (2010). The Additive Value of Positive Psychological Capital in Predicting Work Attitudes and Behaviors. Journal of Management, 36(2), 430-452. https://doi.org/10.1177/0149206308329961

Avey, J. B., Patera, J. L., \& West, B. J. (2006). The Implications of Positive Psychological Capital on Employee Absenteeism. Journal of Leadership \& $\begin{array}{llr}\text { Organizational } & \text { Studies, }\end{array}$ https://doi.org/10.1177/10717919070130020401

Avey, J. B., Reichard, R. J., Luthans, F., \& Mhatre, K. H. (2011). Meta-analysis of the impact of positive psychological capital on employee attitudes, behaviors, and performance. Human Resource Development Quarterly, 22(2), 127-152. https://doi.org/10.1002/hrdq.20070

Avey, J. B., Wernsing, T. S., \& Luthans, F. (2008). Can Positive Employees Help Positive Organizational Change? Impact of Psychological Capital and Emotions on Relevant Attitudes and Behaviors. The Journal of Applied Behavioral Science, 44(1), 48-70. https://doi.org/10.1177/0021886307311470

Babinchak, J. A. (2012). The impact of an intervention on the psychological capital levels of career college learners a quasi-experimental study. Capella Univesity, US.

Bandura, A. (1997). Self-effi cacy: The exercise of control. New York: Freeman.

Baron, R. A., Franklin, R. J., \& Hmieleski, K. M. (2013). Why Entrepreneurs Often Experience Low, Not High, Levels of Stress: The Joint Effects of Selection and Psychological Capital. Journal of Management, 20(10), 1-27. https://doi.org/10.1177/0149206313495411 
Bauman, L. V. (2014). The impact of a psychological capital intervention on college student well-being. Azusa Pacific University, US.

Bell, J. J. (2016). Personal Branding: Impacts on coaching military veterans. Benedictine University, US.

Bolier, L., Haverman, M., Westerhof, G. J., Riper, H., Smit, F., \& Bohlmeijer, E. (2013). Positive psychology interventions: a meta-analysis of randomized controlled studies. BMC Public Health, 13(1), 119. https://doi.org/10.1186/1471-2458-13-119

Choi, Y., \& Lee, D. (2014). Psychological capital, Big Five traits, and employee outcomes. Journal of Managerial Psychology, 29(2), 122-140. https://doi.org/10.1108/JMP-06-2012-0193

Culbertson, S. S., Fullagar, C. J., \& Mills, M. J. (2010). Feeling good and doing great: The relationship between psychological capital and well-being. Journal of Occupational Health Psychology, 15(4), 421-433. https://doi.org/10.1037/a0020720

Cumming, G. (2014). The New Statistics: Why and How. Psychological Science, 25(1), 7-29. https://doi.org/10.1177/0956797613504966

Dawkins, S., \& Martin, A. (2014). Enhancing the psychological capital of teams: Adapting an individual-level intervention for multi-level delivery and evaluation. In R. J. Burke \& A. M. Richardsen (Eds.), Corporate wellness programs: Linking employee and organizational health (pp. 79-100). Northampton, MA, US: Edward Elgar Publishing. https://doi.org/http://dx.doi.org/10.4337/9781783471706.00013

Dawkins, S., Martin, A., Scott, J., \& Sanderson, K. (2013). Building on the positives: A psychometric review and critical analysis of the construct of Psychological Capital. Journal of Occupational and Organizational Psychology, 86(3), 348-370. https://doi.org/10.1111/joop.12007 
Dello Russo, S. (2014). Psychological Capital Intervention (PCI): A Replication and Extension. In // Congreso Nacional de Psicología Positiva. Oropesa del Mar, Spain.

Dello Russo, S., \& Stoykova, P. (2015). Psychological Capital Intervention (PCI): A Replication and Extension. Human Resource Development Quarterly, 26(3), 329_ 347. https://doi.org/10.1002/hrdq

Demerouti, E., Eeuwijk, E. Van, Snelder, M., \& Wild, U. (2011). Assessing the effects of a "personal effectiveness" training on psychological capital, assertiveness and self-awareness using self-other agreement. Career Development International, 16(1), 60-81. https://doi.org/10.1108/13620431111107810

Diedrich, T. (2015). Psychological capital: An intervention method for developing organization leadership in a mental health center. Benedictine University, US.

Ertosun, Ö. G., Erdil, O., Deniz, N., \& Alpkan, L. (2015). Positive Psychological Capital Development: A Field Study by the Solomon Four Group Design. International Business Research, 8(10), 102-111. https://doi.org/10.5539/ibr.v8n10p102

Faber, J., \& Fonseca, L. M. (2014). How sample size influences research outcomes. Dental Press Journal of Orthodontics, 19(4), 27-29. https://doi.org/10.1590/21769451.19.4.027-029.ebo

Folkman, S. (2008). The case for positive emotions in the stress process. Anxiety, Stress, and Coping, 21(1), 3-14. https://doi.org/10.1080/10615800701740457

Griffith, J. N. (2010). The influence of pre-training positive psychological capital development on training motivation. University of Nebraska - Lincoln, US.

Gutierrez, J. C. P. (2016). Evaluación De Una Práctica Para El Desarrollo Del Capital Psicológico. Revista Orbis, 12(34), 4-26. Retrieved from https://search.proquest.com/docview/1912199292?accountid=38885 
Hargrove, M. B. (2012). Antecedents and outcomes associated with the individual stress response. U Texas at Arlington, US.

Harty, B., Gustafsson, J. A., Björkdahl, A., \& Möller, A. (2016). Group intervention: A way to improve working teams' positive psychological capital. Work: Journal of Prevention, Assessment \& Rehabilitation, 53(2), 387-398. https://doi.org/10.3233/WOR-152227

Hervás, G., \& Vázquez, C. (2013). Construction and validation of a measure of integrative well-being in seven languages: the Pemberton Happiness Index. Health and Quality of Life Outcomes, 11, 66. https://doi.org/10.1186/1477-7525$11-66$

Hodges, T. D. (2010). An experimental study of the impact of psychological capital on performance, engagement, and the contagion effect. U Nebraska - Lincoln, US.

Kalman, M., \& Summak, M. S. (2017). Revitalizing the HERO within Teachers: An Analysis of the Effects of the PsyCap Development Training. The Qualitative Report, 22(3), 655-682.

Kraaijenbrink, J., Spender, J.-C., \& Groen, A. J. (2010). The Resource-Based View: A Review and Assessment of Its Critiques. Journal of Management, 36(1), 349-372. https://doi.org/10.1177/0149206309350775

Larson, M. D. (2004). Positive psychological capital: A comparison with huam and social capital and an analysis of a training intervention. University of Nebraska Lincoln, US.

Larson, M. D., \& Luthans, F. (2006). Potential Added Value of Psychological Capital in Predicting Work Attitudes. Journal of Leadership \& Organizational Studies, 13(2), 75-92. https://doi.org/10.1177/10717919070130020601 
Le Blanc, P. M., \& Oerlemans, W. G. M. (2016). Amplition in the Workplace: Building a Sustainable Workforce Through Individual Positive Psychological Interventions. Psychologist Papers, 37(3), 185-191.

Liu, Y. (2013). Mediating effect of positive psychological capital in Taiwan's life insurance industry. Social Behavior and Personality, 41(1), 109-112. https://doi.org/10.2224/sbp.2013.41.1.109

Luthans, B. C., Luthans, K. W., \& Avey, J. B. (2014). Building the Leaders of Tomorrow: The Development of Academic Psychological Capital. Journal of Leadership \& Organizational Studies, 21(2), 191-199. https://doi.org/10.1177/1548051813517003

Luthans, B. C., Luthans, K. W., \& Jensen, S. M. (2012). The Impact of Business School Students' Psychological Capital on Academic Performance. Journal of Education for Business, $\quad$ 87(October), 253-259. https://doi.org/10.1080/08832323.2011.609844

Luthans, F. (2012). Psychological capital: Implications for HRD, retrospective analysis, and future directions. Human Resource Development Quarterly, 23(1), 1-8. https://doi.org/10.1002/hrdq.21119

Luthans, F., Avey, J. B., Avolio, B. J., Norman, S. M., \& Combs, G. M. (2006). Psychological capital development: toward a micro-intervention. Journal of Organizational Behavior, 27, 387-393.

Luthans, F., Avey, J. B., Avolio, B. J., \& Peterson, S. J. (2010). The Development and Resulting Performance Impact of Positive Psychological Capital. Human Resource Development Quarterly, 21(1), 41-67. https://doi.org/10.1002/hrdq

Luthans, F., Avey, J. B., Clapp-Smith, R., \& Li, W. (2008). More evidence on the value of Chinese workers' psychological capital: A potentially unlimited competitive 
resource? The International Journal of Human Resource Management, 19(5), 818-827. https://doi.org/10.1080/09585190801991194

Luthans, F., Avey, J. B., \& Patera, J. L. (2008). Experimental Analysis of a Web-Based Training Intervention to Develop Positive Psychological Capital. Academy of Management Learning \& Education, 7(2), 209-221. https://doi.org/10.5465/AMLE.2008.32712618

Luthans, F., Avolio, B. J., Avey, J. B., \& Norman, S. M. (2007). Positive Psychological Capital: Measurement and Relationship with Performance and Satisfaction. Personnel Psychology, 60, 541-572.

Luthans, F., Avolio, B. J., Norman, S. M., \& Avey, J. B. (2006). Psychological capital: measurement and relationship with performance and satisfaction. Lincoln, NE: Gallup Leadership Institute Working Paper.

Luthans, F., Avolio, B. J., Walumbwa, F. O., \& Li, W. (2005). The Psychological Capital of Chinese Workers : Exploring the Relationship with Performance Fred Luthans, Bruce J . Avolio , Fred O . Walumbwa. Management and Organization Review, $1(2), 249-271$.

Luthans, F., Norman, S. M., Avolio, B. J., \& Avey, J. B. (2008). The mediating role of psychological capital in the supportive organizational climate - Employee performance relationship. Journal of Organizational Behavior, 29(2), 219-238. https://doi.org/10.1002/job.507

Luthans, F., \& Youssef-Morgan, C. M. (2017). Psychological Capital: An EvidenceBased Positive Approach. Annual Review of Organizational Psychology and Organizational Behavior, 4(1), 339-366. https://doi.org/10.1146/annurevorgpsych-032516-113324

Luthans, F., Youssef-Morgan, C. M., \& Avolio, B. J. (2015). Psychological Capital and Beyond. New York: Oxford University Press. 
Luthans, F., Youssef, C. M., \& Avolio, B. J. (2007). Psychological Capital: Developing the Human Competitive Edge. Oxford University Press.

Masten, a S. (2001). Ordinary magic. Resilience processes in development. The American Psychologist, 56(3), 227-238. https://doi.org/10.1037/0003066X.56.3.227

Meyers, M. C., \& Van Woerkom, M. (2017). Effects of a Strengths Intervention on General and Work-Related Well-Being: The Mediating Role of Positive Affect. Journal of Happiness Studies, 18(3), 671-689. https://doi.org/10.1007/s10902$016-9745-x$

Meyers, M. C., Van Woerkom, M., De Reuver, R. S. M., Bakk, Z., \& Oberski, D. L. (2015). Enhancing psychological capital and personal growth initiative: Working on strengths or deficiencies. Journal of Counseling Psychology, 62(1), 50-62. https://doi.org/10.1037/cou0000050

Moskowitz, J. T., Carrico, A. W., Duncan, L. G., Cohn, M. A., Cheung, E. O., Batchelder, A., ... Folkman, S. (2017). Randomized controlled trial of a positive affect intervention for people newly diagnosed with HIV. Journal of Consulting and Clinical Psychology, 85(5), 409-423. https://doi.org/10.1037/ccp0000188

Newman, A., Ucbasaran, D., Zhu, F., \& Hirst, G. (2014). Psychological capital: A review and synthesis. Journal of Organizational Behavior, 25, S120-S138. https://doi.org/10.1002/job.1916

Nielsen, K., Randall, R., \& Christensen, K. B. (2015). Do Different Training Conditions Facilitate Team Implementation? A Quasi-Experimental Mixed Methods Study. Journal of Mixed Methods Research. https://doi.org/10.1177/1558689815589050

O' Reilly, A. (2016). Developing Psychological Capital in a Student Population. Dublin Business School. 
Ortega-Maldonado, A., \& Salanova, M. (2017). Psychological capital and performance among undergraduate students: the role of meaning-focused coping and satisfaction. Teaching in Higher Education, $0(0)$, 1-13. https://doi.org/10.1080/13562517.2017.1391199

Peterson, S. J., Luthans, F., Avolio, B. J., Walumbwa, F. O., \& Zhang, Z. (2011). Psychological capital and employee performance: A latent growth modeling approach. Personnel Psychology, 64(2), 427-450. https://doi.org/10.1111/j.1744$6570.2011 .01215 . x$

Rego, A., Marques, C., Leal, S., Sousa, F., \& Pina e Cunha, M. (2010). Psychological capital and performance of Portuguese civil servants: Exploring neutralizers in the context of an appraisal system. International Journal of Human Resource Management, 21(9), 1531-1552. https://doi.org/10.1080/09585192.2010.488459

Reichard, R. J., Dollwet, M., \& Louw-Potgieter, J. (2014). Development of CrossCultural Psychological Capital and Its Relationship With Cultural Intelligence and Ethnocentrism. Journal of Leadership \& Organizational Studies, 21(2), 150-164. https://doi.org/10.1177/1548051813515517

Rew, L., Powell, T., Brown, A., Becker, H., \& Slesnick, N. (2017). An Intervention to Enhance Psychological Capital and Health Outcomes in Homeless Female Youths. Western Journal of Nursing Research, 39(3), 356-373. https://doi.org/10.1177/0193945916658861

Salanova, M., Llorens, S., Cifre, E., \& Martínez, I. M. (2012). We Need a Hero! Toward a Validation of the Healthy and Resilient Organization (HERO) Model. Group \& Organization Management, $37(6)$, 785-822. https://doi.org/10.1177/1059601112470405

Salanova, M., Llorens, S., \& Schaufeli, W. B. (2011). "Yes, I Can, I Feel Good, and I Just Do It!" On Gain Cycles and Spirals of Efficacy Beliefs, Affect, and 
Engagement. Applied Psychology, 60(2), 255-285. https://doi.org/10.1111/j.14640597.2010.00435.x

Seligman, M. E. P. (2011). Learned Optimism: How to Change Your Mind and Your Life. New York: Vintage. https://doi.org/10.1136/bmj.316.7134.870

Sheldon, K. M., \& Lyubomirsky, S. (2006). How to increase and sustain positive emotion: The effects of expressing gratitude and visualizing best possible selves. The Journal of Positive Psychology, 1(2), 73-82. https://doi.org/10.1080/17439760500510676

Sherlock-Storey, M., Moss, M., \& Timson, S. (2013). Brief coaching for resilience during organisational change-An exploratory study. The Coaching Psychologist, 9(1), 19-26.

Siu, O. L., Bakker, A. B., \& Jiang, X. (2014). Psychological Capital Among University Students: Relationships with Study Engagement and Intrinsic Motivation. Journal of Happiness Studies, 15(4), 979-994. https://doi.org/10.1007/s10902-013-9459-2

Snyder, C. R. (2000). Handbook of hope. San Diego: Academic Press.

Tkachenko, O., Hahn, H.-J., \& Peterson, S. L. (2017). Research-Practice Gap in Applied Fields: An Integrative Literature Review. Human Resource Development Review, 16(3), 235-262. https://doi.org/10.1177/1534484317707562

Torraco, R. J. (2016). Writing Integrative Literature Reviews. Human Resource Development Review, 15(4), 404-428. https://doi.org/10.1177/1534484316671606

Van Wingerden, J. (2016). Job Demands-Resources Interventions. Erasmus Universiteit Rotterdam. https://doi.org/10.13140/RG.2.1.1956.7603

Van Wingerden, J., Bakker, A. B., \& Derks, D. (2016). A test of a job demandsresources intervention. Journal of Managerial Psychology, 31(3), 686-701. https://doi.org/10.1108/JMP-03-2014-0086 
Van Wingerden, J., Derks, D., \& Bakker, A. B. (2017). The Impact of Personal Resources and Job Crafting Interventions on Work Engagement and Performance. Human Resource Management, 56(1), 51-67. https://doi.org/10.1002/hrm.21758

Williams, P., Kern, M. L., \& Waters, L. (2016). Exploring selective exposure and confirmation bias as processes underlying employee work happiness: An $\begin{array}{lllll}\text { intervention study. Frontiers in Psychology, } & 7(\mathrm{JUN}), \quad 878 .\end{array}$ https://doi.org/10.3389/fpsyg.2016.00878

Williams, P., Kern, M. L., \& Waters, L. (2017). The role and reprocessing of attitudes in fostering employee work happiness: An intervention study. Frontiers in Psychology, 8(JAN). https://doi.org/10.3389/fpsyg.2017.00028

Youssef, C. M., \& Luthans, F. (2007). Positive Organizational Behavior in the Workplace: The Impact of Hope, Optimism, and Resilience. Journal of Management, 33(5), 774-800. https://doi.org/10.1177/0149206307305562

Yuan, Q., Liu, S., Tang, S., \& Zhang, D. (2014). Happy@Work: protocol for a webbased randomized controlled trial to improve mental well-being among an Asian working population. BMC Public Health, 14(1), 685. https://doi.org/10.1186/14712458-14-685

Zhang, X., Li, Y.-L., Ma, S., Hu, J., \& Jiang, L. (2014). A Structured Reading MaterialsBased Intervention Program to Develop the Psychological Capital of Chinese Employees. Social Behavior and Personality: An International Journal, 42(3), 503515. https://doi.org/10.2224/sbp.2014.42.3.503

[i] Some articles did not report information about significant differences. 


\section{Chapter 3. Psychological capital and performance among undergraduate students: the role of meaning-focused coping and satisfaction}

This study explores the predictive relationships between psychological capital (PsyCap), meaning-focused coping, satisfaction and performance among undergraduate students. Six hundred and eighty two $(n=682)$ college students from 29 different academic programs completed an academic well-being survey, which included measures of PsyCap, coping strategies, and academic satisfaction (time 1). Performance data was collected five months later (time 2), at the end of the year. Path analysis results provided support for a sequential mediation model where PsyCap was directly related to performance, and indirectly related to performance through meaning-focus coping and satisfaction. In addition, PsyCap was directly associated with satisfaction, highlighting the importance of this psychological construct in academic settings. Understanding the role that meaning-focused coping and satisfaction play in the relationship between psychological capital and performance may be useful for scholars and lecturers to design optimal evidenced-based interventions to increase both wellbeing and academic achievement.

Keywords: psychological capital, meaning-focused coping, satisfaction, performance. $^{2}$

\footnotetext{
${ }^{2}$ Chapter 3 is based on: Ortega-Maldonado, A., \& Salanova, M. (2018). Psychological capital and performance among undergraduate students: the role of meaning-focused coping and satisfaction. Teaching in Higher Education, 23, 390-402. doi: 10.1080/13562517.2017.1391199
} 
Academic performance is one of the most relevant outcomes in the university setting. It refers to the knowledge that students have acquired at the end of a university program. Excellence in academic performance refers to high levels of theoretical, practical and technical knowledge. Academic performance and learning are proposed to influence individual's career success and employability (Fugate, Kinicki, \& Ashforth, 2004). For that reason, improving performance has become a central issue of the universities' political agenda. According to Siu, Bakker, and Jiang, (2014) university students need to meet current social and economy challenges and to find their competitive advantage. For that reason it is necessary to motivate students to obtain high levels in academic performance. Institutional programs are designed by universities to identify factors that influence higher performance on undergraduate studies. Deeper research on this field is necessary to develop evidence-based interventions to improve students' performance and learning (Lane, Hall, \& Lane, 2004). The present study aims to contribute to fill the gap in the academic performance literature, exploring the paths and relationships between academic performance and its psychological predictors.

\section{Psychological capital and performance}

A variable proposed to influence academic performance is psychological capital (PsyCap). PsyCap is a set of positive psychological resources that encompasses lower-order variables, i.e., self-efficacy, optimism, hope, and resilience (F. Luthans, Avolio, \& Youssef, 2007). PsyCap is defined as a state-like positive psychological construct that is highly involved in task performance and reaching goals. Undergraduate students use their psychological capital resources when completing a task or reaching an academic program goal. Under numerous challenging academic situations, students may need high level of self-efficacy to exert the necessary effort to complete the task. As well, optimism helps students to make positive attribution about 
succeeding. Finally, hope and resilience become important psychological resources to persevere towards achieving academic goals when problems and adversity appears.

Consequently, it is important to investigate whether PsyCap could enhance students' engagement and increase students' academic performance (Siu et al., 2014). PsyCap construct has been studied by scholars over the last decade, and there is vast empirical evidence linking it to performance and positive psychological outcomes in many different cultural contexts (see F. Luthans, Youssef-Morgan, \& Avolio, 2015). B. Luthans, K. Luthans, and Jensen, (2012) found a predictive relationship between PsyCap and performance among business students. PsyCap positively predicted psychological well-being (Nielsen, Newman, Smyth, Hirst, \& Heilemann, 2016) and students' satisfaction with life (Riolli, Savicki, \& Richards, 2012), and was related to future academic engagement (Siu et al., 2014), achievement and happiness (Datu, King, \& Valdez, 2016; Datu \& Valdez, 2015). Moreover, the research also shows the relationship between each of the different PsyCap components, performance and psychological positive outcomes. Lane, Hall, and Lane, (2004) found that self-efficacy predicted sport studies students' performance in a statistics module. Ouweneel, Le Blanc, \& Schaufeli, (2011) found that students' self-efficacy, hope, and optimism predicted future academic engagement. These recent findings allow us to formulate our first hypothesis:

Hypothesis 1: PsyCap at time 1 will be a predictor of performance over time (time 2).

\section{PsyCap in stress events: Meaning-focused coping}

PsyCap allows students to reach goals even when they have problems and are stressed. Stress is considered a psychophysiological response originated when people think that their personal resources are unsuitable for completing a particular task successfully (Lazarus \& Folkman, 1984). Undergraduate students face a number of 
stressors related to their academic coursework: uncomfortable classrooms, continuous evaluation and hard exams, high pressure to obtain a degree, long and intensive days of study, etc. (Riolli et al., 2012). They need high and adaptive levels of coping strategies in order to maintain psychological well-being and performance (Gram, Jæger, Liu, Qing, \& Wu, 2013; Meneghel, 2014). In this regard, according to Folkman (2008, 2010), people adopt two different coping strategies in a demanding situation: problem-focused coping to resolve the problem (when it is considered that something can be done) and emotion-focused coping to directly regulate distress (when nothing can be done and it is necessary to accept the failure). For example, being awake all night to study for an exam, might be a suitable coping strategy if not too much new information has to be learnt (problem focused). On the contrary, if you have never opened the book during the semester, it might be better to go to go to bed, recover and accept the possible failure in the exam (emotion focus). Both strategies would be oriented toward reducing distress, nonetheless, according to Folkman's proposal, there is a third useful option when efforts to manage a stressful event fail: meaning-focused coping. Following our example, accepting the failure could be the first step of starting to plan how to retake the class.

Meaning-focused coping may help students to reformulate the perceived demand and to appreciate it as a challenge rather than a threat. Students draw on their own beliefs, values, and existential goals to sustain coping and psychological wellbeing during difficult moments. This positive reframing generates positive emotions that help them to restore the psychological resources and motivation needed to persevere through their objectives (Folkman, 2008, 2009, 2010; Lazarus, 2006). PsyCap has been related to empower students to cope up with adverse events, buffering the negative stress outcomes and boosting the positive outcomes (Riolli et al., 2012). Riolli and colleges have suggested that the mechanism for this mediating relationship is that PsyCap may be related to more positive and less negative cognitive appraisals of 
stress. Addressing the call to investigate this relationship, we propose that meaningfocused coping may be the psychological mechanism that mediates between PsyCap and performance.

Hypothesis 2: Meaning-focused coping will mediate the relationship between PsyCap at time 1 and performance over time (time 2).

\section{Academic satisfaction: the role of positive emotions when adversities arise}

PsyCap and meaning-focused coping may shape a complementary cognitive and affective process related to achieving tasks and goals through positive emotions. Students may feel psychological well-being and satisfaction when they use their psychological capacities to complete their challenging tasks, especially if they are intrinsically motivated and they find real, personal meaning despite the difficulties. Bandura (2011) suggested that people make every effort to obtain satisfaction through their personal activities, especially if these activities bring meaning and purpose to their lives. It was proposed that meaning provides people with the ability to regulate emotions in daily activities (Tuazon, 2014). Furthermore, we understand that university studies play a central role in college students' lives, and we understand that university learning activities involves one's life journey during this period. Given these proposals, we hypothesize that academic satisfaction may be a mediator between "PsyCapmeaning-focused coping process" and academic performance.

Hypothesis 3: Academic satisfaction will mediate the relationship between meaning-focused coping at time 1 and performance over time (time 2).

To summarize, students use personal psychological resources to complete daily tasks and reach academic goals (Youssef-Morgan \& Luthans, 2015), persevering even 
under bad circumstances (Folkman, 2010). These personal resources are linked to excellence in academic performance, which might be influenced by cognitive-emotional evaluation processes such as academic satisfaction (Bandura, 2011). Identifying the path and relationships between academic performance and its psychological predictors could be used for developing evidence-based interventions to improve performance in university settings. The aim of the study was to assess the relationships between PsyCap, meaning-focused coping and satisfaction toward performance. The predictive path analysis model that tested the hypothesized relationships between PsyCap, meaning-focused coping, satisfaction and performance is depicted graphically in Figure 1. It was hypothesized that PsyCap would predict performance directly and also that PsyCap will predict meaning-focus coping which in turn predicts performance. Additionally, it was hypothesized that meaning-focused coping would predict satisfaction, and in turn satisfaction would predict performance as well.

Figure 1. Initial model hypothesized

TIME 1

TIME 2

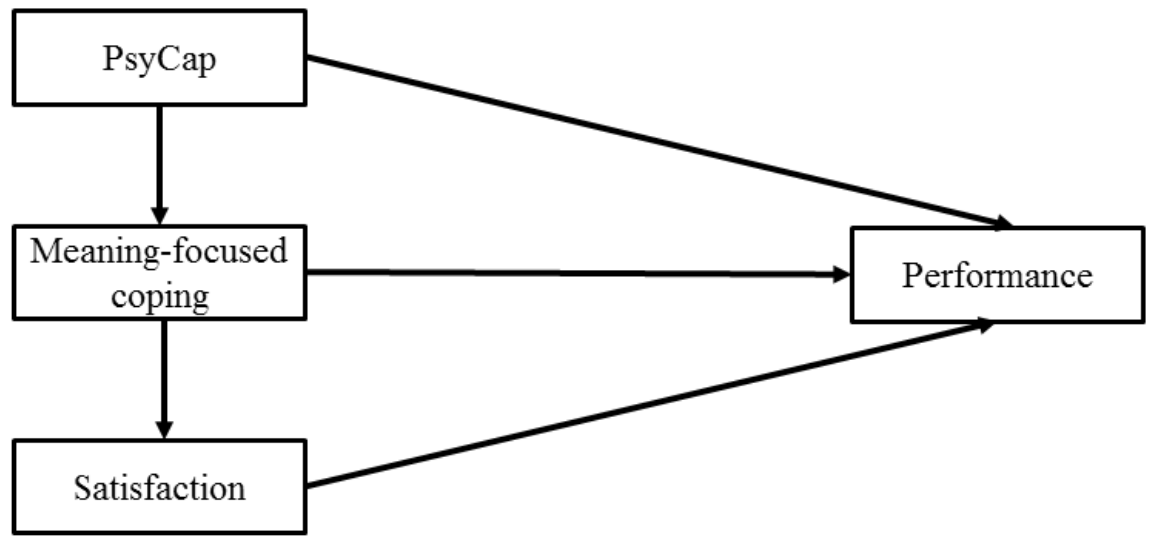




\section{Method}

\section{Sample and procedure}

The study was conducted at a Spanish University. Researchers gave a brief presentation of the study to participants during class time and invited them to participate on an academic well-being survey. Each student filled out a paper and pencil questionnaire. Sample comprised 682 students $(60.3 \%$ female). Participants were stratified and they belonged to the four colleges of which the University is composed: College of Humanities and Social Sciences (31.5\%), College of Law and Economics (25.1\%), School of Technology and Experimental Sciences (24\%), and College of Health Sciences (19.4\%). They belonged to 29 different undergraduate academic programs. Thereby $35.1 \%$ were studying at first year, $35.7 \%$ at second, $21.1 \%$ at third, $7 \%$ at fourth and finally $1 \%$ at fifth year. Ages ranged from 18 to 62 years old $\left(M_{\text {age }}=22.6\right.$ years; $\left.S D=5.6\right)$. Finally, $84.6 \%$ were not working at the time.

\section{Measures}

Psychological capital. To measure participants' PsyCap we adapted to the academic context the Spanish short version (12- item) of the Psychological Capital Questionnaire (PCQ-12) (Avey, Avolio, \& Luthans, 2011; F. Luthans, Avey, ClappSmith, \& Li, 2008). This questionnaire, distributed by Mind Garden, Inc., contains four items to measure hope, three items to measure self-efficacy, three items to measure resilience, and two to measure optimism. PsyCap is used as a higher order core construct in which these four positive psychological resources interact in a synergic way (see F. Luthans, Youssef-Morgan, \& Avolio, 2015). An example item is: "I can think of many ways to reach my current goals related to my studies". The reliability value is shown in Table 1. 
Meaning-focused coping strategies. Coping strategies were assessed using The Spanish version of the Brief COPE inventory adapted to the academic context (Morán, Landero, \& González, 2010; Perczek, Carver, Price, \& Pozo-Kaderman, 2000). This questionnaire contains 28 items to measure 14 different coping reactions, including both adaptive and maladaptive. According to coping strategies literature (Folkman, 2008; Folkman \& Moskowitz, 2000) and previous research findings in factor analysis of Brief COPE inventory among Spanish undergraduate students (Meneghel, 2014), meaning-focused coping was measured using acceptance, humour and positive reframing subscales. Example items are: "I've been learning to live with it" (acceptance subscale), "I've been making jokes about it" (humour subscale), and "I've been looking for the bright side of what is happening" (positive reframing subscale). The reliability value is shown in Table

Satisfaction. Satisfaction was measured with a four-item scale that took into consideration four main relevant aspects for university students: the university as a whole, the faculty to which they belonged, the program that they were studying at, and their professors. For each element students indicated the extent of their satisfaction on a 5-point Faces scale ranging from 1 (frowning) to 5 (smiling). An example item is: "How satisfied are you with the University?' The reliability value is shown in Table 1.

Performance. Performance was assessed by the Grade Point Average (GPA), provided by the University. It was obtained at the end of the school year around five months after the students completed the questionnaire. Consistent with the Spanish system of qualifications, GPA ranged from 5 (poor) to 10 (excellent). Because of the ethical rules of the University, at the end of the questionnaire, participants signed a consent form to obtain their permission to access to their GPA. 


\section{Data analysis}

We used path modelling (Figure 1) in order to test the hypotheses and estimate both direct and indirect effects (Preacher \& Hayes, 2008). Data were analysed using path analysis program IBM SPSS Amos 21. Standardized regression coefficients were used to examine predictive paths relationships that were hypothesized (Lane et al., 2004; Meneghel, 2014). The Normed Fit Index (NFI), the Incremental Fit Index (IFI), the Tucker-Lewis Index (TLI), the Comparative Fit Index (CFI) and the Root Mean Square Error of Approximation (RMSEA) were used to assess the fit of the hypothesised model. For RMSEA values of .05 are indicative of good fit and values up to .08 represent reasonable errors of approximation (Browne \& Cudeck, 1993). Whereas in the others indices, values of .95 or higher indicate good fit, being .90 acceptable (Hu \& Bentler, 1999).

Two strategies were conducted in order to mitigate problems with common method bias. First, predictor and criterion measures were obtained from different sources (Podsakoff, MacKenzie, \& Podsakoff, 2012). Thus, PsyCap, meaning-focused coping and satisfaction were obtained from self-report assessment (students), and performance was collected from an external source (GPA). Second, there was a time lag (five months) between obtaining GPA and the rest of measures.

\section{Results}

\section{Goodness of fit}

Descriptive statistics are presented in Table 1. All correlations were positive and in the expected direction. The initial hypothesized model (figure 1) showed a poor fit $(\mathrm{NFI}=.72, \mathrm{IFI}=.72, \mathrm{TLI}=-.71, \mathrm{CFI}=.71$ and $\mathrm{RMSEA}=.32$.$) . Given the correlations$ found between the study variables (see table 1) we decided to consult the modification indices in order to improve the model goodness of fit. Based on these indices and 
according to the literature (F. Luthans, Avolio, Avey, \& Norman, 2007; Riolli et al., 2012), we decided to include a direct path from PsyCap to satisfaction as well as removing a direct path from meaning-focused coping to academic performance (GPA). The final hypothesized model had a good fit $(\mathrm{NFI}=.99, \mathrm{IFI}=1, \mathrm{TLI}=.98, \mathrm{CFI}=1$, and RMSEA $=.04)$.

Table 1. Descriptive statistics for Psychological capital, meaning-focused coping, satisfaction and performance.

\begin{tabular}{lcccccc}
\hline & Mean & SD & 1 & 2 & 3 & 4 \\
\hline (1) Psychological Capital (T1) & 4.05 & 0.82 & $(.77)$ & & \\
(2) Meaning-focused coping (T1) & 1.73 & 0.56 & .39 & $(.68)$ & \\
(3) Satisfaction (T1) & 3.77 & 0.67 & .36 & .21 & $(.71)$ \\
(4) Performance (GPA) (T1) & 7.01 & 0.76 & .19 & .13 & .17 & -
\end{tabular}

Notes: $\mathrm{N}=682$. All correlations higher than .10 are significant at $p<.01$. Cronbach's $\alpha$ reliability estimates are listed in the diagonal in parentheses.

\section{Effects}

The final path model that tested hypothesized relationships between PsyCap, meaning-focused coping, satisfaction and performance is presented in Figure 2. Results showed significant relationships between PsyCap and meaning-focused coping. Meaning-focused coping significantly contributed to explain satisfaction and satisfaction significantly contributed to explain performance. PsyCap showed direct effects on performance and satisfaction.

Meaning-focused coping and satisfaction partially mediated the relationship between PsyCap and performance. We conducted bias corrected percentile method with 1000 bootstrap samples to calculate confidence intervals of indirect effects (Cheung \& Lau, 2007). We used the standardized indirect effect as an "index of mediation" (Preacher \& Hayes, 2008). The results of all the indirect effects found are presented in Table 2. Indirect effect of PsyCap on performance through meaning- 
focused coping and then satisfaction, was positive and significant (Indirect effect $=.041)$. Indirect effect of PsyCap on performance through satisfaction, was positive and significant (Indirect effect $=.037$ ). The total effect of PsyCap on performance was .191 and predictor variables explained a $5 \%$ of performance (GPA).

Table 2. Indirect effects.

\begin{tabular}{|c|c|c|c|c|}
\hline \multirow[t]{2}{*}{ Paths } & \multirow{2}{*}{$\begin{array}{c}\text { Indirect } \\
\text { effect }\end{array}$} & \multirow[t]{2}{*}{ SE } & \multicolumn{2}{|c|}{$95 \%$ Confidence Interval } \\
\hline & & & Lower Bound & $\begin{array}{l}\text { Upper } \\
\text { Bound }\end{array}$ \\
\hline PsyCap (T1) $\square$ Satisfaction (T1) & .031 & .040 & .002 & .065 \\
\hline PsyCap (T1) $\square$ Performance (T2) & .041 & .005 & .015 & .072 \\
\hline Meaning -focused coping (T1) $\square$ Performance (T2) & .009 & .029 & .001 & .025 \\
\hline
\end{tabular}

Notes: $\mathrm{N}=682$. Standardized path coefficients. ${ }^{* \star *} \mathrm{p}<.001$

Figure 2. Path model to investigate predictive relationships between PsyCap, Meaning-focused coping, satisfaction and performance among undergraduate students $(N=682)$.

TIME 1

TIME 2

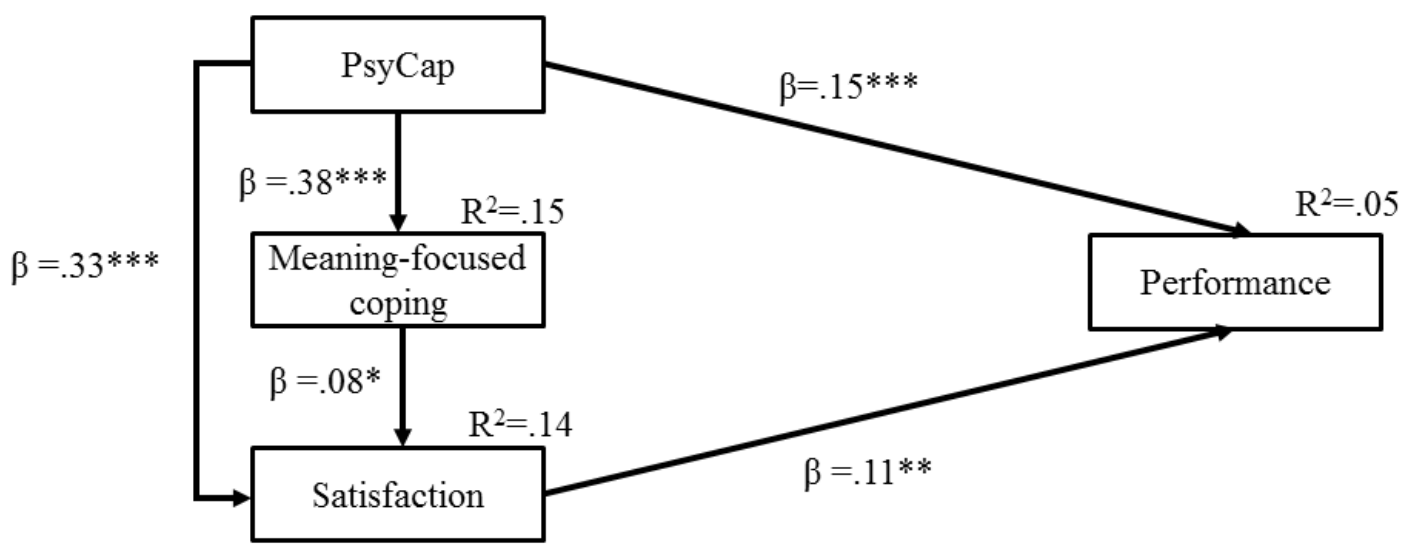

Notes: ${ }^{*} p<.05 ;{ }^{* *} p<.01 ;{ }^{* * *} p<.001$ 


\section{Discussion}

The aim of the study was to assess the predictive relationships between PsyCap, meaning-focused coping and satisfaction toward academic performance. The initial predictive path analysis model tested the hypothesis that PsyCap would predict performance directly, and also PsyCap would predict meaning-focused coping which in turn would predict performance. Additionally, it was hypothesized that meaning-focused coping would predict satisfaction, and satisfaction would predict performance as well. Results did not confirm this initial model, however, the alternative model proposed based on theoretical and statistical reasons, showed a good fit and statistically significant predictive paths. The final model confirmed most of the initial hypothesis formulated and showed interesting information regarding the role of academic satisfaction in academic performance.

These findings support our initial first hypothesis showing a positive direct relationship between PsyCap and performance over time. As in previous findings in undergraduate students' PsyCap, this study lends additional support to the capability of PsyCap as a predictor of positive psychological outcomes and excellence performance (Siu et al., 2014). Meaning-focused coping and satisfaction partially mediated the relationship between PsyCap and performance over time, supporting our third hypothesis. However, the final model did not confirm a direct effect of meaning-focused coping on performance, as it was suggested in our second hypothesis. These findings showed that meaning-focused coping strategies such acceptance, positive reappraisal, benefit finding and reminding, reordering priorities, self-regulation, and adaptive goal processes, (Folkman, 1997, 2008, 2009; Folkman \& Moskowitz, 2004) might reinforce students' PsyCap to persevere through reaching an academic goal. Students with higher levels in PsyCap would perceive the academic environment in a more positive way, assessing it as less distressing. They would perceive better challenging aspects of problems, and would be able to understand difficulties as possibilities to 
enhance learning and personal growth (Riolli et al., 2012). In line of Siu and colleges proposals (Siu et al., 2014), students with high development of PsyCap can cope better with the hindrance demands they face, which would influence positively in their success and performance.

Meaning-focused coping would help undergraduate students reaching the challenges of their study, connecting with their personal values and intrinsic motivation. Satisfaction, such a positive emotional outcome, could play a full mediating role between meaning-focused coping and academic performance. This mediation role could be an explanation of how reformulating a perceived demand to understand it as a challenge rather than a threat, may predict better performance. In this regard, this positive reframing would generate positive emotions, that might help students to restore coping resources to face demands (Folkman, 2008, 2009; Lazarus, 2006). That is, students need to be satisfied with their academic lives in order to look for the bright side in adverse situations.

The final model showed a non-hypothesised path relationship: PsyCap was directly associated with satisfaction, highlighting the importance of this variable in academic settings. PsyCap is a positive state-like based on psychological resources and involved in completing tasks successfully. For this reason, a high level of PsyCap means higher levels of happiness, satisfaction and psychological well-being (Datu et al., 2016; Datu \& Valdez, 2015; Nielsen et al., 2016; Riolli et al., 2012; Siu et al., 2014). Students feel good when they use their personal strengths and resources to complete tasks to reach academic goals. Besides, being satisfied with their studies could also reinforce the power of their psychological resources, improving excellence in their performance. Moreover, there is recent empirical evidence about how positive psychological resources increase academic satisfaction and well-being, supporting the evidence of the relevance of positive predictors on positive outcomes. Howells, Stafford, Guijt, and Breadmore (2017) found that gratitude between doctoral students 
and their supervisors have positive effects on students' psychological well-being, motivation and self-efficacy. Hanson, Trolian, Paulsen, and Pascarella (2016) found that social cooperation and collaborative learning had a significant positive effect on student's psychological well-being.

\section{Practical implications}

This study suggests multivariable predictors and mechanisms to explain and understand academic performance. Results show specifically a sequential mediated relationship between PsyCap and performance, revealing the mediating role of meaning-focused coping and satisfaction in this relationship. These theoretical links between PsyCap, meaning-focused coping, satisfaction and performance, along with the results of the present study, indicate the relevance of considering meaning-focused coping and PsyCap as two complementary psychological resources that can improve students' fulfilment.

These results provide lectures with empirical evidence to develop and implement innovative pedagogical strategies to enhance students' quality of learning and excellence performance. In order to optimize these interventions these strategies must be based on theory and research (Lane et al., 2004). The results of this study support the PsyCap literature on evidence-based interventions and institutional programs oriented to improve psychological well-being and performance in university settings (Avey, Luthans, Smith, \& Palmer, 2010; F. Luthans, Avey, Avolio, \& Peterson, 2010). However, these results suggest that adding meaning-focused coping content to PsyCap workshops (F. Luthans, Avey, Avolio, Norman, \& Combs, 2006) could be a useful strategy to reinforce the effectiveness of this positive intervention. Thus, students could attend face-to-face, small-group workshop sessions, composed of specific exercises designed to develop hope, optimism, self-efficacy, and resilience (PsyCap) (F. Luthans et al., 2006), and they could also train different meaning-focused 
coping skills. Developing personal capacity of acceptance, positive reappraisal, benefit finding, and reordering priorities and goal processes could be essential to increase levels of academic performance and psychological well-being. Positive education and positive psychology basis and literature may serve as a proper scaffolding to build these interventions, not only for extra curricula workshops but also for designing program pedagogical strategies.

\section{Limitations}

This study has several limitations which highlight important avenues for future research. First, we use self-reported data for psychological measures, which increases the risk of common method bias (Podsakoff, MacKenzie, Lee, \& Podsakoff, 2003). We consider that the use of self-reports could be justified by the nature of the constructs. However, we conducted two strategies in order to mitigate these problems with common method bias. First, predictor and criterion measures were obtained from different sources (Podsakoff et al., 2012). Thus, PsyCap, meaning-focused coping and satisfaction were obtained from self-report assessment (students), and performance was collected from an external source (GPA). On the other hand, there was a time lag (five months) between obtaining GPA and the rest of measures.

Second, our results are based on a sample from the same university. However, we found interesting results to enhance PsyCap and performance literature among students that came from different faculties and several university programs. Thus, we consider that the results need to be replicated in others universities and countries, to allow their generalizability.

Additionally, our model explains only $5 \%$ of students' performance. It would be interesting to reach higher levels of statistical explanation. However, academic performance is a construct influenced by several social, economic, psychological and pedagogical variables. It takes place in a complex multivariate social context, as it is 
education setting. Factors such as availability of resources, expectances, motivation, or previous experience, has been proposed as predictors of success in higher education (Hernández-Sánchez \& Ortega-Maldonado, 2015). Thus, previous findings in undergraduate students' PsyCap (B. Luthans et al., 2012) explained similar percentage of the variance of GPA (7\%). Additionally, previous findings in undergraduate students' coping (MacCann, Lipnevich, Burrus, \& Roberts, 2012) explained similar percentage of the variance of GPA ( $2 \%$, without considering the effects of personality factors). Finally, we consider that explaining more than $5 \%$ of students' performance is a difficult and important challenge for scholars.

\section{Conclusions and prospective}

According to our findings, PsyCap, meaning-focused coping and satisfaction have a predictor role on academic performance. Additional directions for future research include testing personal differences and factors to distinguish meaningfocused coping effectiveness with academic stress (MacCann et al., 2012; Riolli et al., 2012). Recent research has shown links between the student personality and meaning-focused coping strategies of college students. Gustems-Carnicer and Calderón (2016) found that positive reappraisal is predicted by the wisdom virtue which include personal strengths such as creativity, curiosity, perspective, judgement and love of learning (Peterson \& Seligman, 2004). Prosen and Vitulić (2016) found differences in the frequency of use of the cognitive reappraisal (meaning and positive) in different attachment styles in students. In this regard, qualitative research could be a useful methodology to obtain deeper information to evaluate student personality and coping mechanisms.

Finally, it would be important that additional directions for future research also include designing and testing interventions on PsyCap and meaning-focused coping at the academic setting. Students need excellence performance in order to get better 
employability. They need to learn technical knowledge and develop better learning strategies. But they also need to increase their psychological capacities and skills related to face daily life with emotional intelligence. Higher education institutions should address this real need, and scholars and lecturers could support them with evidencebased interventions. The better the interventions are, the better the students' quality of life will be.

\section{References}

Avey, J. B., Avolio, B. J., \& Luthans, F. (2011). Experimentally analyzing the impact of leader positivity on follower positivity and performance. Leadership Quarterly, 22(2), 282-294. http://doi.org/10.1016/j.leaqua.2011.02.004

Avey, J. B., Luthans, F., Smith, R. M., \& Palmer, N. F. (2010). Impact of positive psychological capital on employee well-being over time. Journal of Occupational Health Psychology, 15(1), 17-28. http://doi.org/10.1037/a0016998

Bandura, A. (2011). A Social Cognitive perspective on Positive Psychology. Revista de Psicología Social, 26(1), 7-20. http://doi.org/10.1174/021347411794078444

Browne, M. W., \& Cudeck, R. (1993). Alternative ways of assessing model fit. In K. A. Bollen \& J. S. Long (Eds.), Testing structural equations models (pp. 136-162). Newbury Park, CA: Sage.

Cheung, G. W., \& Lau, R. S. (2007). Testing Mediation and Suppression Effects of Latent Variables. Organizational Research Methods, 11(2), 296-325. JOUR. http://doi.org/10.1177/1094428107300343

Datu, J. A. D., King, R. B., \& Valdez, J. P. M. (2016). Psychological capital bolsters motivation, engagement, and achievement: Cross-sectional and longitudinal studies. The Journal of Positive Psychology, 1-11. http://doi.org/10.1080/17439760.2016.1257056 
Datu, J. A. D., \& Valdez, J. P. M. (2015). Psychological Capital Predicts Academic Engagement and Well-Being in Filipino High School Students. The Asia-Pacific Education Researcher, (2001). http://doi.org/10.1007/s40299-015-0254-1

Folkman, S. (1997). Positive psychological states and coping with severe stress. Social Science and Medicine, 45(8), 1207-1221. http://doi.org/10.1016/S02779536(97)00040-3

Folkman, S. (2008). The case for positive emotions in the stress process. Anxiety, Stress, and Coping, 21(1), 3-14. http://doi.org/10.1080/10615800701740457

Folkman, S. (2009). Commentary on the Special Section "Theory-Based Approaches to Stress and Coping." European Psychologist, 14(1), 72-77. http://doi.org/10.1027/1016-9040.14.1.72

Folkman, S. (2010). Stress, coping, and hope. Psycho-Oncology, 19(9), 901-8. http://doi.org/10.1002/pon.1836

Folkman, S., \& Moskowitz, J. T. (2000). Positive affect and the other side of coping. American Psychologist, 55(6), 647-654. http://doi.org/10.1037//0003066X.55.6.647

Folkman, S., \& Moskowitz, J. T. (2004). Coping: pitfalls and promise. Annual Review of Psychology, 55, 745-74. http://doi.org/10.1146/annurev.psych.55.090902.141456

Fugate, M., Kinicki, A. J., \& Ashforth, B. E. (2004). Employability: A psycho-social construct, its dimensions, and applications. Journal of Vocational Behavior, 65(1), 14-38. http://doi.org/10.1016/j.jvb.2003.10.005

Gram, M., Jæger, K., Liu, J., Qing, L., \& Wu, X. (2013). Chinese students making sense of problem-based learning and Western teaching - pitfalls and coping strategies. Teaching in Higher Education, 18(7), 761-772. JOUR. http://doi.org/10.1080/13562517.2013.836096 
Gustems-Carnicer, J., \& Calderón, C. (2016). Virtues and character strengths related to approach coping strategies of college students. Social Psychology of Education, 19(1), 77-95. http://doi.org/10.1007/s11218-015-9305-y

Hanson, J. M., Trolian, T. L., Paulsen, M. B., \& Pascarella, E. T. (2016). Evaluating the influence of peer learning on psychological well-being. Teaching in Higher Education, 21(2), 191-206. http://doi.org/10.1080/13562517.2015.1136274

Hernández-Sánchez, A. M., \& Ortega-Maldonado, A. (2015). Hacia la personalización del e-Learning: La afectividad y su repercusión en el bienestar subjetivo. Revista Lasallista de Investigacion, 12(2), 194-203.

Howells, K., Stafford, K., Guijt, R., \& Breadmore, M. (2017). The role of gratitude in enhancing the relationship between doctoral research students and their supervisors. Teaching in Higher Education, 1-18. JOUR. http://doi.org/10.1080/13562517.2016.1273212

Hu, L., \& Bentler, P. M. (1999). Cutoff criteria for fit indexes in covariance structure analysis: Conventional criteria versus new alternatives. Structural Equation Modeling: A Multidisciplinary Journal, 6(1), 1-55. JOUR. http://doi.org/10.1080/10705519909540118

Lane, A. M., Hall, R., \& Lane, J. (2004). Self-efficacy and statistics performance among Sport Studies students. Teaching in Higher Education, 9(4), 435-448. http://doi.org/10.1080/1356251042000252372

Lazarus, R. S. (2006). Emotions and interpersonal relationships: toward a personcentered conceptualization of emotions and coping. Journal of Personality, 74(1), 9-46. http://doi.org/10.1111/j.1467-6494.2005.00368.x

Lazarus, R. S., \& Folkman, S. (1984). Stress, Appraisal, and Coping. New York: Springer. 
Luthans, B. C., Luthans, K. W., \& Jensen, S. M. (2012). The Impact of Business School Students' Psychological Capital on Academic Performance. Journal of Education for Business, $\quad$ 87(October), 253-259. http://doi.org/10.1080/08832323.2011.609844

Luthans, F., Avey, J. B., Avolio, B. J., Norman, S. M., \& Combs, G. M. (2006). Psychological capital development: toward a micro-intervention. Journal of Organizational Behavior, 27, 387-393.

Luthans, F., Avey, J. B., Avolio, B. J., \& Peterson, S. J. (2010). The Development and Resulting Performance Impact of Positive Psychological Capital. Human Resource Development Quarterly, 21(1), 41-67. http://doi.org/10.1002/hrdq

Luthans, F., Avey, J. B., Clapp-Smith, R., \& Li, W. (2008). More evidence on the value of Chinese workers' psychological capital: A potentially unlimited competitive resource? The International Journal of Human Resource Management, 19(5), 818-827. http://doi.org/10.1080/09585190801991194

Luthans, F., Avolio, B. J., Avey, J. B., \& Norman, S. M. (2007). Positive Psychological Capital: Measurement and Relationship with Performance and Satisfaction. Personnel Psychology, 60, 541-572.

Luthans, F., Avolio, B. J., \& Youssef, C. M. (2007). Psychological Capital: Developing the Human Competitive Edge. Oxford University Press.

Luthans, F., Youssef-Morgan, C. M., \& Avolio, B. J. (2015). Psychological Capital and Beyond. New York: Oxford University Press.

MacCann, C., Lipnevich, A. a., Burrus, J., \& Roberts, R. D. (2012). The best years of our lives? Coping with stress predicts school grades, life satisfaction, and feelings about high school. Learning and Individual Differences, 22(2), 235-241. http://doi.org/10.1016/j.lindif.2011.08.004 
Meneghel, I. (2014). An Integrated Analysis of Resilience: How to Achieve Positive Outgrowths. Universitat Jaume I de Castellón.

Morán, C., Landero, R., \& González, M. T. (2010). COPE-28: A Psychometric Analysis of the Spanish Version of the Brief COPE. Universitas Psychologica, 9(2), 543552.

Nielsen, I., Newman, A., Smyth, R., Hirst, G., \& Heilemann, B. (2016). The influence of instructor support, family support and psychological capital on the well-being of postgraduate students: a moderated mediation model. Studies in Higher Education, Advance on(February). http://doi.org/10.1080/03075079.2015.1135116

Ouweneel, E., Le Blanc, P. M., \& Schaufeli, W. B. (2011). Flourishing students: A longitudinal study on positive emotions, personal resources, and study engagement. The Journal of Positive Psychology, 6(2), 142-153. http://doi.org/10.1080/17439760.2011.558847

Perczek, R., Carver, C. S., Price, A. A., \& Pozo-Kaderman, C. (2000). Coping, Mood, and Aspects of Personality in Spanish Translation and Evidence of Convergence With English Versions. Journal of Personality Assessment, 74(1), 63-87.

Peterson, C., \& Seligman, M. E. P. (2004). Character Strengths and Virtues. Oxord University Press. http://doi.org/313971759

Podsakoff, P. M., MacKenzie, S. B., Lee, J.-Y., \& Podsakoff, N. P. (2003). Common method biases in behavioral research: A critical review of the literature and recommended remedies. Journal of Applied Psychology. JOUR PMID 14516251, Podsakoff, Philip M.: Department of Management, Kelley School of Business, Indiana University, 1309 East Tenth Street, Bloomington, IN, US, 47405-1701, podsakof@indiana.edu: American Psychological Association. http://doi.org/10.1037/0021-9010.88.5.879 
Podsakoff, P. M., MacKenzie, S. B., \& Podsakoff, N. P. (2012). Sources of Method Bias in Social Science Research and Recommendations on How to Control It. Annual Review of Psychology, 63, 539-569. http://doi.org/10.1146/annurev-psych120710-100452

Preacher, K. J., \& Hayes, A. F. (2008). Asymptotic and resampling strategies for assessing and comparing indirect effects in multiple mediator models. Behavior Research Methods, 40(3), 879-891. article. http://doi.org/10.3758/BRM.40.3.879

Prosen, S., \& Vitulić, H. S. (2016). Emotion Regulation and Coping Strategies in Pedagogical Students with Different Attachment Styles. Japanese Psychological Research, 58(4), 355-366. http://doi.org/10.1111/jpr.12130

Riolli, L., Savicki, V., \& Richards, J. (2012). Psychological Capital as a Buffer to $\begin{array}{lll}\text { Student } \quad \text { Stress. } & \text { Psychology, } & \text { 3(12), }\end{array}$ http://doi.org/10.4236/psych.2012.312A178

Siu, O. L., Bakker, A. B., \& Jiang, X. (2014). Psychological Capital Among University Students: Relationships with Study Engagement and Intrinsic Motivation. Journal of Happiness Studies, 15(4), 979-994. http://doi.org/10.1007/s10902-013-9459-2

Tuazon, G. . F. M. (2014). Applying Meaning at Work: Effective Use of Meaning in the Workplace. International Journal of Existential Psychology and Psychotherapy, 5, $157-169$.

Youssef-Morgan, C. M., \& Luthans, F. (2015). Psychological Capital and Well-being. Stress and Health, 31(3), 180-188. http://doi.org/10.1002/smi.2623 


\section{Chapter 4. A Positive Intervention to Develop Psychological \\ Capital and Well-being: the role of Meaning-focused Coping and Daily Practice}

This study explores the effects of a combination of positive resources and daily practice after a workshop on an evidence-based, psychological capital (PsyCap) intervention. Based on the relationship between meaning-focused coping and PsyCap, we extend current research on PsyCap interventions by using a quasi-experimental pre-test, post-test, and follow-up control-group design. In addition, we test positive outcomes of the PsyCap intervention in terms of effects on participants' psychological well-being. A sample of 56 university students was randomly allocated to three different intervention groups and to a control group. They filled out questionnaires five days before and after the intervention, and one month after the second measurement. The results of multivariate analysis of variance (MANOVA) show that training in meaningfocused coping with daily practice after the workshop has a significant impact on participants' PsyCap and psychological well-being, at Time 2 and Time 3. A practical implication of the outcomes of this study is that the combination of positive resources and daily practice after the workshop are useful intervention strategies to maintain positive effects on personal resources and the development of well-being over time.

Keywords: Psychological Capital; Coping strategies; Positive organizational behaviour; Well-being; Training.

\footnotetext{
${ }^{3}$ Chapter 4 has been submitted for publication as: Ortega-Maldonado, A., \& Salanova, M. A Positive Intervention to Develop Psychological Capital and Well-being: the role of Meaning-focused Coping and Daily Practice. Journal of Leadership and Organizational Studies.
} 
People spend a lot of their lives in educational and work settings, and they have an internal potential to develop positive competences and psychological resources in these contexts. These personal resources and strengths refer to individuals' positive capabilities oriented toward achieving tasks and goals. They complement knowledge, talent, and skills, and they can be measured, developed, and effectively managed in order to improve positive outcomes (F. Luthans, Avolio, \& Youssef, 2007). A wellestablished set of positive psychological resources consists of self-efficacy, hope, optimism, and resilience, which have been conceptually defined by Luthans and colleagues as psychological capital (PsyCap) (F. Luthans, Avolio, \& Youssef, 2007; F. Luthans, Youssef-Morgan, \& Avolio, 2015). The PsyCap construct has been studied by scholars since the beginning of the past decade, and there is ample empirical evidence linking it to positive outcomes such as performance, engagement, and well-being in both educational and work contexts (Rabenu, Yaniv, \& Elizur, 2016; Siu, Bakker, \& Jiang, 2014; Youssef-Morgan \& Luthans, 2015).

When people complete a task or reach a goal, they use, in one way or another, their psychological capital resources. However, according to The Cognitive Theory of Stress and Coping (Lazarus \& Folkman, 1984; Lazarus, 1966), sometimes completing a task or reaching a goal can also be demanding and stressful, especially when people consider their personal resources to be unsuitable for completing a task successfully. The coping process is aimed to regulate distress, and it plays an important role in achievement, health and well-being (Folkman, 2009; Lazarus \& Folkman, 1984). The coping process is not exclusively related to decreasing the effects of negative emotions because it is also associated with the generation of positive emotions. Some authors have proposed that positive emotions help to manage stress events in a healthier and more efficient way, and that they are useful in restoring the positive resources needed to obtain a favourable outcome (Folkman, 2008). Strategies such as benefit finding, stress-related growth, and self-regulation goals are included in 
this type of coping process, referred to as meaning-focused coping (Folkman \& Moskowitz, 2004; Folkman, 1997).

In response to the call by F. Luthans et al. (2015) to explore a wide range of positive psychological capacities that make up PsyCap, and according to previous research findings about PsyCap and coping (Rabenu, Yaniv, \& Elizur, 2016), we propose that meaning-focused coping could be linked to PsyCap in terms of their theoretical foundations and potential applicability in educational and work contexts. For example, when people try to see the bright side of a problem and reorder their priorities after suffering a setback, they are being more persistent and redirecting the paths to their goals, using hope as a personal resource. Moreover, stress-related growth and resilience are linked to persisting and bouncing back from adversity. Consequently, PsyCap and meaning-focused coping may shape a complementary cognitive and affective process related to achieving tasks and goals through positive affect.

PsyCap is characterized by openness to change and development. For this reason, Luthans and colleagues (2006) designed a highly focused and very short training workshop called Psychological Capital Intervention (PCI). This microintervention has an optimal design in educational and work environments because it meets the need to maximize results in a short time frame. Namely, it is a suitable tool for participants who are interested in increasing their personal resources but do not have much time to invest in interventions, or do not have the option of participating in a longer training program. Moreover, in order to facilitate its application by Human Resources practitioners, PCI includes three special characteristics: 1) short duration; 2) a link between workshop activities and participants' goals; and 3) suitability for different cultures and settings. However, it is necessary to have empirical evidence about its effectiveness and generalize its effects to different contexts and conditions, and this study tries to achieve this goal. 
A few studies have examined PCl's capacity to increase PsyCap in educational and work settings (Dello Russo \& Stoykova, 2015; B. Luthans, K. Luthans, \& Avey, 2014; F. Luthans et al., 2006; F. Luthans, Avey, Avolio, \& Peterson, 2010; F. Luthans, Avey, \& Patera, 2008). However, to the best of our knowledge, further research is needed on the reliability, effectiveness, and generalization of $\mathrm{PCl}$, taking into account different trainers and contexts from those of the original studies conducted by the authors (Dello Russo \& Stoykova, 2015), and reinforcing training by adding contents that share theoretical foundations with this construct (F. Luthans et al., 2015).

PsyCap development in the $\mathrm{PCl}$ model is based on analysing personal resources and designing the best way to reach a goal in a specific moment. $\mathrm{PCl}$ training also leads participants to be proactive when some problems arise. People learn to take into account future problems and possible solutions via coping strategies such as benefit finding, stress related growth, and self-regulation goals. In this regard, the links between PsyCap and coping (i.e., meaning-focused coping) could reinforce $\mathrm{PCl}$ by adding meaning-focused coping contents to the interventions. Through this positive resource combination strategy, we address Dello Russo and Stoykova's (2015) suggestion to conduct theory-driven replication and extension studies that offer the opportunity to reinforce $\mathrm{PCl}$.

Moreover, durability and the transfer to everyday activity are essential elements in increasing the applicability and usefulness of a micro-intervention in educational and work contexts. Based on Dello Russo and Stoykova's (2015) call to explore PCl's longer term effects, we examine the extent to which knowledge and skills acquired during the micro-intervention and daily practice for three weeks positively affect the durability of PsyCap development. It has been suggested that frequent positive practice is associated with positive personal development over time (Lyubomirsky \& Layous, 2013). Thus, we propose that daily practice with meaning- 
focused coping strategies could be a tool to keep the training active and reinforce the efficacy of the PsyCap micro-intervention and its durability over time.

We extend current research on psychological capital development, and recent research on the relationship between PsyCap, coping, well-being, and performance (Rabenu, Yaniv, \& Elizur, 2016). To the best of our knowledge, no single study has directly examined the effects of psychological capital intervention on positive outcomes in terms of health and psychological well-being. An integrative definition of psychological well-being is the experience of stable, global and deep sense of wellbeing. This experience includes life satisfaction, positive affectivity (hedonia), fulfilment and purpose (eudaimonia), and quality of interpersonal relationships (see Hervás \& Vázquez, 2013). Positive interventions in educational and work contexts aim to improve individual performance and satisfaction, with the ultimate goal of promoting health, quality of work life, and excellence (Salanova, Llorens, \& Rodríguez, 2010). This study was designed to contribute to the psychological capital research literature by testing the development of psychological well-being after PsyCap intervention.

In summary, we examine the effects and mechanisms of three groups with combinations of psychological capital intervention: PsyCap (micro)Intervention (PCI), PsyCap with meaning-focused COPing (micro)Intervention (COPI), and PsyCap with meaning-focused coping (micro)Intervention plus three weeks of DAilY practice (DAYI). We compare the effects of these three conditions to a control group (CONTROL).

\section{Developing PsyCap: A micro-intervention}

PsyCap is defined and conceptualized as a positive higher-order construct that encompasses lower-order variables, namely self-efficacy, optimism, hope, and resilience (F. Luthans, Avolio, \& Youssef, 2007). Thus, a comprehensive definition of PsyCap is "an individual's positive psychological state of development that is characterized by: (1) having confidence (self-efficacy) to take on and put in the 
necessary effort to succeed at challenging tasks; (2) making a positive attribution (optimism) about succeeding now and in the future; (3) persevering toward goals and, when necessary, redirecting paths to goals (hope) in order to succeed; and (4) when beset by problems and adversity, sustaining and bouncing back and even beyond (resilience) to attain success. (p. 3)".

PsyCap is a positive individual state that has been associated with increased levels of health, motivation, commitment, and performance, showing its potentially widespread importance (Cameron, 2013). Evidence shows a relationship between PsyCap and well-being. For instance, PsyCap has been negatively related to stress and positively related to well-being in leaders and entrepreneurs (Baron, Franklin, \& Hmieleski, 2013; Roche, Haar, \& Luthans, 2014). PsyCap has been positively related to employees' eudaimonic and hedonic well-being over time (Avey, Luthans, Smith, \& Palmer, 2010; Culbertson, Fullagar, \& Mills, 2010).

Moreover, research also shows this relationship in samples of preprofessionals in many different cultural contexts. Riolli, Savicki, and Richards (2012), in an undergraduate student sample from North America, found that PsyCap mediated between stress and psychological and physical well-being, and it increased students' satisfaction with life. Ouweneel, Le Blanc, and Schaufeli (2011) found that students' personal resources of self-efficacy, hope, and optimism predicted future academic engagement. Finally, PsyCap positively predicted academic engagement and academic happiness (Datu \& Valdez, 2015; Siu et al., 2014).

Luthans and colleagues designed $\mathrm{PCl}$, a very short training procedure (from one to three hours) to develop individuals' PsyCap (F. Luthans et al., 2006; F. Luthans, Avolio, Avey, \& Norman, 2007). The PCl model is based on previous intervention research to develop each of the four PsyCap components. Therefore, face-to-face, small-group workshop sessions are composed of specific exercises designed to 
develop hope, optimism, self-efficacy, and resilience. Hope is developed through training in goal-setting, designing and implementing obstacles, and planning alternative pathways to attain goals (Snyder, 2000). Optimism is developed through building efficacy and confidence and increasing positive expectancy and attributions (Seligman, 1998). Self-efficacy is developed, through active mastery experience with goal-setting and the visualization of reaching the goal successfully and, on the other hand, through modelling, vicarious learning, and social persuasion, by interacting with other participants in the workshop and the facilitator (Bandura, 1997). Resilience is developed by activating cognitive, emotional, and behavioural processes in order to modify participants' perceptions of self-influence on external conditions (Masten, 2001).

$\mathrm{PCl}$ has been tested in several studies. Results show that PCl significantly increased participants' levels of PsyCap in experimental groups compared to control groups in studies with students, managers, and workers (B. Luthans et al., 2014; F. Luthans et al., 2006, 2010; F. Luthans, Avey, \& Patera, 2008). Regarding PCl and positive effects on participants' psychological well-being and performance, Fred Luthans et al. (2010), for the first time, found empirical evidence showing participants' improved performance. However, there is a gap in the empirical evidence about whether PsyCap development has a significant positive impact on participants' health and psychological well-being outcomes. In order to replicate these results, and based on the relationship between PsyCap and psychological well-being found in previous research, in this study we formulate the following hypothesis:

Hypothesis 1: Psychological capital (1a) and psychological well-being (1b) increase significantly after PCI intervention (T2), compared to their levels prior to the intervention (T1) and compared to a control group. 


\section{Meaning-focused Coping: A Related Personal Resource}

PsyCap is a positive cognitive psychological state related to success on challenges, goals, and tasks. According to the literature, an important cognitive and affective process takes place when we try to reach goals or complete tasks successfully: the stress and coping process (Moos, 2002). Lazarus and Folkman (1984) proposed The Cognitive Theory of Stress and Coping, an appraisal-based model that defines coping as "constantly changing cognitive and behavioural efforts to manage specific external and/or internal demands that are appraised as taxing or exceeding the resources of the person" (p. 141).

According to Lazarus and Folkman's initial stress and coping model (Lazarus \& Folkman, 1984; Lazarus, 1966), the individual adopts two different kinds of coping strategies when facing a demanding situation: problem-focused coping to resolve the event (suitable for situations where something can be done) and emotion-focused coping to regulate distress directly (suitable for situations that have to be accepted). For example, asking for help from a partner to meet a tight deadline might be a suitable coping strategy if you have a good social network. However, if you do not, you might be better off seeking emotional support from your family because you will not finish the task on time.

Both strategies would be oriented toward reducing distress, but they do not always succeed. In this regard, negative and positive emotions have been found to cooccur when people face stressful events (Folkman \& Moskowitz, 2000; Folkman, 2008). Thus, the stress and coping model has been reformulated, proposing that if efforts to manage a stressful event fail, positive emotions provide relief from distress and restore the psychological resources and motivation needed to sustain the coping process. This new category of strategies is known as meaning-focused coping, where 
the individual draws on his/her own beliefs, values, and existential goals to sustain coping and well-being during a difficult moment (Folkman, 2008, 2010).

As occurs with PsyCap resources, people's use of coping strategies depends not only on their personal characteristics (i.e., dispositions, beliefs and goals), but also on the specific stressful events, such as contextual characteristics of the situation or their psychological states at the moment (Folkman \& Moskowitz, 2000; Lazarus \& Folkman, 1984). Thus, meaning-focused coping helps people to reformulate the perceived demand, appreciating it as a challenge (rather than a threat). This positive reframing generates positive emotions that help people to restore coping resources to face demands (Folkman, 2008, 2009; Lazarus, 2006). Research based on quantitative and qualitative data has distinguished several resources as examples of meaningfocused coping, including acceptance, positive reappraisal, benefit finding and reminding, reordering priorities, self-regulation, adaptive goal processes, and stress related growth (Folkman \& Moskowitz, 2004; Folkman, 1997, 2008, 2009).

Based on this empirical evidence, some similarities are found between PsyCap resources (and approaches to its development through $\mathrm{PCl}$ ) and meaningfocused coping strategies. PsyCap development in the PCI model is based mainly on analysing personal resources and designing the best way to reach a goal at a specific point in time. In this regard, participants need to use different strategies to positively examine themselves and the event and, based on this appraisal, design an efficient pathway to reach a goal, proactively taking future problems and possible solutions into account. Additionally, training in meaning-focused coping strategies might be related to the PCI model conceptually and operationally. Both interventions shares strategies for enhancing assets, avoiding risks, and focusing on processes in order to influence the interpretation of adverse events. Moreover, recent empirical research found that coping strategies such as acceptance, positive reframing, or adaptation, mediated the 
relationship between PsyCap and positive outcomes of well-being and performance (Rabenu, Yaniv and Elizur, 2016).

We propose that PsyCap may be reinforced by meaning-focused coping strategies during difficult moments. Thus, when problems arise, meaning-focused coping may be a complementary cognitive process related to achieving tasks and goals through positive affect. For this reason, the present study aims to improve PCl's effectiveness through a positive resources combination strategy. A very short training session in meaning-focused coping will extend to the development of self-efficacy, hope, optimism, and resilience (COPI). We formulate the following hypothesis:

Hypothesis 2: Psychological Capital (2a) and psychological well-being (2b) increase significantly after a COPI intervention (T2), compared to their level prior to the intervention (T1) and compared to the $\mathrm{PCl}$ condition and a control group.

\section{Long term effects and daily practice: training transference}

The main goal of a training procedure for improving individuals' resources is not only to obtain changes immediately after the intervention, but also to ensure that resources acquired during training will be useful in daily life (Nielsen, Randall, \& Christensen, 2015). As mentioned above, due to the gap in the PCl literature on durability, Dello Russo and Stoykova (2015) conducted a recent replication and extension study to test long-term effects of this micro-intervention. In their student sample, they found significant increases in overall PsyCap levels after training, with these levels remaining stable after one month. Nevertheless, this pattern was not the same in each PsyCap component. For example, levels of resilience and optimism increased after one month, but self-efficacy and hope levels started to decrease right after the intervention. 
Addressing the call to strengthen research on PCl's long-term effects, this study proposes daily practice after workshops as a strategy to promote training transfer and ensure the intervention's effectiveness over time. Training transfer refers to the degree to which training contents are applied in practice in order to ensure that learning outcomes are used by the participants at work (Grohmann \& Kauffeld, 2013). Daily practice activities are very common as a testing procedure in positive interventions (Lyubomirsky \& Layous, 2013; Seligman, Steen, Park, \& Peterson, 2005). This type of procedure encourages daily practice in order to be able to use the skills acquired in a more intensive way in day-to-day activities. For this reason, positive daily practice could be a useful tool to ensure transfer in positive resources interventions, especially short ones, as in the case of micro-interventions. Thus, practicing meaning-focused coping strategies such as positive reinterpretation to manage daily stress could reinforce individuals' PsyCap developed in the workshop and contribute to the sustainability of the effects. Based on usual practitioners' recommendations about the time required to create a habit, stemming from William James' proposals (1890), we expect that long-term effects of $\mathrm{PCl}$ and meaning-focused coping training will be found when training is supported by a meaning-focused coping practice lasting three weeks (DAYI). We formulate the following hypothesis:

Hypothesis 3: Psychological Capital (3a) and psychological well-being (3b) increase significantly after the DAYI Intervention (T2 and T3), compared to their levels prior to the intervention (T1) and compared to a PCI and COPI condition and a control group.

However, stress and coping are essentially conceptualised as an appraisal process (Lazarus, 2006). The frequency and intensity of practising meaning-focused coping every day depend on the participant's stress situation perceptions. In consonance with research approaches that consider the intervention process to more precisely assess the effectiveness of interventions (Nielsen \& Abildgaard, 2013; 
Randall, Griffiths, \& Cox, 2005), the evaluation design was adapted by partitioning the participants' daily practice condition (DAYI) according to their reported frequency of use of the intervention. We formulated the following hypotheses:

Hypothesis 4: Participants who practice meaning-focused coping strategies more frequently use these strategies with more intensity (4a) and report higher levels of psychological capital (4b) after the intervention, compared to participants who use meaning-focused coping strategies less frequently.

\section{Method}

\section{Design and procedure}

This study was part of an institutional project to promote health and well-being in a Spanish university. A free activity called the "Personal and Professional Development Workshop" was offered by email to all undergraduate students. Information about dates, timing, and site was included in the text of the email. Students could register by email, including their preferences for dates and times, and providing contact information. After checking availability, students' participation was confirmed by email, indicating the day and schedule of the workshop.

Groups contained from 2 to 6 participants, and sessions lasted between 3 and 4 hours, depending on the number of participants and their involvement in the different workshop activities. Three facilitators with similar experience in positive interventions and trained in the workshop project were responsible for conducting the intervention. To ensure equity between sessions, we prepared an intervention protocol that was implemented by the facilitators. Sessions were distributed equally among the three facilitators. Experimental conditions and facilitators' schedules were distributed randomly on the calendar before starting the registration period. An online survey was 
sent to participants at 3 different times: 5 days before the workshop, 5 days after the intervention ended, and one month after the intervention ended. Participants who completed the entire activity (workshop and 3 online surveys) could take part in a lottery to win 3 eBooks.

\section{Participants}

The study diagram is shown in Figure 1. At the beginning of the research, 179 students completed the registration. They were then assigned to the 4 randomized conditions. In all, 106 of these students (59\%) attended the workshop. Attendance did not importantly differ by conditions (64\% PCI, 68\% COPI, 52\% DAYI, 50\% CONTROL). The final sample consisted of 56 participants. The primary reason for dropout was not to complete the surveys correctly in each of the 3 periods. Of the 37 participants randomized to the $\mathrm{PCI}$ condition, $51 \%$ answered all surveys. Of the 24 allocated to COPI, $66 \%$ completed all surveys. Of the 31 assigned to DAYI, $45 \%$ responded all surveys. And finally, of the 14 participants randomized to the CONTROL condition, $50 \%$ filled in all the questionnaires. These results of enrollment and retention are similar to other positive interventions (see Moskowitz et al., 2017).

The participants ranged from 18 to 61 years old $\left(M_{a g e}=24.3 ; S D=8.8\right)$, and $68 \%$ were female. They belonged to the four faculties in the University: Faculty of Humanities and Social Sciences (20\%), Faculty of Law and Economics (37\%), School of Technology and Experimental Sciences (13\%), and Faculty of Health Sciences (28\%) (2\% did not provide this information). They belonged to 22 different study programs, and they were studying a 4-year bachelor's degree $(97 \%)$ or a 5 -year bachelor's degree related to the previous curriculum. Thus, $37 \%$ were studying in the first year of their degree program, $22 \%$ in the second, $23 \%$ in the third, $11 \%$ in the fourth, and $3 \%$ in the fifth year, whereas $4 \%$ did not provide their year of study. Finally, $82 \%$ were not working at the time. 


\section{Positive Intervention Process}

Participants were asked to participate in a small-group session in a classroom. Because of the ethical rules of the university, at the beginning of the session, the facilitator repeated and explained the research conditions, and participants signed a consent form. The session required the students' active participation, and so the facilitators encouraged them to provide constructive feedback, ideas, and solutions to the other participants.

Psychological Capital Intervention (PCI) workshop. The intervention was similar to the $\mathrm{PCl}$ model by F. Luthans et al., (2010, 2007). The sessions were composed of different exercises that maintained the following dynamic: brief explanation by the facilitator, individual reflection, and group discussion. Participants chose an important goal related to their studies, focusing on this objective in each of the activities during the workshop. First, facilitators conducted an exercise based on goal-setting and setting specific sub-goals, emphasising the importance of positive formulation, succinctness, and achievement measurement. Once participants had correctly chosen their goals, an activity about planning alternative pathways to attain the goals was conducted. The next step was an exercise about appraising the personal, social, and organizational resources available to achieve the goal, focusing on psychological resources such as personal strengths. Finally, two activities were proposed: designing and implementing obstacles, and training in asset-focused, risk avoidance-focused and process-focused strategies to influence the interpretation of adverse events. At the end of the sessions, participants were encouraged to apply knowledge and skills learned to their student life.

PCI plus meaning-focused Coping Intervention (COPI) workshop. This condition was similar to $\mathrm{PCI}$, but meaning-focused coping contents were added at the end of the workshop. Using the same methodology, facilitators briefly explained the 
concept of stress according to The Cognitive Theory of Stress and Coping (Lazarus \& Folkman, 1984). Then, an exercise about meaning-focused coping was conducted. Facilitators explained three different meaning-focused coping strategies: 1) acceptance, 2) positive reappraisal and benefit finding, and 3) reordering priorities and goal processes. Participants received training in these meaning-focused skills. As in the $\mathrm{PCl}$ model, they practiced thinking about personal important experiences. Strategies such as the self-talk technique were used to teach acceptance of the past, appreciation for the present, and opportunity seeking for the future. In the end, participants were encouraged to apply the knowledge and skills they had learned to their usual goals and tasks at the university.

\section{PCl plus meaning-focused coping workshop plus three-week DAilY} practice Intervention (DAYI). This condition was similar to COPI, but a daily activity for three weeks was proposed to participants to facilitate the transfer of resources acquired during the workshop. A booklet was given to participants as a tool to reinforce the workshop contents. The booklet contained two elements: a list with positive sentences related to acceptance, positive reappraisal and benefit finding, and reordering priorities and goal processes; and a daily self-registration. Facilitators encouraged participants to read a sentence every morning, think about its meaning, and write it down on the daily self-registration, keeping this sentence in mind during the entire study day. Similarly, facilitators encouraged participants to complete the small survey included in the daily self-registration to evaluate the presence of academic stress events, the use of meaning-focused coping strategies, and the emotions related to the use of these strategies. This survey had to be filled out in the evening. At the end of the three weeks, participants returned their booklets to researchers by putting it in a mailbox anonymously. Finally, a post intervention survey was sent to participants by email (3 weeks after the workshop). 
Non related PCl workshop (CONTROL). "Elevator Pitch" training was conducted in this condition. This technique is a short summary used to rapidly and simply define an idea or a project. Facilitators briefly explained the main concepts of this strategy: definition, utility, and benefits of using it. After that, an activity about selfevaluation was conducted, and students were encouraged to think about their personal characteristics, abilities and preferences: all of this was related to their studies. This information was used in the second part of the workshop to practice an "elevator pitch" about a future work project. Participants designed their speech and presented it to the other students and the facilitator, who gave them positive feedback to help them improve.

Figure 1. Study flow chart. 1

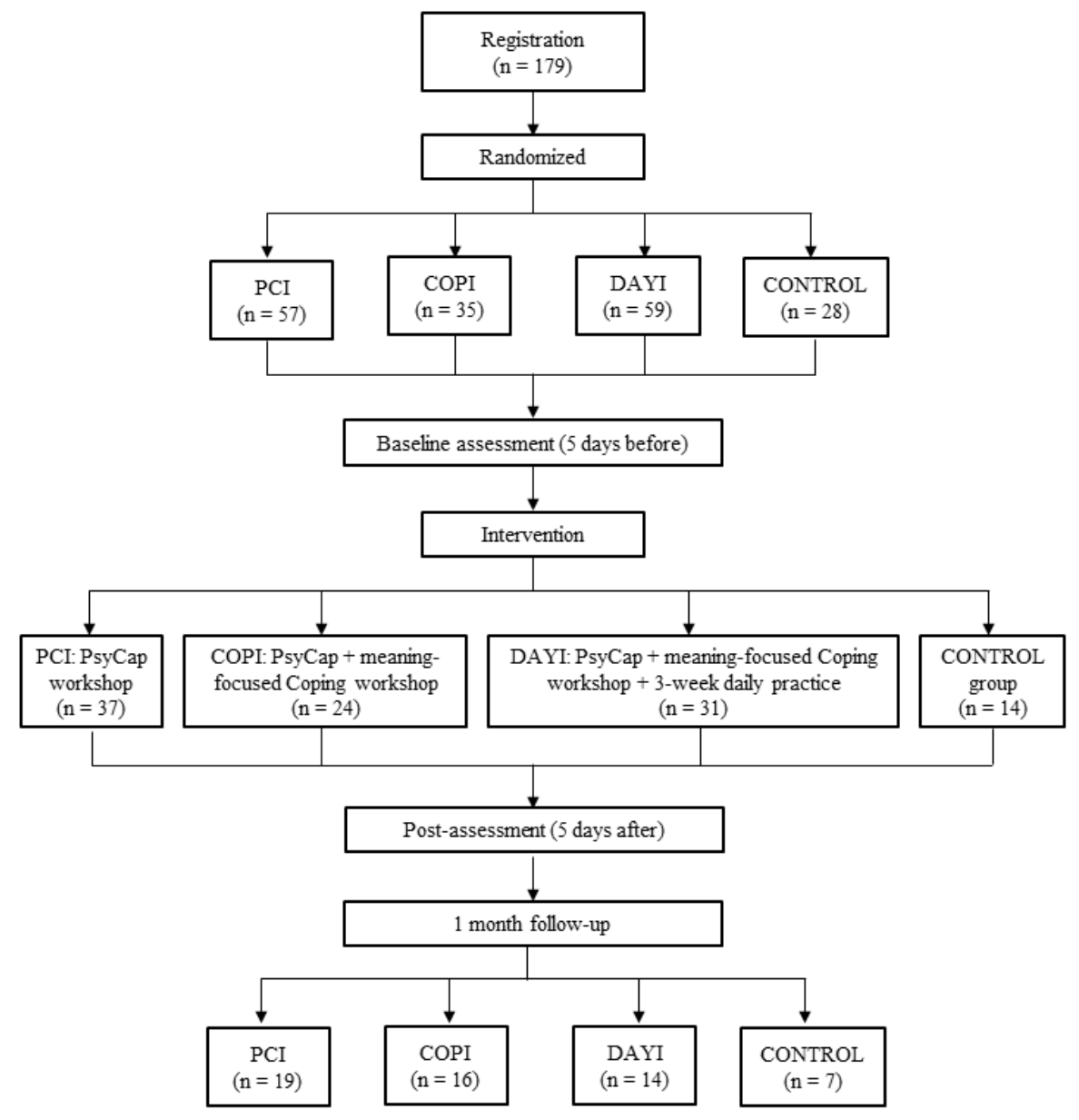




\section{Variables}

Psychological Capital (PsyCap). The 12-item short version of the Psychological Capital Questionnaire (PCQ-12) (Avey, Avolio, \& Luthans, 2011; F. Luthans, Avey, Clapp-Smith, \& Li, 2008), adapted to the academic context, was used to measure participants' PsyCap. The PCQ-12 contains four items to measure hope, three items to measure self-efficacy, three items to measure resilience, and two items to measure optimism. PsyCap is used as a higher-order core construct in which these four components interact in a synergic way (F. Luthans et al., 2015). An example item is: "I can think of many ways to reach my current goals related to my studies". Cronbach's alphas were .86 in T1, .87 in T2, and .90 in T3.

Psychological well-being. The remembered psychological well-being scale of the Pemberton Happiness Index (PHI) (Hervás \& Vázquez, 2013) was used to measure participants' psychological well-being. The PHI remembered well-being scale is an 11-item scale that covers different psychological well-being domains (general, hedonic, eudemonic, and social). It has been validated in a variety of languages, contexts, and countries (Hervás \& Vázquez, 2013). Responses are fully anchored on an eleven-point Likert scale ranging from 0 (totally disagree) to 10 (totally agree). An example item is: "I feel able to solve the majority of my daily problems". Cronbach's alphas were .89 in T1, .86 in T2, and .91 in T3.

Meaning-focused coping. To assess the extent to which participants were using each of the meaning-focused coping strategies in daily academic stress events, they responded to three different questions: "Did you have any stressful situations related to your studies today?" (Yes or not); "How much have you used the acceptance meaning-focused coping strategy?"; "How much have you used the positive reinterpretation meaning-focused coping strategy?" Responses were fully anchored on an eleven-point Likert scale ranging from 0 to 10 . Additionally, affect was evaluated by 
qualitative assessment. Participants were able to write down a small text that answered this question "What did you feel when using these strategies?"

\section{Data analysis}

Data were analysed using IBM SPSS Statistics 23. A repeated-measures MANOVA with a mixed design was used to examine changes in the study variables over time. Covariates were not considered to allow for more liberal testing of the intervention effects, reducing the probability of Type II error. PsyCap was analysed as a core construct, but in order to obtain more specific information, the four PsyCap components (self-efficacy, hope, optimism, and resilience) were computed separately as well.

To answer hypothesis $4 a$ and $4 b$, DAYI participants were divided into two different groups. Due to the small sample size, comparisons between the two groups were analysed using non-parametrical tests. However, small sample sizes may affect statistical power, so we conducted a complementary qualitative analysis for a more comprehensive conclusion. The content of the written material about emotions and coping strategies, included in the daily booklets, was examined. We calculated the frequency of positive and negative emotions that participants declared.

\section{Results}

\section{Previous analysis}

Table 1 shows the reliabilities and correlations between all study variables at the three measurement points. The two dependent variables correlated positively at Time 1 (T1), Time 2 (T2), and Time 3 (T3). 
Table 1. Correlations and Cronbach's alpha coefficients (on the diagonal) of the research variables at T1, T2 and T3.

\begin{tabular}{|c|c|c|c|c|c|c|c|c|c|c|c|c|c|c|c|c|c|c|c|c|}
\hline & 1 & 2 & 3 & 4 & 5 & 6 & 7 & 8 & 9 & 10 & 11 & 12 & 13 & 14 & 15 & 16 & 17 & 18 & 19 & 20 \\
\hline 1. Age & & & & & & & & & & & & & & & & & & & & \\
\hline 2. Gender & -.07 & & & & & & & & & & & & & & & & & & & \\
\hline 3. PsyCap T1 & -.07 & $-.38^{* *}$ & $(.86)$ & & & & & & & & & & & & & & & & & \\
\hline 4. PsyCap T2 & -.01 & $-.30^{*}$ & $.68^{* *}$ & $(.87)$ & & & & & & & & & & & & & & & & \\
\hline 5. PsyCap T3 & -.15 & $-.33^{*}$ & $.61^{* *}$ & $.76^{\star \star}$ & $(.90)$ & & & & & & & & & & & & & & & \\
\hline 6. Self-efficacy T1 & -.03 & $-.41^{\star *}$ & $.70^{\star *}$ & $.39^{\star *}$ & $.31^{\star *}$ & $(.80)$ & & & & & & & & & & & & & & \\
\hline 7. Self-efficacy $T 2$ & -.11 & -.23 & $.37^{\star *}$ & $.65^{\star \star}$ & $.39^{* *}$ & $.49^{\star *}$ & $(.76)$ & & & & & & & & & & & & & \\
\hline 8. Self-efficacy T3 & -.08 & -.26 & $.49^{* *}$ & $.58^{\star *}$ & $.63^{* *}$ & $.59^{\star *}$ & $.65^{* *}$ & $(.82)$ & & & & & & & & & & & & \\
\hline 9. Hope T1 & -.07 & -.23 & $.83^{* *}$ & $.55^{\star *}$ & $.46^{* *}$ & $.43^{\star *}$ & .20 & $.34^{* *}$ & $(.84)$ & & & & & & & & & & & \\
\hline 10. Hope T2 & -.08 & -.11 & $.52^{* *}$ & $.78^{\star *}$ & $.62^{* *}$ & .20 & $.39^{* *}$ & $.45^{\star *}$ & $.63^{* *}$ & $(.78)$ & & & & & & & & & & \\
\hline 11. Hope T3 & -.25 & -.19 & $.46^{* *}$ & $.53^{\star *}$ & $.86^{* *}$ & .10 & .12 & $.39^{* *}$ & $.51^{* *}$ & $.62^{* *}$ & $(.87)$ & & & & & & & & & \\
\hline 12. Optimism T1 & .08 & -.23 & $.58^{* *}$ & $.50^{\star *}$ & $.51^{* \star}$ & $.27^{*}$ & .20 & .25 & $.26^{*}$ & $.29^{*}$ & $.31^{*}$ & (.64) & & & & & & & & \\
\hline
\end{tabular}




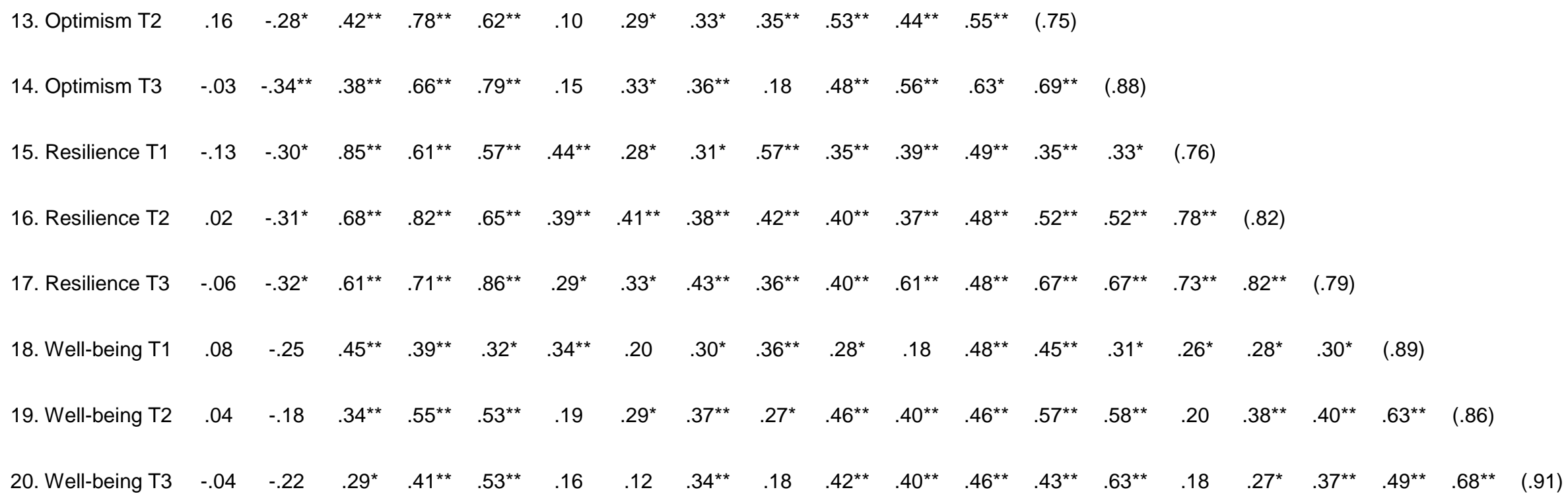


No significant differences were found at T1 in PsyCap $F(3,55)=1.50, p>.05$ or psychological well-being $F(3,55)=1.17, p>.05$ between the three groups in the experimental conditions and the control group. Multivariate homogeneity of variancecovariance matrices assumption was satisfied (Box's M-test $p>.001$ ), and so the robustness of the MANOVA tests was guaranteed.

\section{Time and condition effects}

The multivariate analysis (by repeated-measures MANOVA) of the dependent variables of PsyCap and psychological well-being showed a main effect of change over time (Pillai's Trace $=.304, F=3.426, p=.007$ ). Means and SDs for PsyCap and psychological well-being are presented in Table 2. PsyCap was significantly higher at T2 than at T1, and higher at T3 than at T1 $(p>.01)$. Psychological well-being was significantly higher at T2 than at T1 $(p>.01)$, but the results showed no significant changes from T1 to T3.

However, the interaction effect (time $x$ conditions) was not significant (Pillai's Trace $=.270, F=.809, p=.687)$. Therefore, we tested for the condition effects across time.

\section{PsyCap changes across time}

A central element of the analysis was to compare PsyCap and psychological well-being levels at the three times. First, this involved comparing T1 (before the intervention) and T2 (after the intervention) data in order to assess changes over time in each of the intervention conditions. Second, we compared T1 and T3 (follow up) data to explore sustained effects. Table 3 shows the significant mean differences found. 
Table 2. Means and Standard Deviations at T1, T2 and T3 for the intervention groups and control group.

\begin{tabular}{|c|c|c|c|c|c|c|c|c|c|c|c|c|}
\hline & \multicolumn{4}{|c|}{ PsyCap } & \multicolumn{8}{|c|}{$\begin{array}{l}\text { Psychological well- } \\
\text { being }\end{array}$} \\
\hline & \multicolumn{2}{|c|}{$\overline{T 1}$} & \multicolumn{2}{|c|}{ T2 } & \multicolumn{2}{|c|}{ T3 } & \multicolumn{2}{|c|}{$\overline{T 1}$} & \multicolumn{2}{|c|}{ T2 } & \multicolumn{2}{|c|}{ T3 } \\
\hline & $\mathrm{M}$ & $(S D)$ & $M$ & $(S D)$ & $M$ & $(S D)$ & $M$ & $(S D)$ & $M$ & $(S D)$ & $\mathrm{M}$ & $(S D)$ \\
\hline General & 3.87 & .13 & 4.20 & .11 & 4.27 & .12 & 7.11 & .21 & 7.71 & .17 & 7.45 & .21 \\
\hline $\mathrm{PCl}$ & 4.05 & .20 & 4.30 & .18 & 4.34 & .19 & 7.50 & .34 & 7.70 & .28 & 7.44 & .33 \\
\hline COPI & 3.67 & .22 & 4.12 & .19 & 4.07 & .20 & 6.85 & .37 & 7.57 & .30 & 7.31 & .36 \\
\hline DAYI & 3.57 & .24 & 4.16 & .21 & 4.19 & .22 & 6.62 & .39 & 7.53 & .32 & 7.54 & .39 \\
\hline CONTROL & 4.18 & .33 & 4.22 & .29 & 4.48 & .31 & 7.46 & .56 & 8.01 & .45 & 7.51 & .55 \\
\hline
\end{tabular}

Focusing on the time effects on PsyCap in each condition, results showed significant differences in PsyCap levels between T1 and T2 in COPI $(p>.05)$ and DAYI $(p>.01)$, but there were no significant changes from $\mathrm{T} 1$ to $\mathrm{T} 2$ in $\mathrm{PCl}$ or the control group. Long-term effects were found only in the DAYI condition, where the results showed significant changes in PsyCap levels over time $(p>.01)$.

In order to broaden the information about the results, PsyCap components were analysed separately. Results showed significant differences in Hope and Resilience between T1 and T2. There was a significant change in Hope in the three experimental conditions ( $\mathrm{PCl} p>.05$, COPI $p>.01$ and DAYI $p>.01)$, but there was no significant change in Hope levels in the control group. However, the DAYI group was the only one that showed significant changes in mean levels of Resilience (T1-T2). Moreover, long- 
term effects on Hope $(p>.01)$ and Resilience $\mathrm{PCI}(p>.05)$ levels were again found only in the DAYI condition.

\section{Changes in psychological well-being across time}

The results show significant statistical changes in psychological well-being levels in the COPI and DAYI conditions $(p>.05)$ from T1 to T2. Results for $\mathrm{PCI}$ and the control group were not significant. As Fig.2 shows, long-term effect levels were again found only in the DAYI condition, which shows a moderate significant change between T1 and T3 $(p=.06)$.

Table 3. Mean differences across time.

\begin{tabular}{|c|c|c|c|c|c|c|c|c|}
\hline & \multicolumn{2}{|c|}{ PsyCap } & \multicolumn{2}{|c|}{ Hope } & \multicolumn{2}{|c|}{ Resilience } & \multicolumn{2}{|c|}{ Psychological well-being } \\
\hline & T1-T2 & T1-T3 & T1-T2 & T1-T3 & T1-T2 & T1-T3 & T1-T2 & T1-T3 \\
\hline General & $.33^{\star *}$ & $.40^{\star *}$ & $.50^{\star \star}$ & $.59^{* *}$ & $.45^{\star *}$ & $.45^{\star \star}$ & $.61^{* *}$ & .35 \\
\hline $\mathrm{PCl}$ & .25 & .28 & $.54^{*}$ & $.55^{\dagger}$ & .37 & 38 & .20 & -.06 \\
\hline COPI & $.44^{*}$ & .40 & $.76^{* *}$ & .56 & .40 & 38 & $.72^{*}$ & .46 \\
\hline DAYI & $.60^{\star *}$ & $.63^{* *}$ & $.80^{\star *}$ & $1.00^{* *}$ & $.81^{* *}$ & $.70^{*}$ & $.91^{*}$ & $.93^{\dagger}$ \\
\hline CONTROL & .04 & .30 & .12 & .25 & .24 & .48 & .61 & .05 \\
\hline
\end{tabular}

\section{Daily practice condition effects}

In order to conduct a more comprehensive analysis, the evaluation design was adapted by partitioning the participants' daily practice condition according to their reported frequency of use of the intervention. The use of practice measure showed that 7 participants (50\%) reported using meaning-focused coping strategies on more than half of the days $(M=14.29, S D=1.80)$. Similarly, 7 participants $(50 \%)$ reported using 
these kinds of strategies on less than half of the days during the three weeks of the intervention $(M=5.14, S D=3.13)$.

Non-parametrical analysis (by Wilcoxon signed-rank test) showed that participants who use meaning-focused coping strategies less frequently significantly increase their PsyCap levels from T1 to T2 $(p<.03)$ and from T1 to T3 $(p<.03)$. No significant changes were found in the condition of high use of meaning-focused coping. Moreover, compared to participants who practiced meaning-focused strategies frequently, participants who reported using these strategies less often reported higher levels of intensity on acceptance (0.85) and positive reappraisal $(0.80)$.

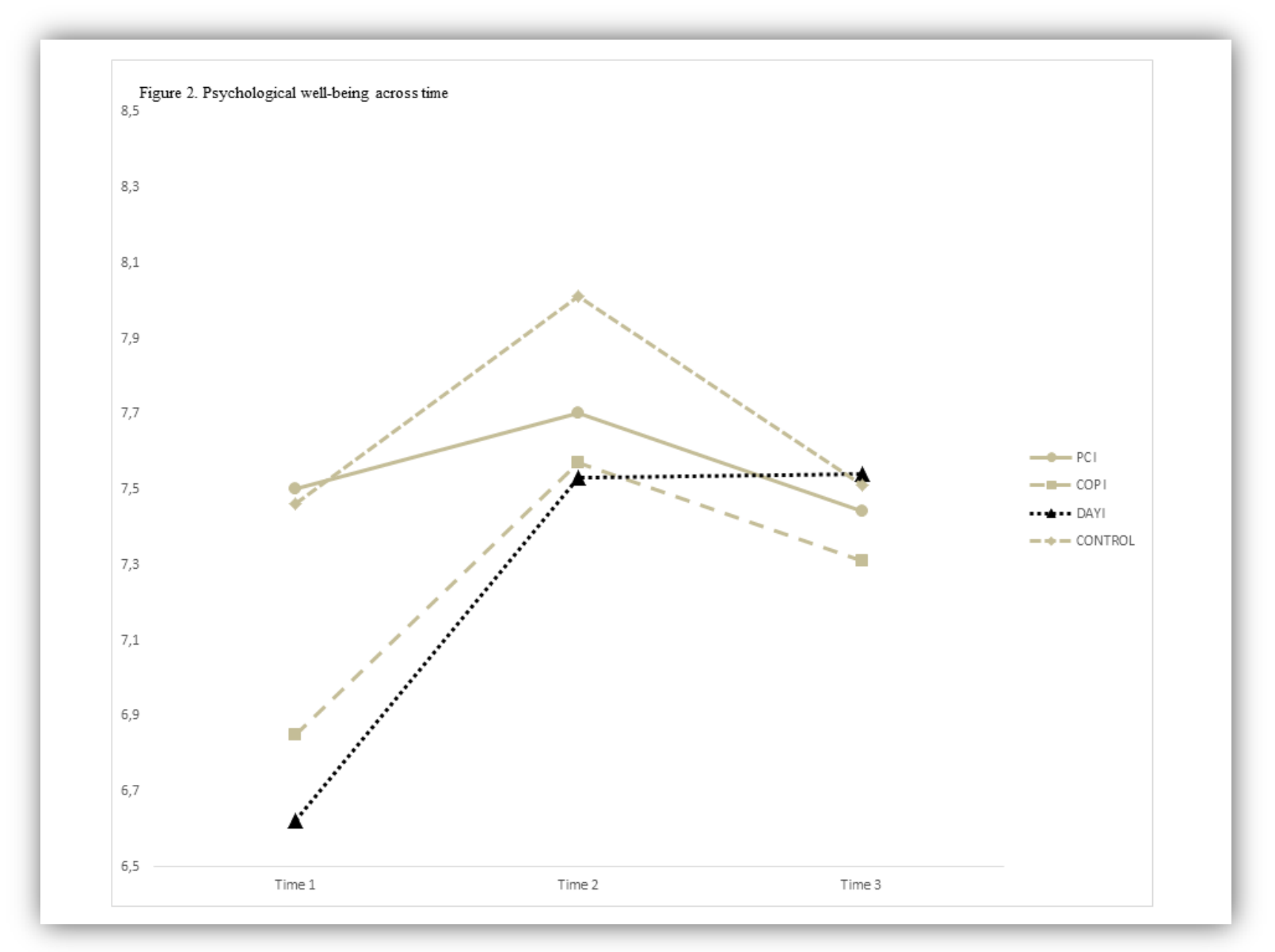

The analysis of the answers to the question about emotions and coping strategies, showed different frequency of positive and negative emotions between both groups. Participants of high use of meaning-focused coping declared $59 \%$ positive 
emotions and $41 \%$ of negative. However, participants who practiced meaning-focused strategies less frequently reported $70 \%$ of positive emotions and $30 \%$ of negative. Regarding to negative emotions, the "higher meaning-focused coping users" reported mostly on the emotions of worry, anxiety and overwhelm. The "lower users" did not repeat any emotions especially. Both groups reported similar positive emotions. Satisfaction, joy and calm were the most repeated.

\section{Discussion}

The aim of this study was to explore the effects of a positive resources combination and daily practice of the PsyCap evidence-based intervention (F. Luthans et al., 2006, 2010; F. Luthans, Avolio, Avey, et al., 2007). The purpose was threefold: to examine effects on PsyCap development, to examine effects on psychological wellbeing development, and to examine longer-term effects. Three groups with different intervention combinations were tested and compared to a control group: PsyCap (micro)Intervention (PCl), PsyCap with meaning-focused COPing (micro)Intervention (COPI), and PsyCap with meaning-focused coping (micro)Intervention plus three weeks of DAily practice (DAYI). Our analyses revealed a within-subject development of PsyCap and psychological well-being over time, with several differences between the experimental conditions.

\section{PsyCap development after interventions}

Regarding PsyCap development after the intervention, compared to the control group, the COPI and DAYI conditions showed significant changes from T1 to T2. Thus, hypotheses (2a) and (3a) were confirmed, supporting meaning-focused coping as a positive psychological resource linked to PsyCap development in educational and work contexts. However, hypothesis (1a) was only partially supported because the $\mathrm{PCl}$ condition did not show significant changes in PsyCap as an overall construct after the intervention, revealing only a significant increase in hope, one of the 
resources that comprise this construct. These results differ somewhat from other studies in the PsyCap literature (B. C. Luthans et al., 2014; F. Luthans et al., 2006, 2010; F. Luthans, Avey, \& Patera, 2008), where PCI was an effective intervention to develop PsyCap levels -as an overall construct- in students and workers. Nevertheless, compared to students who only received $\mathrm{PCI}$ training, students who received the combined PsyCap and meaning-focused coping intervention (COPI and DAYI) reported significantly higher levels of PsyCap after the intervention, revealing their effectiveness for developing PsyCap, as in the aforementioned research.

PsyCap development in the PCI model is based mainly on analysing personal resources to design the best way to complete a task, proactively taking future problems and possible solutions into account. In this study, adding meaning-focused coping training to the PsyCap intervention improved the PCl's effectiveness, helping participants to anticipate potential stressors and take action proactively to prevent them (Folkman, 2009). These results support previous research findings about PsyCap and coping as two related positive psychological resources for college students (Riolli et al., 2012). Moreover, our results showed a special increase in hope and resilience when daily practice of meaning-focused coping was added to the intervention. These two PsyCap components related to persevering and overcoming could explain how PsyCap and meaning-focused coping share psychological mechanisms.

\section{PsyCap's long-term effects}

With regard to PsyCap's long-term effects, hypothesis (3a) was fully supported. The DAYI condition showed significant changes from T1 to T2 that remained constant after a one-month lag (T3). It is interesting to note that sustained effects on PsyCap development were found only when training was supported by meaning-focused coping practice for three weeks. This result showed that practicing meaning-focused coping to manage daily stress was a useful tool to reinforce the 
PsyCap development acquired by participants in the workshop, contributing to the sustainability of the effects. As in previous findings in training transfer research, this study lends additional support to the importance of ensuring that resources acquired during training will be useful in daily life (Nielsen et al., 2015).

Again, these results differ from the Dello Russo and Stoykova (2015) findings on the durability of $\mathrm{PCl}$ effects, which showed significant improvements after one month in overall PsyCap after training. However, our results are not totally different from this previous research. We did not find significant changes between T1 and T3 in $\mathrm{PCl}$ and COPI, but we found a positive increase in PsyCap levels in these conditions (see table 3). Moreover, Dello Russo and Stoykova found that the four resources that comprise PsyCap showed significant differences in their long term effects one month after the intervention. However, this study only showed sustained significant effects on hope and resilience when meaning-focused coping daily practice was added to the intervention, but not on optimism and self-efficacy. Although the differences found are not significant, these two resources showed higher levels in T3 than in T1, so that our results are consistent with this previous research. Further supporting our interpretation, in their study, Dello Russo and Stoykova found different growth patterns in each of the four PsyCap components, showing significant changes in resilience one month after the intervention (follow-up), but not right after the workshop. We accept these differences in development between the PsyCap components, considering possible effects of the "person-activity fit", one of the factors related to the effectiveness of positive interventions (Lyubomirsky \& Layous, 2013). It is possible that participants' different personal characteristics played an important role in single PsyCap components, and this affected their development unequally. 


\section{Psychological well-being effects}

Compared to students who only received PsyCap training, students who received combined PsyCap and meaning-focused coping reported higher levels of psychological well-being after the intervention. Moreover, regarding the long-term effects on psychological well-being, only the DAYI condition showed significant changes from $\mathrm{T} 1$ to $\mathrm{T} 2$ that remained moderately constant after a one month lag (T3). Thus, hypotheses (2b) and (3b) were supported, but hypothesis (1b) was not confirmed. For the first time, the PsyCap intervention has shown an increase in health positive outcomes such as psychological well-being, but this increase was only obtained in the groups that included meaning-focused coping intervention. YoussefMorgan and Luthans (2015) suggested that PsyCap is particularly relevant for wellbeing through a combination of psychological mechanisms, including cognitive and affective positive appraisals, increased satisfaction with important life domains such as education and work, retention of positive memories of valued life events, regular cognitive self-evaluation of one's psychological resources, reductions in prevalent negative bias, and overcoming hedonic adaptation by actively pursuing important life goals. Most of these psychological mechanisms are very close to meaning-focused coping, which is based on the capacity of changing the meaning of stressful events in order to interpret them as challenging instead of harmful or threatening (Folkman, 2009). PsyCap has been shown to empower students with mental strength to cope with adverse circumstances, mediating between stress and psychological well-being (Riolli et al., 2012). The present study sheds light on the importance of meaning-focused coping as a psychological resource for achievement and health, and it furthers our knowledge about the wide range of positive psychological capacities that make up PsyCap. 


\section{Meaning-focused Coping frequency and intensity}

The analysis of the reported frequency and intensity of practising meaningfocused coping every day showed that participants who practiced meaning-focused coping fewer days reported more changes in PsyCap and more intensity in the use of the strategies, compared to participants who practiced more. Thus, hypotheses (4a) and (4b) were not supported at all. In addition, the students of high use of meaningfocused coping declared less positive emotions and more negative emotions than the students who practiced these strategies less frequently. Our interpretation of these results is that these strategies could be used when a student copes with a really stressful situation, and not in daily hassles. According to the reformulated stress and coping model (Folkman, 2008, 2010), problem-focused and emotion-focused coping are the main strategies used to manage a stressful event. Meaning-focused coping becomes useful when this first attempt is not successful, helping to restore the psychological resources and motivation needed to sustain the coping process. Students who use meaning-focused coping in really stressful events could be using it less frequently but more appropriately (Lazarus, 2006), promoting their own PsyCap development, enhancing their levels of positive emotions and diminishing their levels of negative emotions. Another interpretation is related to the importance of personal characteristics such as virtues and strengths, which have been related to college students' coping strategies (Gustems-Carnicer \& Calderón, 2016). In this study, wisdom was related to positive reinterpretation and explained $23 \%$ of the variance in cognitive approach coping (i.e., meaning-focused coping). Thus, a possible explanation for these results would be related to individual differences in strengths and virtues such as wisdom- between participants.

Finally, we consider that the statistical power of the evaluation design may affect to the significance of the results. The sample size of the two final groups after the partition was too small, so these findings are not completely solid. The hypothesis that 
participants who practice meaning-focused coping strategies more frequently use these strategies with more intensity and report higher levels of psychological capital after the intervention shouldn't be refused.

\section{Practical implications}

This study confirms the usability of two strategies to reinforce PsyCap intervention: adding meaning-focused coping content and daily practice after the workshop. Results of this study show that these strategies add value to the intervention, contributing empirical evidence to the PsyCap intervention literature, and responding to the call by $\mathrm{F}$. Luthans et al. (2015) to explore a wide range of positive psychological capacities that make up PsyCap, and by Folkman (2009) to conduct applied meaning-focused coping research. Additionally, for the first time, positive outcomes of the PsyCap intervention in terms of psychological well-being are shown.

These theoretical links, along with the results of the present study, indicate the relevance of considering meaning-focused coping and PsyCap as two complementary psychological resources that can improve students' and workers' fulfilment. College is a very important period in the life of students, and they have to face and cope with many new situations and changes (Arnett 2000). For this reason, scholars should be interested in knowing how to improve psychological capacities related to learning quality and health in the University system. These results have an immediate and practical value for social and educational practitioners who work in organizations and need effective evidence-based interventions.

\section{Limitations}

While exploring how to improve the PsyCap intervention, the study presented here has two main limitations related to the quasi-experimental and actual research design used. First, the sample size and the disparity between the numbers of 
participants in the different groups may affect the statistical power of the analysis. However, this study aimed to be useful both practitioners and researchers, regarding scientific accuracy but also getting as close as possible to fieldwork activities. Like in practitioners' daily work, dropouts appeared and we decided to analyse qualitative data to reinforce and confirm the conclusions of the study. Moreover, the obtained effect sizes were significant in each of the conditions and the findings were innovative. Further research may extend and replicate this study in more diverse and larger samples to improve the generalizability of the results.

Second, we used only one measurement source, i.e. self-reports, and it would be interesting to combine different information sources in future studies. However, the types of variables that we included in our research model were subjective in essence, and so self-report was the recommended measure for this study.

\section{Conclusions and prospective}

According to our findings, PsyCap and meaning-focused coping training with daily practice after the workshop are useful intervention strategies to maintain positive effects on personal resources and well-being over time. Additional directions for future research include testing personal differences in intervention effectiveness, exploring the durability of the intervention effects over longer time frames (e.g., 3, 6 and 12 months), and, especially, increasing the knowledge about interventions on different combinations of personal resources.

Students need to learn technical knowledge in order to become professionals in the future, but they also need to increase other psychological capacities and skills related to performance and work engagement. Practitioners in educational organizations should address this need, and scholars can support them with evidencebased interventions. The better the interventions are, the better the students' quality of life will be. 


\section{References}

Avey, J. B., Avolio, B. J., \& Luthans, F. (2011). Experimentally analyzing the impact of leader positivity on follower positivity and performance. Leadership Quarterly, 22(2), 282-294. http://doi.org/10.1016/j.leaqua.2011.02.004

Avey, J. B., Luthans, F., Smith, R. M., \& Palmer, N. F. (2010). Impact of positive psychological capital on employee well-being over time. Journal of Occupational Health Psychology, 15(1), 17-28. http://doi.org/10.1037/a0016998

Bandura, A. (1997). Self-effi cacy: The exercise of control. New York: Freeman.

Baron, R. a, Franklin, R. J., \& Hmieleski, K. M. (2013). Why Entrepreneurs Often Experience Low, Not High, Levels of Stress: The Joint Effects of Selection and Psychological Capital. Journal of Management, 20(10), 1-27. http://doi.org/10.1177/0149206313495411

Cameron, K. S. (2013). Advances in positive organizational scholarship. In A. B. Bakker (Ed.), Advances in Positive Organizational Psychology (pp. 23-44). Bingley: Emerald Group Publishing. http://doi.org/10.1108/S2046410X(2013)0000001006

Culbertson, S. S., Fullagar, C. J., \& Mills, M. J. (2010). Feeling good and doing great: The relationship between psychological capital and well-being. Journal of Occupational Health Psychology, 15(4), 421-433. http://doi.org/10.1037/a0020720

Datu, J. A. D., \& Valdez, J. P. M. (2015). Psychological Capital Predicts Academic Engagement and Well-Being in Filipino High School Students. The Asia-Pacific Education Researcher, (2001). http://doi.org/10.1007/s40299-015-0254-1 
Dello Russo, S., \& Stoykova, P. (2015). Psychological Capital Intervention (PCI): A Replication and Extension. Human Resource Development Quarterly, 26(3), 329347. http://doi.org/10.1002/hrdq

Folkman, S. (1997). Positive psychological states and coping with severe stress. Social Science and Medicine, 45(8), 1207-1221.

Folkman, S. (2008). The case for positive emotions in the stress process. Anxiety, Stress, and Coping, 21(1), 3-14. http://doi.org/10.1080/10615800701740457

Folkman, S. (2009). Commentary on the Special Section "Theory-Based Approaches to Stress and Coping." European Psychologist, 14(1), 72-77. http://doi.org/10.1027/1016-9040.14.1.72

Folkman, S. (2010). Stress, coping, and hope. Psycho-Oncology, 19(9), 901-8. http://doi.org/10.1002/pon.1836

Folkman, S., \& Moskowitz, J. T. (2000). Positive affect and the other side of coping. American Psychologist, 55(6), 647-654. http://doi.org/10.1037//0003066X.55.6.647

Folkman, S., \& Moskowitz, J. T. (2004). Coping: pitfalls and promise. Annual Review of Psychology, 55, 745-74. http://doi.org/10.1146/annurev.psych.55.090902.141456

Grohmann, A., \& Kauffeld, S. (2013). Evaluating training programs: Development and correlates of the Questionnaire for Professional Training Evaluation. International Journal of Training and Development, 17(2), 135-155. http://doi.org/10.1111/ijtd.12005

Gustems-Carnicer, J., \& Calderón, C. (2016). Virtues and character strengths related to approach coping strategies of college students. Social Psychology of Education, 19(1), 77-95. http://doi.org/10.1007/s11218-015-9305-y 
Hervás, G., \& Vázquez, C. (2013). Construction and validation of a measure of integrative well-being in seven languages: the Pemberton Happiness Index. Health and Quality of Life Outcomes, 11, 66. http://doi.org/10.1186/1477-7525-1166

James, W. (1890). Habit. New York: Henry Holt and Company.

Lazarus, R. S. (1966). Psychological stress and the coping process. New York: McGraw-Hill.

Lazarus, R. S. (2006). Emotions and interpersonal relationships: toward a personcentered conceptualization of emotions and coping. Journal of Personality, 74(1), 9-46. http://doi.org/10.1111/j.1467-6494.2005.00368.x

Lazarus, R. S., \& Folkman, S. (1984). Stress, Appraisal, and Coping. New York: Springer.

Luthans, B. C., Luthans, K. W., \& Avey, J. B. (2014). Building the Leaders of Tomorrow: The Development of Academic Psychological Capital. Journal of Leadership \& Organizational Studies, 21(2), 191-199. http://doi.org/10.1177/1548051813517003

Luthans, F., Avey, J. B., Avolio, B. J., Norman, S. M., \& Combs, G. M. (2006). Psychological capital development: toward a micro-intervention. Journal of Organizational Behavior, 27, 387-393.

Luthans, F., Avey, J. B., Avolio, B. J., \& Peterson, S. J. (2010). The Development and Resulting Performance Impact of Positive Psychological Capital. Human Resource Development Quarterly, 21(1), 41-67. http://doi.org/10.1002/hrdq

Luthans, F., Avey, J. B., Clapp-Smith, R., \& Li, W. (2008). More evidence on the value of Chinese workers' psychological capital: A potentially unlimited competitive 
resource? The International Journal of Human Resource Management, 19(5), 818-827. http://doi.org/10.1080/09585190801991194

Luthans, F., Avey, J. B., \& Patera, J. L. (2008). Experimental Analysis of a Web-Based Training Intervention to Develop Positive Psychological Capital. Academy of Management Learning \& Education, 7(2), 209-221. http://doi.org/10.5465/AMLE.2008.32712618

Luthans, F., Avolio, B. J., Avey, J. B., \& Norman, S. M. (2007). Positive Psychological Capital: Measurement and Relationship with Performance and Satisfaction. Personnel Psychology, 60, 541-572.

Luthans, F., Avolio, B. J., \& Youssef, C. M. (2007). Psychological Capital: Developing the Human Competitive Edge. Oxford University Press.

Luthans, F., Youssef-Morgan, C. M., \& Avolio, B. J. (2015). Psychological Capital and Beyond. New York: Oxford University Press.

Lyubomirsky, S., \& Layous, K. (2013). How Do Simple Positive Activities Increase WellBeing? Current Directions in Psychological Science, 22(1), 57-62. http://doi.org/10.1177/0963721412469809

Masten, a S. (2001). Ordinary magic. Resilience processes in development. The American Psychologist, 56(3), 227-238. http://doi.org/10.1037/0003066X.56.3.227

Moos, R. H. (2002). The Mystery of Human Context and Coping: An Unraveling of Clues. American Journal of Community Psychology, 30(1), 67-88. http://doi.org/10.1023/A:1014372101550

Moskowitz, J. T., Carrico, A. W., Duncan, L. G., Cohn, M. A., Cheung, E. O., Batchelder, A., ... Folkman, S. (2017). Randomized controlled trial of a positive 
affect intervention for people newly diagnosed with HIV. Journal of Consulting and Clinical Psychology, 85(5), 409-423. http://doi.org/10.1037/ccp0000188

Nielsen, K., \& Abildgaard, J. S. (2013). Organizational interventions: A research-based framework for the evaluation of both process and effects. Work \& Stress, (December 2014), 1-20. http://doi.org/10.1080/02678373.2013.812358

Nielsen, K., Randall, R., \& Christensen, K. B. (2015). Do Different Training Conditions Facilitate Team Implementation? A Quasi-Experimental Mixed Methods Study. Journal of Mixed Methods Research. http://doi.org/10.1177/1558689815589050

Ouweneel, E., Le Blanc, P. M., \& Schaufeli, W. B. (2011). Flourishing students: A longitudinal study on positive emotions, personal resources, and study engagement. The Journal of Positive Psychology, 6(2), 142-153. http://doi.org/10.1080/17439760.2011.558847

Rabenu, E., Yaniv, E., \& Elizur, D. (2016). The Relationship between Psychological Capital, Coping with Stress, Well-Being, and Performance. Current Psychology, 1-13. http://doi.org/10.1007/s12144-016-9477-4

Randall, R., Griffiths, A., \& Cox, T. (2005). Evaluating organizational stressmanagement interventions using adapted study designs. European Journal of Work and Organizational Psychology, 14(1), 23-41. http://doi.org/10.1080/13594320444000209

Riolli, L., Savicki, V., \& Richards, J. (2012). Psychological Capital as a Buffer to $\begin{array}{llll}\text { Student } & \text { Stress. } & \text { Psychology, } & \text { 03(12), }\end{array}$ http://doi.org/10.4236/psych.2012.312A178 
Roche, M., Haar, J. M., \& Luthans, F. (2014). The Role of Mindfulness and Psychological Capital on the Well-Being of Leaders. Journal of Occupational Health Psychology, 19(4), 476-489. http://doi.org/10.1037/a0037183

Salanova, M., Llorens, S., \& Rodríguez, A. (2010). Hacia una psicología de la salud ocupacional más positiva. In M. Salanova (Ed.), Psicología de la Salud Ocupacional (pp. 247-284). Madrid: Síntesis.

Seligman, M. E. P. (1998). Learned optimism. New York: Pocket Books.

Seligman, M. E. P., Steen, T. a, Park, N., \& Peterson, C. (2005). Positive psychology progress: empirical validation of interventions. The American Psychologist, 60(5), 410-21. http://doi.org/10.1037/0003-066X.60.5.410

Siu, O. L., Bakker, A. B., \& Jiang, X. (2014). Psychological Capital Among University Students: Relationships with Study Engagement and Intrinsic Motivation. Journal of Happiness Studies, 15(4), 979-994. http://doi.org/10.1007/s10902-013-9459-2

Snyder, C. R. (2000). Handbook of hope. San Diego: Academic Press.

Youssef-Morgan, C. M., \& Luthans, F. (2015). Psychological Capital and Well-being. Stress and Health, 31(3), 180-188. http://doi.org/10.1002/smi.2623 


\section{Chapter 5. The Power of Personal Resources at Work: A Positive Psychological Intervention based on Training Transfer}

A Positive Psychological Intervention (PPI) was designed to increase psychological wellbeing and job performance. This PPI was composed of five workshops to develop psychological capital (PsyCap), meaning-focused coping (MFC), the use of personal strengths, and mindfulness. The literature shows a predictive relationship between these personal resources and desirable outcomes, but it also indicates the importance of training transfer in obtaining sustainable effects. Building on this assumption, we hypothesized that participating in this combined intervention focusing on the transfer of personal resources would contribute not only to increasing these personal resources, but also to increasing psychological wellbeing and job performance in the short and long term. To test these hypotheses, we conducted a field study with a sample of $\mathrm{N}=35$ employees of a Spanish company. First, we tested the post-intervention effects, comparing within and between effects in an experimental condition and a waiting list condition. Second, we tested the sustainability of the effects after 1 month. We analyzed quantitative data from an online questionnaire and qualitative data from a writing exercise collected in the last training session. Results revealed an increase in both the trained personal resources and the associated desirable outcomes after the intervention. Participants reported behaviors transferred to their daily work life, and the effects of PsyCap, MFC, psychological wellbeing, and job performance were maintained over time.

Key words: Workforce Development, Employee Well-Being, Evidence-based HRD, Psychological Capital, Research-Practice Gap, Sustainability, Transfer of Training. ${ }^{4}$

\footnotetext{
${ }^{4}$ Chapter 5 has been submitted for publication as: Ortega-Maldonado, A., Coo, C., \& Salanova, M. The Power of Personal Resources at Work: A Positive Psychological Intervention based on Training Transfer. Human Resource Development Quarterly
} 
Happiness has important consequences for both individuals and organizations, and employees with high psychological wellbeing also perform better (Cropanzano \& Wright, 2001). This is known as the "happy-productive worker hypothesis", which is empirically supported, as revealed by several literature reviews on happiness and wellbeing at work (Fisher, 2010), the job demands-resources theory (Bakker \& Demerouti, 2017), and a recent meta-analysis on workplace resources (Nielsen et al., 2017). A promising strategy to promote happy and productive workers is the development and use of personal resources at work through personal resource interventions (PRI) (F. Luthans \& Youssef-Morgan, 2017; Nielsen et al., 2017). Personal resources are defined as individuals' positive psychological characteristics, beliefs, and capabilities oriented toward accomplishing job tasks and achieving goals (F. Luthans, Youssef-Morgan, \& Avolio, 2015). Investing in PRI is of particular interest to organizations because the use of personal resources is an empirically demonstrated cost-effective strategy (F. Luthans \& Youssef-Morgan, 2017), and because combining different personal resources is related to acquiring stable and desirable behaviors (Fredrickson, 2004).

However, to date, most of the studies on PRI at work have primarily concentrated on the development of only one personal resource, instead of a combination of several personal resources (Van Wingerden, Derks, \& Bakker, 2017). Regarding this research gap, a recent review on workplace resources highlighted the need to explore different training procedures and strategies to optimize the development of personal resources at work and conduct interventions in good conscience (Nielsen et al., 2017). Furthermore, the PRI literature has mainly focused on measuring either psychological wellbeing or job performance as a desirable outcome variable. Thus, considering the happy-productive worker hypothesis, further research is needed to test both variables together. Consequently, filling these gaps is 
of particular interest to organizations because it might contribute to cost-effective interventions for promoting a happy and productive workforce.

Today's organizations have to face dynamic and changing environments, and they need sustainable sources of distinct advantages and a competitive edge (Kraaijenbrink, Spender, \& Groen, 2010). In other words, they need a happy and productive workforce that is stable over time. However, to date, there is insufficient empirical evidence on the long-term effects of PRI, and further research is needed to increase scholars' and practitioners' knowledge about this topic (Dello Russo \& Stoykova, 2015). Training transfer has been found to be a useful strategy for obtaining long-term effects of skills learned at work (see Burke \& Hutchins, 2007 for a training transfer review), but to the best of our knowledge, there is a gap in the empirical evidence about whether personal resource interventions focused on transfer lead to sustainable positive effects.

Addressing these research gaps, this field study evaluates a combined personal resource intervention as an organizational tool to increase psychological wellbeing and employee performance in both the short and long term. Based on previous literature, the intervention consisted of five workshops to develop psychological capital (PsyCap), meaning-focused coping (MFC), the use of personal strengths, and mindfulness, and the intervention also included daily activities to be transferred to daily work life (Nielsen, Randall, \& Christensen, 2015). Our conclusions may help shed light on PRI and contribute to increasing excellence for both Human Resource Development (HRD) scholars and practitioners interested in promoting employee health and wellbeing.

\section{Personal Resources and Happy-productive Workers}

Positive Organizational Behavior (POB) literature suggests that personal resources complement knowledge, talent, and skills, and shape a valuable, rare, and imperfectly imitable asset for the organization that gives it a competitive edge ( $F$. 
Luthans et al., 2015). Using personal resources at work facilitates performance and achievement (see Newman, Ucbasaran, Zhu, \& Hirst, 2014 for a review), which have been proposed as key elements of psychological wellbeing (Seligman, 2011a). Additionally, high levels of personal resources predict psychological wellbeing (Avey, Reichard, Luthans, \& Mhatre, 2011; F. Luthans \& Youssef-Morgan, 2017; Newman et al., 2014), highlighting the importance of personal resources in promoting a happy and productive workforce.

\section{Psychological capital development}

Psychological capital is an extensively researched personal resource that strongly predicts psychological wellbeing and performance at work (see Avey, Reichard, et al., 2011 for a meta-analysis). PsyCap refers to an individual psychological state-like phenomenon (i.e., highly developable), comprised of self-efficacy, hope, optimism, and resilience, which interact synergistically to increase work achievement ( $F$. Luthans \& Youssef-Morgan, 2017). Prior HRD literature has found that PsyCap can be developed through an evidence-based micro-intervention called Psychological Capital Intervention (PCI) (Dello Russo \& Stoykova, 2015; B. C. Luthans, Luthans, \& Avey, 2014; F. Luthans, Avey, Avolio, Norman, \& Combs, 2006; F. Luthans, Avey, Avolio, \& Peterson, 2010). PCl was designed by Fred Luthans and colleagues (2006), who established their intervention model based on previous research on self-efficacy, hope, optimism, and resilience development. This micro-intervention generally consists of a one-to-fourhour group workshop that presents participants a wide range of activities designed to develop each personal resource through several cognitive and affective strategies (F. Luthans \& Youssef-Morgan, 2017).

\section{Psychological capital and meaning-focused coping development}

PsyCap is a goal-oriented personal resource that allows workers to accomplish their tasks even when obstacles arise. Workers constantly face a large number of 
these job obstacles, such as a heavy workload, deadlines, an unfavorable working environment, bureaucracy, etc. (Bakker \& Demerouti, 2017), and they need high and adaptive levels of coping strategies in order to maintain adequate levels of psychological wellbeing and job performance (Folkman, 2008). For this reason, stress management has historically occupied a central place in HRD research and practice, and a recent review on stress management interventions and mental health suggested the importance of developing coping strategies through a positive approach (Richardson, 2017). Meaning-focused coping (MFC) is a positive coping strategy theoretically and empirically linked to PsyCap, psychological wellbeing, and job performance (Dawkins, Martin, Scott, \& Sanderson, 2013; Ortega-Maldonado \& Salanova, 2017). MFC is defined as a stress-assessment cognitive strategy, where the individual draws on his or her beliefs, values, and existential goals to reformulate the perceived demands in a more positive way, viewing them as a challenge instead of a threat (Folkman, 2008). MFC generates positive emotions that help people to manage stress events in a healthier and more efficient way (Folkman, 2008). Consequently, it is related to PsyCap because both of these personal resources may shape a complementary cognitive and affective process related to achieving tasks and goals through positive affect (Dawkins et al., 2013). Both personal resources are based on positive reframing in order to understand and restructure problems in a more positive light, highlighting the importance of meaning-focused coping strategies such as acceptance, finding benefits, positive reframing, and reordering priorities, in order to persevere in achieving goals when facing adversity (Folkman, 2008; F. Luthans \& Youssef-Morgan, 2017). Moreover, MFC has been shown to mediate the relationship between PsyCap and desirable outcomes such as satisfaction and job performance (Ortega-Maldonado \& Salanova, 2017). Based on this prior theoretical and empirical literature, we propose that the combination of PsyCap and MFC interventions might provide a useful HRD strategy for promoting happy-productive workers (Avey, Luthans, \& Jensen, 2009; Ortega-Maldonado \& Salanova, 2017). 


\section{Psychological capital, meaning-focused coping, and use of strengths development}

An essential psychological mechanism involved in PsyCap and MFC development is hope-building, which involves two primary cognitive processes: willpower (agency) and way-power (pathway) (Snyder, 2000). Hope is conceptualized as a positive goal-directed motivational state, and it helps workers to "get started" and "choose the best deal" to meet a goal. A suitable tool for generating different paths to task achievement is knowledge about one's personal strengths, which also predicts greater psychological wellbeing (Meyers et al., 2013). Strengths are defined as positive psychological characteristics that involve an individual's thoughts, feelings, and behaviors (Peterson \& Seligman, 2004). According to the broaden-and-build theory of positive emotions (Fredrickson, 2004) and the conservation of resources theory (COR) (Hobfoll, 2002), employees who use their personal strengths to achieve their jobrelated tasks have a broader behavioral repertoire and, consequently, are better positioned to cope with obstacles and accomplish tasks and goals (Van Woerkom, Bakker, \& Nishii, 2015).

HRD literature on strengths interventions in the workplace is limited. In addressing this gap, Meyers and Van Woerkom (2017) recently found that participating in an intervention to develop the use of personal strengths at work increased psychological wellbeing. Based on these theoretical and empirical links between PsyCap, MFC, and the use of strengths at work, we propose that the combined development of these resources might provide a useful HRD strategy for promoting happy-productive workers. 


\section{Psychological capital, meaning-focused coping, use of strengths, and mindfulness development}

Knowing one's personal strengths implies, by definition, a high capacity for selfawareness. Mindfulness is conceptualized as a self-awareness personal resource that involves attending to the present moment and accepting reality in a non-judgmental manner (Bishop et al., 2004). Some authors have proposed that self-awareness improves the identification and use of personal strengths and promotes a more flexible and balanced evaluation of problems, which facilitates positive reframing and higher achievement (Coo \& Salanova, 2017; Garland, Kiken, Faurot, Palsson, \& Gaylord, 2017). Moreover, increases in Mindfulness have been empirically associated with more frequent use of positive reframing (Garland et al., 2017).

Mindfulness interventions at work are designed to develop participants' selfawareness in the present moment (e.g., task and goal processes), and they include cognitive and affective self-recognition, management of attention, and acceptance exercises. Recent empirical evidence shows the effectiveness of this personal resource intervention in the work context. Coo and Salanova (2017) reported an increase in participants' levels of mindfulness, work engagement, happiness, and job performance after conducting a brief controlled trial of a Mindfulness Based Intervention (MBI). Shonin, Van Gordon, Dunn, Singh, and Griffiths (2014) found a significant and sustainable increase in levels of psychological wellbeing and performance after Meditation Awareness Training (MAT). Based on these theoretical and empirical links between different personal resources, we propose that the combination of PsyCap, MFC, the use of strengths, and mindfulness might provide a useful HRD strategy for promoting happy-productive workers. 


\section{A Combined Personal Resource Intervention Proposal}

Most of the HRD literature on PsyCap, MFC, strengths, and mindfulness provides training procedures and intervention models to explore a significant increase in one personal resource alone. However, combining different personal resources in a PRI program at work has been found to have a significant impact and improve desirable outcomes (Demerouti, Eeuwijk, Snelder, \& Wild, 2011; Ivtzan et al., 2016). Furthermore, Van Wingerden and colleagues (2017) found that combining PRI improved in-role job performance, compared to PRI for developing personal resources alone. To the best of our knowledge, no single study has directly examined the effectiveness and desirable outcomes, in terms of psychological wellbeing and job performance, of a combined intervention on personal resources. Addressing the call to maximize results in a short time frame in organizational settings ( $F$. Luthans, Youssef, \& Avolio, 2007), this Positive Psychological Intervention (PPI) is designed to develop these theoretically and empirically inter-related positive personal resources and promote happy-productive workers. We formulate the following hypotheses:

Hypothesis 1: Personal resources will increase after the intervention (T2), compared to their prior levels $(\mathrm{T} 1)(\mathrm{H} 1 \mathrm{a})$ and compared to the waiting list $(\mathrm{H} 1 \mathrm{~b})$.

Hypothesis 2: Psychological wellbeing and job performance will increase after the intervention (T2), compared to their prior levels $(\mathrm{T} 1)(\mathrm{H} 2 \mathrm{a})$ and compared to the waiting list $(\mathrm{H} 2 \mathrm{~b})$.

\section{Towards sustainability through training transfer}

Today's organizations have to face dynamic and changing environments, and they need sustainable sources with distinct advantages and a competitive edge (Kraaijenbrink et al., 2010). In other words, they need a happy and productive workforce that is stable over time. Combining different personal resources in a PRI 
program at work has been found to have a significant impact and improve desirable outcomes (Demerouti et al., 2011; Ivtzan et al., 2016). Furthermore, Van Wingerden and colleagues (2017) found that combined PRI improved in-role job performance, compared to PRI for developing each of the personal resources alone. Addressing the call to explore different training procedures and intervention models to optimize the development of personal resources (Nielsen et al., 2017), this field study evaluates a PRI consisting of five brief workshops to develop psychological capital (PsyCap), meaning-focused coping (MFC), the use of individual strengths, and mindfulness, along with diary activities designed to be transferred to daily work life (Nielsen et al., 2015). We formulate the following hypotheses:

Hypothesis 3: Participants will declare that behaviors are transferred from the intervention to daily work life after the intervention (T2).

Hypothesis 4: Participants' personal resources (H4a), psychological wellbeing, and job performance $(\mathrm{H} 4 \mathrm{~b})$ will remain higher one month after the intervention (T3), compared to their prior levels (T1).

\section{Method}

\section{Design, Procedure and Participants}

This study was conducted in a national occupational risk prevention company established in three different Spanish areas. The main manager contacted the researchers and asked them to implement an evidence-based Positive Psychology Intervention at the company. To explore the feasibility of the intervention program and ensure that basic hygienic working conditions were present, a preliminary evaluation of psychosocial factors was performed. Then, a personal positive resources development program was offered to the entire workforce. Participation was absolutely voluntary, and there were no additional economic rewards or employee benefits for participants. 
The study was part of a broader research project on Organizational Positive Psychology, and the ethics committee of the University supervised all of the procedures performed.

The company was composed of 44 employees (i.e., prevention technicians, physicians, and administrative staff), 40 of whom (90\%) initially agreed to participate. Non-participants' reasons for declining the invitation were related to time incompatibilities or being on vacation. The program consisted of 5 sessions held once a week on 5 consecutive weeks. Participants were asked to answer an online research questionnaire 3 times during the research period, i.e., before the intervention, immediately after the intervention, and at the one-month follow-up. In order to facilitate the daily activity of the company, and with the researchers' agreement and advice, the main manager assigned the participants to 5 different groups and scheduled the sessions by herself.

The intervention was conducted first in 3 of the groups, which made up the experimental condition (EX) $(n=27)$, and when they finished, the 2 remaining groups (waiting list, $W L)$ started the training $(n=13)$. To avoid disrupting the day-to-day operations of the company, the main manager wanted the WL to start the intervention immediately after the experimental groups' sessions ended, rather than waiting for the follow-up measure to take place. Consequently, the researchers had to adapt the experimental design to ensure the internal validity of the study, and WL participants were asked to fill in the research questionnaire one extra time during the research period. For a more comprehensive view of this field study, the research design and procedure are summarized in figure 1. 


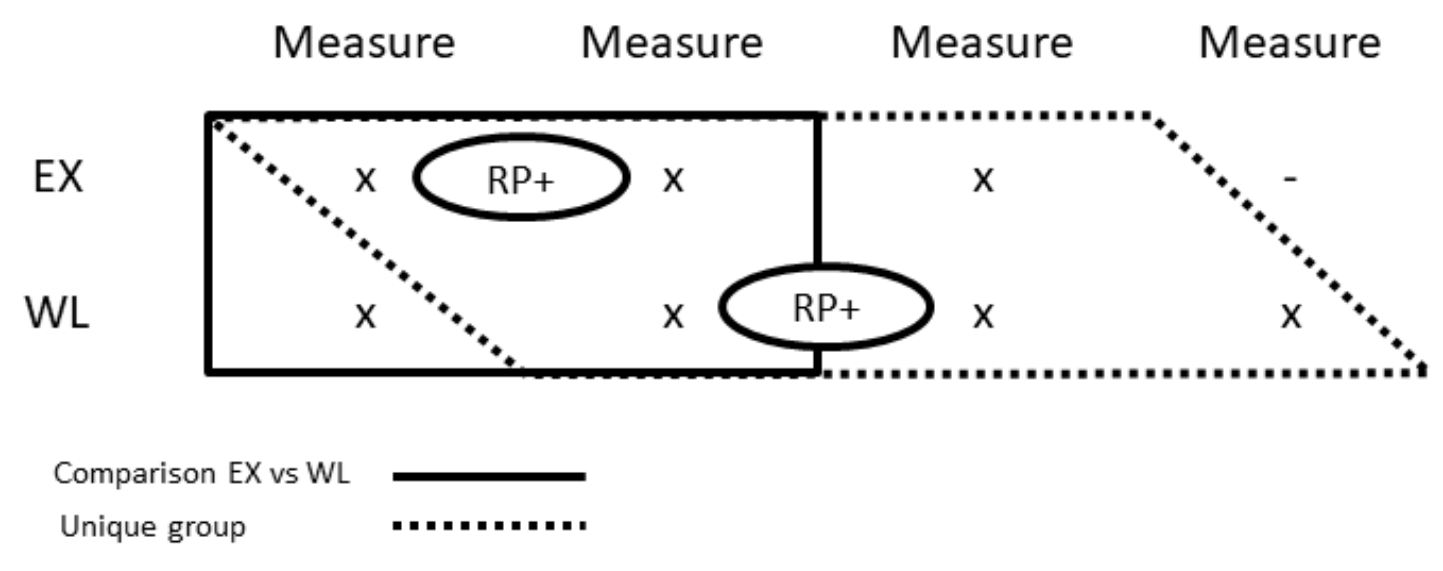

Five participants (3 EX and 2 WL, attrition rate 12.5\%) attended the training sessions, but did not respond to the questionnaires. Attrition analysis (Pearson's chisquare and a $t$-test) revealed no significant differences between the analyzed participants and dropouts on the demographic variables of age $(t(36)=-.582, p=$ $.564)$, tenure $(t(36)=1.057, p=.297)$, and venue $\left(x^{2}(2)=.073, p=.964\right)$. However, there were differences in educational level $\left(X^{2}(3)=8.305, p=.040\right)$, especially in the secondary studies group, and gender $\left(X^{2}(1)=7.900, p=.015\right)$, with women representing the majority of those who remained and the minority of those who dropped out. Thus, we analyzed a final sample consisting of 35 employees. The average age was 38.29 (SD = 7.31, ranging from 29 to 61 ), and $80 \%$ were female. The majority of the participants (74.3\%) were university educated, and their average job tenure was 8.56 years $(S D=4.86$, ranging from 1 to 16$)$. All of them were from Spain.

\section{Intervention Implementation}

The intervention conducted in this study was called "RP+" (derived from the initials of the Spanish words "Recursos Personales Positivos", which means "Positive Personal Resources" in English), a PRI designed by the authors. "RP+" aims to increase participants' psychological wellbeing and job performance through the development of the personal resources of psychological capital, meaning-focused 
coping, use of personal strengths, and mindfulness. Based on organizational PPI literature, participants attended a set of intensive small workshops (F. Luthans et al., 2006), combined with diary activities designed to be transferred to daily work (Nielsen et al., 2015). The RP+ approach is focused on a reinforcement effect through two main intervention strategies: 1) the synergy among the personal resources developed (Van Wingerden et al., 2017) and 2) the transfer of training back to the job tasks (F. Luthans \& Youssef-Morgan, 2017). The intervention model is summarized in figure 2.

The intervention program lasted a total of 5 weeks and consisted of 4 four-hour workshops followed by a two-hour closing session aimed at strengthening the resulting improvement. The intervention design and structure followed a sequential and progressive learning process. Thus, each workshop focused on developing a specific personal resource linked to the prior resource developed. Drawing on the PRI literature, in these workshops, the participants worked individually, in small groups, and all together, promoting social interaction and feedback (Dello Russo \& Stoykova, 2015).

In the first session, the program started with a brief introduction and explanation of the happy-productive worker hypothesis (Cropanzano \& Wright, 2001). Then, a micro-intervention on mindfulness was conducted, based on previous literature (Coo \& Salanova, 2017). Participants practiced basic exercises to learn strategies for developing self-awareness at both formal and informal levels, providing the basis for sustaining a short and fruitful practice.

Session two worked on the use of signature strengths (Peterson \& Seligman, 2004). Based on previous research, a micro-intervention was conducted to identify, develop, and practice personal strengths (Meyers \& Van Woerkom, 2017). Identification was accomplished through activities oriented toward helping participants remember personal experiences when they used their most dominant strengths. Then, 
they analyzed what they did (behaviors), what they thought (cognition and attitudes), and how they felt (emotions) when they used their character strengths at work and in life in general. This analysis was used to design a brief strengths-related plan of action for accomplishing daily tasks at work in the coming week (practice). Finally, an exercise for being mindful and aware of personal strengths was performed in order to reinforce and expand both resources at the same time.

Figure 2. RP+ intervention model.

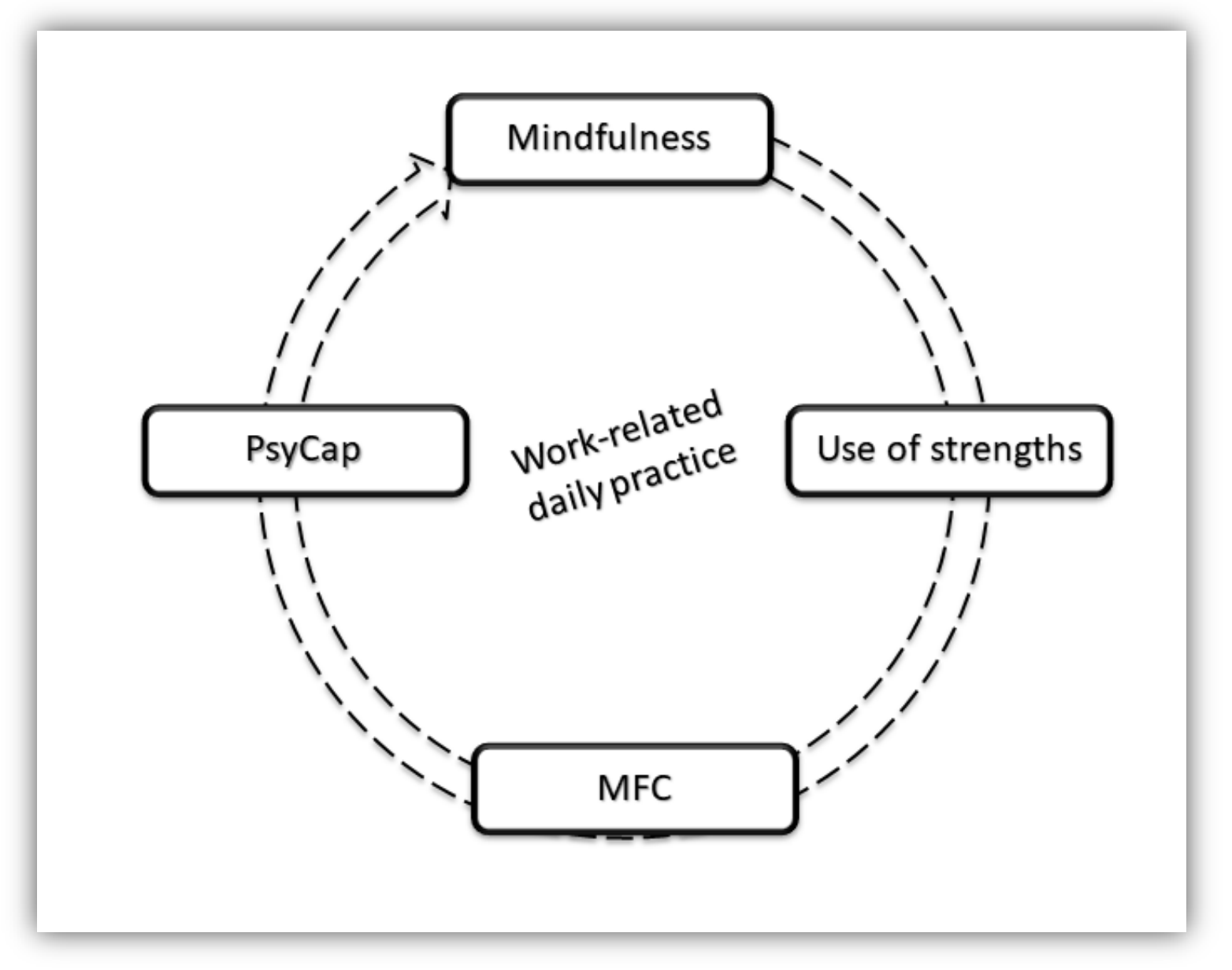

The third session was designed to develop meaning-focused coping. Based on previous stress and coping literature, a workshop was held to explain and train employees to face problems and difficulties with a positive approach (Folkman, 2008). The session focused on modifying the cognitive appraisal process involved during difficulties. Harm and threat appraisals, which are associated with the appearance of 
negative emotions, would be substituted by challenge appraisals, which are associated with positive emotions. Through a personal experienced-based methodology, participants received training in meaning-focused coping strategies, including acceptance, finding benefits, positive reframing, and adaptive goal processes, such as reordering priorities. The previous session was linked to this workshop by using personal strengths as a key resource for practicing the meaning-focused coping strategies. Additionally, related to the first session, participants investigated individual experiences of stress and the underlying appraisals through the mindfulness activity of R.A.I.N meditation (Recognize, Allow, Investigate, and Non-Identify), designed to develop acceptance and positive reframing through self-awareness (Brach, 2004).

The fourth session concentrated on the Psychological Capital Intervention (PCl) (F. Luthans et al., 2006). Following the PCl model, several specific exercises were performed during the workshop to increase participants' levels of each of the four PsyCap components (self-efficacy, hope, optimism, and resilience). These exercises consisted of different cognitive and affective strategies aimed achieving valuable personal and professional tasks and goals. First, participants performed the SMART goal-setting activity (designing Specific, Measurable, Achievable, Relevant and Timebound goals), followed by a stepping exercise (dividing goals into several sub-goals). The previous sessions were linked to PsyCap development by fitting goals to personal values, strengths, and challenges. Then, participants practiced skills of obstacle planning and designing alternative pathways to proactively avoid the risk of adversities. The ABCDE model was taught to enhance the adaptive perception of influence processes when adverse events occur (Seligman, 2011b). This is a cognitive strategy to address life's bad circumstances, be aware of real Adversity, self-related Beliefs, and real Consequences, Dispute personal negative beliefs, and Energize proactive behavior, in order to avoid setbacks by planning obstacles. All three exercises were related to meaning-focused coping. 
Finally, a brief two-hour closing session took place. The main objective of this session was to savor the positive experiences that occurred during the program and strengthen the resulting improvements in personal resources. Both strategies aimed to promote the transfer of the training to the participants' daily work. Additionally, a between-sessions task was offered to participants in order to extend the time frame for transferring the personal resources developed during the workshop to their daily work lives. Two strategies were implemented: a brief five-minute diary training oriented toward putting the personal resources into practice in their daily work (Meyers, Van Woerkom, De Reuver, Bakk, \& Oberski, 2015; Van Wingerden et al., 2017), and messages sent through electronic devices to remind participants of the contents (Rew, Powell, Brown, Becker, \& Slesnick, 2017).

\section{Measures}

Psychological Capital was measured using the Spanish 12-item short version of the Psychological Capital Questionnaire (PCQ-12) (Avey, Avolio, \& Luthans, 2011). The PCQ-12 uses 4 items to measure hope, 3 for self-efficacy, 3 for resilience, and 2 for optimism, considering PsyCap to be higher-order factor in which these four components interact in a synergic way (F. Luthans \& Youssef-Morgan, 2017). Responses were given on a 6-point Likert-type scale ranging from $1=$ "strongly disagree" to $6=$ "strongly agree." Cronbach's alpha for the whole scale over time ranged from .86 to .89 ; for the self-efficacy scale, from .78 to .88 ; for the hope scale, from .80 to .83 ; for the optimism scale, from .67 to .92 ; and for the resilience scale, from .57 to .74 . Cronbach's alpha showed satisfactory levels and guaranteed the reliability of the measure. However, as in previous literature, resilience obtained lower reliability than the other subscales (Dello Russo \& Stoykova, 2015; F. Luthans et al., 2010). 
Meaning-focused coping strategies were measured using the Spanish version of the Brief COPE inventory (Perczek, Carver, Price, \& Pozo-Kaderman, 2000). Based on the meaning-focused coping proposals (Folkman, 2008; Moos, 2002), we used 4 of the subscales included in this questionnaire to measure these variables: acceptance (to assess acceptance), positive reframing (to assess benefit finding and positive reframing), active coping, and instrumental support (both to measure adaptive goal processes and the capacity to reorganize priorities). Each subscale contained 2 items, and we calculated the average of the eight items to calculate the MFC level of each participant. Responses were given on a 4-point Likert-type scale ranging from $0=$ "not at all" to 3 = "a lot". Cronbach's alpha showed satisfactory levels and guaranteed the reliability of the measure, ranging from .85 to .92 for all measurements over time.

Mindfulness was measured using the 20 -item brief scale from the Five Facet Mindfulness Questionnaire (FFMQ) (Baer, Smith, Hopkins, Krietemeyer, \& Toney, 2006), which assesses five different facets of mindfulness (observe, describe, act with awareness, non-reactivity to own thoughts, and non-judgment of own experience), viewing this construct as a higher-order factor. Responses were given on a 7-point Likert-type scale ranging from $0=$ "almost never" to $6=$ "almost always", and half of the items were reverse scored. Cronbach's alpha showed satisfactory levels and guaranteed the reliability of the measure, ranging from .73 to .84 for all measurements over time.

Job performance was measured using the self-evaluated performance scale from the HERO (Healthy \& Resilient Organization) questionnaire (Salanova, Llorens, Cifre, \& Martínez, 2012). We adapted and reworded the 3 items for in-role job performance and the 3 items for extra-role job performance, so that in all cases the referent was the individual instead of the collective. We calculated the average of the 6 items to find out the self-evaluated job performance level of each participant. Responses were given on a 7-point Likert-type scale ranging from $0=$ "never" to $6=$ 
"always". Cronbach's alpha showed satisfactory levels and guaranteed the reliability of the measure, ranging from .84 to .87 for all measurements over time.

Psychological wellbeing was measured using the Pemberton Happiness Index (PHI) (Hervás \& Vázquez, 2013). The PHI is an integrative scale that measures different psychological wellbeing domains: 11 items to assess remembered wellbeing (general, hedonic, eudemonic, and social) and 10 items for experienced wellbeing (positive and negative emotional events that happened the day before). Responses were given on an 11-point Likert-type scale ranging from $0=$ "strongly disagree" to $10=$ "strongly agree" (remembered wellbeing), and a YES/NO type scale related to 10 experiences that occurred the day before (experienced wellbeing). The addition of the 10 experiences formed a $12^{\text {th }}$ variable, and we calculated the average of the 12 variables to find out the level of psychological wellbeing of each participant. Cronbach's alpha showed satisfactory levels and guaranteed the reliability of the measure, ranging from .87 to .89 for all measurements over time.

Finally, the transfer of training was evaluated by a qualitative measure from the savoring exercise conducted in the fifth session. Participants wrote down short phrases answering three questions about each session: 1) What was the main skill learned? 2) What emotions did you feel during the session? and 3) What new behaviors did you acquire and still maintain today?

\section{Analysis Strategy}

First, we investigated the effects of $\mathrm{RP}+$ on the research variables right after the experimental group finished the intervention. Based on previous studies on positive resources development (F. Luthans et al., 2010), we conducted paired-sample $t$-tests for both conditions to explore the mean differences at pre- (T1) and post-intervention (T2). In addition, we conducted several mixed between-within subject analyses of covariance (ANCOVA), with "condition" as between-subject factor and "time" as within- 
subject factor. ANCOVA compared the mean differences for the EX and WL at T2 while controlling for the research variables' values at T1. A total of 29 participants (20 for EX and 9 for WL) responded to the T2 questionnaire. We also calculated the Cohen's $d$ and correlation $r$ as measures of effect sizes in paired-sample $t$-tests, and the partial eta squared in the ANCOVA (Cohen, 1988).

In order to investigate the sustainability of the effects of RP+, we analyzed both conditions together, creating one group (see figure 1). We conducted a pre- (T1), post(T2), and one-month follow-up (T3) measure of all the research variables. We tested for statistical differences using a repeated-measures general linear model (GLM) for each research variable, with "time" (T1, T2, and T3) as the within factor. We also calculated the Cohen's $d$ and the partial eta squared effect sizes (Cohen, 1988).

Finally, in order to optimize the evaluation of this field study, we collected qualitative information from the exercise conducted in the fifth session (F. Luthans \& Youssef-Morgan, 2017; Reio \& Werner, 2017). Based on the available research evidence on evaluating training transfer (Grohmann \& Kauffeld, 2013), we asked participants to write down the main skill learned and the emotions and behaviors related to each resource workshop. We categorized, classified, and analyzed these words based on the specific contents and objectives of the session (learning), the Universe of emotions classification (Bisquerra, 2015; for more information about this classification visit_http://universeofemotions.store/) and the circumplex (Posner, Russell, \& Peterson, 2005) model of affect (emotions), and the behaviors transferred either to their daily work or to life in general. 


\section{Results}

\section{Post intervention effects}

First, we tested whether there were significant differences in the study variables between the experimental $(E X)$ and waiting list (WL) groups prior to the RP+ intervention (T1). We conducted a multivariate analysis of variance (MANOVA), and the results revealed no significant differences (Pillai's Trace $=.344, F(9,19)=1.106, p$ $=.404$, partial $\left.\eta^{2}=.344\right)$. Similarly, the two groups did not differ on the demographic variables of gender $\left(\mathrm{X}^{2}(1)=.079, p=.779\right)$, age $(t(26)=.738, p=.467)$ or tenure $(t$ $(26)=-.372, p=.713)$, and so we concluded that they were comparable.

Table 1 presents the means of each variable for the EX group. Six variables showed an increase in their means from Time 1 to Time 2: PsyCap, hope, resilience, mindfulness, psychological wellbeing, and job performance. This increase ranged from $2.46 \%$ (mindfulness) to $7 \%$ (hope), and obtained small (PsyCap, resilience, mindfulness, and self-rated job performance), intermediate (hope), and large (psychological wellbeing) effect sizes. As table 1 shows, the participants in the EX group reported that two variables increased significantly from Time 1 to Time 2: hope $(\mathrm{T} 1 \mathrm{M}=4.40$ and $\mathrm{T} 2 \mathrm{M}=4.75, t[19]=2.30, p=0.033)$ and psychological wellbeing $(\mathrm{T} 1$ $M=7.08$ and $\mathrm{T} 2 \mathrm{M}=7.46, t[19]=2.81, p=0.011)$. Finally, three variables showed $\mathrm{a}$ slight decrease from Time 1 to Time 2: self-efficacy, optimism, and meaning-focused coping.

Table 2 presents the means of each variable for the WL group. Five variables showed an increase in their means from Time 1 to Time 2: PsyCap, self-efficacy, optimism, meaning-focused coping, and psychological wellbeing. This increase ranged from $1.67 \%$ (PsyCap) to $8.33 \%$ (MFC) and obtained small (PsyCap), intermediate (selfefficacy and optimism), and large (MFC and psychological wellbeing) effect sizes. Unlike the experimental group, as table 2 shows, the participants on the waiting list did 
not report significant increases from Time 1 to Time 2. However, meaning-focused coping ( $\mathrm{T} 1 \mathrm{M}=2.25$ and $\mathrm{T} 2 \mathrm{M}=2.50, t[8]=2.25, p=0.055)$ and psychological wellbeing $(\mathrm{T} 1 \mathrm{M}=6.77$ and $\mathrm{T} 2 \mathrm{M}=7.27, t[8]=2.00, p=0.080)$ obtained increases close to significance. Finally, two variables did not show differences from Time 1 to Time 2 (hope and self-rated job performance), and two reported a decrease (resilience and mindfulness). It is worth noting that resilience obtained a decrease of $2.96 \%$, with a small effect size.

Table 1. Experimental condition. Paired-sample $t$ tests for all study variables (T2-T1)

\begin{tabular}{|c|c|c|c|c|c|c|c|}
\hline & \multirow[t]{2}{*}{ Mean T1 } & \multirow[t]{2}{*}{ Mean T2 } & \multirow[t]{2}{*}{$\%$ increase } & \multirow[t]{2}{*}{$t$-Value } & \multirow[t]{2}{*}{$p$-Value } & \multicolumn{2}{|c|}{ Effect Size } \\
\hline & & & & & & $d$ & $r$ \\
\hline Psychological Capital & 4.54 & 4.70 & 3.20 & 1.26 & 0.221 & $0.24^{*}$ & $0.28^{*}$ \\
\hline Self-efficacy & 5.00 & 4.98 & -0.33 & -0.11 & 0.912 & -0.02 & 0.03 \\
\hline Hope & 4.40 & 4.75 & 7.00 & 2.30 & $0.033^{*}$ & $0.49^{*}$ & $0.47^{\star \star}$ \\
\hline Optimism & 4.27 & 4.22 & -1.00 & -0.21 & 0.834 & -0.04 & 0.05 \\
\hline Resilience & 4.57 & 4.82 & 5.00 & 1.19 & 0.247 & $0.29^{*}$ & $0.26^{*}$ \\
\hline Meaning-focused coping & 2.37 & 2.36 & -0.42 & -0.15 & 0.883 & -0.02 & 0.03 \\
\hline Mindfulness & 3.47 & 3.57 & 2.46 & 0.76 & 0.457 & 0.17 & $0.17^{*}$ \\
\hline Psychological wellbeing & 7.08 & 7.46 & 3.80 & 2.81 & $0.011^{*}$ & $0.29^{*}$ & $0.54^{\star * *}$ \\
\hline Job performance & 4.87 & 5.07 & 3.31 & 1.28 & 0.215 & $0.26^{*}$ & $0.28^{*}$ \\
\hline
\end{tabular}

In order to test whether the T2 variables' values were only due to the experimental condition, above and beyond the initial T1 values, we conducted several mixed between-within subject analyses of covariance (ANCOVAs), which compared the mean differences for the EX and WL at T2 while controlling for the research variables' values at T1. Some authors have proposed that significance is influenced by small sample sizes (Cumming, 2014; Faber \& Fonseca, 2014). Therefore, in order to fully understand the results of the group comparisons, not only the significance tests, 
but also the effect sizes obtained, should be observed (F. Luthans et al., 2010). As tables 1 and 2 show, participants in the EX group had higher increases in PsyCap levels than participants in WL, after the training intervention (1.53\%). The ANCOVA revealed a small effect size effect of the intervention, $F(1,26)=0.368, p=.55, \eta_{p}^{2}=$ .014. Similarly, EX acquired greater increases in two of the PsyCap components that showed an intermediate effect size: hope $(7 \%)\left[F(1,26)=1.638, p=.21, \eta_{p}^{2}=.059\right]$ and resilience $(7.96 \%)\left[F(1,26)=1.663, p=.21, \eta_{p}^{2}=.060\right]$. However, participants in WL had higher increases in optimism than their counterparts (5.44\%), and the ANCOVA revealed a small effect size $\left[F(1,26)=0.330, p=.57, \mathrm{n}_{\mathrm{p}}{ }^{2}=.013\right]$. There were no significant effects or effect sizes for self-efficacy.

Table 2. Waiting List. Paired-sample $t$ tests for all study variables (T2-T1)

\begin{tabular}{lccccccc}
\hline & Mean T1 & Mean T2 & \% increase & $t$-Value & $p$-Value & Effect Size \\
& & & & & \\
& & & & & & \\
& & & & & & \\
& & & & & & \\
\hline
\end{tabular}

With regard to the other study variables, as Tables 1 and 2 also reveal, participants in EX obtained greater increases in mindfulness $(2.63 \%)[F(1,26)=0.444$, $\left.p=.51, \eta_{p}{ }^{2}=.017\right]$ and self-rated job performance $(3.31 \%)[F(1,25)=1.055, p=.31$, $\left.\eta_{p}^{2}=.041\right]$ than participants in $\mathrm{WL}$, after the training intervention. These differences 
demonstrated a small effect size. By contrast, WL participants had greater increases in meaning-focused coping than their counterparts (8.75\%), and the ANCOVA revealed an intermediate effect size $\left[F(1,26)=2.702, p=.11, \eta_{p}^{2}=.094\right]$. Finally, there were no significant effects or effect sizes for psychological wellbeing.

\section{Sustainability of the effects}

In order to investigate the sustainability of the effects of RP+, we analyzed both conditions together in one group. Table 3 presents the means of the study variables for all the workers who participated in the intervention. On first inspection, we can observe an increase in the means from T1 to T2. Only optimism shows an increase from T2 to T3, whereas the rest of the variables show a decreasing pattern that still presents higher scores than baseline on the variables of PsyCap, hope, resilience, MFC, psychological wellbeing, and job performance. GLM analyses showed statistically significant differences in job performance $(F=4.36, p=.02)$ and psychological wellbeing ( $F=5.52, p=.01)$, and close to statistically significant differences in PsyCap $(\mathrm{F}=2.62, p=.09)$ and hope $(\mathrm{F}=3.43, p=.05)$. The pairwise comparisons showed that this difference was significant from T1 to T2 for hope $(p=.04)$ and psychological wellbeing $(p=.01)$, whereas there were no further improvements from T2 to T3.

\section{Qualitative data}

We categorized, classified, and analyzed the variables related to the learning, emotions, and transferred behaviors reported by participants after the last workshop (session 5). Regarding the content learned, participants' phrases focused mostly on one of the workshop objectives in sessions 1 and 2 . Thus, in session $1,70.6 \%$ of the phrases were related to mindfulness (e.g., "Be aware of what I am doing in each moment'), with $19.6 \%$ related to psychological wellbeing, $3.9 \%$ to happiness at work, and $5.9 \%$ to unrelated behaviors. In session $2,76.1 \%$ of the phrases were related to the identification of personal strengths (e.g., "Knowing my strengths"), with $17.4 \%$ 
related to strengths development, $2.2 \%$ to use of strengths, and $4.3 \%$ to unrelated behaviors. Sessions 3 and 4 showed two main topics each. Acceptance (37\%) (e.g., "I have learned to accept problems and see them in another way") and meaning-focused coping as a whole (27.8\%) (e.g., "positive coping") were the main contents reported by participants from session 3. However, finding benefits (5.6\%), positive reframing (13\%), reordering priorities (9.2\%), and unrelated behaviors (7.4\%) were reported less. Finally, two achievement strategies were reported from session 4: goal setting (44.2\%) (e.g., "Define real goals and objectives") and pathway generation (34.6\%) (e.g., "Make a plan to achieve a goal'), whereas obstacle planning (7.7\%), designing potential solutions (11.5\%), and unrelated behavior (2.2\%) were reported less.

Table 3. GLM within-subject effects (T1, T2, and T3)

\begin{tabular}{|c|c|c|c|c|c|c|c|}
\hline & \multirow[t]{2}{*}{ Mean T1 } & \multirow[t]{2}{*}{ Mean T2 } & \multirow[t]{2}{*}{ Mean T3 } & \multirow[t]{2}{*}{ F-Value } & \multirow[t]{2}{*}{$p$-Value } & \multicolumn{2}{|c|}{ Effect Size } \\
\hline & & & & & & $d$ & $\eta_{p}^{2}$ \\
\hline Psychological Capital & 4.48 & 4.71 & 4.59 & 2.62 & $0.094^{\dagger}$ & $0.95^{\star \star \star}$ & $0.18^{\star * *}$ \\
\hline Self-efficacy & 4.93 & 4.97 & 4.69 & 1.20 & 0.320 & $0.64^{\star *}$ & $0.09^{* *}$ \\
\hline Hope & 4.40 & 4.76 & 4.45 & 3.43 & $0.050^{\dagger}$ & $1.09^{* * *}$ & $0.23^{* * *}$ \\
\hline Optimism & 4.16 & 4.30 & 4.46 & 1.20 & 0.320 & $0.64^{\star *}$ & $0.09^{* *}$ \\
\hline Resilience & 4.45 & 4.76 & 4.71 & 1.37 & 0.274 & $0.69^{* *}$ & $0.11^{* *}$ \\
\hline Meaning-focused coping & 2.35 & 2.41 & 2.39 & 0.28 & 0.755 & $0.31^{*}$ & $0.02^{*}$ \\
\hline Mindfulness & 3.37 & 3.47 & 3.37 & 0.49 & 0.616 & $0.41^{*}$ & $0.04^{*}$ \\
\hline Psychological wellbeing & 7.03 & 7.45 & 7.25 & 5.52 & $0.011^{*}$ & $1.38^{\star * *}$ & $0.32^{\star \star \star}$ \\
\hline Job performance & 4.82 & 5.14 & 4.85 & 4.36 & $0.025^{*}$ & $1.26^{\star \star *}$ & $0.28^{* * *}$ \\
\hline
\end{tabular}

As Table 4 shows, we found that $85.5 \%$ of the emotions were positive, whereas negative (6.7\%) and mixed (7.8\%) emotions were much less frequent. The galaxy of happiness (pleasant affective states related to purpose and life satisfaction) (Bisquerra, 2015) was reported most, and it dominated sessions $1(67.3 \%$ of the emotions 
reported), $3(52.6 \%)$ and $4(46.2 \%)$. Specifically, emotions related to low levels of physiological arousal (Posner et al., 2005), such as "calm", "serenity", or "tranquility", were reported more frequently $(74.2 \%$ of the happiness universe in session $1,60 \%$ in session 3 , and $38.8 \%$ in session 4). Session 2 was dominated by the galaxy of joy (emotions produced when a favorable event occurs) (Bisquerra, 2015) (35.7\%), especially by future-oriented emotions such as "optimism" or "excitement", which represented $53.3 \%$ of the galaxy. Moreover, mixed emotions composed of positive and negative feelings (e.g., "surprise") were reported much less in each of the four sessions, and negative emotions (i.e., "frustration", "overwhelm", "anger", and "helplessness") were marginally reported in sessions 2, 3, and 4.

Finally, participants reported behaviors transferred either to their daily work lives or to daily general life. As Figure 3 shows, participants declared higher levels of behaviors transferred to general life in sessions 1 (e.g., "I enjoy routine tasks like shower time" and 2 (e.g., "To give the sufficient level of detail so that the other person can do it'), compared to behaviors transferred to their daily work lives (e.g., "Mindfulness with emails" in session 1, or "Use persistence to meet the established work objectives" in session 2). This difference decreased in session 3 , and the pattern changed in session four, when participants declared higher levels of behaviors transferred to work life (73.8\%) (e.g., "Write down my job goals, and propose deadlines and sub goals"). 
Table 4. Emotions reported related to sessions 1, 2, 3 and 4.

\begin{tabular}{lcccc}
\hline & Session 1 & Session 2 & Session 3 & Session 4 \\
\hline Happiness universe & $67.3 \%$ & $23.8 \%$ & $52.6 \%$ & $46.2 \%$ \\
Joy Universe & $11.0 \%$ & $35.7 \%$ & $18.4 \%$ & $30.8 \%$ \\
Love Universe & $15.2 \%$ & $26.1 \%$ & $5.3 \%$ & $7.7 \%$ \\
Mixed emotions & $6.5 \%$ & $12.0 \%$ & $7.9 \%$ & $5.1 \%$ \\
Negative emotions & $0 \%$ & $2.4 \%$ & $15.8 \%$ & $10.2 \%$ \\
\hline
\end{tabular}

Figure 3. Transfer of training in sessions 1, 2, 3 and 4.

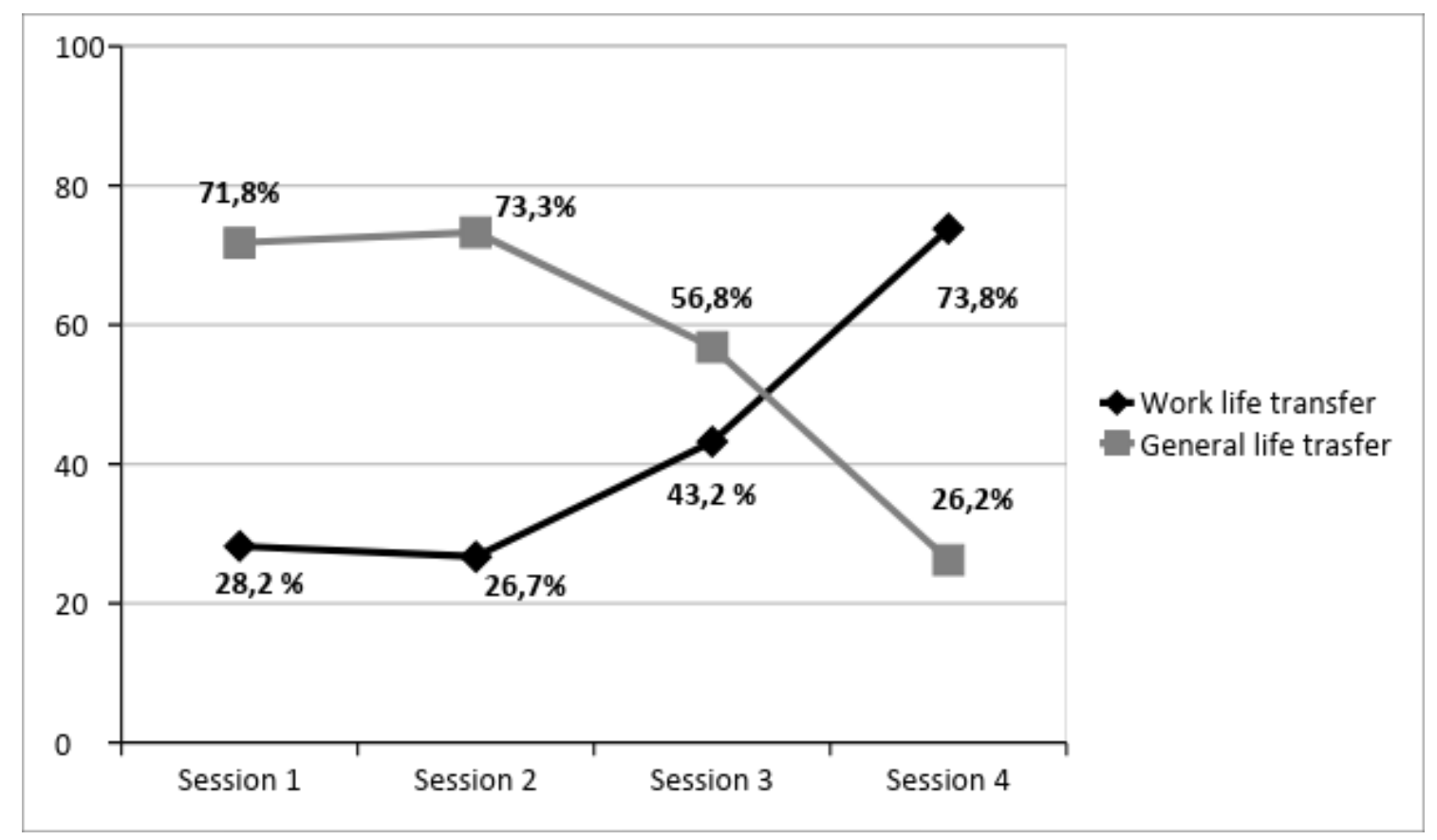

\section{Discussion}

This field study evaluates a personal resource intervention called $\mathrm{RP}+$, conducted in a Spanish company, in order to increase psychological wellbeing and employee performance in the short and long term. We merge three well-established HRD proposals, personal resources development, broadening of personal resources, and 
training transfer, in five workshops designed to increase psychological capital, meaning-focused coping, the use of personal strengths, and mindfulness. We address the call to explore different intervention procedures to optimize the development of personal resources (Nielsen et al., 2017) by adding diary activities to be transferred to daily work life (Nielsen et al., 2015). With the goal of increasing the excellence of the evaluation process, we use a mixed-methods strategy to test the intervention (Reio \& Werner, 2017). Results obtained have a straightforward practical value because the combination of PRI provides a useful HRD strategy for promoting happy-productive workers (Demerouti et al., 2011; Ivtzan et al., 2016; Van Wingerden et al., 2017), and it offers a solution for the need to obtain sustainable effects and maximize the investment (F. Luthans et al., 2015).

\section{Post-intervention effects}

The study results revealed that participants' levels of personal resources increased after the intervention, in both the first and the second stages of the analysis (see figure 1 and table 3). As in previous findings in $\mathrm{PCl}$ research, PsyCap levels improved after the intervention, yielding similar results, in terms of percentages of increase and effect sizes, to those found in previous literature (Dello Russo \& Stoykova, 2015; B. C. Luthans et al., 2014; F. Luthans et al., 2006). However, the PsyCap components did not increase uniformly. Hope and resilience showed greater development than self-efficacy and optimism. We accept these differences in improvement between the PsyCap components, considering both the combined design of $\mathrm{RP}+$ and the role of hope as the cornerstone for developing the other resources. $\mathrm{RP}+$ is focused on reinforcement and a synergic effect in developing personal resources in consecutive interventions, and we consider hope to be the psychological mechanism that links PsyCap, MFC, and the use of strengths for goal achievement (F. Luthans \& Youssef-Morgan, 2017; Snyder, 2000). Additionally, we understand that resilience and MFC are personal resources based on viewing obstacles in a positive 
light, and that an interconnection emerges when both personal resources intervene (Ortega-Maldonado \& Salanova, 2017). In other words, we hypothesize that participants identified their personal strengths, which increased their ability to create different ways to accomplish work tasks, even in adverse circumstances.

Moreover, developing self-awareness through the mindfulness workshop could contribute to this virtuous spiral. In fact, the qualitative information supports this explanation. Participants more frequently reported learning to focus on self-awareness, strength identification, accepting problems, and path generation. Consistent with this, prior research on $\mathrm{PCl}$ found differences between the growth patterns of the PsyCap components (Dello Russo \& Stoykova, 2015), and HRD scholars have called for further research on differences in PsyCap component development through this microintervention (Dawkins \& Martin, 2014; F. Luthans et al., 2010; F. Luthans \& YoussefMorgan, 2017).

Regarding the other personal resources, the results show moderate intervention effects on mindfulness and MFC. An explanation for obtaining less increase in these personal resources than in PsyCap may be related to the trait-state continuum ( $F$. Luthans et al., 2015). Based on HRD evidence, this proposal explains that personal resources differ in their levels of malleability through interventions. PsyCap is classified as "state-like", which means it is open to improvement through a brief PRI. However, our results may suggest that meaning-focused coping and mindfulness could be classified as "trait-like", which means they are more stable. In other words, as prior research shows, we believe that a more extended program should be conducted to obtain a greater increase in mindfulness and meaning-focus coping (Coo \& Salanova, 2017).

Thus, hypothesis H1a was confirmed, supporting RP+ as an effective PRI in the short term. However, hypothesis $\mathrm{H} 1 \mathrm{~b}$, comparing experimental and waiting list 
conditions, was only partially supported. As in prior literature, we observe differences in personal resources development, in favor of the participants who participated in the intervention, on the variables of PsyCap (Dello Russo \& Stoykova, 2015; B. C. Luthans et al., 2014; F. Luthans et al., 2010) and mindfulness (Coo \& Salanova, 2017). However, participants on the waiting list showed greater increases on the self-efficacy and optimism PsyCap components. An explanation for these results may be related to the future-oriented nature of these personal resources (Bandura, 2011; Seligman, 2011b). Thus far, self-efficacy has been related to effectively performing future actions, and optimism has been related to the belief that things will be fine in the future. Waiting list participants could have developed self-efficacy and optimism due to positive group affect contagion (Peñalver, Salanova, Martínez, \& Schaufeli, 2017) from the participants in the experimental group, and the expectation that they would later benefit from the RP + program. The company where the intervention was conducted was a horizontal organization composed of cohesive teams, and we think the daily work life could lead to contagion of the development of personal resources from EX to WL.

Additionally, WL experienced an increase in meaning-focused coping, compared to EX participants. This was an unexpected result. We hypothesize that "person-activity fit", an important variable related to the effectiveness of positive interventions, might influence the workshop's effectiveness (Lyubomirsky \& Layous, 2013). Acceptance, positive reframing, and reordering priorities are not common coping strategies nowadays, and some beginners might find it difficult to understand this approach. The importance of personal characteristics, such as virtues and strengths, in using coping strategies, has been demonstrated (Gustems-Carnicer \& Calderón, 2016), and it is possible that participants' differences play an important role in MFC interventions, affecting their development unequally. We agree with Richardson's (2017) call for further research on positive approaches to stress management in order 
to address important gaps such as the role of personal characteristics as moderator variables in intervention effectiveness (F. Luthans \& Youssef-Morgan, 2017).

Finally, with regard to the desirable outcomes in terms of job performance and psychological wellbeing after the intervention, hypothesis $\mathrm{H} 2 \mathrm{a}$ was confirmed, supporting RP+ as an effective Positive Psychological Intervention for promoting selfreported job performance and psychological wellbeing in the short term. This hypothesis was supported by both the quantitative data analysis (stage 1 and 2) and the qualitative data collected in stage 2 . This qualitative analysis showed a clear predominance of positive emotions, which are considered a key element of psychological wellbeing (Seligman, 2011a). The majority of the positive emotions were related to happiness and joy universes (Bisquerra, 2015), and according to the circumplex model of affect, they had low intensity (Posner et al., 2005). Low arousal but high frequency of positive emotions is related to broader cognitive and behavioral repertories, which contribute to building personal resources. These resources, in turn, help to cope with adversities in a more effective manner, creating a virtuous spiral (Fredrickson, 2004).

However, hypothesis $\mathrm{H} 2 \mathrm{~b}$ was only partially supported. After participating in the intervention, EX participants increased their job performance, whereas WL did not. Nevertheless, those who did not participate in the intervention also increased their psychological wellbeing during this period. This result could be explained again by the evidence-based hypothesis of group positive affect contagion (Peñalver et al., 2017). Moreover, as mentioned above, when this field study was conducted, this company was carrying out an organizational program to increase employees' levels of overall health. We hypothesize that this program could influence the increase in the WL's psychological wellbeing because physiological and psychological health are related (Danner, Snowdon, \& Friesen, 2001). 


\section{Transfer training and sustainability}

Hypothesis 3 generally confirmed the transfer of training. We proposed that participants would state that behaviors were transferred from the intervention to daily work life. As Figure 3 shows, participants reported higher levels of behaviors transferred to general life, mostly related to the beginning of the intervention. Nevertheless, they reported higher levels of behaviors transferred to work life in connection with the $\mathrm{PCl}$. These results are consistent with the intervention design, which proposed more general life-related contents at the beginning of the program, and then performed a more work-related intervention ( $\mathrm{PCl}$ ) ( $\mathrm{F}$. Luthans et al., 2006). Moreover, various studies propose that meaning-focused coping, strengths, and mindfulness are personal resources related to flourishing and adaptive behaviors (Bishop et al., 2004; Lazarus, 2006; Peterson \& Seligman, 2004), and so we hypothesized that improving these personal resources would affect both general life and work life.

Regarding the sustainability of the intervention effects, this study revealed promising results (Dello Russo \& Stoykova, 2015). PsyCap and MFC remained higher than before the intervention at the one-month follow-up measure. However, as prior research on PCI sustainability has found, participants' PsyCap levels did not continue to grow and began to decrease slightly in the long term. We again found differences in PsyCap components, and optimism presented a diverse growth pattern on the followup measure. This heterogeneity in PsyCap component results is consistent with previous research on PsyCap development (Dello Russo \& Stoykova, 2015) and supports the malleability of PsyCap. However, as mentioned above, PsyCap is defined as a state-like personal resource, and examining the long-term effects of an intervention in PsyCap development may not be consistent with this "state-like" definition. We firmly believe that future theoretical reflections and proposals must be elaborated by HRD scholars in order to shed light on this issue. Furthermore, it is 
important to note that participants' mindfulness levels returned to baseline one month after the intervention. As in the case of post-intervention effects, we also relate this result to the need to conduct longer interventions and convert these new skills into habits (Coo \& Salanova, 2017). Thus, hypothesis H4a was partially supported.

In relation to $\mathrm{H} 4 \mathrm{~b}$, participants' levels of psychological wellbeing and job performance remained higher one month after the intervention, compared to their prior levels. However, as in the case of personal resources, they showed a slight decreasing pattern. According to healthy organization models aimed at achieving psychological wellbeing and excellence in work contexts, there are several strategies that organizations proactively perform to obtain happy and productive workers, such as improving job resources (e.g. promoting transformational leaders) or reducing job demands (e.g. less workload) (Bakker \& Demerouti, 2017; Salanova et al., 2012). Organizations are multilevel, dynamic, and complex phenomena, and a broader research focus is necessary for a truthful examination of the effects of personal resource interventions. We call for future research on the role of different organizational strategies in the efficacy and sustainability of personal resources interventions (i.e., the moderator or the mediator) (F. Luthans \& Youssef-Morgan, 2017).

\section{Limitations and Future Research}

The present study is subject to limitations related to the study research design and the sample size. Because this was a field study conducted in a real organization, we had to adapt the research design to the organizational circumstances and some managerial decisions. For example, a randomized assignment of the participants to the experimental conditions was not possible. Similarly, we could not compare the two conditions on the follow-up measure. These limitations may affect the validity of the results. However, a recent literature review on the research-practice gap in applied fields highlights the importance of reinforcing the links between academic research and 
professional practice (Tkachenko, Hahn, \& Peterson, 2017), and field studies seem to be the best strategy for addressing this gap. HDR practitioners usually have to deal with organizations' characteristics, requirements, and preferences while implementing interventions, and this study is an example of these real situations.

Because this was a field study conducted in a real organization, the sample may not be large enough to obtain high statistical power. However, we conducted pairedsample $t$-tests to explore the pre-post differences, complementing ANCOVA and GLM analysis. Otherwise, we did not find statistically significant differences in the majority of our comparisons. However, significance is also influenced by small sample sizes (Cumming, 2014; Faber \& Fonseca, 2014), and in this case, obtaining large effect sizes is a better indication. We found similar or higher effect sizes than what are usually found in positive interventions (see Bolier et al., 2013 for a meta-analysis), and we obtained similar percentages of increases in the research variables to those found in prior literature (Dello Russo \& Stoykova, 2015; F. Luthans et al., 2006). Moreover, HRD scholars have recently been concerned with increasing the excellence of the evaluation process in field studies, and the importance of mixed methods has been emphasized in obtaining quality research (F. Luthans \& Youssef-Morgan, 2017; Reio \& Werner, 2017). In relation to this proposal, previous HRD literature has demonstrated the potential usefulness of mixed methods for a broader evaluation of different aspects of organizational interventions (Abildgaard, Saksvik, \& Nielsen, 2016; Mastenbroek, van Beukelen, Demerouti, Scherpbier, \& Jaarsma, 2015). Thus, we evaluated the intervention through a quantitative (online questionnaires) and qualitative (written evaluation) methodology. However, to extend the research on combined interventions, it would be interesting to replicate this study with larger sample sizes. 


\section{Implications and Conclusions}

We are living in a "VUCA" era, characterized by Volatility, Uncertainty, Complexity, and Ambiguity (Sarkar, 2016), and time is one of the most valuable sources for organizations. They need optimal interventions that maximize results in a short time frame. This field study extends the empirical research on personal resource interventions for promoting happy-productive workers, and it provides an empirical bridge connecting resource-based theory with personal resource interventions (Newman et al., 2014). The combined intervention $\mathrm{RP}+$ obtained promising results through two main intervention strategies: 1) the synergy among the personal resources developed and 2) the transfer of training back to the job task. For the first time, positive outcomes of a combined PRI, in terms of job performance and psychological wellbeing, are evaluated.

Human Resource Development aims to achieve better workers, which means attaining better organizations and, finally, a better world. Conducting and evaluating personal resource interventions is a first step in this process. So no excuses: let's get to work!

\section{References}

Abildgaard, J. S., Saksvik, P., \& Nielsen, K. (2016). How to measure the intervention process? An assessment of qualitative and quantitative approaches to data collection in the process evaluation of organizational interventions. Frontiers in Psychology, 7(SEP), 1-10. https://doi.org/10.3389/fpsyg.2016.01380

Avey, J. B., Avolio, B. J., \& Luthans, F. (2011). Experimentally analyzing the impact of leader positivity on follower positivity and performance. Leadership Quarterly, 22(2), 282-294. https://doi.org/10.1016/j.leaqua.2011.02.004 
Avey, J. B., Luthans, F., \& Jensen, S. M. (2009). Psychological Capital: a positive resource for combating employee stress and turnover. Human Resource Management, 48(5), 677-693. https://doi.org/10.1002/hrm

Avey, J. B., Reichard, R. J., Luthans, F., \& Mhatre, K. H. (2011). Meta-analysis of the impact of positive psychological capital on employee attitudes, behaviors, and performance. Human Resource Development Quarterly, 22(2), 127-152. https://doi.org/10.1002/hrdq.20070

Baer, R. A., Smith, G. T., Hopkins, J., Krietemeyer, J., \& Toney, L. (2006). Using selfreport assessment methods to explore facets of mindfulness. Assessment, 13(1), 27-45. https://doi.org/10.1177/1073191105283504

Bakker, A. B., \& Demerouti, E. (2017). Job demands-resources theory: Taking stock and looking forward. Journal of Occupational Health Psychology, 22(3), 273-285. https://doi.org/10.1037/ocp0000056

Bandura, A. (2011). A Social Cognitive perspective on Positive Psychology. Revista de Psicología Social, 26(1), 7-20. https://doi.org/10.1174/021347411794078444

Bishop, S. R., Lau, M., Shapiro, S., Carlson, L., Anderson, N. D., Carmody, J., ... Devins, G. (2004). Mindfulness: A proposed operational definition. Clinical Psychology: Science and Practice, 11(3), 230-241. https://doi.org/10.1093/clipsy/bph077

Bisquerra, R. (2015). Universo de emociones. Valencia: PaluGea.

Bolier, L., Haverman, M., Westerhof, G. J., Riper, H., Smit, F., \& Bohlmeijer, E. (2013). Positive psychology interventions: a meta-analysis of randomized controlled studies. BMC Public Health, 13(1), 119. https://doi.org/10.1186/1471-2458-13-119

Brach, T. (2004). Radical Acceptance: Embracing your life with the heart of a Buddha. New York: Batam Dell. 
Burke, L. A., \& Hutchins, H. M. (2007). Training transfer: An integrative literature review. Human Resource Development Review, 6(3), 263-296. https://doi.org/10.1177/1534484307303035

Cohen, J. (1988). Statistical Power Analysis for the Behavioral Sciences (2nd ed.). Statistical Power Analysis for the Behavioral Sciences (Vol. 2nd). Hillsdale, NJ: Lawrence Earlbaum Associates. https://doi.org/10.1234/12345678

Coo, C., \& Salanova, M. (2017). Mindfulness Can Make You Happy-and-Productive: A Mindfulness Controlled Trial and Its Effects on Happiness, Work Engagement and Performance. Journal of Happiness Studies, pp. 1-21. https://doi.org/10.1007/s10902-017-9892-8

Cropanzano, R., \& Wright, T. A. (2001). A Review and Further Refinement of the HappyProductive Worker Thesis. Consulting Psychology Journal, 53(3), 182-199. https://doi.org/10.1037//106W087.53.3.182

Cumming, G. (2014). The New Statistics: Why and How. Psychological Science, 25(1), 7-29. https://doi.org/10.1177/0956797613504966

Danner, D. D., Snowdon, D. A., \& Friesen, W. V. (2001). Positive emotions in early life and longevity: Findings from the nun study. Journal of Personality and Social Psychology, 80(5), 804-813. https://doi.org/10.1037//0022-3514.80.5.804

Dawkins, S., \& Martin, A. (2014). Enhancing the psychological capital of teams: Adapting an individual-level intervention for multi-level delivery and evaluation. In R. J. Burke \& A. M. Richardsen (Eds.), Corporate wellness programs: Linking employee and organizational health (pp. 79-100). Northampton, MA, US: Edward Elgar Publishing. https://doi.org/http://dx.doi.org/10.4337/9781783471706.00013 
Dawkins, S., Martin, A., Scott, J., \& Sanderson, K. (2013). Building on the positives: A psychometric review and critical analysis of the construct of Psychological Capital. Journal of Occupational and Organizational Psychology, 86(3), 348-370. https://doi.org/10.1111/joop.12007

Dello Russo, S., \& Stoykova, P. (2015). Psychological Capital Intervention (PCl): A Replication and Extension. Human Resource Development Quarterly, 26(3), 329347. https://doi.org/10.1002/hrdq

Demerouti, E., Eeuwijk, E. Van, Snelder, M., \& Wild, U. (2011). Assessing the effects of a "personal effectiveness" training on psychological capital, assertiveness and selfawareness using self-other agreement. Career Development International, 16(1), 60-81. https://doi.org/10.1108/13620431111107810

Faber, J., \& Fonseca, L. M. (2014). How sample size influences research outcomes. Dental Press Journal of Orthodontics, 19(4), 27-29. https://doi.org/10.1590/21769451.19.4.027-029.ebo

Fisher, C. D. (2010). Happiness at Work. International Journal of Management Reviews, 12(4), 384-412. https://doi.org/10.1111/j.1468-2370.2009.00270.x

Folkman, S. (2008). The case for positive emotions in the stress process. Anxiety, Stress, and Coping, 21(1), 3-14. https://doi.org/10.1080/10615800701740457

Fredrickson, B. L. (2004). The broaden-and-build theory of positive emotions. Philosophical Transactions of the Royal Society of London. Series B, Biological Sciences, 359(1449), 1367-78. https://doi.org/10.1098/rstb.2004.1512

Garland, E. L., Kiken, L. G., Faurot, K., Palsson, O., \& Gaylord, S. A. (2017). Upward Spirals of Mindfulness and Reappraisal: Testing the Mindfulness-to-Meaning 
Theory with Autoregressive Latent Trajectory Modeling. Cognitive Therapy and Research, 41(3), 381-392. https://doi.org/10.1007/s10608-016-9768-y

Grohmann, A., \& Kauffeld, S. (2013). Evaluating training programs: Development and correlates of the Questionnaire for Professional Training Evaluation. International Journal of Training and Development, 17(2), 135-155. https://doi.org/10.1111/ijtd.12005

Gustems-Carnicer, J., \& Calderón, C. (2016). Virtues and character strengths related to approach coping strategies of college students. Social Psychology of Education, 19(1), 77-95. https://doi.org/10.1007/s11218-015-9305-y

Hervás, G., \& Vázquez, C. (2013). Construction and validation of a measure of integrative well-being in seven languages: the Pemberton Happiness Index. Health and Quality of Life Outcomes, 11, 66. https://doi.org/10.1186/1477-7525-11-66

Hobfoll, S. E. (2002). Social and psychological resources and adaptation. Review of General Psychology, 6(4), 307-324. https://doi.org/10.1037/1089-2680.6.4.307

Ivtzan, I., Young, T., Martman, J., Jeffrey, A., Lomas, T., Hart, R., \& Eiroa-Orosa, F. J. (2016). Integrating Mindfulness into Positive Psychology: a Randomised Controlled Trial of an Online Positive Mindfulness Program. Mindfulness, 7(6), 1396-1407. https://doi.org/10.1007/s12671-016-0581-1

Kraaijenbrink, J., Spender, J.-C., \& Groen, A. J. (2010). The Resource-Based View: A Review and Assessment of Its Critiques. Journal of Management, 36(1), 349-372. https://doi.org/10.1177/0149206309350775

Lazarus, R. S. (2006). Emotions and interpersonal relationships: toward a personcentered conceptualization of emotions and coping. Journal of Personality, 74(1), 9-46. https://doi.org/10.1111/j.1467-6494.2005.00368.x 
Luthans, B. C., Luthans, K. W., \& Avey, J. B. (2014). Building the Leaders of Tomorrow: The Development of Academic Psychological Capital. Journal of Leadership \& $\begin{array}{ll}\text { Organizational } \quad \text { Studies, } & \text { 21(2), }\end{array}$ https://doi.org/10.1177/1548051813517003

Luthans, F., Avey, J. B., Avolio, B. J., Norman, S. M., \& Combs, G. M. (2006). Psychological capital development: toward a micro-intervention. Journal of Organizational Behavior, 27, 387-393.

Luthans, F., Avey, J. B., Avolio, B. J., \& Peterson, S. J. (2010). The Development and Resulting Performance Impact of Positive Psychological Capital. Human Resource Development Quarterly, 21(1), 41-67. https://doi.org/10.1002/hrdq

Luthans, F., \& Youssef-Morgan, C. M. (2017). Psychological Capital: An Evidence-Based Positive Approach. Annual Review of Organizational Psychology and Organizational Behavior, 4(1), 339-366. https://doi.org/10.1146/annurevorgpsych-032516-113324

Luthans, F., Youssef-Morgan, C. M., \& Avolio, B. J. (2015). Psychological Capital and Beyond. New York: Oxford University Press.

Luthans, F., Youssef, C. M., \& Avolio, B. J. (2007). Psychological Capital: Developing the Human Competitive Edge. Oxford University Press.

Lyubomirsky, S., \& Layous, K. (2013). How Do Simple Positive Activities Increase WellBeing? Current Directions in Psychological Science, 22(1), 57-62. https://doi.org/10.1177/0963721412469809

Mastenbroek, N., van Beukelen, P., Demerouti, E., Scherpbier, A., \& Jaarsma, D. (2015). Effects of a 1 year development programme for recently graduated veterinary professionals on personal and job resources: A combined quantitative and 
qualitative approach. BMC Veterinary Research, 11(1). https://doi.org/10.1186/s12917-015-0627-y

Meyers, M. C., \& Van Woerkom, M. (2017). Effects of a Strengths Intervention on General and Work-Related Well-Being: The Mediating Role of Positive Affect. Journal of Happiness Studies, 18(3), 671-689. https://doi.org/10.1007/s10902016-9745-x

Meyers, M. C., Van Woerkom, M., \& Bakker, A. B. (2013). The added value of the positive: A literature review of positive psychology interventions in organizations. European Journal of Work and Organizational Psychology, 22(5), 618-632. https://doi.org/10.1080/1359432X.2012.694689

Meyers, M. C., Van Woerkom, M., De Reuver, R. S. M., Bakk, Z., \& Oberski, D. L. (2015). Enhancing psychological capital and personal growth initiative: Working on strengths or deficiencies. Journal of Counseling Psychology, 62(1), 50-62. https://doi.org/10.1037/cou0000050

Moos, R. H. (2002). The Mystery of Human Context and Coping: An Unraveling of Clues. American Journal of Community Psychology, 30(1), 67-88. https://doi.org/10.1023/A:1014372101550

Newman, A., Ucbasaran, D., Zhu, F., \& Hirst, G. (2014). Psychological capital: A review and synthesis. Journal of Organizational Behavior, 25, S120-S138. https://doi.org/10.1002/job.1916

Nielsen, K., Nielsen, M. B., Ogbonnaya, C., Känsälä, M., Saari, E., \& Isaksson, K. (2017). Workplace resources to improve both employee well-being and performance: A systematic review and meta-analysis. Work and Stress, 31(2), 101-120. https://doi.org/10.1080/02678373.2017.1304463 
Nielsen, K., Randall, R., \& Christensen, K. B. (2015). Do Different Training Conditions Facilitate Team Implementation? A Quasi-Experimental Mixed Methods Study. Journal of Mixed Methods Research. https://doi.org/10.1177/1558689815589050

Ortega-Maldonado, A., \& Salanova, M. (2018). Psychological capital and performance among undergraduate students: the role of meaning-focused coping and satisfaction. Teaching in Higher Education, 23(3), 390-402. https://doi.org/10.1080/13562517.2017.1391199

Peñalver, J., Salanova, M., Martínez, I. M., \& Schaufeli, W. B. (2017). Happy-productive groups: How positive affect links to performance through social resources. Journal of Positive Psychology, pp. 1-16. https://doi.org/10.1080/17439760.2017.1402076

Perczek, R., Carver, C. S., Price, A. A., \& Pozo-Kaderman, C. (2000). Coping, Mood, and Aspects of Personality in Spanish Translation and Evidence of Convergence With English Versions. Journal of Personality Assessment, 74(1), 63-87.

Peterson, C., \& Seligman, M. E. P. (2004). Character Strengths and Virtues. Oxord University Press. https://doi.org/313971759

Posner, J., Russell, J. A., \& Peterson, B. S. (2005). The circumplex model of affect: An integrative approach to affective neuroscience, cognitive development, and psychopathology. Development and Psychopathology, 17(3), 715-734. https://doi.org/10.1017/S0954579405050340

Reio, T. G., \& Werner, J. M. (2017). Publishing Mixed Methods Research: Thoughts and Recommendations Concerning Rigor. Human Resource Development Quarterly, 28(4), 439-449. https://doi.org/10.1002/hrdq.21291

Rew, L., Powell, T., Brown, A., Becker, H., \& Slesnick, N. (2017). An Intervention to Enhance Psychological Capital and Health Outcomes in Homeless Female 
Youths. Western Journal of Nursing Research, 39(3), 356-373. https://doi.org/10.1177/0193945916658861

Richardson, K. M. (2017). Managing employee stress and wellness in the new millennium. Journal of Occupational Health Psychology, 22(3), 423-428. https://doi.org/10.1037/ocp0000066

Salanova, M., Llorens, S., Cifre, E., \& Martínez, I. M. (2012). We Need a Hero! Toward a Validation of the Healthy and Resilient Organization (HERO) Model. Group \& Organization Management, $37(6)$, 785-822. https://doi.org/10.1177/1059601112470405

Sarkar, A. (2016). We live in a VUCA World: the importance of responsible leadership. Development and Learning in Organizations: An International Journal, 30(3), 912. https://doi.org/10.1108/DLO-07-2015-0062

Seligman, M. E. P. (2011a). Flourish. Spring, 80-87. https://doi.org/10.1037/0003066X.61.8.772

Seligman, M. E. P. (2011b). Learned Optimism: How to Change Your Mind and Your Life. New York: Vintage. https://doi.org/10.1136/bmj.316.7134.870

Shonin, E., Van Gordon, W., Dunn, T. J., Singh, N. N., \& Griffiths, M. D. (2014). Meditation Awareness Training (MAT) for Work-related Wellbeing and Job Performance: A Randomised Controlled Trial. International Journal of Mental Health and Addiction, 12(6), 806-823. https://doi.org/10.1007/s11469-014-9513-2

Snyder, C. R. (2000). Handbook of hope. San Diego: Academic Press.

Tkachenko, O., Hahn, H.-J., \& Peterson, S. L. (2017). Research-Practice Gap in Applied Fields: An Integrative Literature Review. Human Resource Development Review, 16(3), 235-262. https://doi.org/10.1177/1534484317707562 
Van Wingerden, J., Derks, D., \& Bakker, A. B. (2017). The Impact of Personal Resources and Job Crafting Interventions on Work Engagement and Performance. Human Resource Management, 56(1), 51-67. https://doi.org/10.1002/hrm.21758

Van Woerkom, M., Bakker, A. B., \& Nishii, L. H. (2015). Accumulative job demands and support for strength use: Fine-tuning the JD-R model using COR theory. Academy of Management Proceedings, 2015(1), 12068-12068. https://doi.org/10.5465/AMBPP.2015.321 


\section{Capítulo 6: Conclusiones (español)}

Como se indica en el capítulo introductorio, la presente tesis doctoral está dirigida a profundizar en el conocimiento sobre la aplicación de intervenciones psicológicas positivas (IPP) para desarrollar recursos personales en el ámbito laboral. Para ello, se abordan en primer término las siguientes preguntas de investigación: ¿se confirma la eficacia de las intervenciones psicológicas positivas para desarrollar recursos personales en el trabajo? y ¿qué resultados positivos conlleva el desarrollo de recursos personales a través de intervenciones psicológicas positivas? En segundo lugar, con la intención de investigar acerca la optimización de estas intervenciones, se abordan estas cuestiones: ¿combinar el desarrollo de diferentes recursos personales en una intervención es una buena estrategia para optimizar la eficacia? y ¿la transferencia de intervención es una buena estrategia para mantener los efectos de las intervenciones dirigidas a desarrollar recursos personales?

Para dar respuesta a estas preguntas de investigación, en esta tesis doctoral se presentan diferentes modalidades de estudios tanto en muestras pre-profesionales como profesionales. En primer lugar se muestra una revisión integrativa sobre las publicaciones de intervenciones para desarrollar uno de los recursos personales más investigados en el ámbito laboral: el capital psicológico. Esta revisión permite conocer principalmente si las diferentes intervenciones publicadas hasta la fecha de su redacción son eficaces en términos de incremento de los recursos intervenidos, desempeño y bienestar psicológico. Además compara los resultados obtenidos mediante distintos procedimientos de intervención en diferentes poblaciones de preprofesionales y profesionales a lo largo de varios países, sectores, actividades económicas y tipos de organización. Por último, de la revisión se deducen vinculaciones entre los mecanismos cognitivos intervinientes en dos recursos relacionados con el bienestar psicológico y el desempeño en el trabajo: el capital 
psicológico y de afrontamiento positivo del estrés centrado en el significado. En este sentido aparece como eje central sinérgico entre ambos recursos la capacidad para reformular positivamente las adversidades.

En concordancia con esto, seguidamente en el capítulo tercero se presenta un estudio longitudinal en el ámbito académico sobre la relación entre el capital psicológico, las habilidades de afrontamiento con significado del estrés, la satisfacción como indicador de bienestar, y el desempeño. Este estudio arroja luz sobre la relación teórica y empírica entre ambos recursos personales, y su influencia positiva y significativa tanto en el bienestar psicológico como en el desempeño. Sus resultados sirven para dar soporte teórico-empírico a la propuesta de combinación de intervenciones como estrategia de optimización. Por ello, en los capítulos 4 y 5, como continuación de la investigación hasta el momento presentada, se incluyen dos estudios de campo en los que se miden los efectos de intervenciones que combinan el desarrollo de diversos recursos personales, tanto en población pre-profesional como profesional. En ambos estudios se comparan procedimientos de intervención entre sí y con grupos control o listas de espera, que son de utilidad para profundizar en el conocimiento de la relación procedimiento-sujeto-contexto-eficacia de resultado. Por último, como complemento estos dos estudios evalúan los efectos de la transferencia del entrenamiento a la actividad diaria, para conocer así sus implicaciones en términos de sostenibilidad de las ganancias obtenidas mediante la intervención.

Como se puede deducir tras su lectura, esta tesis doctoral estudia fenómenos de gran complejidad, ya que se analizan procesos individuales en dinámicas grupales y organizacionales, donde una gran variabilidad de condicionantes interactúa entre sí. Por ello, con la intención de abordar este tema de gran composición multivariable, con el foco lo suficientemente amplio, completo y convergente que el fenómeno requiere, en esta tesis se adopta un enfoque de metodología mixta. Se analizan tanto datos cuantitativos como cualitativos, empleándose diversas estrategias estadístico- 
analíticas para obtener la máxima información posible de estos datos. Así a nivel cuantitativo se emplean análisis de modelos de mediación, comparación de medias a través de pruebas $t$, análisis de la varianza y la covarianza univariados y multivariados, así como cálculo de modelos lineales generales. A nivel cualitativo, se emplea análisis de contenido de diversas fuentes de información, como autoregistros o entrevistas escritas. Así mismo, los análisis de resultados abordan tanto los procesos cognitivos, como los conductuales y afectivos, aproximándose todo ello a una visión de $360^{\circ}$ del complejo fenómeno a explicar.

Las conclusiones generales se muestran de forma sintetizada para su mejor comprensión en la figura 1. En las siguientes secciones se abordan tanto las principales implicaciones teóricas como las aplicadas, para concluir con las limitaciones encontradas y las posibles líneas de investigación futuras que dichas limitaciones sugieren.

Figura 1. Modelo integrador de los principales resultados

\section{INTERVENCIONES QUE COMBINAN EL DESARROLLO DE RECURSOS PERSONALES}

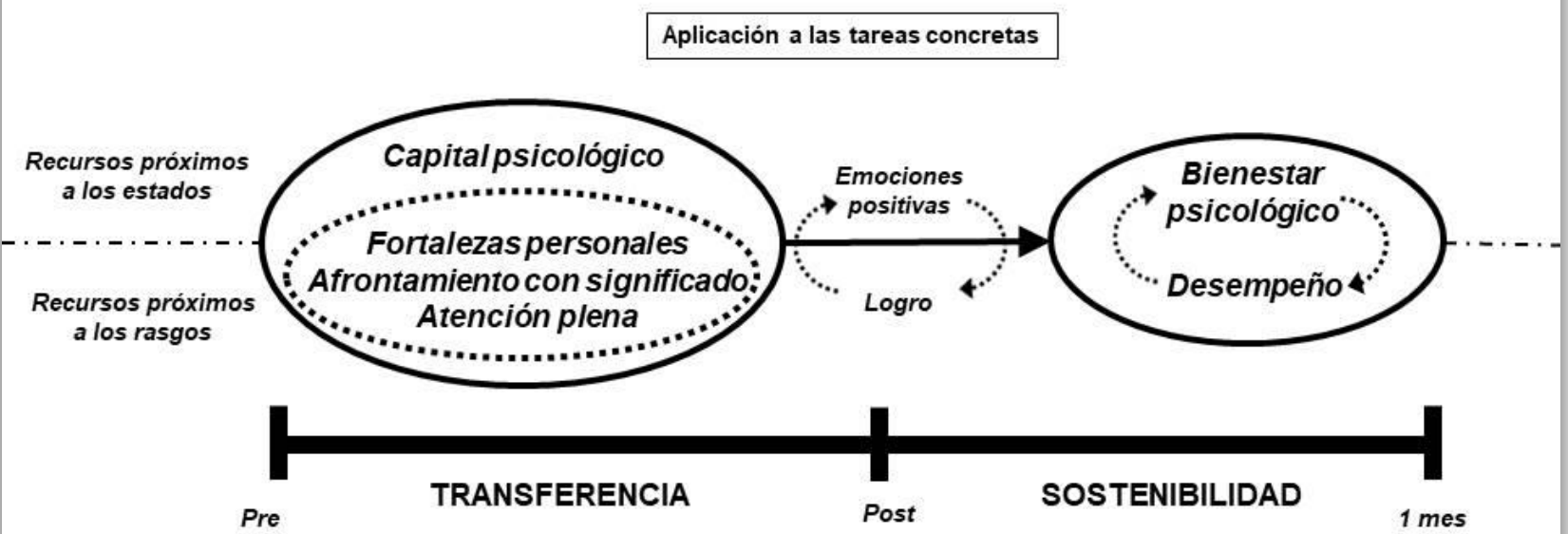

Consolidación de repertorios conductuales 


\section{Principales implicaciones y aportaciones teóricas}

Como se informa en el apartado introductorio, los resultados de investigación de esta tesis doctoral aspiran ser de utilidad a quienes investigan de forma aplicada en Psicología Organizacional Positiva y en Comportamiento Organizacional Positivo, aportando evidencia sobre las IPP dirigidas a desarrollar recursos personales, bienestar psicológico y desempeño. Una síntesis de las conclusiones principales de los diferentes estudios de esta tesis indica que los recursos estudiados (capital psicológico, afrontamiento de adversidades con significado positivo, uso de fortalezas personales y atención plena) muestran una relación interactiva capaz de predecir resultados deseables en términos de bienestar psicológico y desempeño. De especial importancia son las conexiones encontradas entre el capital psicológico y el afrontamiento de adversidades con significado positivo. A nivel teórico, esta tesis viene a reforzar y a ampliar las propuestas que se posicionan en una línea argumental en la que ambos recursos se relacionan a través de mecanismos psicológicos compartidos basados principalmente en la reevaluación de la situación y la reinterpretación positiva (Avey, Reichard, Luthans, y Mhatre, 2011; Dawkins, Martin, Scott, y Sanderson, 2013; Luthans y Youssef-Morgan, 2017; Youssef-Morgan, 2014). En este sentido los hallazgos encontrados a lo largo de los diversos estudios de esta tesis permiten señalar a esta capacidad de reevaluación positiva de situaciones adversas, como una estrategia eficaz para incrementar la probabilidad de éxito en una tarea u objetivo, a través de la motivación por perseverar hacia su consecución.

Además de esta conexión, el capital psicológico y el afrontamiento de adversidades con significado positivo también aparecen vinculados en esta tesis con la atención plena o mindfulness. En este sentido, el desarrollo del mindfulness como habilidad o recurso personal parece estar relacionado con la reevaluación positiva de situaciones estresantes a través de la generación de un estado de conciencia más amplio y flexible, que favorece la aceptación del problema. Así, la conjunción de 
ambas estrategias de afrontamiento de la adversidad con significado positivo (aceptación y reinterpretación) aparece como un mecanismo clave a la hora de realizar evaluaciones y análisis contextuales (Folkman, 2008), permitiendo por tanto una interpretación favorable de dicha adversidad (Garland, Kiken, Faurot, Palsson, y Gaylord, 2017). Esta capacidad de las personas de transformar cognitivamente el significado otorgado a un problema desde la amenaza hacia el reto, les permite alcanzar un nuevo marco conductual y afectivo, configurando a través de la resiliencia y el uso de fortalezas personales un repertorio más adaptativo generador de más posibilidades de éxito y bienestar psicológico, incluso cuando el entorno o los condicionantes no son favorables (Folkman, 2008; Fredrickson, 2004; Luthans, Youssef-Morgan, y Avolio, 2015).

\section{Crecer en la adversidad: el aporte de la Psicología Positiva en la gestión de situaciones negativas}

Es de destacar que en la investigación en Psicología Positiva se ha centrado desde su inicio en el incremento de emociones positivas y el decremento de emociones negativas como elemento fundamental para aumentar la felicidad (Seligman, 2011). De hecho, este enfoque ha provocado críticas debido al rol denostado que otorga a las emociones negativas y a los eventos traumáticos o desfavorables propios de la vida, a los que este tipo de emociones están asociadas (Lazarus, 2003). Sin embargo, considerar la aceptación como una buena estrategia adaptativa ante problemas y adversidades, puede ofrecer un nuevo enfoque sobre el papel de las emociones negativas en el bienestar psicológico, que sostiene la gestión de este tipo de emociones a través de su aceptación como una estrategia cognitivoafectiva esencial para tener una vida plena incluso cuando las circunstancias no son favorables. La aceptación por tanto, se constituye como un mecanismo adaptativo para normalizar el mundo como un entorno que en ocasiones es hostil y desfavorable, y ayuda a la persona a permitirse sentir emociones negativas y a valorarlas como un 
elemento transformador (Lazarus, 2006). Esta gestión adaptativa de las emociones negativas puede, por tanto, contribuir a una reformulación del paradigma afectivo en Psicología Positiva. En esta reformulación se entiende la posibilidad de construir vidas plenas a través de IPP dirigidas tanto a la potenciación de las oportunidades y las fortalezas (Parks y Biswas-Diener, 2013) como a la trasformación de las adversidades y reveses (Moskowitz et al., 2017), aportando, por tanto, este trabajo doctoral un enfoque positivo de intervención en la gestión del estrés (Richardson, 2017).

\section{Combinar recursos para lograr espirales virtuosas}

Por otro lado los mecanismos de sinergia e interactividad entre los recursos personales estudiados, se basan en la generación de espirales virtuosa (Salanova, Llorens, y Schaufeli, 2011) (ver figura 1). Así mediante esta interacción se contribuye a crear un repertorio más amplio de recursos, que a través de la generación de emociones positivas, se amplia y consolida, creando de esta forma una espiral virtuosa (Fredrickson, 2004; Hobfoll, 2002; Luthans y Youssef-Morgan, 2017). Como se muestra en la figura 1, esta espiral producto de la interacción de recursos, ocurre entre aquellos de tipo menos estable (próximos a los estados y estrechamente vinculados con la consecución de tareas) y aquellos más estables (próximos a los rasgos y relacionados con el crecimiento personal). Por este motivo, los resultados mostrados en la presente tesis doctoral otorgan importancia a situar el capital psicológico como un recurso próximo a estado que, a través de ciertos mecanismos, puede influir en el desarrollo de recursos más estables, los cuales a su vez, pueden contribuir al desarrollo del pleno potencial de una persona en una organización (Newman, Ucbasaran, Zhu, y Hirst, 2014; Youssef-Morgan, 2014).

De hecho, en relación a estos mecanismos subyacentes, se ha encontrado que los cuatro componentes del capital psicológico (autoeficacia, optimismo, esperanza y resiliencia), además de conformar un constructo de segundo orden en el que 
interaccionan entre sí, explican de forma individual la variabilidad de actitudes y comportamientos asociados (Luthans y Youssef-Morgan, 2017). Es decir, no sólo afectan al desempeño y bienestar psicológico conjuntamente, sino que también lo hacen de forma individual. Por ello, y teniendo en cuenta las definiciones de cada uno de estos componentes, cabe plantearse que éstos formen parte de forma separada de los mecanismos de conexión entre el capital psicológico y aquellos recursos más estables, como por ejemplo la atención plena y el afrontamiento positivo a las adversidades. En relación con esta idea, y atendiendo a la llamada a la investigación a estudiar de forma individual cada uno de estos componentes (Youssef-Morgan, 2014), otra de las aportaciones de este trabajo doctoral se corresponde con los resultados obtenidos sobre sus diferentes patrones de crecimiento y desarrollo a través de las intervenciones llevadas a cabo. Por tanto, parece interesante explorar este camino en investigaciones futuras, para conocer cómo el desarrollo de cada uno de los componentes del capital psicológico influye en el desarrollo de otros recursos más estables también relacionados con el bienestar psicológico y el desempeño.

En resumen la evidencia empírica demostrada en la presente tesis doctoral, viene a contribuir teóricamente al cuerpo de investigación en IPP postulando la combinación del desarrollo de recursos personales en una misma intervención, como estrategia organizacional para incrementar los niveles de bienestar psicológico y desempeño de las personas en el ámbito laboral. Es decir, estos resultados empíricos arrojan luz sobre cómo optimizar las intervenciones positivas para promover plantillas felices y productivas (Cropanzano y Wright, 2001).

\section{Principales implicaciones y aportaciones prácticas}

La relación bienestar-desempeño en las organizaciones ocupa hoy en día un papel importante tanto en el ámbito de académico como profesional (Litchfield, Cooper, Hancock, y Watt, 2016; Nielsen et al., 2017). Por ello, como se indica en el 
capítulo introductorio, los resultados de este trabajo doctoral aspiran a servir tanto a quienes investigan de forma aplicada, como a quienes trabajan de forma profesional en el ámbito de la Psicología Organizacional Positiva y el Comportamiento Organizacional Positivo. Así se aporta evidencia sobre intervenciones eficaces para incrementar recursos personales en el trabajo que, además, logran mejorar los niveles de bienestar psicológico y desempeño en quienes participan.

De igual modo, se aporta evidencia sobre procedimientos capaces optimizar estas intervenciones positivas. En este sentido, dos estrategias son las que se ponen principalmente a prueba: la combinación del desarrollo de diferentes recursos personales, y la transferencia de entrenamiento a la actividad laboral diaria. A nivel general, las dos intervenciones presentadas en los capítulos 4 y 5 , indican que tanto la combinación de desarrollo de recursos personales como la transferencia, influyen favorablemente en la sostenibilidad de los efectos conseguidos al finalizar la intervención, al menos en el plazo de un mes después de que acabaran las mismas. Así el estudio del capítulo 4 refleja que combinar el desarrollo de capital psicológico con el desarrollo de afrontamiento de adversidades basado en la aceptación y reevaluación positiva, es más efectivo para incrementar los niveles de capital psicológico, así como para aumentar el bienestar asociado. Además, esta mayor efectividad no aparece sólo justo después de la intervención, sino que además la combinación de intervenciones es capaz de mantener sus efectos un mes después. Particularmente esto sucede cuando se incorpora práctica diaria posterior a la intervención para fomentar la transferencia, lo que ayuda a consolidar el repertorio conductual adquirido mediante la valoración de experiencias de logro que generan emociones positivas (Burke y Hutchins, 2007; Fredrickson, 2004; Hobfoll, 2002; Linley, Nielsen, Gillett, y Biswas-Diener, 2010; Seligman, 2011).

Medir los efectos a largo plazo de las intervenciones dirigidas a desarrollar recursos personales es necesario y útil para poder incrementar la confianza en 
profesionales y responsables organizacionales a la hora de invertir en este tipo de acciones (Dello Russo y Stoykova, 2015; Youssef-Morgan, 2014). Pero también es importante lograr transferencia de estas intervenciones a la actividad diaria para consolidar el incremento obtenido a través de esta intervención (Burke y Hutchins, 2007; Luthans y Youssef-Morgan, 2017). Por tanto, la presente tesis doctoral se alinea con esta necesidad y da respuesta a la misma a través los principales resultados obtenidos.

\section{“RP+": un programa que añade el desarrollo de más recursos personales}

Como se ha venido mencionando a lo largo de toda esta tesis, actualmente en el campo del desarrollo de personas en el ámbito laboral es fundamental alcanzar un grado de transformación mayor y más duradera (Le Blanc y Oerlemans, 2016). Por ello, como estrategia para optimizar la efectividad, es necesario profundizar en el conocimiento sobre intervenciones positivas complejas que combinen acciones sobre varios recursos personales (Hervás, 2017). Teniendo en cuenta esto, el estudio incluido en el capítulo 5 presenta un diseño combinado denominado programa "RP+", dirigido a desarrollar los recursos de capital psicológico, afrontamiento positivo del estrés, el uso de fortalezas personales en el trabajo y la atención plena o mindfulness (Ortega-Maldonado, Coo, y Salanova, 2016). Siguiendo una metodología innovadora e integradora, y en base a resultados de investigaciones anteriores, el programa integra el diseño de micro-intervención (Luthans, Avey, Avolio, Norman, y Combs, 2006) con pequeñas actividades favorecedoras de la práctica diaria y la transferencia a las tareas del puesto de trabajo. Con una duración de 5 semanas los diferentes recursos personales se trabajan de forma secuencial buscando un efecto reforzador de la intervención.

De forma general, los resultados de la aplicación de RP+ reflejan la efectividad del efecto reforzador de su diseño en el desarrollo de recursos, bienestar y desempeño. 
Además, estos resultados muestran la importancia de favorecer la transferencia a la actividad diaria de los nuevos comportamientos generados, para de esta forma lograr que los niveles de los recursos y resultados asociados (actitudes y comportamientos) se mantengan por encima de sus valores iniciales incluso un mes después de la intervención.

\section{La importancia de evaluar el proceso de implementación}

Por otro lado, el éxito de una intervención no depende sólo de su contenido y diseño, sino también de la calidad del proceso de implantación de la misma (Le Blanc y Oerlemans, 2016; Van Wingerden, 2016). Por ello, desde un punto de vista más pragmático, este trabajo doctoral aborda la importancia de tener en cuenta el denominado "error tipo III" a la hora de evaluar los efectos de un proceso de intervención (Randall, Griffiths, y Cox, 2005). Es decir, la importancia de tomar medidas para evitar concluir erróneamente que una intervención es inefectiva cuando es el proceso de implementación el que falla.

Las intervenciones para desarrollar recursos personales se aplican en un contexto en el que es necesario controlar numerables variables intervinientes que pueden afectar a los resultados. Entre estas variables aparecen las características cambiantes y diversas que rodean a las organizaciones, el diferente grado de implicación y compromiso de quienes participan, 0 incluso sus características personales (Lyubomirsky y Layous, 2013),. Por tanto, cabe mencionar que el proceso de evaluación de las intervenciones es una herramienta esencial para conocer de forma rigurosa su eficacia, pero a su vez es especialmente sensible a la influencia de estas terceras variables. Así, los diseños de investigación tradicionales que se aplican tanto en el ámbito de investigación como profesional, se basan en la medición de las variables intervenidas y los resultados positivos esperados, en momentos temporales anteriores y posteriores a la intervención, con la intención de comparar los datos y 
comprobar la existencia de los cambios esperados. Pero este tipo de diseños de evaluación no tienen en cuenta el control del denominado "error Tipo III" (Randall et al., 2005), lo que puede llevar a conclusiones erróneas sobre la efectividad de las intervenciones. Por ese motivo, en el estudio presentado en el capítulo 4 se realiza una evaluación del proceso de implementación de la intervención, mostrándose como herramienta para optimizar la calidad de la evaluación y poder determinar con precisión los efectos de la propia intervención. De hecho los resultados de la separación de quienes realmente practicaron diariamente con las actividades propuestas de quienes no lo hicieron, arrojan datos importantes sobre los efectos reales de dicha intervención.

\section{Desarrollo de recursos personales también en la etapa pre-profesional}

Por último, como también se indica en el capítulo inicial, la motivación de la presente tesis doctoral no reside únicamente en mejorar la vida de las personas que forman actualmente parte de las organizaciones, sino que también pretende estudiar cómo preparar adecuadamente a las personas que formarán parte de ellas en un futuro. En este sentido, los resultados obtenidos en el estudio incluido en el capítulo 4 también van dirigidos a quienes gestionan la formación de pre-profesionales, y quienes se dedican a su formación, aportando evidencia sobre cómo desarrollar recursos personales, bienestar psicológico y desempeño durante la etapa de formación superior.

Cuando una persona afronta sus estudios superiores necesita aprender conocimientos técnicos necesarios para realizar su labor futura, pero también necesita desarrollar otras capacidades y habilidades psicológicas relacionadas con la salud psicosocial, el desempeño, el compromiso e, incluso para contribuir a mejorar su empleabilidad (Fugate, Kinicki, y Ashforth, 2004). Las organizaciones educativas universitarias deben abordar esta necesidad y los resultados mostrados en la presente 
tesis doctoral pueden ser de utilidad para esta tarea. En este sentido se aporta una intervención basada en la evidencia dirigida a incrementar los recursos personales y el bienestar en pre-profesionales. Sin embargo, pese a ser un paso inicial en este tema de interés, será necesario en el futuro desarrollar investigación más profunda para profundizar en el conocimiento en esta área y poder aportar intervenciones sólidas basadas en la evidencia.

\section{Limitaciones y propuestas para futura investigación}

Los diferentes estudios presentados a lo largo de esta tesis doctoral poseen varias limitaciones a tener en cuenta a la hora de considerar sus principales hallazgos. En primer lugar, las muestras seleccionadas en los estudios de campo (capítulos 4 y 5) poseen un tamaño pequeño, lo que puede afectar tanto al grado de significación como a la potencia estadística. Sin embargo para muestras pequeñas se ha propuesto que no es tan determinante analizar el grado de significación como calcular el tamaño del efecto obtenido (Cumming, 2014; Faber y Fonseca, 2014). En ese sentido, los tamaños de los efectos obtenidos en el estudio 5 son satisfactorios y aportan solidez a los resultados de investigación. De hecho dichos tamaños del efecto son similares a otras investigaciones en intervenciones para desarrollar recursos personales (Bolier et al., 2013). Además, para completar los resultados cuantitativos, los estudios presentados en los capítulos 4 y 5 aportan análisis de información cualitativa, lo que sirve para mejorar la calidad de la evaluación de las intervenciones llevadas a cabo (Luthans y Youssef-Morgan, 2017; Reio y Werner, 2017).

Por otro lado, otra limitación de esta tesis doctoral es el foco exclusivo que pone en el desarrollo de recursos personales en lugar de investigar fenómenos grupales y organizacionales. Futura investigación podría ampliar el foco de investigación y contemplar el fenómeno de forma más global, ya que para lograr un buen nivel de bienestar psicológico en el trabajo, además de incrementar los recursos personales es 
necesario tanto reducir las demandas laborales como incrementar los recursos laborales (Richardson, 2017). Sin embargo, el incremento de recursos personales es una estrategia de fácil implementación en las organizaciones, por lo que hoy en día destaca entre la prácticas organizacionales dirigidas a mejorar la calidad de vida de la plantilla (Luthans y Youssef-Morgan, 2017).

Por último, esta tesis no analiza el posible efecto de algunas variables mediadoras y moderadoras del desarrollo de recursos personales, como pueden ser procesos cognitivos como los sesgos atencionales y confirmatorios (Williams, Kern, y Waters, 2016). La necesidad de profundizar en la investigación en este ámbito es una de las propuestas incluidas en el capítulo de revisión integrativa, por lo que esta tesis realiza una llamada a la futura investigación sobre ello.

\section{Unas palabras finales}

Incrementar la investigación sobre intervenciones es hoy en día más que nunca necesario para reducir la actual brecha existente entre la academia y los profesionales (Tkachenko, Hahn, y Peterson, 2017). Se trata de aportar soluciones sólidas y basadas en la evidencia a quienes se dedican a solucionar. Por tanto, se trata de ejercer la ciencia psicológica en su pura esencia: mejorar la vida de las personas ayudándoles a construir los recursos necesarios para su desarrollo profesional y personal. Si a algo de esto ha podido contribuir esta tesis, el objetivo se habrá logrado.

\section{Referencias}

Avey, J. B., Reichard, R. J., Luthans, F., \& Mhatre, K. H. (2011). Meta-analysis of the impact of positive psychological capital on employee attitudes, behaviors, and performance. Human Resource Development Quarterly, 22(2), 127-152. https://doi.org/10.1002/hrdq.20070 
Bolier, L., Haverman, M., Westerhof, G. J., Riper, H., Smit, F., \& Bohlmeijer, E. (2013). Positive psychology interventions: a meta-analysis of randomized controlled studies. BMC Public Health, 13(1), 119. https://doi.org/10.1186/1471-2458-13-119

Burke, L. A., \& Hutchins, H. M. (2007). Training transfer: An integrative literature review. Human Resource Development Review, 6(3), 263-296. https://doi.org/10.1177/1534484307303035

Cropanzano, R., \& Wright, T. A. (2001). A Review and Further Refinement of the Happy- Productive Worker Thesis. Consulting Psychology Journal, 53(3), 182199. https://doi.org/10.1037//106W087.53.3.182

Cumming, G. (2014). The New Statistics: Why and How. Psychological Science, 25(1), 7-29. https://doi.org/10.1177/0956797613504966

Dawkins, S., Martin, A., Scott, J., \& Sanderson, K. (2013). Building on the positives: A psychometric review and critical analysis of the construct of Psychological Capital. Journal of Occupational and Organizational Psychology, 86(3), 348-370. https://doi.org/10.1111/joop.12007

Dello Russo, S., \& Stoykova, P. (2015). Psychological Capital Intervention (PCI): A Replication and Extension. Human Resource Development Quarterly, 26(3), 329347. https://doi.org/10.1002/hrdq

Faber, J., \& Fonseca, L. M. (2014). How sample size influences research outcomes. Dental Press Journal of Orthodontics, 19(4), 27-29. https://doi.org/10.1590/21769451.19.4.027-029.ebo

Folkman, S. (2008). The case for positive emotions in the stress process. Anxiety, Stress, and Coping, 21(1), 3-14. https://doi.org/10.1080/10615800701740457 
Fredrickson, B. L. (2004). The broaden-and-build theory of positive emotions. Philosophical Transactions of the Royal Society of London. Series B, Biological Sciences, 359(1449), 1367-78. https://doi.org/10.1098/rstb.2004.1512

Fugate, M., Kinicki, A. J., \& Ashforth, B. E. (2004). Employability: A psycho-social construct, its dimensions, and applications. Journal of Vocational Behavior, 65(1), 14-38. https://doi.org/10.1016/j.jvb.2003.10.005

Garland, E. L., Kiken, L. G., Faurot, K., Palsson, O., \& Gaylord, S. A. (2017). Upward Spirals of Mindfulness and Reappraisal: Testing the Mindfulness-to-Meaning Theory with Autoregressive Latent Trajectory Modeling. Cognitive Therapy and Research, 41(3), 381-392. https://doi.org/10.1007/s10608-016-9768-y

Hervás, G. (2017). The limits of positive interventions. Papeles Del Psicologo, 38(1), 42-49. https://doi.org/10.23923/pap.psicol2017.2820

Hobfoll, S. E. (2002). Social and psychological resources and adaptation. Review of General Psychology, 6(4), 307-324. https://doi.org/10.1037/1089-2680.6.4.307

Lazarus, R. S. (2003). TARGET ARTICLE: Does the Positive Psychology Movement Have Legs? Psychological Inquiry, 14(2), 93-109. https://doi.org/10.1207/S15327965PLI1402_02

Lazarus, R. S. (2006). Emotions and interpersonal relationships: toward a personcentered conceptualization of emotions and coping. Journal of Personality, 74(1), 9-46. https://doi.org/10.1111/j.1467-6494.2005.00368.x

Le Blanc, P. M., \& Oerlemans, W. G. M. (2016). Amplition in the Workplace: Building a Sustainable Workforce Through Individual Positive Psychological Interventions. Psychologist Papers, 37(3), 185-191. 
Linley, P. A., Nielsen, K. M., Gillett, R., \& Biswas-Diener, R. (2010). Using signature strengths in pursuit of goals: Effects on goal progress, need satisfaction, and wellbeing, and implications for coaching psychologists. International Coaching Psychology Review. https://doi.org/10.1017/CBO9781107415324.004

Litchfield, P., Cooper, C., Hancock, C., \& Watt, P. (2016). Work and wellbeing in the 21st century. International Journal of Environmental Research and Public Health, 13(11). https://doi.org/10.3390/ijerph13111065

Luthans, F., Avey, J. B., Avolio, B. J., Norman, S. M., \& Combs, G. M. (2006). Psychological capital development: toward a micro-intervention. Journal of Organizational Behavior, 27, 387-393.

Luthans, F., \& Youssef-Morgan, C. M. (2017). Psychological Capital: An EvidenceBased Positive Approach. Annual Review of Organizational Psychology and Organizational Behavior, 4(1), 339-366. https://doi.org/10.1146/annurevorgpsych-032516-113324

Luthans, F., Youssef-Morgan, C. M., \& Avolio, B. J. (2015). Psychological Capital and Beyond. New York: Oxford University Press.

Lyubomirsky, S., \& Layous, K. (2013). How Do Simple Positive Activities Increase WellBeing? Current Directions in Psychological Science, 22(1), 57-62. https://doi.org/10.1177/0963721412469809

Moskowitz, J. T., Carrico, A. W., Duncan, L. G., Cohn, M. A., Cheung, E. O., Batchelder, A., ... Folkman, S. (2017). Randomized controlled trial of a positive affect intervention for people newly diagnosed with HIV. Journal of Consulting and Clinical Psychology, 85(5), 409-423. https://doi.org/10.1037/ccp0000188 
Newman, A., Ucbasaran, D., Zhu, F., \& Hirst, G. (2014). Psychological capital: A review and synthesis. Journal of Organizational Behavior, 25, S120-S138. https://doi.org/10.1002/job.1916

Nielsen, K., Nielsen, M. B., Ogbonnaya, C., Känsälä, M., Saari, E., \& Isaksson, K. (2017). Workplace resources to improve both employee well-being and performance: A systematic review and meta-analysis. Work and Stress, 31(2), 101-120. https://doi.org/10.1080/02678373.2017.1304463

Ortega-Maldonado, A., Coo, C., \& Salanova, M. (2016). “ RP + ": Desarrollo del Capital Psicológico en un programa para el incremento del Bienestar y la Excelencia. Capital Humano, 135, 73-75.

Parks, A. C., \& Biswas-Diener, R. (2013). Positive intervention: Past, present, future. Mindfulness, Acceptance, and Positive Psychology: The Seven Foundations for Wellbeing, (330), 140-165.

Randall, R., Griffiths, A., \& Cox, T. (2005). Evaluating organizational stressmanagement interventions using adapted study designs. European Journal of Work and Organizational Psychology, 14(1), 23-41. https://doi.org/10.1080/13594320444000209

Reio, T. G., \& Werner, J. M. (2017). Publishing Mixed Methods Research: Thoughts and Recommendations Concerning Rigor. Human Resource Development Quarterly, 28(4), 439-449. https://doi.org/10.1002/hrdq.21291

Richardson, K. M. (2017). Managing employee stress and wellness in the new millennium. Journal of Occupational Health Psychology, 22(3), 423-428. https://doi.org/10.1037/ocp0000066 
Salanova, M., Llorens, S., \& Schaufeli, W. B. (2011). "Yes, I Can, I Feel Good, and I Just Do It!" On Gain Cycles and Spirals of Efficacy Beliefs, Affect, and Engagement. Applied Psychology, 60(2), 255-285. https://doi.org/10.1111/j.14640597.2010.00435.x

Seligman, M. E. P. (2011). Flourish. Spring, 80-87. https://doi.org/10.1037/0003066X.61.8.772

Tkachenko, O., Hahn, H.-J., \& Peterson, S. L. (2017). Research-Practice Gap in Applied Fields: An Integrative Literature Review. Human Resource Development Review, 16(3), 235-262. https://doi.org/10.1177/1534484317707562

Van Wingerden, J. (2016). Job Demands-Resources Interventions. Erasmus Universiteit Rotterdam. https://doi.org/10.13140/RG.2.1.1956.7603

Williams, P., Kern, M. L., \& Waters, L. (2016). Exploring selective exposure and confirmation bias as processes underlying employee work happiness: An $\begin{array}{llllll}\text { intervention study. Frontiers in Psychology, } & 7(\mathrm{JUN}), & 878 .\end{array}$ https://doi.org/10.3389/fpsyg.2016.00878

Youssef-Morgan, C. M. (2014). Advancing OB Research: An Illustration Using Psychological Capital. Journal of Leadership \& Organizational Studies, 21(2), 130-140. https://doi.org/10.1177/1548051813515512 


\section{Chapter 6: General conclusions (English)}

As mentioned in the introduction (chapter 1), this dissertation aims to enhance the scientific knowledge about positive psychological interventions (PPI) for developing personal resources at work. For this purpose, two research questions are raised: Is the efficacy of positive psychological interventions for developing personal resources at work confirmed? What positive results does the development of personal resources through positive psychological interventions achieve? Additionally, two research questions are raised to investigate how to optimize these interventions: Is combining the development of different personal resources through an intervention a good strategy to optimize efficacy? Is the training transfer from interventions for personal resource development a good strategy to obtain sustainability?

To address these research questions, this dissertation is composed of four studies with professional and pre-professional samples. First, chapter 2 presents an integrative review of the literature about interventions on a widely investigated personal resource at work: psychological capital (PsyCap). This integrative review sheds light on the efficacy of psychological capital interventions in terms of the development of personal resources and the related increase in psychological wellbeing and performance. Specifically, this integrative review analyses several intervention procedures conducted on professional and pre-professional samples from different organizations in diverse countries, economic activities, and sectors. For this purpose, this integrative review compares the effectiveness and results revealed by the literature, and it summarizes the main conclusions. Finally, this integrative review reports on the cognitive mechanisms shared by PsyCap and another personal resource highly involved in psychological wellbeing and work performance: meaning-focused coping (MFC). The review concludes and hypothesises that these two personal resources may be linked by the adaptive and synergetic mechanism of positive reframing of adversity. 
Based on this finding, chapter 3 presents a longitudinal study of PsyCap, meaning-focused coping, satisfaction (as a psychological wellbeing measure), and performance, conducted in the academic context. The study findings shed light on the theoretical relationship between the two personal resources, and they empirically support the predictive effect of PsyCap and meaning-focused coping on both psychological wellbeing and performance. The study findings provide theoretical and empirical support for combining the development of several personal resources as a strategy to optimize positive interventions at work. For this reason, chapter 4 and 5 continue the research presented up to this point, and they present two field studies on professional and pre-professional samples to evaluate the intervention effects when several personal resources are developed together. These two studies evaluate different intervention procedures using different experimental conditions, waiting lists, and control groups, contributing to the research on procedure-individual-contextefficacy relationships. In addition, these two studies evaluate the training transfer to daily work life with the aim of investigating how to obtain the sustainability of the intervention effects.

As explained from the beginning of the present dissertation, this thesis addresses individual processes within group and organizational dynamics. Due to the complexity of the phenomenon, a large number of variables are analysed in an extensive, comprehensive, and convergent multivariate focus. Thus, this dissertation adopts a mixed-methods approach to analyse both quantitative and qualitative data, using a wide range of analytical strategies to obtain the most complete information. At the quantitative level, path analysis, mean differences ( $t$ test, ANOVA, MANOVA, and ANCOVA), and general linear models are used. At the qualitative level, content analysis of information from different sources, such as self-reported written evaluations or brief interviews, is used. In addition, the analytical strategies address cognitive, 
behavioural, and affective processes, in order to investigate this complex phenomenon in a 360-degree evaluation.

For a more comprehensive view, the general conclusions and main findings of this dissertation are summarized in figure 1 . The next sections present the main theoretical and practical implications. Finally the research limitations and related future research proposals are presented.

Figure 1. Integrated model with main findings.

\section{INTERVENTIONS THAT COMBINE PERSONAL RESOURCES DEVELOPMENT}

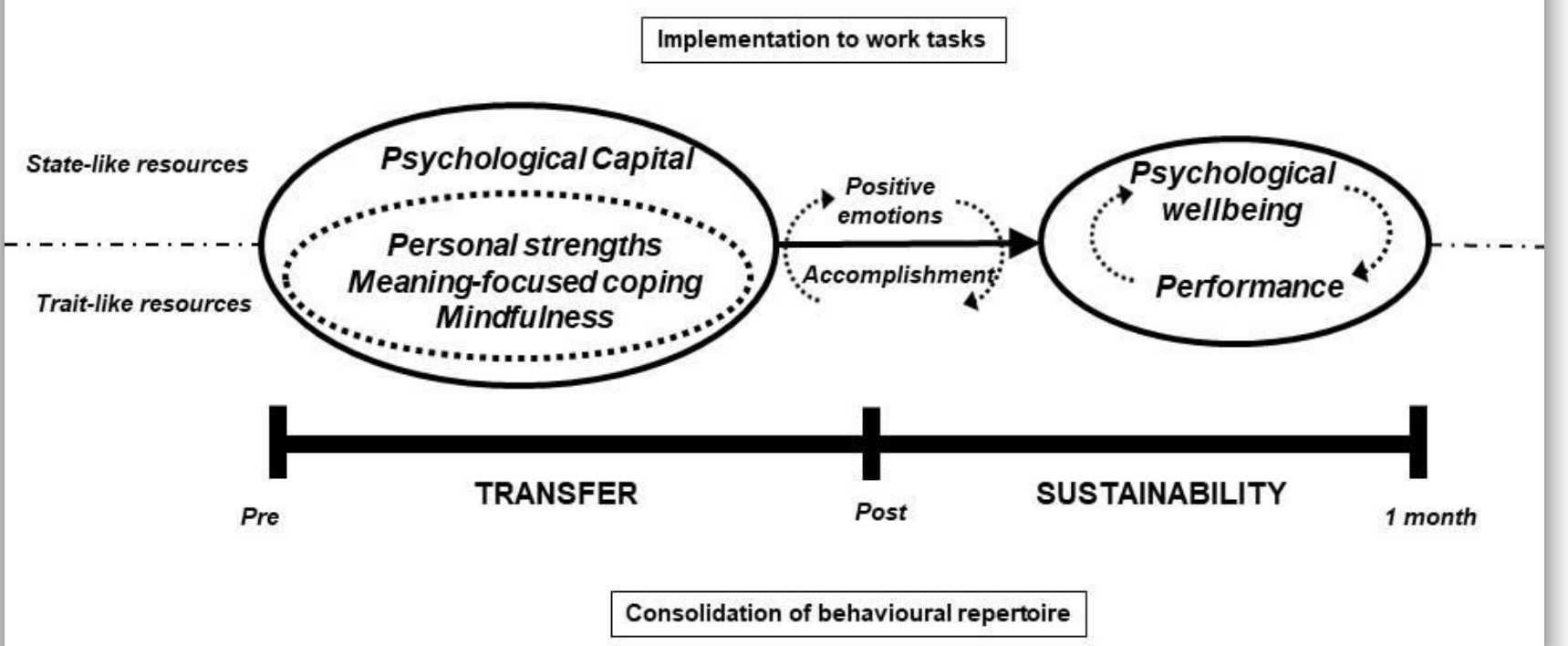

\section{Main theoretical implications and contributions}

As discussed in the introduction, the main findings of this thesis provide evidence about PPI for personal resource development, psychological wellbeing, and performance. This information would be useful for Positive Organizational Psychology and Positive Organizational Behaviour researchers. A synthesis of the main findings of this thesis reveals that the personal resources investigated (psychological capital, meaning-focused coping, and mindfulness) show a predictive relationship with 
desirable outcomes in terms of psychological wellbeing and performance. Specifically, this dissertation provides relevant information about the relationship between psychological capital and meaning-focused coping. At a theoretical level, this dissertation argues that these two personal resources are linked, and it suggests that they may be sharing some psychological mechanisms, mainly the positive reappraisal of adversities mechanism (Avey, Reichard, Luthans, \& Mhatre, 2011; Dawkins, Martin, Scott, \& Sanderson, 2013; Luthans \& Youssef-Morgan, 2017; Youssef-Morgan, 2014). In this regard, the findings of the studies presented in this dissertation show the capacity of positive reframing as an adaptive and effective strategy for improving accomplishment at work and being successful at accomplishing tasks and goals through perseverance and intrinsic motivation.

In addition to this relationship between PsyCap and MFC, these personal resources are also linked to mindfulness in the studies that make up this dissertation. Thus, the development of the mindfulness ability seems to be related to the capacity to positively reframe adversity through a broader and more flexible state of consciousness that allows greater acceptance of setbacks. Thus, both of the meaning-focused coping strategies (acceptance and positive reframing) emerge as key mechanisms in contextual appraisals of problems (Folkman, 2008), and they allow a better and more favourable interpretation of adversity (Garland, Kiken, Faurot, Palsson, \& Gaylord, 2017). This capacity to cognitively transform the meaning of a problem from a threat to a challenge allows individuals to be positioned in a new behavioural and affective scenario, where, through resilience and the use of personal strengths, it is possible to create a more adaptive behavioural repertoire that elicits psychological wellbeing and accomplishment, even when the context is unfavourable (Folkman, 2008; Fredrickson, 2004; Luthans, Youssef-Morgan, \& Avolio, 2015). 


\section{Growing through adversity: the contribution of Positive Psychology to the management of negative situations}

From the beginning, Positive Psychology research has focused on increasing positive emotions and diminishing negative emotions as a key factor in improving happiness and flourishing (Seligman, 2011). However, this approach has been criticised because it neglects the role of the inherent unfavourable and traumatic events in life and the negative emotions associated with them (Lazarus, 2003). However, considering acceptance as a good adaptive strategy when problems and adversities arise may emerge as a new approach to the role of negative emotions in psychological wellbeing, which suggests that managing negative emotions through acceptance may be a successful cognitive-affective strategy for flourishing, even when life's circumstances are unfavourable. Acceptance is proposed as an adaptive mechanism for understanding the world as a possible hostile environment, helping people to understand their negative emotions and approve and recognise them as a natural and transformational element in their lives (Lazarus, 2006). This adaptive management of negative emotions may contribute to reformulating the affective paradigm in Positive Psychology. This new approach provided by this dissertation suggests that fulfilment is reached through PPI designed to increase personal strengths and promote opportunities (Parks \& Biswas-Diener, 2013), but it also suggests that fulfilment may be reached through PPI oriented toward transforming setbacks into opportunities (Moskowitz et al., 2017) within a positive approach to stress management (Richardson, 2017).

\section{Combining resources to obtain virtuous spirals}

Furthermore, the synergetic and interactive mechanisms shared by the personal resources investigated in this thesis are based on the generation of virtuous spirals (Salanova, Llorens, \& Schaufeli, 2011) (see figure 1). Thus, combined personal 
resource development through interventions may increase the individual's repertory of resources and generate positive emotions, which may contribute to enhancing and consolidating his/her personal resources in a virtuous spiral (Fredrickson, 2004; Hobfoll, 2002; Luthans \& Youssef-Morgan, 2017). As figure 1 shows, this dissertation proposes that the virtuous spiral through interactions among resources involves both state-like resources (less stable and closely linked to work task achievement) and the trait-like resources (more stable and closely linked to personal growth). The findings of this dissertation suggest that PsyCap is a state-like personal resource that may promote trait-like personal resource development through specific mechanisms, which, in turn, may promote employee fulfilment at work (Newman, Ucbasaran, Zhu, \& Hirst, 2014; Youssef-Morgan, 2014).

Regarding these underlying mechanisms, the four PsyCap components (selfefficacy, optimism, hope, and resilience) have been found to interact together, conforming a higher-order construct, but they can also predict desirable attitudes, behaviours, and outcomes on their own (Luthans \& Youssef-Morgan, 2017). In other words, the four PsyCap components predict psychological wellbeing and work performance in conjunction, but they also predict them separately. Furthermore, based on the definition of each PsyCap component, it is possible to suggest the relevance of each of these personal resources in linking psychological capital to more stable (traitlike) resources, such as mindfulness and meaning-focused coping. Moreover, another finding from this dissertation is the different pattern of growth found in the development of each PsyCap component through the interventions conducted. Thus, this dissertation contributes to PsyCap research by addressing the call to investigate PsyCap components separately (Youssef-Morgan, 2014). Nevertheless, further research is needed to investigate how the different patterns of development of each PsyCap component may affect the development of different trait-like resources, and how they can influence psychological wellbeing and work performance. 
In summary, from a theoretical perspective, the dissertation findings contribute to the PPI research by proposing combined personal resource development as an organizational strategy to promote psychological wellbeing and work performance. These empirical findings shed light on how to optimize positive interventions designed to promote happy and productive workers (Cropanzano \& Wright, 2001).

\section{Main practical implications and contributions}

Currently, the link between psychological wellbeing and work performance is of great interest to researchers and professionals (Litchfield, Cooper, Hancock, \& Watt, 2016; Nielsen et al., 2017). As mentioned in the introduction (chapter 1), the findings of this dissertation should be useful for both applied researchers and practitioners on Organizational Positive Psychology and Positive Organizational Behaviour. Therefore, this dissertation presents evidence-based interventions for developing personal resources at work and increasing psychological wellbeing and work performance.

Moreover, this dissertation reports on how to optimize these evidenced-based positive intervention procedures. Two strategies are evaluated: combining the development of different personal resources, and transferring training to daily work life. Generally, the interventions presented in chapters 4 and 5 show that the combination of personal resource development and training transfer positively affects the interventions' sustainability, at least at a one month follow-up. Thus, the study presented in chapter 4 shows that combining the development of PsyCap and meaning-focused coping (based on acceptance and positive reframing) is a more effective strategy for increasing participants' PsyCap levels, as well as for increasing their levels of psychological wellbeing. Furthermore, this positive effect remains one month after the intervention. Particularly, this sustainability appears when daily practice to promote training transfer is added to the intervention design, which helps participants to consolidate the new behavioural repertory acquired through 
achievement and positive affect (Burke \& Hutchins, 2007; Fredrickson, 2004; Hobfoll, 2002; Linley, Nielsen, Gillett, \& Biswas-Diener, 2010; Seligman, 2011).

Evaluating the long-term effects of interventions aimed at developing personal resources is necessary and useful because it may influence practitioners' and managers' decisions to invest in developmental activities in organizations (Dello Russo \& Stoykova, 2015; Youssef-Morgan, 2014). However, achieving training transfer to daily work life is also important for obtaining the sustainability of the development linked to the intervention (Burke \& Hutchins, 2007; Luthans \& Youssef-Morgan, 2017). Summarizing, the main findings of the present dissertation address researchers' and practitioners' need to optimize positive interventions at work.

\section{""RP +": a program that adds the development of more personal resources}

As mentioned throughout this dissertation, obtaining broader but sustainable development is currently an important challenge for Human Resource Development researchers and practitioners (Le Blanc \& Oerlemans, 2016). In this challenge, a strategy for optimizing PPI efficacy is necessary in order to enhance the knowledge about complex positive interventions that combine actions on various personal resources (Hervás, 2017). Based on this idea, the study presented in chapter 5 evaluates a combined intervention design called "RP+", aimed at developing the personal resources of psychological capital, meaning-focused coping, the use of strengths at work, and mindfulness (Ortega-Maldonado, Coo, \& Salanova, 2016). Through an integrative and innovative methodology, and drawing on previous research, this programme consists of five micro-interventions (Luthans, Avey, Avolio, Norman, \& Combs, 2006) for developing personal resources at work, and it also adds brief activities for promoting daily practice and training transfer to daily work tasks. The 
programme is designed through a sequential reinforcement effect of the personal resources developed in five weeks.

Generally, the study findings confirm the efficacy of the RP+ reinforcement-based design for increasing participants' levels of personal resources, psychological wellbeing, and performance. Moreover, these findings provide information about the importance of training transfer for obtaining the sustainability of the intervention effects (attitudes, behaviours, and desirable outcomes) at a one-month follow-up.

\section{The importance of evaluating the implementation process}

In addition, the success of an intervention not only depends on its content or its design, but also on the quality of the implementation process (Le Blanc \& Oerlemans, 2016; Van Wingerden, 2016). Therefore, from a more pragmatic point of view, this dissertation addresses the importance of considering the so-called "Type III error" when an intervention is evaluated (Randall, Griffiths, \& Cox, 2005). That is, it is important to avoid the erroneous conclusion that an intervention is ineffective, when the implementation process is really what fails.

PPI to develop personal resources are applied in multivariate contexts where it is necessary to control numerous variables that may negatively affect the results. Among these variables are the unstable and diverse characteristics of organizations, the different implication levels of participants, or even their personality characteristics (Lyubomirsky \& Layous, 2013). Therefore, it is worthwhile to consider that the intervention evaluation process is an essential tool to rigorously measure their efficacy. Likewise it is worth considering that the evaluation process is especially sensitive to being influenced by these external and threatening variables. Thus, traditional research designs that are applied by researchers and practitioners are based on comparing pre and post measures of the variables, as well as the desirable related positive outcomes, in order to know whether the expected changes occurred. However, this type of 
evaluation design does not take into account the control of the so-called "Type III error" (Randall et al., 2005), which may lead to erroneous conclusions about the intervention's efficacy. For this reason, the study presented in chapter 4 evaluates the implementation process of the intervention conducted, as a tool to optimize the quality of the evaluation and draw correct conclusions about its efficacy. In this regard, participants who actually practiced the proposed activities daily were compared to those who did not, and the results shed light on the real effects of the implemented intervention.

\section{Development of personal resources for pre-professionals}

Finally, as indicated in the introduction (chapter 1), this dissertation aims not only to improve current workers' lives, but also to investigate how to correctly develop the future workforce. Thus, the findings presented in chapter 4 are also interesting for higher education managers and teachers because this study provides evidence about developing personal resources, psychological wellbeing, and performance in higher education.

Completing a degree marks an important turning point in life. We need to learn about technical skills that will be necessary for performing future professional work, and develop other psychological capacities and abilities linked to psychosocial health, performance, and commitment, and even related to improving employability (Fugate, Kinicki, \& Ashforth, 2004). Higher education institutions should be concerned about developing personal resources in their students. The findings presented in this dissertation may be useful to them because an evidenced-based intervention for developing personal resources and psychological well-being in pre-professionals is evaluated. However, these findings are an initial step in increasing the knowledge on evidence-based PPI for developing pre-professionals' personal resources, psychological wellbeing, and performance, and further research is necessary. 


\section{Limitations and further research proposals}

The findings from the four studies presented in this dissertation have some limitations that have to be taken into account in the interpretation of the results. First, the sample size of the two field studies (chapter 4 and 5) is small, which may affect both statistical significance and power. However, it has been proposed that for small samples, obtaining large effect sizes is more determinant than significance (Cumming, 2014; Faber \& Fonseca, 2014). Thus, the effect sizes obtained in the study presented in chapter 5 are satisfactory and confirm the robustness of the study findings. In fact, the effect sizes found are similar to those found in other positive interventions for developing personal resources (Bolier et al., 2013). Furthermore, to complete the quantitative results, the studies presented in chapters 4 and 5 report qualitative data, which is related to optimizing the quality of the intervention assessments (Luthans \& Youssef-Morgan, 2017; Reio \& Werner, 2017).

On the other hand, another limitation of this dissertation is related to its exclusive focus on the development of personal resources instead of group and organizational phenomena. Future research could broaden the research focus by investigating the phenomena more globally because, in order to achieve a good level of psychological well-being at work, it is necessary to increase personal resources, but it is also necessary to reduce job demands and increase job resources (Richardson, 2017). However, increasing personal resources is an feasible strategy to implement in organizations, and it is currently a widely utilized organizational practice to improve the quality of life of the workforce (Luthans \& Youssef-Morgan, 2017).

Finally, this dissertation is not focused on analysing the mediating and moderating effects of some variables in the personal resource development process, such as cognitive processes, selective exposures, and confirmation bias (Williams, Kern, \& Waters, 2016). In addition, the importance of further research in this area is included in 
the future agenda proposed in the integrative review (chapter 2), and so this dissertation calls for further research on this topic.

\section{Some final words}

Enhancing the research on interventions is more necessary than ever in order to reduce the existing research-practice gap (Tkachenko, Hahn, \& Peterson, 2017). It involves providing solid and evidence-based solutions to those who are dedicated to solving daily problems in organizations. Therefore, it is about engaging in psychological science in its pure form: improving people's lives by helping them to build the necessary resources for their professional and personal development. If this dissertation contributes to this, its goal will be reached.

\section{References}

Avey, J. B., Reichard, R. J., Luthans, F., \& Mhatre, K. H. (2011). Meta-analysis of the impact of positive psychological capital on employee attitudes, behaviors, and performance. Human Resource Development Quarterly, 22(2), 127-152. https://doi.org/10.1002/hrdq.20070

Bolier, L., Haverman, M., Westerhof, G. J., Riper, H., Smit, F., \& Bohlmeijer, E. (2013). Positive psychology interventions: a meta-analysis of randomized controlled studies. BMC Public Health, 13(1), 119. https://doi.org/10.1186/1471-2458-13-119

Burke, L. A., \& Hutchins, H. M. (2007). Training transfer: An integrative literature review. Human Resource Development Review, 6(3), 263-296. https://doi.org/10.1177/1534484307303035

Cropanzano, R., \& Wright, T. A. (2001). A Review and Further Refinement of the Happy- Productive Worker Thesis. Consulting Psychology Journal, 53(3), 182199. https://doi.org/10.1037//106W087.53.3.182 
Cumming, G. (2014). The New Statistics: Why and How. Psychological Science, 25(1), 7-29. https://doi.org/10.1177/0956797613504966

Dawkins, S., Martin, A., Scott, J., \& Sanderson, K. (2013). Building on the positives: A psychometric review and critical analysis of the construct of Psychological Capital. Journal of Occupational and Organizational Psychology, 86(3), 348-370. https://doi.org/10.1111/joop.12007

Dello Russo, S., \& Stoykova, P. (2015). Psychological Capital Intervention (PCI): A Replication and Extension. Human Resource Development Quarterly, 26(3), 329347. https://doi.org/10.1002/hrdq

Faber, J., \& Fonseca, L. M. (2014). How sample size influences research outcomes. Dental Press Journal of Orthodontics, 19(4), 27-29. https://doi.org/10.1590/21769451.19.4.027-029.ebo

Folkman, S. (2008). The case for positive emotions in the stress process. Anxiety, Stress, and Coping, 21(1), 3-14. https://doi.org/10.1080/10615800701740457

Fredrickson, B. L. (2004). The broaden-and-build theory of positive emotions. Philosophical Transactions of the Royal Society of London. Series B, Biological Sciences, 359(1449), 1367-78. https://doi.org/10.1098/rstb.2004.1512

Fugate, M., Kinicki, A. J., \& Ashforth, B. E. (2004). Employability: A psycho-social construct, its dimensions, and applications. Journal of Vocational Behavior, 65(1), 14-38. https://doi.org/10.1016/j.jvb.2003.10.005

Garland, E. L., Kiken, L. G., Faurot, K., Palsson, O., \& Gaylord, S. A. (2017). Upward Spirals of Mindfulness and Reappraisal: Testing the Mindfulness-to-Meaning Theory with Autoregressive Latent Trajectory Modeling. Cognitive Therapy and Research, 41(3), 381-392. https://doi.org/10.1007/s10608-016-9768-y 
Hervás, G. (2017). The limits of positive interventions. Papeles Del Psicologo, 38(1), 42-49. https://doi.org/10.23923/pap.psicol2017.2820

Hobfoll, S. E. (2002). Social and psychological resources and adaptation. Review of General Psychology, 6(4), 307-324. https://doi.org/10.1037/1089-2680.6.4.307

Lazarus, R. S. (2003). TARGET ARTICLE: Does the Positive Psychology Movement Have Legs? Psychological Inquiry, 14(2), 93-109. https://doi.org/10.1207/S15327965PLI1402_02

Lazarus, R. S. (2006). Emotions and interpersonal relationships: toward a personcentered conceptualization of emotions and coping. Journal of Personality, 74(1), 9-46. https://doi.org/10.1111/j.1467-6494.2005.00368.x

Le Blanc, P. M., \& Oerlemans, W. G. M. (2016). Amplition in the Workplace: Building a Sustainable Workforce Through Individual Positive Psychological Interventions. Psychologist Papers, 37(3), 185-191.

Linley, P. A., Nielsen, K. M., Gillett, R., \& Biswas-Diener, R. (2010). Using signature strengths in pursuit of goals: Effects on goal progress, need satisfaction, and wellbeing, and implications for coaching psychologists. International Coaching Psychology Review. https://doi.org/10.1017/CBO9781107415324.004

Litchfield, P., Cooper, C., Hancock, C., \& Watt, P. (2016). Work and wellbeing in the 21st century. International Journal of Environmental Research and Public Health, 13(11). https://doi.org/10.3390/ijerph13111065

Luthans, F., Avey, J. B., Avolio, B. J., Norman, S. M., \& Combs, G. M. (2006). Psychological capital development: toward a micro-intervention. Journal of Organizational Behavior, 27, 387-393. 
Luthans, F., \& Youssef-Morgan, C. M. (2017). Psychological Capital: An EvidenceBased Positive Approach. Annual Review of Organizational Psychology and Organizational Behavior, 4(1), 339-366. https://doi.org/10.1146/annurevorgpsych-032516-113324

Luthans, F., Youssef-Morgan, C. M., \& Avolio, B. J. (2015). Psychological Capital and Beyond. New York: Oxford University Press.

Lyubomirsky, S., \& Layous, K. (2013). How Do Simple Positive Activities Increase WellBeing? Current Directions in Psychological Science, 22(1), 57-62. https://doi.org/10.1177/0963721412469809

Moskowitz, J. T., Carrico, A. W., Duncan, L. G., Cohn, M. A., Cheung, E. O., Batchelder, A., ... Folkman, S. (2017). Randomized controlled trial of a positive affect intervention for people newly diagnosed with HIV. Journal of Consulting and Clinical Psychology, 85(5), 409-423. https://doi.org/10.1037/ccp0000188

Newman, A., Ucbasaran, D., Zhu, F., \& Hirst, G. (2014). Psychological capital: A review and synthesis. Journal of Organizational Behavior, 25, S120-S138. https://doi.org/10.1002/job.1916

Nielsen, K., Nielsen, M. B., Ogbonnaya, C., Känsälä, M., Saari, E., \& Isaksson, K. (2017). Workplace resources to improve both employee well-being and performance: A systematic review and meta-analysis. Work and Stress, 31(2), 101-120. https://doi.org/10.1080/02678373.2017.1304463

Ortega-Maldonado, A., Coo, C., \& Salanova, M. (2016). “ RP + ”: Desarrollo del Capital Psicológico en un programa para el incremento del Bienestar y la Excelencia. Capital Humano, 135, 73-75. 
Parks, A. C., \& Biswas-Diener, R. (2013). Positive intervention: Past, present, future. Mindfulness, Acceptance, and Positive Psychology: The Seven Foundations for Wellbeing, (330), 140-165.

Randall, R., Griffiths, A., \& Cox, T. (2005). Evaluating organizational stressmanagement interventions using adapted study designs. European Journal of Work and Organizational Psychology, 14(1), 23-41. https://doi.org/10.1080/13594320444000209

Reio, T. G., \& Werner, J. M. (2017). Publishing Mixed Methods Research: Thoughts and Recommendations Concerning Rigor. Human Resource Development Quarterly, 28(4), 439-449. https://doi.org/10.1002/hrdq.21291

Richardson, K. M. (2017). Managing employee stress and wellness in the new millennium. Journal of Occupational Health Psychology, 22(3), 423-428. https://doi.org/10.1037/ocp0000066

Salanova, M., Llorens, S., \& Schaufeli, W. B. (2011). "Yes, I Can, I Feel Good, and I Just Do It!" On Gain Cycles and Spirals of Efficacy Beliefs, Affect, and Engagement. Applied Psychology, 60(2), 255-285. https://doi.org/10.1111/j.14640597.2010.00435.x

Seligman, M. E. P. (2011). Flourish. Spring, 80-87. https://doi.org/10.1037/0003066X.61.8.772

Tkachenko, O., Hahn, H.-J., \& Peterson, S. L. (2017). Research-Practice Gap in Applied Fields: An Integrative Literature Review. Human Resource Development Review, 16(3), 235-262. https://doi.org/10.1177/1534484317707562

Van Wingerden, J. (2016). Job Demands-Resources Interventions. Erasmus Universiteit Rotterdam. https://doi.org/10.13140/RG.2.1.1956.7603 
Williams, P., Kern, M. L., \& Waters, L. (2016). Exploring selective exposure and confirmation bias as processes underlying employee work happiness: An

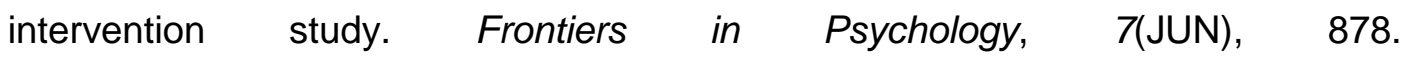
https://doi.org/10.3389/fpsyg.2016.00878

Youssef-Morgan, C. M. (2014). Advancing OB Research: An Illustration Using Psychological Capital. Journal of Leadership \& Organizational Studies, 21(2), 130-140. https://doi.org/10.1177/1548051813515512 


\section{Agradecimientos}

Esta es la historia de un barco que ha podido cumplir su exitosa travesía gracias al trabajo y colaboración de muchas personas:

La Doctora Marisa Salanova, una capitana y timonel transformacional. Inspiradora, respetuosa, leal y generosa. Un gran orgullo poder haber sido su discípulo.

Mis WANTers del universo. Una tripulación dispuesta si es necesario a limpiar cubiertas, arreglar tablones, izar y plegar velas, lidiar con grandes tormentas, e incluso a luchar contra piratas y corsarios. Camaradas de quien aprender y con quien beber buen ron al llegar a puerto. Un privilegio convivir con personas así.

Mis compañeras y compañeros del Posgrado de Psicología Positiva Aplicada. Personas increíbles dispuestas siempre a compartir el mapa del tesoro. En nuestro recuerdo siempre quedará ese increíble año.

Mi familia de sangre y mi familia de vida. Se ocupan de la concina para que nunca falten los víveres y revisan la intendencia para que siempre haya munición.

El Doctor Israel Sánchez-Cardona. El mejor polizón que pudo tener mi barco.

Castellón de la Plana, puerto de partida y llegada de este viaje.

Norwich y San Juan, puertos de parada y repostaje.

Las Doctoras Karina Nielsen y Ana Sanz-Vergel, me regalaron una brújula y un catalejo en el momento adecuado del viaje.

A Laura, la verdadera ancla donde se amarra mi barco para no ir a la deriva.

A todas y a todos, simplemente gracias. 